\title{
A DIFERENÇA DOS SEXOS: LACAN E O FEMINISMO
}

(versão original)

Tese apresentada ao Instituto de Psicologia da Universidade de São Paulo, como parte dos requisitos para obtenção do grau de Doutor em Psicologia.

Área de concentração: Psicologia Clínica

Orientador: Christian Ingo Lenz Dunker 
AUTORIZO A REPRODUÇÃO E DIVULGAÇÃO TOTAL OU PARCIAL DESTE TRABALHO, POR QUALQUER MEIO CONVENCIONAL OU ELETRÔNICO, PARA FINS DE ESTUDO E PESQUISA, DESDE QUE CITADA A FONTE.

Catalogação na publicação

Biblioteca Dante Moreira Leite

Instituto de Psicologia da Universidade de São Paulo

Cossi, Rafael Kalaf.

A diferença dos sexos: Lacan e o feminismo / Rafael Kalaf Cossi; orientador Christian Ingo Lenz Dunker. -- São Paulo, 2016.

$276 \mathrm{f}$.

Tese (Doutorado - Programa de Pós-Graduação em Psicologia. Área de Concentração: Psicologia Clínica) - Instituto de Psicologia da Universidade de São Paulo.

1. Diferença dos sexos 2. Psicanálise 3. Feminismo 4. Gênero 5. Sexuação I. Título.

BF692.2 


\section{FOLHA DE APROVAÇÃO}

Nome: Cossi, R. K.

Título: A diferença dos sexos: Lacan e o feminismo

Tese apresentada ao Instituto de Psicologia da Universidade de São Paulo para obtenção do título de Doutor em Psicologia

Aprovado em:

Banca Examinadora

Prof. Dr.

Instituição: Assinatura:

Prof. Dr.

Instituição: Assinatura:

Prof. Dr.

Instituição: Assinatura:

Prof. Dr.

Instituição: Assinatura:

Prof. Dr.

Instituição: Assinatura: 
Para Márcio Cossi, pela força. 


\section{AGRADECIMENTOS}

Agradeço ao amigo e professor Christian Dunker pela orientação entusiasmada e criativa, pela leitura rigorosa. Sobretudo pela presença constante, pela parceria e pela confiança.

A Cristina Lindenmeyer, supervisora que prontamente me recebeu na Paris 7.

A Patrícia Porchat e Maria Josefina Sota Fuentes, pelas vigorosas pontuações no exame da qualificação e enriquecimento da pesquisa.

Aos colegas de grupo de orientação, do qual tenho orgulho de ter participado - Maria Letícia Reis, Daniele Sanches, Clarice Paulon, Luciana Salum, Hugo Lana, Beto Propheta, Marcus Teshainer, João Domiciano, Dulce Coppedê, Rafael Lima, Jaqueline Cardoso, Renata Bazzo, Rafael Franco, Lígia Borba, Karen Alves, Clóvis Zanetti, Natalie Mas, Mayla Di Martino, Priscila Santos - , pelo interesse, pelas contribuições e pelos bons encontros.

Ao comparsa Pedro Ambra, pelas trocas e pela ajuda na França. A Paulo Beer, pelo auxílio nos trâmites fapespianos. A Paulo Sérgio de Souza Jr., pela revisão cuidadosa.

A Ana Cláudia Fossen e Bianca Boreggio, companheiras da causa jundiaiense.

Aos meus necessários irmãos Renato e Paula, minha mãe Rosana, tio Du e meus avós Vitor, Aracy, Herval e Nêmesis.

Às queridas Karina Belloni e Sílmia Sobreira, que acompanharam tudo de perto.

Aos funcionários da secretaria do Departamento de Psicologia Clínica, da Secretaria de Pós-graduação e da Biblioteca do Instituto de Psicologia, sempre generosos.

A Michele, em todos os registros.

À FAPESP, pela concessão da bolsa, pelo parecerista atento e pelas preciosas oportunidades no exterior. 
Um homem e uma mulher podem se ouvir, não digo que não. Podem, como tais, ouvir-se gritar.

Jacques Lacan

Deixa o teu corpo entender-se com outro corpo.

Porque os corpos se entendem, mas as almas não.

Manuel Bandeira 


\section{RESUMO}

Cossi, R.K. (2016). A diferença dos sexos: Lacan e o feminismo. Tese (Doutorado), Instituto de Psicologia, Universidade de São Paulo.

Este trabalho investiga o debate estabelecido entre a psicanálise lacaniana e os estudos feministas e de gênero a respeito da diferença dos sexos, assim como os desdobramentos que a teoria da sexuação de Lacan pode trazer para esse tema. Examinamos a obra de autoras do feminismo francês indispensáveis para a pesquisa desta interface, no caso os de Irigaray, Cixous, Montrelay, Kristeva e Wittig - tais trabalhos, notadamente edificantes do movimento da escrita feminina, verificamos terem repercutido decisivamente tanto em Lacan quanto nos estudos de gênero contemporâneos. Investigamos a obra de Robert Stoller, a introdução do termo gender nesse contexto e o desenvolvimento de sua teoria do "núcleo de identidade de gênero", a ser debatida por Lacan no seminário XVIII e que constatamos ter sido determinante para o estabelecimento de sua noção de semblante. Detectamos que o lacanismo incorporado em solo norte- americano foi aquele que se voltou para o estruturalismo de Lévi-Strauss e as relações de parentesco, evidente nas obras de Rubin e Butler. Comprovamos que as críticas a Lacan giraram principalmente em torno das noções correlatas ao registro simbólico e seu suposto caráter apolítico e ahistórico, o que obrigou defensores da psicanálise a se pronunciar. Sob a hipótese de que a sexuação lacaniana poderia trazer novos ares para esta discussão, concluímos que tratar do falo enquanto função, da teoria dos gozos e de derivações dos aforismos "Não há relação sexual" e "A mulher não existe", a partir de recursos da lógica, da teoria dos números e dos conjuntos, acabaram por revigorar o entendimento lacaniano da diferença dos sexos, que se esquiva das prescrições heteronormativas e da binaridade dos gêneros.

Palavras-chave: Diferença dos sexos; Psicanálise; Feminismo; Gênero; Sexuação. 


\begin{abstract}
Cossi, R.K. (2016). The difference between the sexes: Lacan and feminism. Tese (Doutorado), Instituto de Psicologia, Universidade de São Paulo.
\end{abstract}

This thesis looks into the debate established between lacanian psychoanalysis and feminist and gender studies on the difference between the sexes, as well as the developments that Lacan's theory of sexuation can bring to this theme. We examine the fundamental french feminists's works that deal with this interface, in the case Irigaray's, Cixous's, Montrelay's, Kristeva's and Wittig's. Those works, especially edifying of the feminine writing movement, have had a decisive impact on both Lacan and in contemporary gender studies. We examined the work of Robert Stoller, the introduction of the term gender in this context, and the development of his "core gender identity" theory, to be criticized by Lacan in the seminar XVIII, and which we have found to be determinant in establishing the lacanian notion of semblant. We verified that the lacanian strand incorporated in United States of America was the one that turned to Levi-Strauss's structuralism and kinship relations, as we see in the works of Rubin and Butler. We realized that the criticisms to Lacan were about his notions established through the symbolic register and its supposed apolitical and ahistorical character, which compelled proponents of psychoanalysis to react. Under the hypothesis that the lacanian sexuation could move this discussion forward, we concluded that dealing with the phallus as a function, the theory of jouissance and derivations of the aphorisms "There is no sexual relation" and "The woman does not exist", from logic field, number theory and set theory resources, finally invigorated the lacanian understanding of difference between the sexes, which escapes heteronormative prescriptions and gender binarity.

Keywords: Difference between the sexes; Psychoanalysis; Feminism; Gender; Sexuation . 


\section{SUMÁRIO}

INTRODUÇÃO_ 10

1 LACAN E O FEMINISMO FRANCÊS__ 29

1.1 Irigaray e a batalha pela diferença___ 30

1.1.1 Contra Freud__ 34

1.1.2 Desobedecendo Lacan___ 40

1.1.3 Gozo e A mulher___ 43

1.1.4 Topologia___ 50

1.1.5 Kiss my lips__ 53

1.2 Cixous e a escrita transformadora___ 57

1.3 Montrelay e o gozo da sombra___ 66

1.4 Kristeva e o semiótico indomável__ 76

1.5 Wittig e o fim de homem e mulher___ 83

2 GÊNERO E LACAN__ 94

2.1 Stoller e o semblante lacaniano___ 94

2.1.1 Núcleo de identidade de gênero___ 99

2.2 A noção de semblante__ 108

2.2.1 Semblante, diferença sexual e performance___ 110

2.3 Rubin e o sistema sexo/gênero___ 116

2.4 Butler e a problemática lacaniana___ 123

2.4.1 Simbólico, lei e relações de parentesco___ 125

2.4.2 Gênero e norma simbólica__ 130

2.4.3 A questão fálica e a saída lésbica___ 134

2.4.4 A melancolia e a heterossexualidade compulsória__ 138

2.4.5 Revendo o simbólico _ 141

2.5 Preciado para além do sistema sexo/gênero___ 148

2.5.1 Revendo o falo___ 154

3 SEXUAÇÃO__ 158

3.1 Para o sexo psicanalítico__ 164

3.2 Diferença sexual, dois e um_ 175

3.3 Não há relação sexual: antecedentes___ 188

3.4 Não há relação sexual: gozo e lógica____ 194

3.5 A relação sexual falha de duas maneiras___ 205

3.6 A mulher não existe: tensões___ 206

3.7 As fórmulas da sexuação___ 215

3.8 Políticas da sexuação__ 224

3.8.1 Para além da anatomia, da prática sexual e do binarismo___ 225

3.9 Há-do-Um__ 243

3.9.1 Para uma compacidade sexual___ 250

3.9.2 Homem e mulher entre zero e um__ 253

4 CONCLUSÕES__ 260

REFERÊNCIAS_— 269 


\section{INTRODUÇÃO}

Psicanálise e feminismo nasceram praticamente ao mesmo tempo e apresentam um percurso interimplicado: "emaranhados, não apenas constituíram um ao outro, como também nunca viveram separados" (DIMEN in ROTH, 2000, p. 189). Relação conflituosa, união paradoxal, "como gêmeos que estivessem, desde o começo, destinados ao amor e a rivalidade infinitos" (BOWLBY in BRENNAN, 1997, p. 66).

Há tanto o engajamento da psicanálise no feminismo quanto a apropriação da psicanálise pelo feminismo. As intersecções são múltiplas: a teoria literária, a teoria do cinema, estudos sobre a pornografia, epistemologia. Um dos eixos comuns entre psicanálise lacaniana e feminismo diz respeito à investigação e aos desenvolvimentos teóricos quanto à diferença dos sexos e é por ele que envereda esta pesquisa. $\mathrm{O}$ interesse por esse tema decorre da nossa primeira aproximação do universo dos gêneros, quando, no mestrado, tratamos da transexualidade e do modo como a psicanálise lacaniana se voltou para ela. A descoberta da obra de Judith Butler, fruto de um feliz acaso, foi um divisor de águas. Daí nossa proposta inicial, nesta pesquisa de doutorado, de tratar da apropriação butleriana dos conceitos psicanalíticos que lhe serviram de instrumento para o desenvolvimento de sua teoria dos gêneros — interessava-nos sua leitura; investigar o uso que ela fez dos aportes lacanianos. Posteriormente, decidimos expandir nosso campo para abarcarmos as teorias feministas mais influentes que se voltaram para Lacan: descobrimos os trabalhos de Luce Irigaray, Hélène Cixous, Michèle Montrelay Julia Kristeva e Monique Wittig. Ao lado desse terreno francófono, constatamos que o lacanismo foi abarcado por outro viés em solo norte-americano, também nos anos 70: se na França prevaleceu um Lacan dedicado às pesquisas sobre os recursos da linguagem, Gayle Rubin introduz uma psicanálise lacaniana munida do estruturalismo de LéviStrauss atrelado às relações de parentesco, o que não é sem consequências. Nosso ponto de análise girou em torno dos elementos 'sexo', 'gênero' e 'gozo' — daí recorrermos à teoria da sexuação lacaniana, também desenvolvida nos anos 70, quando o Mouvement de Libération des Femmes (M.L.F.) estava no auge e Lacan acompanhava tudo de muito perto. Qual relação, quais diálogos, avanços, recusas teóricas podem ser estabelecidos entre feminismo e sexuação? Contribuição mútua ou divergências inconciliáveis? Não há consenso.

Para alguns, como Braidotti (in BRENNAN, 1997) e André (2016), métodos e propostas incompatíveis. Para outros, como Mitchell (1985) e Campbell (2004), o 
feminismo traz uma visão política da construção sócio-histórica das identidades sexuais que em muito interessaria ao lacanismo, seja no âmbito de suas construções teóricas ${ }^{1}$, seja no de sua clínica - no que tange a relação psicanalista-paciente — ou no próprio funcionamento político de suas instituições, ou mesmo na forma com que os analistas em formação acriticamente se referenciam aos textos canônicos e aos transmissores da doutrina, como já denunciava Monique Wittig (1992). O feminismo politizaria a psicanálise. Além do mais, o feminismo ilumina pontos cegos da teoria psicanalítica que os próprios psicanalistas não conseguem "explicar adequadamente", tais como as noções de 'falo' e de registro simbólico. Por outro lado, em que medida a psicanálise seria interessante ao feminismo? Prestaria algum auxílio no seu projeto de transformação social? Braidotti (in BRENNAN, 1997) acredita que não. E quanto ao seus aportes teóricos, contribuiriam em que e em que âmbito? Se se argumenta que a psicanalise é falogocêntrica e dá força ao patriarcado, há os que defendem que se trata de um sistema de pensamento que daria subsídios potentes para a implosão de identidades fixas, como quer Saez (2004).

O feminismo pode ser didaticamente dividido, segundo Lago (2010), em três ondas: a primeira é situada na virada dos séculos XIX e XX e no entre guerras, e pode ser denominada "feminismo da igualdade" - reivindicava-se direito ao voto, trabalho e cidadania, ou seja, igualdade social e política com relação aos homens. A segunda onda do feminismo, que foi até por volta dos anos 80, é chamada de "feminismo das diferenças". Agora, além do fortalecimento das demandas anteriores, a mulher se foca em si mesma, nas suas especificidades. A terceira onda do feminismo, a partir dos anos 90, muda de foco. A ênfase passa a ser a demanda por legitimação de novos modelos de identidade e práticas sexuais.

O grande interesse da psicanálise pela sexualidade feminina nos anos 20 guarda relação com os movimentos feministas desse período que visavam se contrapor às normas ditadas pela burguesia vitoriana - nesse âmbito, pregava-se que a discriminação e a inferiorização da mulher no espaço público e a falta de participação nos processos de produção seria decorrente da função reprodutiva que lhe cabia, ou seja, seu aparato biológico justificaria sua menor importância sócio-política.

Se se argumentava que Freud era interessante por desenvolver uma teoria que sustentava que o processo de constituição do sujeito como homem ou mulher é

\footnotetext{
1 “A construção social do desejo também é política, aspecto que a psicanálise nega resolutamente como uma ameaça a seu próprio poder institucional” (DIMEN in ROTH, 2000, p. 193).
} 
histórico ou cultural, na forma da trama edípica; por outro lado, também se denunciava seu caráter falocêntrico e mantenedor da subordinação da mulher a partir da pressuposição de que a diferença anatômica prescrevia a ela menor valor e inferioridade de condições quando comparada ao homem.

Surgem então, dentro do universo psicanalítico desse período, autores que se contrapunham a certas teses freudianas, tais como Ernest Jones, Melanie Klein, Hélène Deutsch, Karen Horney e Jeanne Lampl-de Groot, cujas ideias contribuíram para a articulação das posições feministas. Os principais pontos de divergência diziam respeito ao fato de o complexo de castração ser considerado um processo único, válido tanto para meninos e meninas; ao fato de a libido também ser única, masculina correlato de o falo ser encarado como instrumento teórico intrinsecamente atrelado ao pênis. Nesse sentido, o clitóris seria uma versão feminina do pênis, libidinalmente desinvestida à medida que a vagina entra em cena; contudo, a menina sempre padeceria da "inveja do pênis" — tese essa vigorosamente combatida por Horney.

Se a premissa é fálica, aqueles autores vão buscar então tentar explicar a mulher em si mesma, não através do modelo da organização da sexualidade masculina. Não à toa, enfatizam o período pré-edípico e a relação primordial mãe-fillho; deslocando, assim, o pai do lugar privilegiado prescrito pela teoria do Édipo. Grosso modo, pretendia-se fazer com que a feminilidade deixasse de ocupar um lugar secundário, de ser vista predominantemente como uma saída precária decorrente de suas mancas instâncias psíquicas quando comparadas às do homem. Freud estava atento e seu texto de 1931 é emblemático nesse sentido — ali ele reconhece a importância dessa fase pré-edípica, assim como sua dificuldade em teorizar sobre ela; e comenta os trabalhos de tais autores, sem abrir mão de suas prerrogativas: não existe uma fase fálica exclusiva das meninas, como queria Jones, e o falo tem papel central em ambos os sexos. É como se tais teóricos contrapusessem aquela período pré-edípico ao complexo de Édipo, "como se fossem excludentes, enquanto Freud os considerava como estratos psíquicos superpostos" (TUBERT in FLAX, 1990/1995, p. 14). Décadas depois, Kristeva também vai recorrer à fase pré-edípica, atrelando-a ao período semiótico no qual uma vulcânica dispersão pulsional imperaria, sob a proposta de ser motor de uma escrita transgressora.

Em 1949, Simone de Beauvoir publica $O$ segundo sexo, talvez a obra mais influente da teoria feminista do século XX. Dentre diversas denúncias, Beauvoir mostra como nascer "mulher" implica uma série de prescrições e defende que mulher é um 
produto da civilização, e não um dado natural. Destaca-se nesse trabalho a famosa sentença "não se nasce mulher, torna-se", que tem valor de origem mítica das definições construcionistas de gênero.

“Que é uma mulher?”, questiona Beauvoir (1949/1970); e responde:

A relação dos dois sexos não é a das duas eletricidades, de dois polos. O homem representa a um tempo o positivo e o neutro, a ponto de dizermos "os homens" para designar os seres humanos, tendo-se assimilado ao sentido singular do vocábulo vir o sentido geral da palavra homo. A mulher aparece como o negativo, de modo que toda determinação lhe é imputada como limitação, sem reciprocidade. [...] Praticamente, assim como para os Antigos havia uma vertical absoluta em relação à qual se definia a oblíqua, há um tipo humano absoluto que é o masculino. A mulher tem ovários, um útero; eis as condições singulares que a encerram na sua subjetividade; diz-se de bom grado que ela pensa com suas glândulas. $\mathrm{O}$ homem esquece soberbamente que sua anatomia também comporta hormônios e testículos. Encara o corpo como uma relação direta e normal com o mundo que acredita apreender na sua objetividade, ao passo que considera o corpo da mulher sobrecarregado por tudo o que o especifica: um obstáculo, uma prisão. [...] E é por isso que Benda afirma em Rapport d'Uriel: "O corpo do homem tem um sentido em si, abstração feita do da mulher, ao passo que este parece destituído de significação se não se evoca o macho... O homem é pensável sem a mulher. Ela não, sem o homem". [...] A mulher determina-se e diferencia-se em relação ao homem e não este em relação a ela; a fêmea é o inessencial perante o essencial. O homem é o Sujeito, o Absoluto; ela é o Outro. (BEAUVOIR, 1949/1970, pp. 9-10)

Beauvoir denuncia que naquele momento cultural a pessoa universal e o gênero masculino se fundem em um só termo, Homem. A mulher seria definida a partir dele - anatomicamente, inclusive, tal como Laqueur (2001) mostra a partir do modelo isomórfico dos corpos prevalecente até o século XVIII no Ocidente. Ao homem associar-se-iam elementos como mente e cultura, e à mulher, corpo e sexo - menos nobres, portanto. O homem é sujeito, a mulher é o Outro, expulsa do campo da subjetividade. Nessa ótica de Beauvoir, Freud seria herdeiro dessa tradição de pensamento que elege cegamente o masculino como origem e referência, cabendo à mulher ser sua vertente inacabada. Ou seja, Freud se sustentaria no patriarcado e daria “embasamento científico" à hegemonia masculina.

Se esse trabalho de Beauvoir exerceu influência decisiva para os gender studies, a incorporação inicial do termo gender na discussão em torno das identidades sexuais se deu em outro contexto. "Antes de se tornar um conceito maior dos estudos feministas americanos, a noção de 'gênero' é forjada e imposta dentro do contexto 
médico. Dois nomes são intimamente associados à sua gênese, John Money e Robert Stoller" (LEVET, 2014, p. 46).

John Money, psicólogo e sexólogo norte-americano, no seu trabalho com pacientes intersexuados, iniciado nos anos 50, passou a considerar que elementos biológicos poderiam não ser determinantes para a construção dos papéis sexuais associados ao gênero - em 1957 publica o clássico estudo clínico de gêmeos intersexuados a partir do que se teria constatado que o "sexo social", fruto da educação e do ambiente, triunfava sobre o "sexo hormonal ou cromossômico", ou seja, o comportamento sexual e a sensação de ser homem ou mulher não eram dados inatos. Então, se sexo biológico é distinto de "sexo social", um termo específico precisava ser forjado, gender, para se opor radicalmente ao biologizado sex, fatores esses não necessariamente atrelados. Robert Stoller - psiquiatra e psicanalista, parte desse grupo — cria, em 1964, a expressão "núcleo de identidade de gênero", cuja constituição será alvo de pesquisa por décadas em diferentes terrenos, de quadros clínicos como a transexualidade e a perversão a estudos etnográficos e pornografia.

Nos anos 70, o feminismo, inicialmente o anglo-saxão, se apropria do termo 'gênero'. A socióloga britânica Ann Oakley, segundo Levet (2014, p. 54), foi a primeira a adotá-lo, em 1972, em Sex, gender and society. Tratava-se de um termo muito útil tanto científica quanto politicamente, servindo como uma arma contra a ideia da naturalização da diferença dos sexos - gênero seria um elemento construído socialmente, ou seja, o que se entende por homem ou mulher varia segundo a época e a cultura.

Grosso modo, até aquele momento histórico a distribuição dos papéis sociais se dava de acordo com o sexo do indivíduo: se a natureza, imutável, determina o que são homens e mulheres, também seria a natureza o que justificaria as diferentes atribuições sociais - nesse sentido, mudando a chave: "se a natureza não dita a identidade de homens e mulheres, então a própria autoridade dos princípios sobre o qual repousa as sociedades erode" (LEVET, 2014, p. 54). Se 'homens' e 'mulheres' podem ser encarados enquanto construções sociais, os papéis sociais podem ser cambiáveis. Nessa passagem, a adoção do termo 'gênero' é fundamental: a identidade é generificada, ou seja, 'gênero' traz em si a ideia de que o que rege as identidades sexuais é um princípio de poder (LEVET, 2014, p. 55).

Segundo Levet (2014, p. 58), a teoria que se funda a partir do gênero permite a distinção de três níveis da identidade sexual: o sexo de nascimento ou o sexo 
biológico; o gênero, que o Estado e o meio social imputam ao indivíduo (assignação); e a sexualidade ou a orientação sexual — nesse caso, o termo 'gênero' revelaria que não há nada prévio a determinar a relação desejante entre homens e mulheres - a heterossexualidade natural passa a ser vista como um mito.

Nesse sentido, a escolha dos termos 'gênero' ou 'diferença sexual' é ponto crucial. A decisão por um ou outro, dentro do universo feminista ou dos estudos de gênero, implica posições teóricas e políticas completamente antagônicas. Sexual difference faz alusão direta à biologia - recusar essa expressão em prol de gender tem por intenção desconstruir a ideia de que a identidade sexual é determinada biologicamente. "Gender" passou a ser incorporado pelos estudos feministas da segunda onda, nos anos 60 e 70. E é somente nos anos 80 que o gender studies se impõe no universo norte-americano, onde até então prevaleciam feminist studies e women's studies, segundo Bereni \& Trachman (2014, p. 20). Contudo, "sexual difference" não tem a mesma conotação que "différence sexuelle", "différence des sexes" ou "diferença sexual" ou "diferença dos sexos" - tanto em francês quanto em português, tais expressões são imprecisas e não circunscrevem campos específicos da experiência sexual. Se uma fração do feminismo francês acata o termo 'gênero', a maior parte se mantém fiel a “diferença sexual”, o que não é ao acaso. Se sex aponta para o biológico e gender para o que é socialmente construído, manter o termo "différence sexuelle" tem a intenção de se destacar das visões estadunidenses com fins de manter a especificidade intrínseca a ele. Reação:

Uma das críticas mais importantes da teoria queer à psicanálise é precisamente que esta assume entre seus pressupostos a existência da diferença sexual. A partir disso, a psicanálise é acusada de ser um instrumento de consolidação do binarismo homem/mulher, e de promover categorias de gênero binárias e heterocentradas. (SAEZ, 2004 , p. 191; trad. nossa)

Por outro lado, o termo 'diferença sexual', tal como entendido por Copjec, Zizek e Zupancic, apontaria para o que justamente excederia o gênero, revelando o que ele não pode comportar.

A filósofa feminista Geneviève Fraisse afirma que se "sexual difference" conota a realidade material do humano, seu aparato físico, já "différence sexuelle" pressupõe uma diferença entre os sexos, elemento ontológico que permite pensar numa definição dessa diferença, seja biológica ou filosoficamente. "Différence des sexes", por 
outro lado, implica o reconhecimento empírico dos sexos sem induzir nenhuma definição de conteúdo, "essa dualidade não implica nem afirmação de sentido, nem proposição de valor" (FRAISSE, 2010, p. 418). O termo 'diferença dos sexos', segundo Fraisse (2010, p. 463), permitiria nos furtarmos da escolha entre dois polos extremos e uma inevitável definição da dualidade sexual. Sairíamos do campo da ontologia — que tanto gender ou différence sexuelle prescrevem - para o campo da política. De toda forma, uma separação tendeu a ser configurada dentro do movimento feminista da segunda onda - por um lado, gender studies norte-americanos, por outro, as teóricas da diferença dos sexos europeias. A porta de entrada no edifício lacaniano também foi diferente.

Se a primeira onda do feminismo exigia igualdade dos sexos e uma melhor participação da mulher na vida social, o feminismo dos anos 70, segundo Fraisse (2010, p. 284), traz a novidade de analisar o lugar ocupado pelas mulheres no sistema de produção do trabalho e na relação familiar, propondo que essa condição seja analisada em termos de opressão e exploração - a dimensão política entra em cena. Foca-se o mecanismo em jogo no sistema patriarcal que subjuga as mulheres. Denunciar a opressão anda ao lado da proposta de uma estratégia de libertação. O Mouvement de Libération des Femnes surge em 1968, contemporâneo ao movimento da escrita feminina. Os trabalhos de Irigaray, Cixous, Montrelay, Kristeva e Wittig ganham destaque, fortemente marcados pela teoria de desconstrução de Derrida. Feministas que flertavam com a psicanálise, chegando algumas a frequentar os seminários de Lacan ou mesmo a se dedicar à formação como psicanalistas. Foi Montrelay, inclusive, quem apresentou a obra de Duras a Lacan. Nesses anos de efervescência, o psicanalista francês profere o Seminário XX, que, em bons momentos, toma o feminismo da época como interlocutor.

Devemos observar que, se a psicanálise influenciou as teorias feministas, também se viu afetada, mais uma vez, pelos avanços dos movimentos das mulheres: nos anos 70 se estabeleceu, paralelamente ao florescimento da teorização feminista, um debate análogo ao dos anos 20-30, mas não mais centrado na obra de Freud, mas a partir das propostas de Lacan. (TUBERT in FLAX, 1990/1995, p. 20; trad. nossa)

O curioso é que é nesse momento Lacan lança seu aforismo-bomba: 
Nos anos 70, ao formalizar a tese da inexistência da relação sexual, para desgosto da plateia feminista francesa que na época buscava as bases teóricas para sustentar não mais a igualdade, como em um primeiro momento do feminismo, mas a especificidade da mulher em relação ao homem, Lacan afirma que 'A mulher não existe'. (FUENTES, 2009, p. 22)

Esse feminismo francês se mune principalmente do lacanismo que se dedicou ao estudo da linguagem para a implantação de uma escrita revolucionária a inscrever o que seria o mais próprio do feminino no tocante a seu corpo, com a pretensão de abalar o sistema patriarcal e o simbólico que não permitiria outras representações da mulher: "seus expoentes afirmam [...] que na então chamada ordem falocrática da linguagem, batizada de "simbólico masculino", não há lugar para a prática feminina de escrita" (WRIGHT, 2000, p. 7).

Já do outro lado do Atlântico, a antropóloga Gayle Rubin, em 1975, inventa o sistema sexo/gênero e funda uma vertente de trabalho sobre gênero no campo das ciências sociais. Lacan também é discutido, mas nas depurações simbólicas fruto de sua apreensão do trabalho de Lévi-Strauss a respeito das estruturas elementares de parentesco: o simbólico lacaniano subsidiaria as relações sociais que condenam as mulheres a objetos de troca. A castração é encarada como dimensão subjetiva da proibição estruturante da ordem social, o tabu do incesto. A lei simbólica lacaniana seria então uma lei marcada pela regência das relações de parentesco heterossexuais a subjugar as mulheres e os "desviantes". Temos um Lacan atrelado à ideologia e às desventuras do poder.

Nos Estados Unidos dos anos 80, ao contrário do que ocorreu na França, segundo Fassin (in BERENI; TRACHMAN, 2014, p. 85), 'gênero', além de elemento teórico, passa a ser uma categoria institucionalizada: revistas acadêmicas são lançadas sob tal inspiração; congressos, organizados; programas específicos nas formações universitárias são criados - chegando a departamentos serem inaugurados dentro da Academia dedicados exclusivamente a gênero. Todo um campo de estudo autônomo surge e conceitos lacanianos são incorporados aos cultural studies. Nesse sentido, cabe destacar que em solo norte-americano foi, em grande parte, pelo mundo das artes voltadas à causa feminina - mais especificamente da literatura e do cinema - que a psicanálise teve seus instrumentos utilizados: trabalhos importantes como o de Copjec, Imagine there's no woman (2002) - que trata da representação do feminino e dos papéis da mulher em filmes e nas artes visuais — surgem em larga escala. Nesse caso, 
importa a função da imagem (reprodução de imagens fetichizadas da mulher), do olhar (olhar masculino sobre ela) e da relação produtor-espectador — por exemplo, o olhar do espectador é construído dentro do campo de visão masculino nos filmes clássicos de Hollywood, segundo Wright (in BRENNAN, 1997, p. 198). As feministas começam a analisar os filmes como estrutura de fantasia e as posições masculina e feminina que ela comporta. "Fantasia" seria pedra angular, o que a historiadora Joan Scott já havia detectado.

Se, num primeiro momento, os estudos feministas problematizavam o lugar da mulher na sociedade, os estudos de gênero não se limitam às mulheres. Não se trata mais só de advogar pela desnaturalização da diferença dos sexos, mas de tornar visíveis outras formas de lidar com o gênero, para além do masculino e do feminino, e questionar a própria metodologia intrínseca ao feminismo - o que fica mais evidenciado nos anos 90. O trabalho de Judith Butler — ao dialogar com Irigaray, Wittig e Kristeva - é referência dessa empreitada. Nos anos 90, a própria noção de ‘sexo anatômico' enquanto elemento binário fixo determinado pela natureza passa a ser alvo de releituras críticas. Também se constata que toda a ênfase na estratégia de coletivizar a mulher como forma de se contrapor ao homem acabou gerando uma crítica interna ao movimento feminista, ao denunciar que não se estava levando em conta as diferenças existentes entre as próprias mulheres, assim como elementos como raça, cor e classe social. Consequentemente, o pós-modernismo passa a fazer parte do debate, pondo em questão a própria noção de 'identidade' e de 'fixidez do sujeito' (WRIGHT, 2000, p. 6). Inaugura-se a dimensão da interseccionalidade, focando as lutas internas ao feminismo - dos subaltern studies se chega aos trabalhos pós-estruturalistas e à teoria queer.

Nos termos de Bereni \& Trachman (2014), inicialmente o movimento feminista sustentava a postura construtivista com a intenção de romper com o essencialismo biologizante; num segundo momento, focava-se a dimensão relacional e se pretendia tratar os dois gêneros em conjunto, o que permitiu revelar a relação hierárquica estabelecida entre eles; posteriormente, as relações de poder são examinadas para além do patriarcado e da dominação masculina, focando a normatização do gênero que sanciona o legítimo e o ilegítimo. Nesse caso, os estudos de gênero também se prestam a investigar a dinâmica de diferenciação que atua dentro do grupo dos homens a partir do que se postula como "homem de verdade" — não à toa, o homem e a 
masculinidade passaram a ser alvo de pesquisa na contemporaneidade, haja vista os trabalhos de Stephen Frosh (1994); e, mais recentemente, de Pedro Ambra (2015).

Quanto ao lacanismo, seja na forma com que entrou nos Estados-Unidos por sinal, o feminismo foi a grande porta de entrada da psicanálise lacaniana em solo norte-ameircano - , seja no universo francófono, uma arma de guerra é dirigida contra o simbólico de Lacan e suas noções correlatas, como 'falo' e 'Nome-do-pai', em perspectivas diferentes. Mesmo no projeto de recorrer aos instrumentos da linguagem para tratar dos referenciais canônicos da psicanálise, Lacan teria se mantido patriarcalista, agora prescrevendo relações de submissão da mulher através da ordem simbólica: "o problema eminente é que o simbólico de Lacan faz com que o patriarcado pareça inevitável” (BRENNAN, 1997, p. 12). A dominância fálica ainda imperaria, irremediavelmente, para muitas feministas, atrelada ao pênis. Apesar de não ignorar a dimensão simbólica do falo, que se trata de um significante marcado pela falta, e que a diferença é concebida tendo como condição a linguagem, o reconhecimento visual da diferença sexual se atrelaria, para Brennan, a uma experiência corpórea: "É neste ponto que o argumento se desvirtua. Pelo fato de parecer mais visível, e porque pode representar a falta, o pênis ocupa o lugar do falo potencialmente neutro" (BRENNAN, 1997, p. 13). Por mais que o falo seja um significante que nada representa, quando o corpo entra em jogo, para ela, a representação visual da diferença sexual faz com que o falo seja "representado de um modo masculino unilateral. [...] o vínculo entre o falo e o pênis existe, e persiste" (BRENNAN, 1997, p. 14). Ou seja, "a questão a respeito da posição ideológica de Lacan - falocrata ou feminista - depende em grande parte do significado que se atribui ao falo" (GALLOP, 1985, p. 133).

Outro ponto de crítica que se endereça recorrentemente à psicanálise diz respeito à negatividade que Lacan agregou aos conceitos. Negatividade essa, expandida ao simbólico, que leva à consideração de que os seus aportes teóricos esvaziados não teriam em nada a contribuir para a operacionalização de transformações sociais concretas. Flax afirma que Lacan "elimina questões promissoras sobre o caráter "inevitável" de mal-estar na cultura que Freud sugere" — os traços históricos e mutáveis que compõem as relações de dominação não são detectáveis em Lacan, já que "são colocados como efeitos de uma lógica universal da linguagem" (FLAX, 1990/1995, p. 174 ). Mais adiante, “o sujeito se converte em uma chave linguística para obscurecer em parte sua própria pré-história" (FLAX, 1990/1995, p. 196). Assim, a psicanálise se manteria fortemente edificada sobre premissas do patriarcalismo, ao 
passo que não forneceria meios de revertê-lo. Em outros termos, o simbólico prescreveria relações de poder na forma de um binarismo inflexível — tal interpretação feminista vingou, tanto na França de Cixous quanto nos Estados Unidos de Butler e Flax.

\begin{abstract}
Ao invés de encorajar o desenvolvimento de um "self" mais fluido, Freud acaba tentando unificar as forças da mente sob o controle do Um (ego) em aliança com o Real (o princípio da realidade). Ele desloca conflitos existentes dentro da cultura aos existentes entre "natureza" e cultura; consequentemente, torna suas origens sociais opacas e inacessíveis, especialmente nas relações de gênero e no discurso da dependência. Ele deixa como legado à psicanálise um jogo de dualismos que segue governando seu discurso hoje em dia: corpos como natureza oposta à mente e à cultura, razão ou lei opostas a um eu relacionado a objetos, masculino oposto ao feminino, o correto ou a justiça opostos ao desejo, o indivíduo dependente da comunidade, porém oposto a ela. Dentro desses dualismos podem se acomodar [...] a conformidade social de Hartmann e a psicologia do ego, [e] o autoritarismo hermético de Lacan [...]. (FLAX, 1990/1995, p. 381; trad. nossa)
\end{abstract}

Podemos dizer que, em larga medida, a psicanálise entrou em solo norte americano como uma terapêutica adaptativa, o que em muito contribuiu para seu demérito. Creditava-se a ela a meta de que os impulsos inconscientes deveriam ser reprimidos ou controlados - o que ecoou longe, haja vista o entendimento de lei como normativa em psicanálise por grande parte do feminismo, e do sujeito como dócil. Por outro lado, surgem autores que afirmavam que fatores como o inconsciente e a pulsão não foram vistos em seu original caráter indomável. Assim como sustentavam que o mal-estar das mulheres não era somente devido a desvantagens que o meio externo lhes imputava.

Se há, então, as feministas antipsicanálise, por enxergarem em Lacan e em Freud elementos que reimporiam a lei patriarcal que truncava a emancipação das mulheres -, recorrer à psicanalise levaria a recaírem no erro ou tomarem como aliado o inimigo do qual queriam se livrar - , existem as feministas pró-psicanálise, segundo Bowby (in BRENNAN, 1997, p. 64), ao enxergarem nela elementos de intransigência que viriam ao auxílio das mulheres na luta política contra a opressão.

Não por acaso, surgem trabalhos que visam restituir o essencial da psicanálise, os fundamentos basais que teriam sido mal interpretados pelas feministas: 
Freud e Lacan foram muito deturpados, não somente no âmbito da clínica psicanalítica e da Academia, mas também no da imprensa comum. Clinicamente, ambos foram recusados por muitas feministas por terem sido encarados como prejudiciais à causa da mulher, já que suas teorias a respeito da feminilidade foram consideradas sexistas e heterossexistas. Mesmo nos momentos em que é dado crédito a eles graças à teoria do inconsciente e da sexualidade, isso é feito de forma relutante. Freud continua a ser acusado por seu comprometimento com a inveja do pênis e com os complexos de Édipo e da castração; Lacan, pela sua releitura de Freud nos termos de centralidade do falo e da função simbólica da paternidade. Muitas feministas que, por outro lado, realizam trabalhos relevantes, irão repetir aquelas primeiras acusações contra ambos sem encarar a batalha com os indubitavelmente difíceis textos lacanianos; ou, se o fazem, elas farão sua escolha pelos Escritos, ao invés de darem uma olhada no que a mais há de publicado. (WRIGHT, 2000, pp. 13-4; trad. nossa)

Da Inglaterra vem o trabalho de Juliet Mitchell, Psychoanalysis and feminism, de 1974, empenhado em retratar o freudismo supostamente distorcido pelas feministas americanas da época, e que não teriam dado a devida importância a todo o impacto do inconsciente e da sexualidade tal como concebida por Freud. Mitchell argumentava que a psicanálise explicaria o que teria promovido a ascensão do patriarcado, mas não daria sustentação a ele. Outro trabalho de Mitchell, ao lado de Jacqueline Rose, Feminine sexuality: Jacques Lacan and the école freudienne, de 1985, desempenha a mesma função no universo anglo-saxão, agora se dedicando ao lacanismo. Mitchell e Rose focam o salto dado por Lacan ao incorporar a função da linguagem à teoria: salienta a especificidade do desejo ao se contrapor à demanda e à necessidade, a importância de se conceber homem e mulher enquanto significantes e de reconhecer o caráter subversivo e fragmentado do sujeito da psicanálise. Outros trabalhos de fôlego desse momento são os da norte-americana Jane Gallop: The daughter seduction (1982) e Reading Lacan (1985).

Nas décadas de 90, ainda nessa empreitada de redimir Lacan e melhor inserir seu pensamento nos Estados Unidos, surgem as obras de Ellie Ragland-Sullivan, Jan Campbell, Kirsten Campbell, Elizabeth Grosz. Um dicionário dedicado à interface entre feminismo e psicanálise é lançado, editado por Elizabeth Wright, também autora do livro de bolso Lacan and the post-feminism. Em 2002, é publicado Reading seminar $X X$, editado por Suzanne Barnard e Bruce Fink. Os trabalhos de Joan Copjec, Charles Shepherdson, Alenka Zupancic e Slavoj Zizek são referência nessa proposta de elucidar o lacanismo, que teria sido mal empregado pelos estudos de gênero - notadamente a respeito do entendimento da diferença sexual e do registro simbólico. Esse movimento 
também se vê na França de hoje, quando Leguil (2015), David-Ménard (2009) e Fajnwaks \& Leguil (2015) abordam a leitura dos estudos de gênero que recorrem a Lacan como uma tentativa de resgate do "básico" da psicanálise.

Outro ponto de grande debate próprio aos estudos de gênero contemporâneos diz respeito às consequências da adoção do sistema sexo/gênero como parte de seu método. $\mathrm{O}$ dualismo intrínseco a ele, no fundo, limitaria a análise feminista, segundo Raz (in BERENI, 2014, p. 63), já que engessado dentro do raciocínio natureza/cultura ou, nos termos de Preciado, essencialismo/construcionismo, o que deixaria de fora a vertente do corpo. Beatriz Preciado (2002) denuncia tal omissão presente na teoria de Butler, por exemplo, por não ter concebido que nem tudo do gênero é performatizável, e traz Teresa De Lauretis e Donna Haraway para a discussão no que tange à tecnologia de gênero e concebe um instrumento prostético que romperia com aquela binaridade. O corpo pulsional faz eco aqui, mais tarde reconhecido por Butler.

Preciado é fortemente influenciada por Monique Wittig, cujo feminismo radical pregava a extinção total dos termos 'sexo' e 'gênero', já que infalivelmente carregariam marcas do binarismo e hierarquia. O nome 'mulher' deveria ser apagado da escrita, como afirma Spivak (in BRENNAN, 1997, p. 294). Nessa perspectiva, Drucilla Cornell e Javier Saez enxergam a utilidade do aforismo lacaniano "A mulher não existe", ao pôr em xeque os aspetos imaginários que participam da construção da fantasia social que acorrenta identidades políticas do movimento feminista. Em certa medida, pode-se conceber que a sexuação lacaniana, no que dispõe de experiências de gozo, é modelo que também dispensa o gênero? Nos termos de Fink: "Não há, até onde vai meu conhecimento, uma fácil superposição entre sexuação, "gênero", ou entre sexuação e "identidade sexual", ou entre sexuação e o que às vezes é referido como “orientação sexual"” (FINK in BARNARD; FINK, 2002, p. 36). A leitura que se faz da sexuação também revela implicações políticas.

Se Freud tratava das consequências psíquicas referentes às diferenças anatômicas entre os sexos, Lacan vai tratar da posição sexual no âmbito do que veio a designar como ser falante (parlêtre), no trâmite entre os registros simbólico, imaginário e real, "o que permite romper com a ideia do complexo de Édipo como mito, em prol de uma logicização da diferença sexual” (BROUSSE, 1991, p. 114). E, mesmo nesse momento mais avançado, há quem sustente que "a crítica feminista do falo é baseada 
numa má interpretação do que o processo de sexuação implica" (WRIGHT, 2000, p. 23).

Por mais que o postulado lacaniano do ser e ter o falo dos anos 50-60 tenha sido encarado como a marca a distinguir homem e mulher, o que de certa forma pode levar à interpretação de que uma complementariedade entre os sexos estaria subsumida, a mulher se convertendo naquilo que falta ao homem, com a sexuação Lacan decreta a não relação sexual, a ser fomalizada logicamente nas suas diferentes formas de falhar. Ambos os sexos têm de lidar com a falha intrínseca à não relação sexual, cada um à sua maneira. O falo é agora dessubstancializado, a ser tratado como adjetivo, função dentro da lógica, função fálica e gozo fálico — ambos da alçada de homens e mulheres. Evidencia-se nas tábuas da sexuação do Seminário XX que lado 'homem' e lado 'mulher' são regidos por lógicas diferentes. Se o falo é indispensável a ambos, ele não é mais o único elemento em jogo: objeto $a$ e $S(A)$ se inscrevem na diferença dos sexos. Além do mais, o falocentrismo tem uma faceta limitadora ao impedir que o homem acesse a mulher.

Por outro lado, se predomina a interpretação de que a sexuação não trata dos seres falantes enquanto entidades biológicas, não prescreve práticas sexuais e não exige que o homem nem a mulher sejam obrigados a se posicionar do lado esquerdo ou direito das fórmulas, ainda existe a leitura de que Lacan mantém-se no binarismo e não apresenta de forma clara ao que está se referindo quando diz 'homem' e 'mulher'. Ora utiliza os termos 'homem' e 'mulher', ora 'macho' e 'fêmea', também fala em 'masculino' e 'feminino', sem que se saiba ao certo a que faceta do sexo ou da sexualidade ele está se referindo. Será que tal obscurantismo seria à toa? Temos a hipótese de que talvez Lacan não pretendesse abrir mão das várias chaves de leitura para se pensar homem e mulher enquanto sexualmente diferentes — são várias as suas referências entusiasmadas a respeito das descobertas genéticas, inclusive. Pensamos que seu esforço era mais dirigido a um ponto: com o que o discurso psicanalítico pode contribuir pra esse tema. No caso, seria a partir do aforismo "não há relação sexual". Se a relação sexual não se escreve, a não relação sexual, nós deveríamos nos esforçar para logicamente escrevê-las, nas suas duas formas de não se dar.

Lacan insiste na desproporcionalidade das duas experiências de gozo, gozo fálico e Outro gozo, mas que não chegam a “2”. Para a formalização da não relação sexual, Lacan também recorre à teoria dos números e à dos conjuntos — zero e Um; finito e infinito; e uma lógica para além da aristotélica, ao desvirtuar o princípio da não 
contradição. As tábuas da sexuação expõem dois lados, 'homem' e 'mulher', mas se pode argumentar que a relação entre eles não é como uma relação binária que prevê dois elementos ontologizados, um a submeter o outro.

Fraisse (2010, p. 86) aponta que a psicanálise foi um dos motores das novidades trazidas para o campo do sexual no século XX. Para a filósofa francesa, a psicanálise teve o mérito de tratar a diferença sexual e a sexualidade para além da bipartição homem/mulher e do sexo restrito à reprodução: "sexo" não é um elemento que só diz respeito ao feminino, tal como nos tempos antigos, mas um elemento que faz parte da vida psíquica de todos — "a vida sexual é doravante um evento cultural, no qual o instinto se chama pulsão".

Existe uma antiga forma de pensar homem e mulher; no caso, a partir da relação que se estabelece entre eles. 'Masculino' e 'feminino' são absolutos e relativos: absolutos como definições diferenciadas da humanidade; relativos porque ligados assimetricamente um ao outro, segundo Fraisse (2010, p. 88). A diferença dos sexos aponta para o "reconhecimento de um conflito inerente à relação entre os sexos, de um desacordo" (FRAISSE, 2010, p. 107), o que nos faz eco ao famoso aforismo lacaniano.

\begin{abstract}
Ao mesmo tempo, um século de textos e discursos psicanalíticos mostra quanto essa ruptura fundamental no pensamento não leva necessariamente a uma transformação dos sentidos dos discursos relativos à posição feminina na relação entre os dois sexos. Essa revolução epistemológica se conjuga facilmente com o resseguro político da tradição patriarcal, das relações mais triviais da relação sexual. O fato de que a psicanálise retoma — de Freud a Lacan, principalmente - a tradição antiga da diferença sexual merece uma reflexão [...]. (FRAISSE, 2010, p. 126; trad. nossa)
\end{abstract}

A diferença sexual não é um objeto da filosofia, de acordo com Fraisse. "Diferença sexual" anda ao lado de "questão da mulher"; mas como, ao longo da história Ocidental, a mulher é associada à carne ou à natureza, ao que resiste à reflexão, não fazia sentido a diferença entre homem e mulher ser concebida como entidade a merecer tratamento filosófico. "Diferença sexual" não é um filosofema e não entra como tal no discurso filosófico; contudo, há abertura para que se possa pensá-la a partir de elementos terceiros, como amor, pensamento ou corpo — foi só partir de Kierkegaard e outros filósofos modernos que tal cenário teria mudado (FRAISSE, 2010, p. 39). 
O corpo no Banquete não é um corpo sexuado. A androginia é o princípio primordial dos sexos. Sexo se aproxima do latim secare, cortar. Nesse sentido, o andrógino não tem sexo, ele foi cortado ao meio e os dois seres apartados se "sexuaram", diferentemente. A cisão promove as diferenças entre os sexos e está intrinsecamente atada a suas representações: "se o filosofema carrega uma falha, se o discurso sobre os sexos é sempre cindido, é porque os sexos escapam por si próprios à representação, exceto se se trata de descrever a eternidade do masculino e do feminino" (FRAISSE, 2010, p. 73).

Mas o objeto 'gênero' foi criado. Sua adoção fortalece a oposição natureza/cultura na roupagem de biologia/sociedade; porém, nega-se o sexuado em prol de uma análise social (FRAISSE, 2010, p. 49). Perde-se aquela antiga representação da relação masculino/feminino e do conflito inerente a ela; perde-se a chance de se colocar a diferença como questão, tensão, o jogo entre o idêntico, o mesmo e o diferente; além de sumir com o "sexo", cisão nunca totalmente representável.

"Se se inscreve doravante a psicanálise na história da filosofia, na cronologia dos "sistemas filosóficos", tem-se o direito de anunciar a emergência do filosofema "diferença dos sexos" (FRAISSE, 2010, p. 126). Mas se a psicanálise produz tal objeto, é justamente "para melhor mostrar sua impossibilidade teórica" (FRAISSE, 2010, p. 133). Assim, "só se prejulga uma definição possível da diferença dos sexos, é uma categoria vazia, um conceito vazio. [...] Precisemos: vazio não significa neutro" (FRAISSE, 2010, p. 369).

No primeiro capítulo pretendemos analisar a obra de grandes teóricas do feminismo francês, mais especificamente no que se voltaram para a teoria lacaniana quando a diferença sexual estava em pauta. Não fizemos um levantamento exaustivo de todas as obras de tais autoras, nem pretendemos dar conta de todas as feministas que trataram da psicanálise lacaniana. Recorremos às que constatamos ser as mais influentes e as mais comentadas, assim como a seus trabalhos mais proeminentes nessa intersecção psicanálise-feminismo no tema proposto.

Inicialmente nos voltamos para Luce Irigaray, talvez a feminista francesa que mais tratou do lacanismo. Verificamos que Irigaray pretendia criar condições para que outras representações da mulher pudessem ser edificadas, não aquelas ditadas pelo sistema patriarcal sustentado pelo Mesmo. Para que as especificidades da mulher pudessem ser contempladas, o simbólico deveria ser reconfigurado, as particularidades do corpo da mulher deveriam ser passíveis de entrar no discurso. Estratégias são 
pensadas: mimesis, reconfiguração da relação mãe-filha, simbolização dos dois lábios, a invenção de uma escrita feminina. Irigaray repensa a diferença sexual partindo dos termos de Freud até os de Lacan, voltado ao gozo e à topologia. Também é caloroso o debate a respeito do suposto essencialismo de suas ideias dentro do universo feminista. Hélène Cixous apresenta trabalhos emblemáticos nessa proposta de denúncia do falocentrimos psicanalítico. Constatamos que ela talvez tenha sido a principal voz do movimento da escrita feminina - a ser expandido para outras manifestações artísticas —, que pretendia acionar o gozo feminino e desmantelar as estruturas prescritas pelo simbólico e os padrões masculinos supostamente privilegiados por ele. Cixous atribui um caráter ideológico ao falo e à linguagem tal como concebidos pela psicanálise. Michèle Montrelay adota a postura política dessas duas teóricas do feminismo. Próxima de Lacan, traz a obra de Duras para o centro do debate - sua protagonista seria a expressão mais autêntica do gozo feminino, o que Montrelay veio a denominar sombra, flertando com a perplexidade do real. Atestamos que Montrelay concebia que tal propriedade feminina poderia ter implicações diretas na técnica psicanalítica incidências próprias na transferência, por exemplo. As dimensões do ritmo e da sonoridade deveriam ser levadas em conta tanto na escrita quanto na escuta do sujeito mulher, onde talvez o feminino implosivo mais se colocasse. Julia Kristeva perseguia um tipo de experiência literária completamente disruptiva. Acompanhamos todo o seu esforço em sustentá-lo teoricamente a partir das noções psicanalíticas de 'pulsão' e de 'período pré-edípico'. Texto e sujeito seriam coextensivos. Kristeva acrescenta as especificidades do que veio a denominar 'período semiótico', a se contrapor à suposta rigidez do simbólico lacaniano - o semiótico não formatável forneceria elementos que serviriam de motor de uma escrita revolucionária. Verificamos que, ao lado de todo o seu rigor de formalização linguístico, a proposta de Kristeva não foi tão bem recebida pelo universo feminista da época - as teses da autora pretendiam romper com identidades fixas, acionar um tempo em que a diferença sexual ainda não existisse, o que não privilegiaria a luta das mulheres. Monique Wittig é emblema do feminismo radical que quer erradicar 'homens' e 'mulheres' enquanto categorias discursivas, ao passo que também se verte àquela proposta de escrita transformadora. Constatamos que seu embate com Lacan se dá tanto no plano teórico quanto nas relações de poder que se imiscuiriam nas instituições psicanalíticas e no enquadre clínico psicanalítico. Conjecturamos que sua defesa pelo fim do sexo e o fim do gênero pode dialogar com a sexuação lacaniana que se presta ao gozo no tratamento da diferença dos sexos. 
No Capítulo 2 focamos importantes trabalhos que comtemplavam "gênero", talvez os de maior visibilidade, levando em conta nosso recorte. Assim como fizemos no Capítulo 1, não pretendemos estabelecer um levantamento de todas as obras ou autores que versaram sobre gênero e Lacan, mas o que pudemos verificar serem os indispensáveis. Tratamos inicialmente da obra de Robert Stoller e sua concepção de "núcleo de identidade de gênero". O autor focava sobretudo os fatores psicológicos e ambientais compondo a identidade sexual, daí recorrer a gender. Verificamos que o psicanalista norte-americano atribuía caráter ontológico a tal elemento, o que foi criticado tanto por Butler quanto por Lacan. No Seminário XVIIII discute-se a tese de Stoller, e observamos que é a partir desse momento que Lacan trata o semblante enquanto sexualizado - passa-se da teoria dos discursos para a da sexuação. Pudemos detectar que Stoller também efetua importantes releituras da teoria freudiana que versa sobre a constituição da identidade sexual, creditando força ao período pré-edípico, sob inspiração de Jones e Horney. Na sequência, abordamos o trabalho de Gayle Rubin, idealizadora do "sistema sexo/gênero". Rubin interpreta Lacan via estruturas elementares de parentesco, o que foi decisivo para a leitura mais forte do lacanismo a ser estabelecida em solo norte-americano. Segundo a antropóloga, essa vertente da psicanálise decretaria as relações de parentesco heterossexuais como ideais e as mulheres ainda seriam tidas como objetos de troca - agora a partir do simbólico lacaniano. Butler tem em Rubin uma de suas grandes inspirações. Constatamos que a filósofa põe em relevo dois pontos problemáticos em Lacan: a relação 'homem - ter o falo' / 'mulher - ser o falo' e o enunciado a respeito da "assunção do sexo" como efeito da castração simbólica. Sua interpretação quanto às prescrições da ordem e da lei simbólicas obrigou que autores como Shepherdson, Zizek, Ragland-Sullivan, Copjec, Zupancic, Saez, Campbell, dentre outros, entrassem no debate, agora reagindo a essas leituras críticas feitas pelos estudos de gênero. No último item desse capítulo, tratamos de algumas ideias de Preciado - do falo lésbico butleriano e do gênero enquanto performance vai-se em direção ao dildo como elemento tecnológico a romper a díade sexo/gênero e (re)introduzir a dimensão do corpo. Preciado discute tanto com a teoria queer quanto com o lacanismo fálico, o que nos incitou a indicar o falo como objeto a ser tratado nos três registros de Lacan; e, principalmente a partir dos anos 70, a ser encarado como função dentro da lógica. O que nos serviu de ponte para o terceiro capítulo da tese. 
Constatamos que no Seminário XVIII Lacan começa a se dedicar à formalização lógica de um novo modelo teórico: a sexuação. O registro do real ganha destaque e a noção de gozo, mais espaço; o falo, agora, qualifica um tipo de gozo e um tipo de lógica, a ser encarado como elemento que, se permite a ilusão da complementariedade dos sexos, também a impede. Passamos a tratar da especificidade da noção de 'sexo' em psicanálise, na ótica de Copjec, e da diferença sexual, com Le Gaufey, também recorrendo a Foucault e Laqueur. Se havíamos notado que Lacan já teorizava muito antes sobre a dissimetria entre homem e mulher, agora ela é enfaticamente explicitada com seu aforismo "não há a relação sexual" — que, por sinal, a nosso ver, é a grande contribuição que o discurso psicanalítico pode trazer para essa polêmica. A sexuação propõe pensar 'homem', 'mulher' a partir da teoria dos números, dos conjuntos, dos gozos, do estatuto do falo, agora tomado como função - o que faz rever a suposta edificação binária deste modelo teórico — , obrigando a repensar a implicação dos registros entre si e invocar o corpo enquanto terreno da experiência gozoza. Também apresenta toda uma valência política a ser explorada, haja vista o âmbito desidentificatório previsto pelo aforismo "A mulher não existe", a fluidez de suas posições e o caráter não dicotômico e não hierárquico que pode ser creditado à relação entre elas em suas fórmulas. 


\section{LACAN E O FEMINISMO FRANCÊS}

O feminismo francês dos anos 70 foi fortemente influenciado por pensadores como Freud, Foucault e Derrida, tendo cada um contribuído a seu modo para o questionamento da lógica da identidade, do essencialismo e da diferença. De Freud deriva o postulado do inconsciente como elemento a fragmentar o sujeito coerente da filosofia; de Foucault, a desestabilização da unidade a-histórica atribuída ao corpo - o entendimento do corpo também é efeito de práticas discursivas institucionalizadas e disciplinares, sendo ao mesmo tempo campo de resistência; de Derrida, provém a noção de falogocentrismo e a estratégia da desconstrução, inicialmente aplicada à análise filosófica e literária de textos.

'Logocentrismo' é o termo que Derrida usa para designar a forma dominante da metafísica do pensamento ocidental, sistema de pensamento esse baseado na lógica da presença para a busca da verdade e para o acesso aos conceitos e às coisas em estado puro e transparente. O logocentrismo se baseia fortemente na lógica da identidade, da exclusão e da polarização binária da diferença, tal como se observa em corpo/mente, bom/mal, presença/ausência, natureza/cultura e homem/mulher. Na leitura de Grosz (1989), o termo 'desconstrução' é usado para descrever o procedimento que pretende interrogar o falogocentrismo de certas obras, dentre elas as de Freud e Lacan; prescreve táticas ou técnicas com fins de revelar as pressuposições metafísicas que estruturam o binarismo opositivo nos quais se baseia a construção dos textos, tais como: a reversão dos termos entre os polos positivo e negativo (que por si só não basta, pois nos manteríamos dentro do logocentrismo); movimentação e deslocamento ininterruptos próprios à criação das oposições binárias; a emergência de um terceiro produzido como excesso ou dejeto que resiste ao imperativo daquela organização. Os movimentos da desconstrução partem de dentro, o elemento que desestabiliza as estruturas não é externo, mas se produz como um resto não passível de representação. Pretende-se escancarar os pontos de vulnerabilidade e não identidade, subverter limites e trazer à luz a estratégia de dominação condizente à tenacidade histórica que engessa o pensamento ocidental, com fins de reverter o logocentrimo.

Com o termo 'falocentrismo' — ou 'falogocentrismo' - evidencia-se o falo como operador central do sistema patriarcal que prescreve o lugar de submissão das 
mulheres. As representações do feminino são as que os homens decretam, sejam elas inferiores - quando comparadas às representações do masculino a partir de termos comuns - ou complementares, o que pressupõe uma relação entre os sexos que faria um. Segundo Grosz (1989, p. 29), a desconstrução é associada ao longo da obra de Derrida a diversos nomes, dentre eles différance, "suplemento" e "Mulher", apontando ao mesmo tempo para a falta e o desmedido, movimento que estorva o sujeito enquanto senhor do seu discurso: "Mulher representa um resistência, um lócus de excesso dentro de textos logocêntricos/falocêntricos, funcionando como um ponto no qual o texto se volta contra si próprio" (GROSZ, 1989, p. 33), problematizando a diferença sexual e as identidades sexuais tal como previstas pela estruturação binária. Assimilar a noção de différance também marca uma diferença estratégica dentro do feminismo francês — não é igualdade frente os homens que ela sustenta nem uma possível definição do que seria a mulher; pelo contrário, o que se pretende é frustrar tal empreitada.

O feminismo francês não se pautou tão fortemente pelo marxismo e pelo liberalismo como o feminismo Anglo-saxão da segunda onda. Interessa ao primeiro a associação entre linguagem e representação com a produção da subjetividade. À investigação do sexismo da língua, ao estudo das palavras e convenções gramaticais e sintáticas, adiciona-se a interpelação da estrutura da linguagem, tida como falocêntrica, e seu atrelamento à constituição do sujeito enquanto sexuado. Tem-se, então, como horizonte de Irigaray, Cixous, Montrelay e Kristeva a concepção de certo tipo de escrita ou de texto não exclusivamente regido pela ordem simbólica, movido por experiências do corpo, cujos efeitos se fariam sentir na desestabilidade das identidades e na renovação do cenário social, e que Wittig quer desligar do "feminino".

\subsection{Irigaray e a batalha pela diferença}

"A diferença sexual representa uma das questões ou a questão a ser pensada em nossa época. Cada época - de acordo com Heidegger - tem uma coisa a pensar. Uma somente. A diferença sexual é provavelmente aquela do nosso tempo. A coisa do nosso tempo que, pensada, promover-nos-ia a «salvação»?"

— Luce Irigaray (1984/1993, p. 13; trad. nossa) 
Luce Irigaray (1932-) é filósofa, linguista, psicanalista e um dos nomes de maior expressão do feminismo francês. Seu trabalho está imerso na história da filosofia, indo dos pré-socráticos até os pós-estruturalistas. É marcante e conflituosa a relação que mantém com Freud e Lacan. Ao mesmo tempo em que concorda com alguns pontos e incorpora certas ideias — o sujeito é o sujeito da linguagem, por exemplo —, joga a psicanálise contra ela própria para denunciar seu ranço patriarcal.

Em 24 de março de 1965, Irigaray participa ativamente, ao lado de Jean Oury e Jean-Paul Valabrega, do debate fechado intitulado "A propósito da comunicação de Serge Leclaire de 1965: Sobre o nome próprio”, a constar no Seminário XII de Lacan - que, por sinal, ao lado do próprio Leclaire, também fez parte da discussão que girava em torno do estatuto do nome, do nome de família, das suas relações com o imaginário, o simbólico e o corpo. Irigaray também se faz presente no Seminário XIV, na lição de 1 de fevereiro de 1966, agora junto de Lucien Mélèze e Jenny Aubry, em discussão com Jakobson e Lacan. Ela levanta questões sobre a diferença entre sujeito do enunciado, sujeito da enunciação e shifter. Mas o tom colaborativo e cordial entre Irigaray e o lacanismo se encerra anos depois. A publicação de seu primeiro livro, fruto de sua tese de doutorado - Speculum: de l'autre femme, de 1974 —, que lhe deu notoriedade nos círculos feministas, acabou resultando na sua expulsão da École Freudienne de Paris, fundada por Lacan, e a impediu de dar continuidade ao ensino universitário que empreendia em Vincennes ${ }^{2}$. Contudo, hoje em dia seu trabalho tem o devido reconhecimento dentro e fora da França - é imensa a influência que exerceu sobre Butler e Braidotti, por exemplo. Também é tida como um dos grandes expoentes, ao lado de Cixous, do movimento francês da "escrita feminina".

Questionar a espoliação da mulher põe em xeque não só questões econômicas, sociais e morais, mas, sobretudo, a partir de como se deu a fundação de nossa ordem cultural e social, todo um domínio que foi monopolizado pelo homem, toda linguagem prescrita pelo sistema patriarcal. Irigaray tem o projeto de iluminar o feminino entendido como o ponto cego do discurso filosófico, discurso esse que também estaria na base do discurso psicanalítico, marcado pelo falogocentrismo.

Sistemas falogocêntricos se apoiam numa lógica da identidade fundada na exclusão e na polarização binária da diferença. Essa forma de pensamento estaria na base do patriarcado, no interior do qual o homem é identificado com o significante

\footnotetext{
${ }^{2}$ Cf. <www.iep.utm.edu/irigaray>. Último acesso em: 27/03/2014.
} 
fálico e a mulher não é passível de representação, negando ao feminino qualquer protagonismo ontológico. A mulher não é entendida em seus próprios termos, ou positivamente, mas sempre a partir da negatividade do homem.

A proposta de Irigaray de derrocada do falocentrismo também teria repercussão na clínica psicanalítica em termos práticos; incidiria na qualidade da escuta do analista e no manejo da transferência, tal como elabora nos textos "The limits of transference" e "The gesture of psychoanalysis" — ambos publicados em Whitford (1991).

Irigaray é veementemente contra a estagnação da psicanálise institucionalizada. A recusa da psicanálise de analisar politicamente suas estruturas só endossaria a cega submissão ao discurso institucionalizado de poder, que, para Irigaray, segundo Gallop (1982, pp. 94-5), teria reflexos inclusive na prática clínica dos psicanalistas que se adequam a esse tipo de formação - como reflexo, eles tenderiam a submeter seus pacientes à mesma relação de subserviência que aqueles manteriam com seus mestres de escola, assujeitando-os aos significantes deles. Daí Irigaray propor maneiras de inovar a técnica da psicanálise como forma de resistência. Kristeva também criticava as instituições psicanalíticas ao decretar as representações que julgam corretas a respeito de conceitos psicanalíticos, submetendo os analistas inconformados a um exercício de poder segregador.

Ainda nessa perspectiva de análise da política interna à própria instituição psicanalítica, Lisa Jardine (in BRENNAN, 1997) considera que as mulheres não tinham voz lá dentro, que elas não participavam da transmissão da teoria naquela época: atestaria tratar-se de um espaço também hierarquicamente dominado pelos homens. Não à toa, Luce Irigaray foi expulsa e adota tal estratégia: "a mulher analista deixa o seminário do Mestre e começa a produzir um modelo teórico de um imaginário feminino alternativo" (JARDINE in BRENNAN, 1997). Ou seja, o passo dado pelo feminismo francês era político na medida em que angariava um espaço outro também dentro da teoria - surgem muitos livros nos anos 1970 e 80 escritos por mulheres para contar, inclusive, a sua própria experiência de psicanálise (JARDINE in BRENNAN, 1997, p. 12), e também como forma de embaralhar o privado, lugar social relegado à mulher, e o público, privilégio do homem. O social e o simbólico deveriam ser revistos para receber o corpo feminino, assim como o corpo da teoria psicanalítica deveria ser modificado ou acrescido de elementos para recebê-lo. 
Irigaray também é conhecida pela opacidade e complexidade de sua escrita, o que lhe rende muitas críticas, inclusive dentro do universo feminista. Pode-se considerar que seu estilo - muitas vezes poético, e que traz reiteradamente trechos inteiros de textos de autores que lhe são caros - é como uma ilustração de sua estratégia em prol de mudanças. Para Geerts (2010-11), ela procura escrever como um psicanalista escreveria, em colaboração com o analisante e se furtando da posição de mestre.

Irigaray mantém, ao longo de sua obra, extenso debate com diversos filósofos - como Aristóteles, Platão, Descartes, Spinoza, Kant, Hegel, Merleau-Ponty e Levinas - a respeito da elisão do feminino no pensamento ocidental. É notável o seu esforço em demonstrar o quanto, na cultura ocidental, a figura da mulher é associada à matéria, carne, sexo e à natureza, só lhe sendo possível aproximar-se do status de sujeito ao assimilar aspectos da masculinidade. Ela que sempre foi posicionada como objeto, enigma a ser abordado somente em referência aos valores do homem, e não a partir de suas especificidades.

Neste trabalho, limitar-nos-emos à relação que Irigaray trava com a psicanálise. Ela se empenha em denunciar as bases masculinas e opressoras presentes nas obras de Freud e Lacan ao incorporem acriticamente a estrutura do pensamento falogocêntrico. Importante lembrar que Irigaray dedica grande parte de sua obra ao questionamento do sistema simbólico, que ela considera ter sido inaugurado à medida que os corpos das mulheres passaram a ser encarados como valores de troca. $\mathrm{O}$ tabu do incesto teria "criado" a possibilidade de as mulheres deixarem o ambiente privado e serem trocadas por outras. Mulheres como commodities dos homens, sujeitos produtores. "O não acesso das mulheres ao simbólico é o que estabeleceu a ordem social” (IRIGARAY, 1977/1985, p. 189).

Como forma de combater tal sistema, Irigaray desenvolve um método sustentado na noção de mimesis, na reconfiguração da relação mãe-filha, em inovações teóricas como a "simbolização dos dois lábios", chegando até a propor uma revolução no campo da linguagem via imaginário e simbólico femininos, nos quais outra lógica operaria. 


\subsubsection{Contra Freud}

Em sua crítica a Freud, desenvolvida principalmente em Speculum: de l'autre femme e "Ce sexe qui n'en est pas un", Irigaray se foca nos textos "Três ensaios sobre a teoria da sexualidade" (1905), "A organização genital infantil" (1923), "A dissolução do complexo de Édipo" (1924), “Algumas consequências psíquicas da distinção anatômica entre os sexos" (1925), "Sexualidade feminina" (1931) e "Novas conferências introdutórias sobre a psicanálise - conferência XXXIII, feminilidade" (1932-33). Nessa empreitada, Irigaray (1977/1985, p. 49) se mune dos trabalhos de Melanie Klein, Ernest Jones, Helene Deutsch, Jeanne Lampl-de Groot, autores que valorizaram a fase pré-edípica, período ainda não governado pelo falicismo na evolução sexual. Também foi marcada por Karen Horney, que se dedicou principalmente ao papel dos fatores socioculturais em jogo para a determinação do que se entende por sexualidade feminina e sua sustentação nos parâmetros masculinos.

A mulher, ao longo da história ocidental, foi vinculada à figura da mãe, sempre referida à natureza, ao corpo e à reprodução; enquanto o homem, à cultura e à subjetividade. A metafísica de Platão teria marcado a concepção ocidental de diferença sexual, o que acabou desembocando na equação mãe-mulher, ou seja, num achatamento do imaginário feminino. A economia masculina prevalecente seria associada ao logos filosófico, reduzindo tudo à economia do mesmo ou ao pensamento simétrico. Tudo passa a ser medido a partir do homem, único sujeito representado filosoficamente. A mulher é um não homem. Nesse sentido, se o discurso filosófico apresenta um estilo lógico, coerente - portanto, masculino - a mulher seria associada aos atributos contrários, como irracionalidade e inconsciência. Para Irigaray, o processo de construção do homem enquanto sujeito exige a exclusão da mulher dessa condição. Não só a subjetividade masculina, mas toda sociedade seria fundada tendo como ponto de partida esse primeiro sacrifício a que as mulheres são submetidas. À mulher só é possível acessar o lugar de sujeito se ela "importar" elementos próprios aos homens. Se os homens são o sujeito e a mulher, o outro, é como se a diferença sexual não existisse. No final das contas, só haveria um sexo - daí a insistência de Irigaray em que o movimento feminista foque a diferença sexual, o que lhe rendeu embates internos: segundo Whitford (in BRENNAN, 1997, p. 147), Irigaray é criticada por suspostamente ter se sustentado num 'essencialismo biológico', dada sua insistência no corpo da 
mulher, e num 'essencialismo psiquíco' — já que sua teoria levaria a crer que ela perseguia um simbólico feminino.

Thomas Laqueur (2001) mostra que, da Antiguidade clássica até o século XVIII, prevaleceu o modelo do isomorfismo sexual, a ideia de que o corpo-homem e o corpo-mulher não eram opostos anatomofisiologicamente. Nesse período, a fronteira entre o masculino e o feminino é de grau, e não de espécie. O corpo da mulher era uma versão do corpo do homem, o que fazia com que a vagina fosse vista como um pênis invertido. Freud parece herdeiro desse modelo isomórfico, mas em outra entrada. Os corpos são distintos anatomicamente, sim; mas é só a partir de um determinado momento, e sob certas condições, que tal distinção é efetivada. Psiquicamente, até o fim do percurso edípico não há diferença sexual. Além do mais, a libido é única, masculina.

Para Irigaray, a psicanálise seria herdeira do discurso filosófico que, desde os tempos antigos, articula-se epistemológica, ontológica e metafisicamente a partir da perspectiva masculina. Tal discurso é regido por processos como analogia, comparação, simetria e dicotomia opositivas: "A diferença sexual é uma derivação da problemática da mesmitude" (IRIGARAY, 1974/1985, p. 26).

É o que vemos em Freud quando tenta explicar a sexualidade feminina sob tais expressões: inveja do pênis, superego fraco, continente negro, menor senso de justiça, menos interesses sociais e menor capacidade sublimatória. É como se a mulher fosse fruto de um desenvolvimento insuficiente ou deformado quando comparada ao que se dá com o homem. Tentando abordá-la através de processos que fossem comuns a ambos, como o complexo de Édipo e a confrontação com a castração, só pôde equalizála a um mistério.

Na leitura de irigarayana de Freud, a anatomia é o destino: Freud teria se pautado em um determinismo biológico a partir do qual a mulher é inferiorizada e seu sexo não tem valor. A distinção anatômica entre os sexos explicaria a diferença na economia psíquica, sendo só o sexo do homem capaz de representação. Freud opera dicotomicamente e, a partir desse pensamento simétrico, a feminilidade será como um reflexo negativamente equacionado à masculinidade. Para que o homem domine essa economia e o processo de especularização seja bem sucedido, é necessário que o seu "outro" seja produzido, seu binário negativo, a ser diferenciado dele e hierarquicamente a ele submetido: 
[a especularização] é uma intervenção necessária, exigida por esses efeitos de negação que resultam de/ou postas em movimento através da censura do feminino, através do qual o feminino será admitido e obrigado a assumir tais posições: ser/tornar-se; ter/não ter sexo (órgão); fálico/não-fálico; pênis/clitóris ou mesmo pênis/vagina; mais/menos; claramente representável/continente negro; logos/silêncio ou tagarelice; desejo pela mãe/desejo de ser mãe. (IRIGARAY, 1974/1985, p. 22; trad. nossa)

O grosso dos paradigmas e dos valores sociais é masculino. É pelo fato de a mulher ser entendida como ontologicamente irrepresentável na época de Freud, para Irigaray, que se passou a dizer, como Beauvoir, que não se nasce mulher, mas torna-se uma - cabendo-lhe, portanto, um caminho mais longo para percorrer para ser mulher, do que ao homem, para ser homem.

Ser mulher anda em paralelo com acessar um prazer tido como tipicamente feminino. Mas o que ela seria antes disso? "Nada” (IRIGARAY, 1974/1985, p. 25), só um menino menor cuja libido deve ser reprimida em direção ao tornar-se mulher.

A menina é um pequeno menino com certos atributos morfológicos a menos. Ela vive de maneira masculina: excita-se ativamente com o clitóris, uma "espécie" de pênis - equação que, por sinal, nunca é bem superada, o que a levaria sempre a buscar substitutos, a ficar na dependência de alguém que supostamente a aliviaria da dor de não o possuir, - e ativamente toma a mãe como objeto de amor. Ao postular que o que caracterizaria a mulher seria a inveja do pênis, Freud, segundo Irigaray (1974/1985, p. 63) não estaria pautado em uma heterogeneidade, mas sim num tipo de negatividade: não é que ela teria outro órgão ou outro sexo, mas sim um não sexo ou não órgão. Definir a sexualidade feminina dessa maneira seria uma forma de dominação, uma estratégia com fins de manter o poder nas mãos dos homens e aniquilar eventuais ameaças, caso a mulher — a partir do que lhe é próprio — acessasse alguma espécie de representação.

Irigaray (1974/1985, pp. 29-30) aponta que não há uma discussão em Freud a respeito de um suposto estágio da vulva, da vagina ou de um estágio uterino dentro da discussão da sexualidade feminina, o que seria tributário de uma suposta especificidade da mulher; ou da peculiaridade do prazer associado à vagina ou ao toque dos seios e dos lábios. Por que a masturbação da menina só é relativa ao clitóris? Freud, na leitura de Irigaray, não diz nada a respeito de outros componentes do órgão genital feminino e de outras partes sensivelmente erogeneizadas - ele amputaria certas regiões da genitália feminina que supostamente teriam menor potencial erótico. Fica difícil entender por 
que, em Freud, a passagem do clitóris para a vagina como principal zona erógena é importante, e Irigaray sugere que o motivo talvez seja a vagina ser um componente da genitália feminina indispensável para o prazer masculino no ato sexual. A inveja do pênis e o valor atribuído a ele também são interpretados por Irigaray de forma invertida e dialética: a inveja do pênis pela menina seria um afeto primordial; é ele que atribuiria valor ao órgão masculino, como se o menino dissesse: "se ela inveja isto que eu tenho, então meu pênis tem valor". Nesse sentido, o valor que o pênis carrega provém do outro. A castração, válida universalmente, é a de um órgão do menino, não é uma castração "dela", a perda de algo do corpo dela.

Consequentemente, para Irigaray, a mulher será o emblema da pulsão de morte percebida com horror, aquele que o olho da consciência recusa constatar a falta ou falha: a castração. Irigaray chama atenção para o fato de o complexo de castração freudiano passar necessariamente pelo olhar: a criança vê a ausência de pênis da mulher, o que sem dúvida provoca uma mudança computada imaginariamente. 'Nada a ver', frente ao que ninguém, nenhuma mulher pode ajudar a menina a encontrar símbolos que valorizem sua genitália.

Na leitura crítica que Irigaray faz de Freud, a inveja do pênis parece ser o representante do desejo feminino de acionar a ordem simbólica; só dessa forma ela entraria no discurso - significado esse amplamente ancorado no padrão fálico. Ela só alcança o campo simbólico ao preço de abrir mão de sua feminilidade.

A castração imputa à mulher somente uma possibilidade, a mascarada, recurso esse que Irigaray afirma proporcionar algum prazer tipicamente feminino (IRIGARAY, 1974/1985, p. 114). Para ela, a construção da máscara se edificaria a partir dos valores que os homens reconheceriam como importantes para uma mulher. Trata-se de um processo fálico e que, no seu desenrolar, exige que a mulher descarte o que, de fato, lhe seria "seu" para corresponder aos padrões masculinos que ditariam como ela deve se dar a ver.

Irigaray considera que a castração feminina não pode ser pensada como o mesmo processo pelo qual o menino passa. Talvez deva ser encarada como a impossibilidade de representar ou simbolizar a relação inicial com a mãe (período préedípico). Talvez sua "mal resolvida" castração, e a concomitante dificuldade de entrar como sujeito nos sistemas simbólicos, tenha a ver com a impossibilidade de metaforizar aquele desejo original fruto da relação mãe-filha. Ao se submeter às metáforas fálicas como um menino, só lhe resta imitá-lo e fazer equivaler seu desejo pela mãe com o 
desejo por uma mulher, e não a um desejar como mulher (a primeira saída pressupõe que as imagens de mãe e de mulher se condensam no mesmo ser; a segunda, não). A não significação da mulher nessa relação mãe-filha promove a depreciação da mãe - e de todas as mulheres, já que castradas — aos olhos da menina (IRIGARAY, 1974/1985, pp. 83-4).

Outro ponto muito criticado por Irigaray é a dicotomia ativo/masculino e passivo/feminino em voga no entendimento freudiano da diferença sexual. Em Freud, na fase pré-edípica, a menina é como um menino pequeno. No estágio sádico-anal, não há diferenciação entre homem e mulher — só há masculinidade — nem entre atividade e passividade. Seu clitóris é fálico e ativo. Ela tem de abandonar o investimento nesse órgão sexual (e seu objeto de amor inicial, a mãe) para desembocar na feminilidade normal, marcada pela erotização da vagina. Caso contrário, seu destino será a neurose ou a masculinização. Irigaray aponta que é só nesse momento posterior que, talvez por imposição de valores culturais, a menina tenha de abrir mão de seu caráter ativo em prol da feminilidade passiva que é esperada dela.

Segundo Irigaray, a construção daqueles binários tem a ver com um saber de época em que a "ciência do sexual" servia de parâmetro, cujos efeitos eram sentidos inclusive nas esferas sociais e econômicas. Atividade era associada ao movimento do esperma na fecundação; ao passo que a passividade, à "espera” do óvulo. Dessa "espera" pelo esperma se deduz a espera pelo homem no ato sexual. O homem é provedor, produtor, e seu espaço — o público — leva-o a sair do seu ambiente original; a mulher é o receptáculo; seu espaço é o privado. Irigaray (1974/1985, p. 19) critica tanto a construção dos binarismos falogocêntricos quanto a suposição de que a natureza determinaria os significados atribuídos a cada um de seus polos.

E mais, Irigaray segue com sua crítica. A mulher seria sempre passiva? Não, só em um ponto ela não é: ela "escolhe" ativamente a posição masoquista, tal como se leria em Freud. Para Irigaray, ela não teria escolha: como deve suprimir sua agressividade por uma imposição social, já que deve ser afetuosa, delicada e dócil, a mulher converte sua libido em impulsos masoquistas, erotizando tal tendência destrutiva (IRIGARAY, 1974/1985, pp. 19-20).

Neurótica, masculinizada ou feminina masoquista. Irigaray parece considerar que, para Freud, toda e qualquer mulher é patologizável, por ser mulher. Patologizar a mulher seria uma forma de adaptá-la à sociedade masculina (IRIGARAY, /1977/1985, 
p. 73). Nem a maternidade - que, em Freud, seria o traço privilegiado e definitivo do feminino - escaparia desse raciocínio.

Na leitura de Irigaray, a feminilidade, marcada pela inveja do pênis, tenderia justamente a desaparecer com a maternidade. Fazer-se de mãe, tomar o filho como substituto do pênis ausente, é um recurso fálico — portanto, não pode ser feminino (IRIGARAY, 1974/1985, pp. 77-8). Fazer-se de mãe não se confunde com a representação da mulher; pelo contrário, é dar ao feminino uma veste encobridora regida pela economia masculina. Só através de repetições, reiterações de representações fálicas, inscritas no e pelo masculino, que ela entra no universo discursivo do Mesmo. Como não é passível de se inscrever na linguagem, ela nada tem a dizer propriamente sobre seu prazer e seu sofrimento. Na sequência, só resta aos seus sintomas, hieróglifos indecifráveis, a inscrição no corpo: a mulher é associada diretamente a corpo — nesse caso, a somatizações enigmáticas e ao teatro - , sempre como objeto de investigação do homem.

Todo esse cenário social, econômico e representacional ao qual a mulher é relegada é necessariamente indutor de sofrimento. Irigaray parece sugerir que muitas das patologias da mulher são provocadas pelo fato de que, para ter inteligibilidade, ela tenha de reprimir sua feminilidade e falar a "língua dos homens".

Neste sentido, e essa nos parece ser a principal crítica que Irigaray endereça a Freud, ela sustenta que os desenvolvimentos freudianos referentes à diferença sexual não deveriam ser encarados como universais, mas sim resultado do caldo histórico e cultural em que estava embebido, uma cultura "hommo-sexual" (IRIGARAY, 1974/1985, p. 103) regida por uma economia patriarcalista de base vitoriana: "o problema é que ele [Freud] falha por não investigar os fatores históricos que regem os dados com os quais ele estava lidando" (IRIGARAY, 1977/1985, p. 70). Freud não teria se dado conta de que havia a tendência, em sua época, de tomar a anatomia como critério de verdade científica irrefutável e universal; ele não teria reconhecido se tratar somente de um discurso dentre outros a prevalecer em determinado tempo histórico. Freud não questiona os fatores culturais que exigiriam que a mulher reprimisse sua libido no seu caminho rumo à feminilidade.

Para falar dela, Freud recorre aos elementos dele; e, nessa comparação hierarquizante, a mulher sempre é inferiorizada. Para Irigaray, a subjetividade feminina não pode ser pensada a partir desse modelo de "um" sexo. Seria graças a esse tipo de movimento histórico-discursivo que as mulheres são vistas pejorativamente. Para que 
mudanças ocorram e a mulher passe a ter existência social, há de se desvincular a mulher da noção de mãe. O corpo e a natureza, elementos associados a ela, devem deixar de ser encarados como entidades pouco nobres a serem controladas, e o homem deve ser "encorporado". Confundidos para mitigar hierarquias, homens e mulheres devem ser reconhecidos em suas vertentes de natureza $e$ cultura.

\subsubsection{Desobedecendo ${ }^{3}$ Lacan}

Irigaray, seguindo Lacan, trata da diferença sexual para além das diferenças anatômicas, cromossômicas ou enquanto papéis de gênero - no caso, a partir de sua inscrição na linguagem. No processo de constituição do ego corporal do estágio do espelho, a função simbólica decorrente da entrada do sujeito no campo do Outro é imprescindível. A formação da imagem do corpo depende da autenticação da linguagem. Contudo - e aqui Irigaray se destaca de Lacan —, notadamente marcada pela cultura ocidental, a construção imaginária do corpo tem a tendência de "ir contra" o corpo das mulheres: o corpo imaginário que domina o que se entende por corpo é o corpo do homem. Identidade e unidade seriam associadas à anatomia masculina - a diminuição da mulher faz com que a constituição de sua imagem corporal sexuada não se dê da mesma forma que a dos homens. As partes do corpo da mulher que denunciam a que sexo pertence tenderiam a ser menos investidas libidinalmente.

Apesar dessa crítica ao imaginário do corpo em Lacan, o principal alvo de Irigaray é o registro simbólico. Para ela, Lacan - mesmo tendo ao seu dispor instrumentos científicos mais refinados, como a linguística estrutural de Saussure padeceria do mesmo erro de Freud ao adotar, também, o modelo de "um" sexo, só que agora pensando a diferença sexual a partir dos recursos simbólicos da linguagem. Lacan teria mantido a mulher presa a uma versão negativa do Édipo e às garras do falo, agora alçado ao status de significante.

Segundo Irigaray, em "Diretrizes para um congresso sobre a sexualidade feminina", Lacan teve o mérito de ter reaberto o debate a respeito da sexualidade da mulher. Evocou novos desenvolvimentos fisiológicos referentes ao "sexo cromossômico", ao "sexo hormonal", ao privilégio libidinal do hormônio masculino; indicou a ignorância que ainda imperava sobre a natureza do orgasmo vaginal e o papel

\footnotetext{
${ }^{3}$ Elizabeth Grosz, uma de suas grandes comentadoras, caracteriza Irigaray como a "filha desobediente" da psicanálise.
} 
do clitóris no investimento nas diferentes zonas erógenas (IRIGARAY, 1977/1985, p. 60). Mas, e é a partir daqui que Irigaray passa a criticá-lo, Lacan teria apontado o quanto é importante não negligenciar a perspectiva estrutural que supostamente já estava implícita nos desenvolvimentos freudianos sobre o complexo de castração. Para se ter uma leitura justa do Édipo freudiano, há de se levar em conta os registros simbólico, imaginário e real. Contudo, para Irigaray, a tradição lacaniana não os balanceou devidamente e o registro simbólico tomou uma dimensão dilatada demais e uma interpretação inadequada.

O Lacan dos anos 50 especifica que o que está em jogo na castração é a operação simbólica paterna que impede que mãe e filho satisfaçam seus desejos de completude fálica. O desejo passa a ser simbolizado através da linguagem: a necessidade é separada da demanda, fazendo com que o falo seja o significante da falta resultante desse processo, o significante do desejo. À mulher cabe "ser o falo". Para tanto, ela deve renunciar a uma parcela essencial da sua feminilidade para a construção, processo fálico, da mascarada: é sendo o que ela não é que ela pede para, ao mesmo tempo, ser desejada e amada. Já do lado do homem, trata-se de "ter o falo". Ela só encontraria o significante do seu desejo no corpo do homem, que hipoteticamente o tem.

Essa formulação de uma dialética das relações, sexualizadas pela função fálica, de forma alguma contradiz a manutenção do complexo de castração da menina de Freud (ou seja, sua falta ou não-ter falo) e sua subsequente entrada no complexo de Édipo — ou seu desejo de obter o falo de quem é suposto o ter, o pai. Dessa forma, a importância da "inveja do pênis" da mulher não é posta em questão, mas é elaborada mais profundamente em sua dimensão estrutural. (IRIGARAY, 1977/1985, p. 62; trad. nossa)

Para Irigaray, o falo, mesmo como significante privilegiado do Simbólico, ainda manteria uma relação insuperável com o pênis; serviria como um instrumento teórico mais aprimorado a reafirmar a submissão e a inferiorização da mulher. Pensar a diferença a partir de um referente único - e que, ainda, é historicamente masculino — é inaceitável para Irigaray. Além do mais, ela critica Lacan em diversos momentos por considerar que o Simbólico "dele" é um registro a-histórico e imutável. Para Irigaray, a linguagem deve ser encarada como maleável, em fluxo e subordinada a relações de poder. Se a cultura ocidental, incluída aí a psicanálise, não entende as mulheres, é porque insiste em manter os mesmos paradigmas falogocêntricos, regidos por leis que se querem totalizantes. 
Irigaray chega a acusar Lacan e seus seguidores de sustentar sua clínica aos moldes de uma ciência rígida e pré-orientada por uma lei universal, o que não era o caráter inicial da prática de Freud:

Freud e os primeiros psicanalistas não atuavam assim, ou não por certo tempo. Para eles, cada análise era uma oportunidade de descobrir uma nova faceta da prática e da teoria. Cada analisante era ouvido como se ele ou ela tivessem novas contribuições a fazer à prática e à teoria. Mas, uma vez que a "ciência" psicanalítica passou a afirmar ter descoberto a lei universal que rege o inconsciente, e cada análise não é mais que a demonstração prática ou a aplicação da lei, o único status que esta nova "ciência" completa pode ter é o de ter dado por encerrada uma era do conhecimento. (IRIGARAY in WHITFORD, 1991, p. 83; trad. nossa)

Podemos dizer, então, que Lacan, na visão de Irigaray, continua se orientando falicamente sob os moldes patriarcais, tanto em sua clínica quanto em sua construção teórica, haja vista o peso que conceitos lacanianos como o Nome-do-Pai e a lei do Pai têm em ambos os contextos. A mulher continua sendo associada ao outro, mesmo que ao Outro da linguagem - campo a partir do qual o sujeito (homem) se fará reconhecer como tal.

Irigaray elucubra se a foraclusão pode ser o mecanismo em jogo para se pensar a mulher, haja vista sua expulsão do universo da linguagem. Sem significante do "seu desejo" ou imagens válidas do seu corpo, "o que a condenaria à psicose ou, na melhor das hipóteses à histeria, pela falta — censura? foraclusão? repressão? — de um significante valoroso de seu desejo "primeiro" ou de seus órgãos sexuais" (IRIGARAY, 1974/1985, p. 55). Assim como em Freud, o aparato teórico de Lacan também condenaria a mulher à patologia pelo fato de ser mulher, agora tomando como terreno a linguagem?

Irigaray não acusa diretamente, mas — quando discorre ácida e longamente sobre Deus e o Pai na filosofia — parece fazer eco o Nome-do-Pai lacaniano, atacando sua onipresença e ditadura, ao afirmar que "o sujeito do discurso é o pai” (IRIGARAY, 1974/1985, p. 308): um pai que não pode ser visto, que nunca tomará vida e vir a existir; que não tem mortalidade, sempre tendo sido pura especulação; um pai cujo efeito, dentre outros, é o de operar a "divisão em dois gêneros, dois tipos de recurso de especula(riza)ção" (IRIGARAY, 1974/1985, p. 308). O pai é pura especula(riza)ção, é especulação e especular, refletindo o Mesmo, o ser e o um. As fantasias do Ser, manipuláveis e fetichizadas, são frutos da "père-version" que compõe as representações. 
“A palavra do Pai domina as organizações" (IRIGARAY, 1974/1985, p. 313), promove a entrada do filho no discurso da filosofia e não aceita nenhuma particularização da forma - é o que permite a economia das representações, o que a torna possível e produz um ideal de gozo.

O logos paterno torna as coisas inteligíveis, faz com que o Outro transforme tudo em espelhos, sendo que "a mãe está no ponto onde tudo isso é produzido, reproduzido" (IRIGARAY, 1974/1985, p. 317). O Pai, imutável e idêntico a si, está fora das recolocações da história. A imagem associada ao pai é uma esfera: perfeita, sem entradas e saídas, reflexiva, eterna, sem começo e fim (IRIGARAY, 1974/1985, p. 321). O Pai é tomado como fundamento da lei, e isso é inaceitável para Irigaray.

\subsubsection{Gozo e A mulher}

O gozo feminino está fora da lei, fora das possibilidades discursivas - a mulher nada tem a dizer a seu respeito —, sendo "suplementar" à economia fálica: Assim Irigaray (1977/1985, p. 96) define o gozo feminino - muito próximo a Lacan.

Contudo, se ela incorpora o conceito lacaniano de gozo (jouissance) por acreditar que, dentre outras alternativas, seria dando vazão a ele, vencendo o que o reprime, que se teria acesso à especificidade feminina, Irigaray continua tecendo suas críticas a Lacan. No capítulo Così fan tutti (IRIGARAY, 1977/1985) ${ }^{4}$, tomando como referência o Seminário XX, Irigaray problematiza a caracterização do gozo feminino de Lacan como inefável, fora da linguagem, inarticulável - mais uma vez, excluído do discurso. A mulher é não toda; todo é o homem, fálico. Como nada é possível de ser dito sobre o seu gozo, a mulher se mantém, mais uma vez, como alguém que não tem nada a dizer sobre o que seria o mais próprio de si. A mulher como o Outro, o homem como o Mesmo: ela, mais uma vez, servindo como "a matriz, útero para os significantes do sujeito" (IRIGARAY,1977/1985, p. 101).

\footnotetext{
${ }^{4}$ Geerts (2010-11) sugere que o título "Così Fan Tutti" (assim fazem todos - masculino ou universal) comportaria um trocadilho a partir de "Così Fan Tutte" (assim fazem todas - feminino) de Mozart, peça na qual dois rapazes decidem testar a fidelidade de suas amadas, que acabam mostrando-se infiéis, deduzindo daí que "todas elas são assim".Nesse texto, Irigaray aplicaria seu método mimético aos próprios termos lacanianos, repetindo suas palavras e ideias com fins de abrir um espaço imaginário próprio às mulheres. Disponível em: $<$ https://www.academia.edu/403078/Luce Irigaray the un dutiful_daughter_of psychoanalysis. A fem inist moving through and beyond the phallogocentric discourse of psychoanalysis>. Último acesso: $29 / 03 / 2014$.
} 
Com outros recursos, mas com a mesma força de denúncia de tal estagnação paradigmática, em "The mechanics of "fluids", Irigaray (1977/1985) considera que toda a ciência pode ser pensada a partir da categoria do sólido, associada à masculinidade; e a dos fluidos, à feminilidade. Nesse contexto, para Irigaray, a formação do ego no estágio do espelho só se "solidificaria" com a entrada do sujeito na ordem simbólica. Antes disso, a criança se veria como uma continuidade da mãe - num momento présimbólico —, indiferenciada, fluida. Só com a incidência do Nome-do-Pai que ela é deslocada do lugar de falo da mãe. Ou seja, há de se romper com a mãe pré-simbólica, associada à natureza-matéria, fluidamente indiferenciada da criança, para passar à cultura - paternalista, simbólica e sólida - e, assim, ter a imagem de seu corpo constituída e se formar como sujeito. O gozo da mulher, nesses termos, é líquido, indefinido e ilimitado (IRIGARAY, 1977/1985, p. 229), excede os parâmetros falogocêntricos e não pode ser guiado somente pelo falo. $\mathrm{O}$ sexo da mulher não é uno; seu gozo explode em várias partes do seu corpo, espelhado de maneira multifacetada, num jogo polimórfico de reflexos, contrário à unidade de especularização — reflexo reto, simétrico e exato do homem.

A mulher não é aberta nem fechada: é indefinida, tem uma forma nunca completa (IRIGARAY, 1974/1985, p. 229). Não é infinita, mas também não é uma unidade; não se pode dizer que ela é isso ou aquilo, o que está muito longe de se dizer que ela é nada. Nenhum discurso daria conta da economia do seu desejo, nenhuma metáfora a completaria. Talvez a mulher se falicize para se relacionar com o homem, solidificando-se. Contudo, "o gozo da mulher excede tudo isso" (IRIGARAY, 1974/1985, p. 229), uma inundação sem contornos discerníveis. Gozo do corpo porque esse é seu espaço próprio? Não, porque ele é excluído do discurso, para Irigaray — que, a nosso ver, mostra-se tão perto de Lacan no entendimento que faz das descrições do gozo feminino; e, ao mesmo tempo, tão distante, por enxergar neles uma suposta tendência a excluir a mulher do universo político-discursivo.

Há de se questionar os pressupostos da produção de discurso e suas determinações sexuais. A psicanálise, em geral, não teria se debruçado sobre o fato da sexualização do discurso (IRIGARAY, 1977/1985, p. 73). A mulher continuaria excluída: trata-se de uma exclusão interna a uma ordem da qual nada escapa: a ordem do discurso (do homem). “À objeção de que esse discurso talvez seja não-todo [pas tout], a resposta será que elas que são não-todas [pas toutes]" (IRIGARAY, 1977/1985, p. 88). Contudo, seguindo sua leitura do Seminário XX, Irigaray aponta que esse não 
todo da mulher, que resiste ao discurso — ou o ser sexuado dessas mulheres —, não pertence ao corpo como se esse fosse sua terra de origem, mas é resultado de uma exigência lógica do discurso. Lógica e coerência previstas pelo fato de que a linguagem existe e que é externa ao corpo. A sexualização da mulher é efeito de uma lógica que requer a existência da linguagem, transcendental ao corpo, mas que precisa ser encarnada; no caso no corpo das mulheres, mais uma vez o receptáculo excluído para que se constitua a integridade do sistema masculino.

Decorre desse processo lógico que as mulheres não formem conjunto, sendo tomadas uma a uma. "A mulher não existe, mas a linguagem existe. Que as mulheres não existem nessa linguagem - uma linguagem - regida por um mestre, que ela ameaça - como uma espécie de "realidade pré-discursiva"? - que perturba sua ordem" (IRIGARAY, 1977/1985, p. 89). Irigaray entende que a "estratégia" de fazer com que as mulheres só possam ser encaradas uma a uma tem como finalidade impedir que a mulher possa conquistar uma representação discursiva ontológica, o que seria uma ameaça ao império masculino.

Irigaray pensa que o falo, atuante sobre o gozo do corpo do Outro, impõelhe "enumeração: um(a) por um(a). As mulheres serão tomadas, testadas, uma a uma, para evitar o nonsense" (IRIGARAY, 1977/1985, p. 98). Localizar o não todo do discurso na mulher é uma forma de fazer com que a falta do indizível seja suportada, dispondo dessa substância chamada gozo. "A falha do acesso ao discursivo no corpo do Outro é transformada nos intervalos que separam as mulheres umas das outras" (IRIGARAY, 1977/1985, p. 98). Nesse sentido, Lacan ter afirmado que as mulheres devem ser tomadas uma a uma seria uma manobra discursiva de poder com a intenção de enfraquecer seu conjunto na luta em se fazer escutar. Parece-nos que Irigaray lê Lacan literal ou concretamente. Se parece funcionar para seus propósitos políticos, pensamos que o imaginariza e não considera muitas outras possibilidades de leitura decorrentes do enunciado "A mulher não existe”, o que será feito por nós adiante.

Ainda segundo Irigaray, ao mesmo tempo em que a mulher não existe, ela sustenta o desejo dos seres falantes chamados homens: ele vai à procura dela, de algo que se situa no discurso, mas ela é não toda, há algo nela que escapa ao discurso. "O homem a procura como ela estando inscrita no discurso, mas como uma falta, uma falha” (IRIGARAY, 1977/1985, p. 89). A psicanálise seria uma teologia negativa: a mulher ou não se inscreve no discurso, ou se inscreve como uma falta, para o homem. 
Como fora da linguagem, pertence ao universo do sensível. Seu corpo é marcado pelo significante do homem, suporte das fantasias dele, onde serão projetados seus objetos do desejo. "Nada a dizer desse gozo; portanto, não gozando. É como ela sustenta, para eles, a dupla função do impossível e do proibido" (IRIGARAY, 1977/1985, p. 96). Seria só através da articulação do seu gozo que a mulher poderia dizer algo sobre seu sexo: à mulher, o gozo do corpo (do Outro); ao homem, o gozo do órgão, gravado na linguagem.

A sexualização da mulher se dá por uma imposição lógica a ser suportada pela função de objeto $a$, resto do corpo, resto da produção das operações da linguagem. Mas se trata de um corpo sem órgãos, que não leva em conta as zonas erógenas tão consagradas pela psicanálise: "A geografia do prazer feminino não é escutada" (IRIGARAY, 1977/1985, p. 90).

E como ela voltará a fazer parte da sociedade dos homens? Acessando o objeto $a$ através do seu filho, mas: "Ah sim...ainda [encore] sem filhos, sem pai?" (IRIGARAY, 1977/1985, p. 94). Antiga equação mãe = mulher? Ela faz do homem, pai, Outro fundante, útero da linguagem. Essa seria a única saída dentro da lei para o desejo feminino. Ao preço de que não seja um sujeito e que o discurso do homem, seu desejo e seu gozo não sejam perturbados.

Só se pode gozar de uma parte do corpo do Outro, e só se goza ao se corporificar de maneira significante; daí o corpo da mulher ser fragmentado, sempre recortado ao se configurar simbolicamente. Esse mais-de-gozar é do corpo, mas do corpo do Outro - mesmo esse gozo a mais está submetido à linguagem. Então não se trata do corpo dela, mas de suportar um funcionamento da linguagem desconhecido ela, ignorante que é nesse quesito. Há um elemento não sabido no Outro, justamente o que produz esse não todo; e se a libido é masculina, é só desse lugar que a mulher é toda, a partir de uma atribuição masculina sobre ela (IRIGARAY, 1977/1985, p. 91). O falicismo compensaria essa crise no discurso, remediaria o Outro ser barrado.

E mais, na leitura de Irigaray, Lacan teria atrelado gozo feminino à patologia:

Se o homem não tivesse que trabalhar e ela se nutrir para procriar, e ter de interromper seu (outro) gozo, ela poderia viver o amor indefinidamente - daí a dificuldade para ela de interromper o ato sexual. Ela sempre quer mais, ainda [encore] escreveu certo psicanalista (notadamente Jacques Lacan) que equacionou esse "mais" 
[toujours plus] a uma patologia. (IRIGARAY, 1977/1985, p. 64; trad. nossa)

Parece que Irigaray entende que Lacan, tomando o gozo fálico como parâmetro, teria considerado que o que foge a ele, no caso o gozo feminino, seria patologizável. Também nos chama a atenção sua associação tão rápida entre gozo, amor e ato sexual.

Resumindo, para Irigaray, à mulher acoplam-se tais predicados: ela sustenta o discurso, ao passo que está fora dele; seu gozo é não todo, estando em parte ausente de si mesma, ausente enquanto sujeito - só lhe restando o "tamponamento" através do objeto $a$ que é seu filho. "Não seria essa uma retomada mais refinada do postulado freudiano sobre a anatomia?” (IRIGARAY, 1977/1985, p. 102). Se A mulher não existe, ela parece só entrar na relação sexual como mãe, discurso repisado na tradição filosófica do qual a psicanálise não se desvencilharia. "Se há um discurso que demonstra isso, é o discurso analítico, por pôr em jogo, aqui, que a mulher só pode ser tomada como quoad matrem. A mulher só entra em jogo na relação sexual como mãe" (IRIGARAY, 1977/1985, p. 102) - esta passagem de Irigaray, que veladamente faz referência ao Lacan do Seminário XX, confirmaria, segundo a autora, a equação mãe $=$ mulher presente também no lacanismo.

E como operar transformações políticas no universo dos gêneros? Uma forma, além das que se podem dar no universo da linguagem, como veremos adiante, seria intervindo na relação mãe-filha: a mãe transmitindo às filhas uma representação diferente do que seja uma mãe, enfatizando que ambos são sujeitos. Freud, na leitura de Irigaray, não fala que a identificação da menina com a mãe tem força menor que a do menino com o pai no fim do percurso edípico. Ele dá a entender que estudar o período pré-edípico poderia ser um caminho promissor, mas obscuro, para o entendimento da feminilidade.

O dito comum de que as mulheres teriam dificuldades de se separar da mãe revelaria um sintoma da posição das mulheres na ordem simbólica, uma dificuldade para a simbolização primária dessa relação originária com a mãe — não se trata daquela ligação fusional entre mãe e filha prescrita por Chodorow, que criaria problemas para a identidade e a individuação da mulher. $\mathrm{O}$ alvo da discussão de Irigaray é a ordem simbólica, que não fornece outro lugar para a mulher que não o da mãe. Outra representação da mulher permitiria que novas alianças fossem estabelecidas entre elas 
— amorosas, inclusive. O retorno ao corpo da mãe proposto por Irigaray, a nosso ver, não seria um desvio do simbólico — pelo contrário, seria uma forma de acioná-lo através da linguagem.

Se não há representação, a perda daquele primeiro objeto de amor não tem como ser enlutada, não há representação do que foi perdido. Cabe lembrar que não é porque o menino tem um pênis e a menina, não, que é mais fácil para ele representar tal perda, mas porque o sistema de representações é fálico e a mulher está fora dele segundo Irigaray. O problema é o registro simbólico, que cria esse sistema discursivo no qual a mulher é tida como falta.

Para Whitford (in BRENNAN,1997), o grande projeto de Irigaray é uma tentativa de efetuar uma mudança na ordem simbólica, analisando como tal registro opera e expondo seu viés patriarcal. Como reverter o quadro da inexistência de representações linguísticas ou simbólicas da mulher? A estratégia é de um ataque tanto horizontal quanto vertical: lutar por direitos, questionar normas sociais, rever aspectos econômicos, redimensionar a relação mãe-filha e, como condição sine qua non, atuar nos meandros da linguagem.

O sujeito só passa a existir à medida que entra no campo da linguagem. Contudo, a mulher não teria sua subjetividade reconhecida nessa esfera, e a psicanálise, para Irigaray, não resolveu esse problema. A estratégia para a reversão desse quadro não é simplesmente forjar meios de incluí-la, mas alterar a própria linguagem e o seu funcionamento, que se dá através de exclusões constitutivas. A mulher não se torna sujeito da linguagem da mesma forma que o homem; portanto, não se trata de acomodála à linguagem tal como conhecemos. A ordem simbólica, a estrutura sintática e morfológica da língua e as palavras devem mudar.

Há de se examinar as operações gramaticais de cada figura de discurso leis sintáticas, configurações imaginárias, redes metafóricas —, a estrutura da linguagem que fortalece certas representações em detrimento de outras, que produz certos significados e impossibilita outros ${ }^{5}$. Novas palavras devem ser forjadas e usos inovadores devem ser criados para as remanescentes (na língua francesa, por exemplo, o

\footnotetext{
${ }^{5}$ Em Le langage de déments (1973), Irigaray conclui, a partir de dados empíricos, que é muito mais comum homens proferirem "Eu gostaria de ser amado ou Eu digo para mim que sou amado" e mulheres "Você me ama?" (o que equivaleria a "quem sou eu?"). Na primeira, a mensagem é reflexiva, só há um sujeito, que endereça reflexivamente uma dúvida a si próprio. Na última expressão, a pessoa a quem se endereça a mensagem é o único sujeito (IRIGARAY, 1984/1993, pp. 134-5). Neste sentido, o discurso é sexuado e acaba refletindo (ou gerando) os padrões sociais sexuais. Irigaray propõe, por exemplo, que não se diga mais "I Love you", mas "I Love to you", como forma de romper a implicação dicotômica direta sujeito/ativo $(I)$ - objeto/passivo (you).
} 
plural é do domínio masculino; e palavras valorizadas, como sol ou Deus, são masculinas, ao passo que as femininas são menos importantes). Mas esse não é, a nosso ver, o principal motor de transformação do simbólico no projeto de Irigaray: o de maior destaque é o processo de mimesis.

Trata-se de reapresentar, reaplicar às mulheres os estereótipos femininos, de forma que tais estereótipos sejam questionados. Incitar a Verdade, "mais e mais cópia do mesmo" - assim como homem é mais ou menos a cópia da ideia de homem, assim como um infinito reflexo no espelho (IRIGARAY, 1974/1985, p. 291). A imitação infindável sustenta o ideal de uma suposta origem ${ }^{6}$, mas algo sempre escapa e indaga justamente se há origem, ou se só há cópias sem um ponto de partida. Há de se incitar a repetição das visões degradantes associadas às mulheres, também chamada de processo de alimentar o essencialismo estratégico: por exemplo, se a mulher é ilógica, ela deve falar logicamente (atributo associado culturalmente aos homens) sobre sua “ilogicidade". Ocorre que tais repetições nunca são bem sucedidas, nem tudo que é dito ou performatizado a respeito da mulher é passível de ser abarcado - a mulher nunca é aquilo que pode ser dito ou expresso daquela forma, ou é algo a mais. Pretende-se revelar o engodo da economia masculina, que determina os pretensos valores identitários essencializados das mulheres, como se compusessem uma unidade a ser excluída. "Da especularização para o espelho côncavo ${ }^{7}$, no qual as imagens refletidas do sujeito, suas articulações sejam embrenhadas de transformações paródicas" (IRIGARAY, 1974/1985, p. 144). Ou seja, a mimesis é a repetição "irônica" de um atributo negativo associado à mulher com a intenção de revelar que ela não pode ser reduzida a ele, até que tal associação seja descartada. E nessa infindável especularização do ser, cujo modelo define o que é inteligível, "o olho é o mais precioso órgão de compreensão" (IRIGARAY, 1974/1985, p. 333). Ou seja, além das repetições discursivas, incita-se o ato, o que guarda muito parentesco com o ato performativo butleriano e sua concepção de paródia de gênero.

Com a indução da mimesis, algo não é absorvido, e Irigaray (1977/1985) localiza aqui o gozo feminino. Interessante que, para Butler, a performance tem caráter

\footnotetext{
6 Irigaray associa "origem" à ideia de um Deus transcendental - cuja origem, justamente, é desconhecida. Ela a relaciona à imagem de perfeição, de harmonia do Universo, à imagem de um Deus que todos imitam, ao passo que ele próprio não imita ninguém. Deus-Pai incita a repetição do mesmo, seu ponto de vista organiza o mundo; para tanto, tem que deixar para trás a natureza, o mundo sensível e, consequentemente, o que se entende por mãe e mulher.

7 "Speculum", que compõe o título da obra Speculum: de l'autre femme, também é instrumento, um espelho curvado, usado pelo médico ginecologista para inspecionar a vagina. Metaforicamente, seria um recurso que permitira à mulher se ver na sua mais íntima particularidade.
} 
ontologizante - pelo menos em Gender trouble —, ou seja, nada escaparia a ela; e Irigaray já tinha antevisto que nem tudo é "performatizável", no caso, o gozo feminino.

Para Irigaray (1977/1985, p. 78), há de se quebrar o espelho fálico que induz especularizações no discurso, destruir o maquinário teórico que tem a "pretensão de produzir uma verdade e um significado que seja excessivamente unívoco". Pretende-se deixar de balizar-se pela economia do logos. A ideia não é produzir uma lógica feminina discursiva com fins de se opor à masculina, o que só confirmaria e daria ainda mais força ao regime fálico que opera por binários excludentes e hierarquizantes como mente/corpo e homem/mulher.

"Esta outra lógica discursiva deixaria de privilegiar o "próprio" em benefício do "próximo" não (re)capturado na economia espaço-temporal da tradição filosófica" (IRIGARAY, 1977/1985, pp. 153-4). Implicaria uma relação diferente com a alteridade, a verdade, o mesmo e a repetição - contra a especula(riza)ção do espelho plano, a favor do espelho côncavo, perturbando a exclusividade dos referenciais masculinos. Mas como? Através de uma reformulação do espaço e do tempo. É necessária outra forma de se encarar o espaço e o tempo para que o gozo da mulher tenha lugar.

\subsubsection{Topologia}

"A passagem para uma nova era só será possível
com uma mudança na nossa percepção e
concepção do espaço-tempo, habitação dos lugares
e de envelopes de identidade. Isso assume e causa
uma evolução ou uma transformação das formas,
das relações da matéria com a forma e do
intervalo entre: a trilogia da constituição do lugar.
Cada era inscreve um limite para essa
configuração ternária matéria, forma, intervalo, ou
poder (puissance), ato, intervalo intermediário." — Luce Irigaray (1984/1993: pp. 7-8; trad. nossa)

Tradicionalmente, a mulher dimensiona o lugar do homem, estabelecendo os limites. Talvez, reconsiderando essa concepção de lugar, entrássemos em outra época da diferença, já que cada época do pensamento adota um tempo de mediação sobre ela. Modificando as relações entre forma, matéria, intervalo e limite, uma relação entre dois 
sujeitos amantes de sexos diferentes talvez fosse concebível (IRIGARAY, 1984/1993, p. 12).

Nessa empreitada será necessário um terceiro termo; caso contrário, correrse-ia o risco de um dos binários envelopar o outro, engoli-lo. "Talvez em direção a uma era em que o tempo vá reimplantar o espaço, redesenhar a imanência e a transcendência, notadamente a partir de um limiar nunca antes examinado: o sexo feminino" (IRIGARAY, 1984/1993, p. 18). A mulher seria o terceiro termo a desbancar a lógica falogocêntrica. Irigaray aponta, metaforicamente, que aquele limiar é semiaberto, como os lábios e o órgão sexual feminino. Destaca-se o "entre", circular, sem se saber onde começa e acaba; estranho, então, a dicotomias e oposições - como a do dentro/fora topológicos.

Mas não seria dessa forma que o "sujeito-mulher" seria representado logicamente:

\begin{abstract}
A topologia do sujeito tal como é definida por certos teóricos da psicanálise (como Jacques Lacan) e certos lógicos toma o solo ou substrato simbólico no qual o feminino está a serviço do sujeito masculino. Como o sujeito funciona de acordo com a banda de Moebius, indo de fora para dentro e de dentro para fora, sem mudar de borda, isso encerraria o ciclo do amor entre mãe e filha e entre as mulheres. Nessa clausura topológica, que não é aberta, o sujeito reprime-se, não é livre no que poderia vir a se tornar, a mulher é trancada neste "feminino-maternal", [...] e o que escapa a isso é repugnado. (IRIGARAY, 1984/1993, p. 105; trad. nossa)
\end{abstract}

Contra o encarceramento do "sujeito feminino" à banda de Moebuis, na qual um lado corresponde à mulher e o outro à mãe, figuras indissociáveis e indiscerníveis, Irigaray (1984/1993, p. 109) passa a considerar que a mulher deve construir um mundo em suas três dimensões.

A partir das considerações de Aristóteles sobre o lugar, Irigaray pensa que o lugar é, ao mesmo tempo, dentro e fora, ou que a mesma causa não atua da mesma forma dentro e fora, podendo haver uma reversão de envelopes - o que permite pensar em seu caráter de reversibilidade, torção e crossing-over [recroisement] (IRIGARAY, 1984/1993, p. 41). Isso nos soa como se Irigaray estivesse propondo que a diferença sexual fosse pensada a partir da topologia do cross-cap ou da garrafa de Klein ${ }^{8}$. Desde

\footnotetext{
${ }^{8}$ Neste ponto, Bruce Fink se aproxima de Irigaray: "O que nos interessa na forma lacaniana de definir a estrutura masculina e feminina? Em primeiro lugar, ela envolve uma nova topologia: ela rompe com a antiga concepção ocidental de um mundo como uma série de círculos ou esferas concêntricas, e por sua
} 
que o envoltório não é nem seu conteúdo nem seu continente, o lugar não é nem a matéria nem a forma: o sexo feminino não é matéria nem forma, mas envoltório.

Contudo, mesmo quando Lacan passa a fazer mais uso de recursos da topologia, na vanguarda do discurso psicanalítico, e aponta que a relação sexual não existe, Irigaray tem lá suas questões. Ainda assim se estaria no campo do Outro do Mesmo, do discurso da verdade e da demonstração. Falar que não há relação sexual "não equivaleria [a dizer] que não há relação sexual possível, já que não há saída do logos, que é totalmente assimilado ao discurso do conhecimento?" (IRIGARAY, 1977/1985, p. 99). Mais uma vez, a psicanálise e seu afã universalizador e ahistoricizante — só que agora privilegiando o demonstrável e o formalizável — perpetuariam a economia logocêntrica.

Irigaray questiona se a psicanálise poderia lançar mão de outra lógica, que dispensasse a mestria. O risco é que, "sendo a relação sexual impossível, [...] que se continue criando leis dessa própria impotência, e permanecer subjugando as mulheres" (IRIGARAY, 1977/1985, p. 105). Irigaray associa o aforismo "não há relação sexual" com o discurso do conhecimento ou do mestre que, em âmbito social, obscurece a mulher - para nós, ele deve ser pensado ao lado do discurso do psicanalista, como veremos adiante.

Também indaga como aquelas propriedades do fluido, historicamente relegadas ao feminino, podem ser usadas para se pensar a diferença sexual e a imagem associada a ela, contra a especula(riza)ção que subentende a estrutura do sujeito. Considerações da matemática pura teriam impedido a análise dos fluidos, restringindose aos termos de planificação.

Propaga-se, então, a ideia de que as mulheres não são bem compatíveis com os quadros simbólicos, suas leis e seus sólidos princípios, mas sim próximas a uma agência que tenderia a perturbar tal ordem — no caso: o registro do real, que confunde as fronteiras e resiste a ser incorporado. Ao real, Irigaray associa as propriedades dos fluidos, que funcionariam como uma aporia na formalização matemática.

A mulher opera como um mapa projetivo, com propósitos geométricos com fins de garantir a totalidade do sistema (ou do conjunto dos homens), avaliando o "todo" da extensão de cada um de seus conceitos, incluindo aqueles que ainda são indeterminados; serve como os intervalos fixos e congelados entre suas definições da 
linguagem, e como a possibilidade de estabelecimento das relações individuais entre eles. A mulher serviria de "ligação copulativa" na proposição. "Tudo isso só é realizável pela virtude de sua característica "fluida", que, por outro lado, retira-a de toda possibilidade de se identificar a tal lógica” (IRIGARAY, 1977/1985, pp. 108-9). Apesar de ter sido alvo de formalizações exaustivas, estas excluem de seu modo de simbolização "certas propriedades dos fluidos reais" (IRIGARAY, 1977/1985, p. 109) — no caso: uma dinâmica, pressão e movimento específicos associados à mulher.

Qual a importância disso para a psicanálise? Metonímia (fluido) passa a ter mais privilégio que a metáfora (quase sólido); desbancam-se dicotomias opositivas e categorias metalinguísticas. O sexo feminino seria um excesso à boa forma, boa forma essa que alicerça circuitos fechados como o princípio da constância ou a repetição do estado de equilíbrio. Irigaray chega a considerar que o próprio objeto $a$ é do universo dos fluidos - ter sido associado a matérias sólidas, como às fezes, é um exercício de dominação, tentativa de enquadrá-lo nos meandros da racionalidade. O objeto $a$ seria mais próximo das propriedades dos fluidos como urina, saliva, luz, onda, perfume, plasma (IRIGARAY, 1977/1985, p. 133). Fluido, a-forma, outra lógica: feminino.

\subsubsection{Kiss my lips}

Como reescrever o símbolo fálico? Para ir contra o falogocentrismo que permearia o entendimento lacaniano da diferença sexual, Irigaray propõe, ironicamente ou não, a simbolização ou a metáfora dos dois lábios, que permitira a construção de um imaginário feminino, atestando a especificidade das mulheres. Este símbolo dos dois lábios não seria regido pela lógica fálica estática e sólida, o que levaria as mulheres a falar de sua especificidade, de sua pluralidade, de seu caráter de abertura e movimento, sempre se tocando, contra a imagem estática do pênis. Através desse tipo de simbolização, a mulher teria acesso a seu próprio imaginário e a woman-to-woman language adviria, restituindo às mulheres seu lugar no discurso e sua posição de sujeito.

Não estaria Irigaray sendo aqui essencialista? Para alguns, tratar-se-ia de uma estratégia política, na qual a ironia é fundamental, com fins de abalar o estandarte fálico do seu posto de comando hierarquizante e afastar o perigo sempre circundante de sua equação ao pênis. Seria como adotar um essencialismo feminino com fins meramente estratégicos (lábios da boca-lábios vaginais $=$ mulher $\mathrm{X}$ falo-pênis $=$ homem). Além do mais, não há hierarquia entre os lábios, como ativo e passivo, nem 
são regidos pelo olhar (aqui Irigaray dialoga com Merleau-Ponty, mostrando a importância exorbitante que a nossa cultura atribui ao visível), mas pelo toque.

O tocar-se seria primário, anterior ao ver/ser visto; segue uma lógica ou uma lei não totalizadora, como se dá com a visão. Não se trata de uma lei excludente, isto ou aquilo: dois lábios, formando um círculo, permitem, por exemplo, a ideia de ser mulher e mãe (IRIGARAY, 1984/1993, p. 167). Não existe mestria entre eles, nem oposição. Importante frisar que não se trata aqui da oralidade freudiana. É algo anterior à formação do sujeito e a qualquer articulação da linguagem, o outro (ainda) não foi tomado como objeto de discurso.

Irigaray considera que as mulheres são detentoras de múltiplas zonas erógenas, cada uma podendo lhes proporcionar um tipo de prazer diferente; e que, por ser exigido delas que se adequem à economia fálica, tais zonas, e suas diversas possibilidades, passam a ser restritas — ou mesmo inexploradas. $\mathrm{O}$ sexo da mulher não é "um", os dois lábios podem ser vistos como plural, sempre se tocando, rompendo a lógica binária falocêntrica que divide o mundo em sujeito/objeto, ativo/passivo, tocante/tocado (GEERTS, 2010-11, p. 19).

Esta longa citação parece resumir esse momento irigarayano:

À mulher não é possível atribuir um significado fixo pelo discurso de forma a lhe imputar um conceito ou alguma noção fixa. Mulher não é relacionada a um ser simples e designável, sujeito ou entidade. Nem é um grupo completo/inteiro [chamado] mulheres. Uma mulher + uma mulher + uma mulher nunca será somada para compor uma entidade genérica: mulher. A/uma mulher se refere ao que não pode ser definido, enumerado ou formalizado. A mulher é um nome comum pelo qual nenhuma identidade pode ser definida. A/uma mulher não obedece ao principio da identidade do eu, no entanto a variável $\mathrm{x}$ em si é definida. Ela é identificada com todo $\mathrm{x}$ variável, não de uma maneira específica (de uma maneira particular). É pressuposto um excesso a toda identificação egóica. Mas esse excesso (não) é nada: é o espaço vazio da forma, falha da forma, retorno para outra borda na qual ela se re-toca com a ajuda de - nada. Lábios da mesma forma - mas de uma forma que nunca é simplesmente definida - se transbordando e se tocando e se reenviando num curso que não se fixa a uma única configuração. Isso já tomará lugar sem o consentimento ou o assentimento de qualquer objeto ou sujeito. [...] Outra (topo)-logia do gozo. (IRIGARAY, 1974/1985, pp. 229-230; trad. nossa)

A topologia do gozo da mulher tem a ver com o toque e o formato dos lábios, sustenta-se em uma lógica que está além dos pares de oposição. Por fim, Irigaray pensa que tentar definir a sexualidade feminina é um projeto malogrado: procurar 
definições ou forjar identidades é algo que pressupõe a ordem do ser, o sistema de representação metafísico masculino, o que acaba igualando outridade e mesmitude, firmando a repetição da alteridade do mesmo nos moldes do eu, "ao que ela responde: não...ainda (em francês "encore"). E de fato, em um sentido, nesse sentido, nunca" (IRIGARAY, 1974/1985, p. 232).

Ainda como forma de alimentar todo esse debate, podemos indagar sobre o que se trataria na proposta de postular um "imaginário feminino", tal como se lê em Irigaray. Não seria autocontraditório? Se pensarmos que imaginário e identidade têm parentesco, proclamar um imaginário feminino seria próximo a conceber uma identidade feminina, o que cai na armadilha falogocêntrica de edificação de identidades: tratar-se-ia de uma definição masculina do feminino. Mas podemos pensar de outra forma: o imaginário feminino pode ser equacionado ao inconsciente do pensamento ocidental, o que não pode ser simbolizado pela filosofia, restos, fragmentos da estruturação imaginária da ordem simbólica dominante (masculina). Não estaríamos falando do "inconsciente feminino", desta ou daquela mulher, mas de como o registro imaginário poderia transformar o registro simbólico - um não tem como ser pensado sem o outro - e, a partir daí, mudar a fantasia social e filosófica atribuída às mulheres e suas encarnações concretas.

O simbólico, dentre outras funções (entrada no social, na linguagem, constituição do sujeito e do campo do desejo), permite a ruptura com o imaginário. "O simbólico que vocês impõem como universal, livre de qualquer contingência empírica ou histórica, é o imaginário de vocês transformado numa ordem, uma ordem social" (IRIGARAY apud WHITFORD,1997, p. 161). Ou seja, o problema não é o simbólico em si, mas como o falogocentrismo ocidental (e a psicanálise lacaniana) molda o simbólico. Como o imaginário masculino acaba por lê-lo e formatá-lo. Nessa interpretação, segundo Withford (in BRENNAN, 1997, p. 160), a proposta de Irigaray seria a reestruturação ou reconfiguração do simbólico via imaginário: revertendo as fantasias sociais impostas às mulheres, as representações simbólicas e o lugar que ocupam dentro do simbólico seriam modificados.

Também há de se pensar sobre o entendimento do que seja "diferença". Ao longo dos tempos, a diferença foi concebida de formas diversas. A ideia que temos de diferença decorre do que o falogocentrismo permite que se pense sobre ela. Como seria pensar a diferença em outro registro, sob a égide de outra lógica, não planificada? A diferença a partir da garrafa de Klein? A diferença a partir do mecanismo dos fluidos? 
A diferença pode ser pensada em dois níveis em Irigaray: no nível diagnóstico - quando, por exemplo, atesta que em psicanálise só há indiferença sexual —; e no político, que aponta para a positividade da diferença (ao contrário da diferença negativizada pela psicanálise, como falta) e sua constante abertura para o futuro, como processo de diferenciação constante. Contudo, e ao mesmo tempo, trata-se de uma política que vai contra construções identitárias (GABRIEL, 2009, pp. 39-40). Que tipo de diferença seria essa, essencializada e nunca neutra - para assim permitir o advento da mulher - ; e, ao mesmo tempo, não identitária? Uma diferença que traz em si o potencial de produzir diferença.

[...] para Irigaray, é improvável que o simbólico, ou seja, aquela ruptura com o imaginário na qual o individuo é capaz de pensar sobre seu próprio imaginário, em vez de pensar por ele, tome uma forma social enquanto não existir outro real. No momento, segundo Irigaray, o que temos é uma economia do semelhante, um intercâmbio entre homens - o mesmo imaginário, masculino, sem coisa alguma para atuar como "ruptura", exceto as mulheres. Ou seja, para que os homens façam a ruptura com o imaginário deles, seria necessário outro termo - a mulher como simbólico. Enquanto as mulheres continuarem a ser dentro daquele imaginário, elas não podem ser o termo que efetua a ruptura. (WHITFORD, 1997, pp. 162-33; trad. nossa)

A mulher engendra uma diferença diferente. A mulher a ser o emblema da différance derrideana. A mulher efetuará a ruptura. Quando? Onde isso já aparece? Onde se lê. Na "escrita feminina".

Irigaray comenta a representação do gozo feminino a partir da estátua de Bernini de Santa Teresa, que ilustra a capa do Seminário XX de Lacan: "Em Roma, tão longe, uma estátua, feita por um homem? Feita para ser olhada? Para saber do gozo de Teresa, talvez seja melhor recorrer a seus escritos. Mas como lê-la quando se é homem?" (IRIGARAY, 1977/1985, p. 91).

A escrita feminina derrocaria a rápida identificação da mulher com o buraco do discurso, e a estratégia adotada não seria reverter o domínio masculino, movimento esse que só fortaleceria o falocentrismo, mas de praticar a diferença regida a partir de dentro de outro sistema. Trata-se de experienciar a diferença de uma maneira diferente daquela concebida a partir da linguagem moldada pelo masculino.

Falar (como) mulher ("parler-femme") e escrever (como) mulher. A escrita necessariamente provoca outra economia do sentido. Mudando a forma de escrita ou o 
discurso lógico, outros significados seriam atribuídos às mulheres. "[...] o feminino é sempre afetado por e para o masculino. O que queremos pôr em jogo é uma sintaxe pela qual as mulheres possam se autoafetar" (IRIGARAY, 1977/1985, p. 132). Autoafetar e tocar-se são modos de significação em conformidade com o não fechamento feminino — aqui se faz necessária outra sintaxe da língua e outra gramática da cultura.

Em 1974, ano de publicação de Speculum: de l'autre femme, a revista L'arc — de grande expressão na cena intelectual da Paris da época - estampa na capa de sua quinquagésima oitava edição o busto de Lacan. Curiosamente, todos os textos são assinados por mulheres, dentre elas Irigaray, Montrelay, Manonni e Dujardin - um volume que se dedica a temas de interesse das mulheres e que também toma Lacan como assunto, "a real ladies man" (GALLOP, 1982, p. 33). Mas, em grande medida, as feministas ainda insistiam, munidas da desconstrução derridiana, no caráter falocêntrico do lacanismo. O que será que quer dizer, nesse momento de ebulição do feminismo francês e do essencialismo irigaraiano, Lacan declarar "A mulher não existe”?

\subsection{Cixous e a escrita transformadora}

"Aqui encontramos o inevitável homem das pedras, sustentando-se ereto em seu antigo reino freudiano, na maneira em que, para recuperar a velha figura do ponto em que a linguística é conceitualizada como "revigorante", Lacan a preserva no santuário do phallus ( $\phi)$, "protegido" da falta referente à castração. O "simbólico" deles existe, ele detém poder."

— Hélène Cixous (1975/1981, p. 255; trad. nossa)

Hélène Cixous é professora universitária, poeta, filósofa, dramaturga, crítica literária e feminista nascida na Argélia, em 1937. Escreveu diversas peças de teatro, ficções e ensaios. "No final dos anos 70 e durante os anos 80, Cixous se tornou uma das feministas francesas mais frequentemente citadas [...], tornou-se mais militante [...] e se associou ao grupo de mulheres "Politique et Psychanalyse" (IVES, 2013, pp. 21-22), comandado por Antoinette Fouque, uma das figuras mais importantes desse cenário. Sua escrita é um complexo de teoria e ficção, de concessões estratégicas e recusas de certas ideias. Cixous também se dedica à desmontagem de poderosas 
narrativas, mitos e lendas presentes na literatura ocidental que acabam por balizar nosso imaginário.

"Le rire de la méduse" (1975), para os nossos fins, é o trabalho de Cixous mais relevante - por ser o que mais abertamente debate com a psicanálise. Seu clima é de uma convocação a que as mulheres recorram a seus corpos como forma de expressão, ao invés de permanecerem enclausuradas pela linguagem opressora estruturada aos moldes masculinos. Esse texto é cheio de alusões literárias e defende um modo feminino e inovador de escrita. Incita-se escrever o corpo: "Se não se escreve, alguém vai escrever (sobre) você [...], você será editada, selecionada, controlada [...]" tal como Ives (2013, p. 40) interpreta a visão de Cixous de seu entorno.

Nunca teria havia no mundo ocidental, segundo Cixous (in MARKS; DE COURTIVRON, 1975/1981, p. 248), uma escrita que inscrevesse a feminilidade. Na sua esmagadora maioria, a escrita era masculina, feita por homens, e as representações das mulheres na literatura provinham do que eles diziam a respeito delas, associando-as a adjetivos como 'sensível', 'sonhadora' e 'intuitiva'. Ou seja, no universo da escrita, também, a repressão e a inferiorização da mulher é perpetuada.

Ao lado de Catherine Clément, Cixous publica em 1975 outra obra de grande repercussão no meio, La jeune Née, propondo que seria através da escrita que a mulher se colocaria por si mesma dentro da história — seja através da identificação com a mulher heroica da ficção, na proposta de Cixous; ou com a histérica e a feiticeira, para Clèment (WRIGHT in BRENNAN, 1997, p. 199) - Dora, paciente histérica de Freud, serviria como representação da mulher que ousou ir contra todo o poder do homem encarnado no mestre de Viena, que pretendeu lhe imputar seu saber, abandonando-o.

A descoberta da obra de Clarice Lispector foi de extrema importância para Cixous, considerada por ela uma escritora que legitimamente manifestava em seu texto a "escrita feminina". Assim como Gide e Beckett, tratava de temas caros a Cixous: a relação entre viver e escrever e o fluxo da linguagem (IVES, 2013, p. 22). Em Lispector, Cixous (cf. Vivre l'orange) confessa ter encontrado o vínculo entre um uso muito peculiar da linguagem e sociedade: "Cixous recorre a Clarice Lispector para ilustrar a conexão entre escritura do feminino e transformação social" (BRENNAN, 1997, p. 32).

Ao lado de Irigaray, Cixous persegue um tipo de escrita que implemente a diferença sem que se acionem oposições hierarquizadas duais, recorrendo também à différance de Derrida, mas expande seu alcance para o teatro. O teatro serviria como 
uma forma de "espacializar" esse tipo de escrita, seria como uma fala escrita que pede troca de subjetividades (SCHIACH in BRENNAN, p. 218) - Cixous cria as peças Le nom d'Oedipe e Retrato de Dora, claramente tomando personagens da psicanálise como tema a ser reinterpretado.

Por sinal, no Seminário XXIII, Lacan aborda essa última peça de teatro de Cixous:

Gostaria de apresentá-los, ou de evocar, para aqueles que já a conhecem, a alguém de quem gosto muito e que se chama Hélène Cixous. Ela já tinha feito, parece, uma notinha sobre Dora em um número esgotado de Littérature, em que eu mesmo lancei "Lituraterra", e depois fez uma peça, O retrato de Dora, que está sendo encenada do Petit Orsay. Achei que não está nada mal. Disse o que pensava a esse respeito àquela a quem chamo de Hélène desde quando a conheci, e lhe disse que falaria disso. (LACAN, 197576/2007, pp. 101-2)

Inicialmente, Lacan comenta a atuação dos atores, e depois trata da histeria ali encenada — "incompleta” (LACAN, 1975-76/2007, p. 102) para ele, já não teria levado em conta que, nesse tipo clínico, é "sempre dois" (LACAN, 1975-76/2007, p. 102) que estão em cena.

Retornemos. Assim como os trabalhos de Irigaray, "Le rire de la méduse" faz duras críticas ao falogocentrismo, tal como concebido por Derrida. Condena-se a lógica binária que opera por oposições entre termos, como masculino e feminino (IVES, 2013, p. 63). Nesse quadro, o que se diz sobre a mulher parte do par de opostos atividade/passividade - assim, a mulher é tida "como continente negro a ser penetrado e pacificado" (CIXOUS in MARKS; DE COURTIVRON, 1975/1981, p. 247). Para que tal empreitada seja bem sucedida, deve-se desterritorializá-la, ou seja, retirá-la do seu corpo. A mulher - seu corpo, sua sexualidade - teria sido reprimida na cultura ocidental e recalcada no interior da psicanálise. O que se diz sobre ela é o que um homem consegue dizer sobre ela, ou seja, quase nada: mistério. Daí a mulher falar de si, escrever sobre si e se inscrever, construir por ela própria uma representação de si. "A mulher deve se colocar em texto - assim como no mundo e na história — pelo seu próprio movimento" (CIXOUS, n MARKS; DE COURTIVRON, 1975/1981, p. 245). O terreno de ação a ser destacado nesse projeto não é o universo econômico ou o mundo do trabalho, mas a sexualidade feminina sempre emudecida.

Para Cixous, não se deve tomar como ponto de partida a visão, ou o registro especular, da anatomia corporal como ponto de partida para se conceber a diferença 
sexual, mas o gozo (jouissance). A questão, para Cixous, é, contudo, onde se localiza esse gozo e como escrevê-lo: "Como eu experiencio meu prazer sexual?... O que é o gozo feminino, onde ele acontece, como ele se inscreve - no nível do corpo dela ou no inconsciente dela? E então, como pode ser escrito?" (CIXOUS, 1975/1986, p. 35). É a escrita desse gozo - do, no e através do corpo - o que retiraria a mulher do silêncio reservado a ela por meio do Simbólico, afirma Cixous nesse texto. Trata-se, então, de criar novas imagens, novas formas de representação da sexualidade; de deturpar regras gramaticais, desrespeitar a sintaxe e toda forma de funcionamento determinado pelo simbólico formatado de modo masculino.

É somente pela escrita, da e na direção da mulher, assumido desaviar o discurso que tem sido governado pelo falo, que as mulheres se confirmarão mulheres em outro espaço que o reservado a ela no e pelo simbólico, ou seja, um lugar outro que o silêncio. (CIXOUS in MARKS; DE COURTIVRON, 1975/1981, p. 251; trad. nossa)

Na proposta de Cixous, é como se o corpo tivesse sido confiscado da mulher no sistema patriarcal; portando, trata-se de repossui-lo. Escrever seria a forma de restituir o que lhe foi roubado: sua voz, sua sexualidade, seu prazer, seu desejo e seu gozo.

O corpo da mulher deve ser liberado; e, para que possa se falar disso, para que possa ser tratado como questão, ele deve se confundir com o texto: sext. Texto e corpo são como que coextensivos - censurar o corpo implica censurar que a mulher possa inscrever-se em texto, como já havia denunciado Irigaray. Escrever seria uma forma de transcendência.

“A escrita é precisamente [o lócus] da possibilidade de mudança, o espaço que pode servir como trampolim para o pensamento subversivo, o movimento precursor da transformação social e das estruturas culturais" (CIXOUS in MARKS; DE COURTIVRON, 1975/1981, p. 249). Para que haja esse tipo de transformação, "a mulher deve escrever através de seu corpo, deve inventar uma linguagem inexpugnável que demole repartições, classes, e retóricas, regulações, códigos [...], a gramática e linguagem dos homens" (CIXOUS in MARKS; DE COURTIVRON, 1975/1981, pp. 256-7).

E na radicalidade de sua proposta, Cixous chega a requisitar outra linguagem para a mulher: 
Se a mulher sempre funcionou dentro do discurso do homem, um significante que sempre se remeteu ao significante oposto que aniquila sua energia específica, que diminui ou asfixia seus sons específicos, é tempo de deslocar esse dentro, explodi-lo (...) e inventar para ela uma nova linguagem na qual se inserir. (CIXOUS in MARKS; DE COURTIVRON, 1975/1981, p. 257; grifo nosso; trad. nossa)

Intervir nos códigos linguísticos, criar novas palavras, alterar sufixos, derrubar regras gramaticais, "escrever e, assim, forjar para ela uma arma anti-logos" (CIXOUS in MARKS; DE COURTIVRON, 1975/1981, p. 250). Ou seja, esse tipo de escrita, assim como descreve Irigaray, não pretenderia edificar essências, uma identidade feminina, já que tal estratégia é falogocêntrica. Há de se ir contra qualquer proposta de fundamentação identitária: é o sistema que deve mudar, não seus elementos.

A proposta é a de uma escrita que desconstrua a linguagem falocêntricapatriarcal, já que "a mulher foi mantida na escuridão no que diz respeito a si, conduzida ao desdém quanto a si graças à grande armada do falocentrismo parento-conjugal [...]". Tal sistema objetivaria formatar o universo pulsional da mulher, "surpreso e horrorizado pelo fantástico tumulto das pulsões dela" (CIXOUS in MARKS; DE COURTIVRON, 1975/1981, p. 246).

Prega-se o retorno ao modo de funcionamento do período pré-edípico como tábua de salvação, um período ainda não submetido à lei e à formatação regulatória que exige a perda do caráter subversivo e disruptivo da pulsão à medida que se dirige à sua finalidade genital.

Esse projeto toma muito cuidado em não cair em outro tipo de "falocentricidade". Pois, caso isso acontecesse, é como se agora fossem as mulheres a reclamar o falo, e não é disso que se trata - mas sim de subverter o mecanismo que opera a lógica masculina. Ao feminino se acoplam o irracional, o intuitivo, ou seja, o não masculino - que aponta para o fixo. Nesse sentido, a escrita feminina não pode ser definida: definições implicam confinamento, codificação - ou seja, pressupõem a falocentricidade. Na fase pré-edípica, a diferença sexual ainda não se implantou no psiquismo. Nesse sentido, esse tipo de escrita não seria restrito às mulheres, anatomicamente falando - homens também poderiam ter acesso a ela. "Poetas resvalam, em alguma medida, na mulher" (CIXOUS in MARKS; DE COURTIVRON, 1975/1981, p. 249), ou seja, poetas teriam um acesso privilegiado ao inconsciente, instância onde a mulher sobrevive como reprimida. Daí todo o deslumbramento de 
Cixous por Joyce, que tanto pretendeu desmantelar a linguagem, suas regras; favorecer a musicalidade e uma nova poética.

Como a escrita é submetida a processos históricos e culturais, ela pode ser transformada, e não mais reduzida aos padrões masculinos. Tais transgressões femininas recairiam sobre a "surdez do ouvido do homem, que escuta na linguagem somente o que é falado no masculino" (CIXOUS in MARKS; DE COURTIVRON, 1975/1981, p. 251).

Segundo Cixous, "não existe a cisão, a divisão feita pelo homem comum entre a lógica do discurso oral e a lógica do texto, ligada, assim como ele, a uma antiquada relação — servil, de cálculo - à mestria". Seria através do corpo que a mulher daria suporte à logica do seu discurso: "ela fisicamente materializa o que está pensando; ela o significa no seu corpo [...] porque ela não nega [o caráter] intratável e passional que participa da fala" ${ }^{9}$. Na escrita da mulher prevaleceria a musicalidade que Cixous aproxima da voz da mãe. "Mesmo que a mistificação fálica tenha geralmente contaminado as boas relações, uma mulher nunca está distante de sua mãe [...]. Há sempre nela um mínimo do bom leite materno. Ela escreve em tinta branca" (CIXOUS in MARKS; DE COURTIVRON, 1975/1981, p. 251).

Ou seja, nessa ótica, falo = pai. E Cixous se restringe à vertente de imaginarização do falo na figura paterna, contra a qual a mulher deve se rebelar e retornar ao materno, pré-simbólico — período no qual as pulsões ainda estariam em estudo bruto, indomadas: "a economia das suas pulsões é prodigiosa [...] a libido dela irá produzir efeitos ainda mais radicais em prol de mudanças políticas e sociais do que somos capazes de pensar" (CIXOUS in MARKS; DE COURTIVRON, 1975/1981, p. 252). Enquanto a sexualidade masculina gira em torno do pênis, a "libido da mulher" não se centralizaria em uma parte específica do corpo a prevalecer sobre outras. Ou seja, trata-se de uma sexualidade cujo caráter libidinal não se inscreve a partir de limites predeterminados. E esse "estilo" deve ser transposto à (nova) linguagem.

Nesse sentido, contra o teatro falocêntrico que impõe a diferença sexual, a repartição hierarquizante homem-mulher, proclama-se dar voz à bissexualidade primordial:

\footnotetext{
9 "Você, Dora, você a indomável, o corpo poético, você é a verdadeira "mestra" do Significante" (CIXOUS, 1975/1981, p. 257).
} 
Bissexualidade: o posicionamento no self de cada um da presença que se manifesta variada e insistentemente de acordo com cada pessoa, homem ou mulher - de ambos os sexos, não exclusão nem da diferença nem de um dos dois sexos e, a partir desta "selfautorização", multiplicação dos efeitos de inscrição do desejo, por todas as partes do meu corpo e do corpo do outro. (CIXOUS in MARKS; DE COURTIVRON, 1975/1981, p. 254; trad. nossa)

As mulheres tenderiam a ser mais beneficiadas pela bissexualidade enquanto o homem insistiria em manter sua "gloriosa monossexualidade fálica", a ideologia falocrática. E por quê? "Por medo de se tornar uma mulher!". Seria por isso que toda ciência, em que prevalece a visão masculina, inclusive a psicanálise, "foi constituída para reprimir a feminilidade" (CIXOUS in MARKS; DE COURTIVRON, 1975/1981, p. 254).

Simbólico, falo, linguagem, libido: todos elementos cruciais para psicanálise a terem sido elaborados aos moldes do masculino e com fins de manter o poder na mão dos homens, o que necessariamente exige a submissão da mulher — termo que funciona como sua exclusão constitutiva . Mas não só, desejo e falta também. E a negativização da mulher enquanto sujeito, na trama edípica, promoveria a positivação do homem:

Mas não somos obrigadas a depositar nossas vidas nos bancos da falta deles, a considerar a constituição do sujeito nos termos de um drama mutiladoramente reencenado, a constantemente reinstalar a religião do pai [...] Não temos motivos femininos para mantermos laços de fidelidade ou obediência-submissão ao negativo. (CIXOUS in MARKS; DE COURTIVRON, 1975/1981, p. 255; trad. nossa)

Adiante, agora abertamente em confronto com a letra lacaniana:

Não li ‘A significação do falo'? E sobre a separação, e sobre aquela parte do eu que, para nascer, deve-se submeter a uma ablação - uma ablação, eles dizem, sempre a ser celebrada pelo seu desejo? [...] O que é o desejo originado a partir de uma falta? Um desejo bem escasso. (CIXOUS in MARKS; DE COURTIVRON, 1975/1981, p. 262 ; trad. nossa)

Cixous proclama que a mulher tem, sim, um desejo próprio, e não aquele fundado a partir da falta de uma parte do seu corpo, constituído pela sequência: falta de pênis - castração - inveja do pênis. O desejo feminino não nasceria da privação de uma parte do corpo (ou da vingança por não ter um pênis): "eu não quero um pênis a decorar meu corpo" (CIXOUS in MARKS; DE COURTIVRON, 1975/1981, p. 262). Por fim, 
aconselha a postura que a mulher deveria ter frente à psicanálise falicizante, já que aquela sempre foi

remetida pela força de um trapaça a um lugar preciso na cadeia formada em beneficio de um significante privilegiado. (Nós) como remendos de uma cadeia que conduz, senão ao Nome-do-Pai, então, em um novo giro, ao lugar da mãe-fálica. Cuidado, minha amiga, ao significante que te remeteria a autoridade de um significado (...). Quebre o ciclo: não permaneça dentro do encerramento psicanalítico. Dê uma olhada, depois rompa. (CIXOUS in MARKS; DE COURTIVRON, 1975/1981, p. 263; trad. nossa)

Cixous, se admirada por muitos, teve dois dos seus principais estandartes vistos como dúvida dentro do próprio feminismo, como procede Schiach, em dois momentos. O primeiro, pela associação direta entre simbólico e poder:

Podemos verificar então que o 'simbólico' nos leva ao cerne dos problemas tratados nesse livro [O riso da Medusa], mas isso também o faz o próximo termo da citação: 'poder'. Cixous, nesse ponto, equacionou o poder com o simbólico. Não tenho certeza de que essa seja uma equação que todos estariam prontos para aceitar. (SCHIACH in BRENNAN, 1997, p. 207)

O segundo, pela própria engrenagem comum entre o projeto da escrita feminina e mudanças sociais:

O projeto é extremamente pessoal e, às vezes, explicitamente autobiográfico. Ele faz sentido em referência à própria prática textual de Cixous em seus romances e contos. Ela não consegue, todavia, nem mesmo em nível polêmico, manter consistente a equação entre o que as mulheres devem fazer para mudar seu espaço político e cultural e as estratégias da escrita feminina. (SCHIACH in BRENNAN, 1997, p. 213)

Apresentados tais comentários, façamos agora uma breve explanação histórica. No período pós-maio de 68, os debates na França se inflamam no próprio interior do feminismo; diversas facções surgem, umas fortemente opostas às outras, em diversos pontos teóricos e a respeito das estratégias que deveriam ser acatadas como forma de promover transformações sociais. Se o movimento da escrita feminina acusado, por muitos, de essencialista em sua abordagem do feminino - ganha terreno, surge também em solo francês o "Movimento de liberação das mulheres", sustentado por Antoinette Fouque, Monique Wittig e Josiane Chanel. Opondo-se a uma suposta tática ontologizante da mulher, pretendia-se ir contra qualquer tentativa de formação identitária sexual. O grupo "Psicanálise e Política", fundado e dirigido por Fouque, 
figura central da profusão dos ideais dessa ala do feminismo francês, conquista espaço, promove locais de discussão onde as mulheres poderiam falar e ser escutadas, tanto com relação à sua vida política quanto à sua sexualidade. Prega-se a reparação e a valorização da relação mãe-filha, uma sexualidade entre-mulheres a ser explorada, algo além do falicismo para o feminino - metas a serem elaboradas no plano das ideias, a partir de uma reformulação do lacanismo e da desconstrução derrideana. Além das reivindicações de ordem social, esse grupo propõe "escrever, traduzir, interpretar a história da sexualidade das mulheres a partir de uma escrita marcada, ela própria, pelo selo da diferença sexual" (ROUDINESCO, 1994, p. 562). Em 1974, Fouque e seu grupo criam as Éditions des Femmes, com a pretensão de publicar obras elaboradas a partir de uma escrita sexuada. Tal grupo mantinha uma relação ambígua com a psicanálise: se, por um lado, valoriza a retomada lacaniana que se deu via instrumentos da linguagem, e se muitas dessas feministas são vinculadas a escolas, são psicanalistas ou psicanalisandas; por outro, contesta a implicação no plano social de alguns de seus pilares conceituais que contribuiriam para o cenário de desfavorecimento da mulher, assim como o funcionamento das próprias instituições psicanalíticas e elementos da técnica em jogo na prática clínica. De toda forma,

daí resulta uma multiplicidade de reuniões, conflitos, amores homossexuais e publicações de toda sorte. Nunca se copulou tanto com o vocabulário da feminilidade quanto durante esse período de 1970 a 1975, quando finalmente se legalizam as medidas igualitárias reclamadas pelo antigo feminismo. (ROUDINESCO, 1994, p. 562)

Como já apontado, é justamente nesse momento que ganham profusão Irigaray, Cixous, Montrelay, Wittig e Kristeva.

A construção dessa vertente do edifício feminista psicanalítico de retomada do estruturalismo, da incursão da sexualidade feminina, e toda discussão a respeito do papel da linguagem- e, claro a abundância de revistas literárias e grupos de mulheres — atingiram Lacan:

Durante essa época, Lacan é apanhado pelo ardor feminino [...]. No plano teórico, Lacan não renuncia a nenhum ponto de sua teoria anterior [a esse período dos anos 70]. Mas o tom de seu discurso é diferente. Ele entendeu a mensagem de Antoniette e, se não adota nenhuma de suas afirmações, mostra-se sensível à nova retórica da escrita feminina. (ROUDINESCO, 1994, p. 566) 


\subsection{Montrelay e o gozo da sombra}

Se o texto célebre de Cixous é passional e apelativo às mulheres para que peguem suas armas em forma de escrita e combatam a linguagem masculina opressora, o trabalho de Michèle Montrelay parece se verter, também com esse pano de fundo, à construção de uma explanação teórica mais refinada e aguda a sustentar o projeto da escrita feminina, além de questionar operadores da prática psicanalítica, assim como Irigaray.

Montrelay contribui com um ponto que ultrapassa a perspectiva lacaniana ao trazer a noção de sombra, referente ao feminino, para a discussão - sombra cujo nome deveria ser inscrito abrindo espaço ao gozo feminino.

Em 1974, Irigaray publica Speculm: de l'autre femme, fortemente marcado pelo M.L.F. (Mouvement de Libération des Femmes) e que causou grande alvoroço ao propor um plano de ação contra a linguagem opressora do homem. Um ano depois, Cixous e Clément publicam La jeune née, em que se opõe a escrita da mulher àquela formatada pelo falocentrismo. Em 1977, Montrelay, que "mantém com Lacan uma verdadeira relação de amor cortês" (ROUDINESCO, 1994, p. 562) publica L'ombre et le nom.

Nesse contexto, essa "figura magnífica da grande aventura lacaniana" (ROUDINESCO, 1994, p. 562) introduz a ele a obra Le ravissement de Lol V. Stein de Marguerite Duras, para seu encantamento ${ }^{10}$. Montrelay a tem como um emblema do feminismo literário, como o mais puro representante da escrita do corpo da mulher. Duras, além de ser escritora mulher, apresenta personagens que ganham destaque justamente por serem seres atormentados, viverem no ócio, horrorizados e capturados pelo nada - é com essa feminilidade remetida ao negativo imprevisível, explosivo e que leva a um êxtase mudo que os homens do romance se defrontam.

No romance, ao presenciar a longa cena da dança de seu noivo com outra mulher, Lol não reage nem sofre da forma prevista pelo senso comum. Ela permanece indiferente, enquanto presa em um arrebatamento que a despossui de seu corpo,

\footnotetext{
${ }^{10}$ Lacan produzirá um texto: “À Marguerite Duras, Lacan dedicou-lhe um escrito homenageando a escritora por ter logrado transmitir com a novela Le ravissement de Lol V. Stein "as taciturnas núpcias da vida vazia com o objeto indescritível", elucidando através do arrebatamento da personagem a função da letra na localização do gozo" (FUENTES, 2009, p. 211).
} 
trancafiando-a em uma fascinante experiência de gozo - este seria o lugar da sombra que Montrelay destaca no gozo feminino.

Se, com Beauvoir, tratava-se de uma mulher que buscava se libertar, exigia direitos, questionava a ordem cultural e o falicismo freudiano; com Duras, o feminino aponta para uma especificidade até então não descrita, ao flertar com o vazio - outra maneira de abordá-lo, a partir de suas idiossincracias, nonsense e desmesura. Com o mérito de não aludir ao campo do patológico,

Marguerite Duras não vai beber em nenhuma fonte freudiana ou psiquiátrica. Desconhece radicalmente os discursos 'clínicos' sobre a loucura, e é por essa razão, talvez, que os psicanalistas dos anos 70 ficam 'extasiados' com esse relato e com a estranha proximidade de um dizer que fala da loucura feita mulher sem a menor alusão a qualquer nosologia. (ROUDINESCO, 1994, p. 564)

Montrelay se pergunta qual seria a postura típica de um analista que tomasse a dispersa e anestesiada Lol como paciente. Invariavelmente, indagaria: "Ela é louca?". Não seria o caso de nos deixarmos levar por nosografias ou pretensões diagnósticas, mas sim pelo que ela ilumina da condição humana:

Se se considera Lol como um personagem distinto, o diagnóstico de loucura latente, virtual - depois, ao fim do romance, manifesta não pode ser colocado. Esse diagnóstico não leva muito longe [...]. Lol é essa parte de nós mesmos que se mantém do lado da coisa, que reside no gozo, na Sombra, sempre excluída, inumana, escondida em algum lugar como uma besta. Sem ela, o inconsciente não pode existir. (MONTRELAY, 1977, p. 23; trad. nossa)

Se a palavra pode ser entendida como um prolongamento do corpo, em vias de falar, tal como prega a escrita feminina, Montrelay se esforça para dar uma sustentação teórica séria a esse projeto e considera que tal mecanismo de funcionamento pode ser pensado ao lado da clínica dos sujeitos femininos e ainda promover o acesso a um universo que o simbólico não atingiria. Para além da hipótese de uma libido feminina - e mesmo de um inconsciente feminino - Montrelay questiona se a técnica psicanalítica não deveria levar em conta a particularidade do modus operandi da mulher. A relação transferencial é a mesma da que se estabelece com um homem? A interpretação exigiria distinção entre masculina e feminina? Mas o que, para além dos enunciados, deve ser escutado na fala feminina que revelaria com mais concisão suas especificidades? O ritmo. 
Após certo tempo, o psicanalista tem a chance de notar os grandes ritmos segundo os quais o discurso do paciente se desenrola. Montrelay (1977, p. 28) levanta a hipótese de que tais ritmos resultem da "condensação periódica da articulação significante", cuja materialidade resiste ao conhecimento e não é suscetível à intepretação clínica. É resíduo - e, ao mesmo tempo, germe — dos efeitos simbólicos. Tais grandes ritmos, segundo Montrelay (1977), estabeleceriam uma relação definitiva com o inconsciente na instalação da transferência analítica.

Estaríamos aqui em outra dimensão, não aquela do significante nem do significado: dimensão real, que se furtaria a qualquer classificação linguística e que apontaria para o feminino.

Esses ritmos se observam com uma nitidez particular na palavra dita "histérica", mas que deveria ser, sobretudo qualificada de feminina. [...]. Não somente o discurso feminino acusa os ritmos da transferência, mas ele implica que as trajetórias de atravessamento das zonas do campo do Outro, que elas mesmas não têm nada a ver com o que se nomeia comumente de 'discurso', ou seja, a articulação significante. (MONTRELAY, 1977, pp. 28-9; trad. nossa)

Atravessam-se essas "zonas de sombras", pontos cegos do simbólico, indo do campo de articulação ao "abismo do nonsense que se abre em todo discurso, o real do discurso" (MONTRELAY, 1977, p. 29).

Se a transferência existe, uma transformação é produzida no interior do enunciado (se não existe, passagem ao ato ou sintoma): "ele se torna real, ou seja, assume valor de coisa" (MONTRELAY, 1977, p. 32) - a coisa, segundo ela, existiria fora do inconsciente, cuja percepção é impossível. A coisa não pode ser revelada no discurso, mas pode ser produzida onde não podemos estar enquanto sujeitos, na Outra cena. "A coisa não está no inconsciente, mas isso não impede que ela exista e que produza seus efeitos: no reservatório de gozo que é o isso" (MONTRELAY, 1977, p. $33)$.

A partir de quais índices se constataria que, por trás da palavra, há o real? Por exemplo, quando uma palavra é tomada em bloco na sua materialidade, sob efeito de condensação,

Tudo se passa como se o significante não se representasse mais para outro significante, destituído de sua função por formar um enunciado absoluto, que simultaneamente diz tudo ou nada [...] vazio de sentido e pleno de materialidade [...], ele só é aparentemente simbólico; ele está lá, real. (MONTRELAY, 1977, p. 34; trad. nossa) 
Nesse caso, é como se só houvesse o corpo. É como se uma metamorfose se operasse na palavra, tornando-se uma presença real no próprio corpo. Num certo tipo de feminilidade, corpo e discurso se confundiriam; e, nesse "discurso real" (MONTRELAY, 1977, p. 35), o corpo faria as vezes do Outro.

A coisa, cujo caráter é disruptivo, permite a eflorescência do desejo, trazendo implicações clínicas. "Em outros termos, o enunciado enquanto coisa se insere na dialética do desejo, na medida em que, fracionado pelo desenrolar das sessões, ele não é mais que resíduo: a coisa toma valor de pequeno $a$, porque sua perda instaura um nonsense que é a condição do desejo" (MONTRELAY, 1977, p. 36). Novas rupturas são produzidas, novos cortes na cadeia. A coisa aparece aqui sob um "modo propriamente poético, ela criou um corte, uma articulação significante que anteriormente não existia" (MONTRELAY, 1977, p. 37).

O discurso analítico se desenrolaria como uma banda de Moebius. Uma face é a do enunciado, que, retorcida, acaba retornando ao ponto de origem. Após esse retorno, passa-se ao real e uma transformação é operada. Esses dois tours instauram uma clivagem, inaugural do inconsciente, e "o enunciado traça uma linha que separa a coisa do significante [...]. Essa linha pode ser identificada a uma escrita que não representa nada, mas torna a representação possível” (MONTRELAY, 1977, p. 38; grifo nosso). Se há transferência, isso pode ocorrer na análise; se é passível de ser posta em papel, isto pode fundar um novo tipo de escrita.

Porém, não se trataria de conceitos de mesmo alcance. A escrita iria além do que é possível se passar na transferência, dadas as restrições a que esta é submetida. $\mathrm{O}$ ato de escrever abriria as portas para um campo impossível à prática analítica. Se o analista convida à associação livre e ao desfiladeiro de significantes, procurando “desconstruir a língua, ou a consistência que se dá aos esquemas imaginários onde o sujeito se localiza", tal trabalho seria infindável, já que suas unidades tenderiam a se reagrupar novamente. Sob transferência, procura-se "mudar a economia e as trocas de um número restrito de significantes, que são sempre os mesmos". Para Montrelay, ao contrário, o trabalho que ela propõe não pretenderia tanto trazer à tona o que está recalcado, mas sim promover mudanças. Porém, “o recalcado primordial permanece na sombra" (MONTRELAY, 1977, p. 51).

Quando se escreve, há a possibilidade de as coisas se darem de outra forma: “[...] à força de deixar de se escrever por significantes, à força de lhes restituir seu gozo e seu corpo, ver esse corpo e esse gozo significados por eles, e entregar-se parcialmente 
aos seus nonsense e opacidades?" (MONTRELAY, 1977, p. 51). Um traço que surge a partir de Outra cena, signo que exclui o "eu" do pensamento, a ser sustentado somente por sua intensidade. Seria justamente no corpo, na insignificância no qual é abandonado, que "o gozo resiste a ser abarcado pela linguagem que pretenderia tomá-lo para si [...]. Atirado na sombra, feito transparente pelo "trabalho" literário, o corpo se torna potente em se fazer de tela a esse gozo, que invade toda a cena" (MONTRELAY, 1977, p. 52). Esse tipo de literatura permitiria a escrita da substância e da experiência gozosa do corpo impossível de ser articulada aos modos convencionais. Contudo, não se trataria de uma técnica mais eficaz de acessar o inconsciente e iluminar o que até então insistia em permanecer na obscuridade, mas de um suplemento.

Dizer que numa obra de arte se prolonga ou se projeta o inconsciente daquele que a faz é inexato. Esse inconsciente deve ser abolido até o momento no qual a obra surge e o suplementa. Ela se torna a cena pulsional verdadeira, onde o material deslocado pelo significante faz borda, ou seja, funciona como um orifício. É nesse sentido que um texto [...] se torna ele mesmo mais que um corpo "da realidade", corpo narcísico. (MONTRELAY, 1977, p. 52; trad. nossa)

Nessa escrita, deixa-se de se guiar por leis que comandam os ofícios da realidade e referências imaginárias. Não há restrições técnicas e entrega-se aos ritmos do corpo. A obra se cria à medida que o individuo é anulado: não se trata de expor a história pessoal do sujeito, de se deixar conduzir pelo seu desejo, mas pelo real. A obra pertence ao que está fora do escritor. Por mais que o traço mais arcaico se apoie no narcisismo primário do autor, ele não pode ser pensado, ele só escapa. Esse traço condensa gozo. Exemplo disso seria a estátua de Bernini, que "mostra um gozo no qual o inconsciente, tomando corpo, goza por fim de sua expropriação" (MONTRELAY, 1977, p. 54).

Os trabalhos publicados em Recherches psychanalytiques nouvelles sur la sexualité, de 1964, dirigido por Chasseguet-Smirgel, repercutem significativamente em Montrelay, que passa a discorrer sobre o particular da mulher também incidindo sobre outros elementos, como o inconsciente, a angústia, a pulsão e o prazer, que inevitavelmente transmitiriam seus efeitos à escrita feminina.

Naquele momento histórico, cabia ao feminismo psicanalítico decidir entre duas alternativas, sustentadas a partir de duas concepções contraditórias: freudianamente, defender que a libido tem essência masculina e seus correlatos teóricos 
— clitóris $=$ pênis, sendo a erogeneização da vagina e o adentrar na feminilidade um passo à frente —; ou, como pregava Jones, clamar pela existência de uma libido especificamente feminina. Ora, tal oposição não se confirmaria pela clínica, tal como aponta Montrelay - a vagina é erogeneizada desde muito cedo. Contudo, esse argumento "clínico" não deveria fazer com que aquele debate fosse esquecido. Seriam duas posições incompatíveis, sim, mas que coexistiriam no inconsciente feminino, falocentrismo $e$ concentricidade (MONTRELAY, 1977, p. 61; grifo nosso). Dever-se-ia reconhecer que essa polarização Freud-Jones é mais um jogo de escola, pois, no fundo, "aquela contradição se encontra como um jogo de forças estruturante do inconsciente feminino" (MONTRELAY, 1977, p. 62).

Classicamente, a angústia em psicanalise é a angustia de castração, comum a ambos os sexos. Haveria também um processo especificadamente feminino da angústia? A angústia é sem objeto, aparece em um "momento limite de bloqueio da representação consciente e inconsciente" (MONTRELAY, 1977, p. 62). Um exemplo do que seria a representação consciente diz respeito à castração imaginária expressa nas teorias sexuais infantis, que, num segundo momento, são banidas para o inconsciente. Desprende-se dos objetos da realidade e se apela para imagens, jogos de palavras, sonoridades e imagens articuláveis. "Por que então [não se pode considerar que] as palavras passem a ser os objetos de investimento? [...]. Neste sentido, a representação inconsciente, consequentemente, não é nada mais que um texto" (MONTRELAY, 1977, p. 64). Já que a sexualidade é tanto regida pela pulsão quanto pelo que é dito, o discurso teria uma repercussão direta no corpo e atuaria sobre o gozo. Na análise, o paciente fala de algo que até então não era pensável. Por exemplo, quando a dimensão castradora da castração está em falta, anulada, produz-se a angústia. E como Montrelay considera, a partir disso, uma técnica própria ao feminino?

No tratamento da mulher, o ponto não seria tornar a sexualidade mais consciente, "interpretar ao modo clássico". "[...] no quadro da cura, a feminilidade resiste surdamente à análise" (MONTRELAY, 1977, p. 66). Por quê? Porque como não é passível de representação, não é recalcável (só é recalcável o que já havia anteriormente sido passível de representação). "A sexualidade da mulher é suscetível de permanecer à margem do todo recalcamento" (MONTRELAY, 1977, p. 68). Então há de se introduzir uma representação da castração, "fazer passar" a sexualidade no discurso. Esse tipo de "interpretação permitiria reparar certa função cultural, social, da psicanálise" (MONTRELAY, 1977, p. 76), no caso, de ter recalcado a feminilidade. 
Essa interpretação particular se daria em benefício do feminino sempre deslocado e emudecido - o que não que dizer que tudo do feminino é passível de inscrição e que se teria como meta clínica o esvaziamento total da angústia.

Comparando os destinos do erotismo do homem e da mulher, Montrelay aponta que "o erotismo feminino é mais censurado [pela ordem social], ao passo que menos recalcado que o do homem" (MONTRELAY, 1977, p. 67). Se sua expressão no corpo social é mais bloqueada do que a do homem, no universo pulsional se dá o contrário. Há todo um campo do feminino que está fora ou não submetido ao recalque, já que irrepresentável, em estado selvagem. Neste sentido, as pulsões femininas se submeteriam às "leis pulsionais mais arcaicas" (MONTRELAY, 1977, p. 68). Por outro lado, também não é correto afirmar que essa precocidade clinicamente constatável da feminilidade faria obstáculo à maturação pulsional, o que manteria todo o erotismo feminino fora da representação da castração (MONTRELAY, 1977, p. 69). Também cabe ressaltar que estamos falando de feminilidade, não de mulher ou do sujeito feminino. Homens podem ter acesso à feminilidade, que Montrelay diz correlata às "pulsões femininas (orais, anais, vaginais), resistentes ao processo de recalque" (MONTRELAY, 1977, p. 67). Além disso, como já afirmamos "a feminilidade faz eco à interpretação na medida em que ignora o recalque" (MONTRELAY, 1977, p. 66). Outro modo de interpretar, então, quando se trata do feminino.

Para Montrelay, a relação da mulher com seu próprio corpo, relação narcísica e erótica, faria obstáculo ao processo do recalcamento. A mulher goza do seu corpo como se este se confundisse com o corpo do outro; cada evento de sua vida sexual (puberdade e maternidade, por exemplo) a toca como se tivesse vindo de outro, de fora, atualizando a relação com a mãe. Assim o real do seu corpo põe em jogo o real de outro corpo, contra o que a mulher não tem como se defender - essa relação com o corpo (materno) não pode ser perdida, porque também não está submetida à representação, dimensão real do corpo que se impõe e provoca angústia. Essa vertente seria o "continente negro" da mulher, que conviveria ao lado do falo - este, sim, representável.

Contra essa angústia, a mulher tenta lidar como pode: uma maneira é a construção da mascarada (tal como trata Lacan a partir de Rivière) — processo fálico, mas que só funcionaria como forma de dar conta de uma versão imaginária da castração: ser o que falta ao homem, adequar-se à fantasia dele (principalmente construída por uma organização masculina do olhar); ornar-se e enfeitar-se, mas em 
vão. Essa tentativa de fazer obstáculo à castração, por sua urgência, só escancara a dimensão da falta feminina. Mas como lidar com isso na análise? Como fazer o corpo entrar? Ou a escrita seria a única saída?

"O inconsciente feminino se modifica não tanto pela mudança de objeto de amor quanto pela mudança de representação inconsciente" (MONTRELAY, 1977, p. 73). Os primeiros representantes concêntricos, arcaicos, ligados à mãe, tendem a ser substituídos pelos representantes fálicos masculinos. Interessante que Montrelay aponta que, nessa operação, marcada pela entrada da lei e dos ideais do pai no discurso, "a mulher não é mutilada do pênis que jamais teve, mas privada das sensações da sexualidade primária. Ela a esquece, ou mesmo recalca a feminilidade, e tal esquecimento constitui a castração simbólica da mulher" (MONTRELAY, 1977, p. 74). A castração simbólica da mulher é correlata da privação de sua sexualidade primordial. Uma parte é passível de representação, entra no discurso, pode ser recalcada: não-toda. Essa faceta da sexualidade feminina não representável é a que encontra o texto como plataforma de gozo.

Seguindo essa linha de pensamento, Montrelay chega mesmo a elucubrar que possa haver dois tipos de prazer amoroso na mulher, o precoce e o sublime. $\mathrm{O}$ primeiro tem a ver com efeitos de experiências da sexualidade arcaica, quando, por exemplo, há dois indivíduos na cena amorosa e a mulher, "no auge do orgasmo [pode] experimentar o gozo que ela pode ter dela mesma" (MONTRELAY, 1977, p. 77) - o que também leva à angústia. $\mathrm{O}$ segundo tem a ver com a mulher no campo do Outro: se há um prazer atado ao significante, quando, por exemplo, ele é resgatado do que foi reprimido no dito espirituoso, a feminilidade envolveria outro tipo de prazer, sublime, sem significação possível.

[...] como no sonho ou na hipnose, como o ato poético, o prazer sublime marca um momento onde a representação inconsciente adquire valor absoluto: onde o ato de articular, dito de outro modo, promove o sentido do discurso. Sentido de nada. Dissipando toda significação, ele se apodera da mulher, capta-a na sua progressão e ritmo. (MONTRELAY, 1977, p. 79; trad. nossa)

Esse tipo de prazer, salvo algumas exceções, segundo Montrelay, não seria de fácil acesso ao homem — já que este estaria preso à mestria de gozar por fazer gozar — e, além do mais, devotado ao seu órgão no ato de amor — haja vista a tão frequente 
preocupação com o risco da detumescência associada à fantasia da demanda insaciável da mulher.

Frente à separação do Outro e a "abertura do inconsciente para todos os ventos" (MONTRELAY, 1977, p. 151), que soa como uma ameaça, o homem a oblitera se voltando a uma parte do corpo, o pênis, "órgão privilegiado dessa redução" (MONTRELAY, 1977, p. 151). É como se, para viver a vida das palavras, esse órgão precisasse ser destacado.

É por isso que a palavra dos homens — não o discurso inconsciente, mas o que ele diz ou escreve - difere da palavra da mulher. As palavras dos homens o separam dele. Elas o precedem. [...] Entre as palavras e ele, há o seu sexo. (MONTRELAY, 1977, p. 151; trad. nossa)

Para Montrelay, o pênis retira a criança de um narcisismo fragmentado e organiza sua instância de prazer, localizando-a nesse ponto preciso. Já na economia do sublime da mulher, o prazer explode - deflagração e revelação. "Há, portanto, continuidade entre a elevação do prazer e seu apogeu no orgasmo: um leva o significante ao máximo de sua incandescência; o outro marca o momento no qual o discurso, explodindo sob o efeito de sua própria força, vem a se estilhaçar, disjuntar. Ele não é mais nada" (MONTRELAY, 1977, p. 80).

Se o homem se conforma ao pouco de sentido do seu prazer, aquele da mulher aponta para um sentido infinito e que escapa para sempre. Os fenômenos de significação se apagam; uma outra escrita para a incandescência do gozo.

O orgasmo do discurso conduz a esse ponto onde o gozo feminino é
determinado como escrita. Nesse ponto onde ele deve aparecer que
esse gozo e o texto literário (que também se escreve como um
orgasmo produzido no interior do discurso) são o efeito da morte do
significante que é o mesmo. (MONTRELAY, 1977, pp. 80-1; trad.
nossa)

Por fim, nunca é demais falar que Montrelay considera que o gozo feminino também é acessível ao homem, haja vista que o Homem dos lobos, segundo ela, experienciava-o: "Está lá esse gozo — ou saber — do qual lobo é feito. Gozo desconhecido, selvagem, prestes a se desencadear do outro lado da janela. 'Gozo feminino', que é o da mãe, ao qual o do filho é fixado por amor ao pai" (MONTRELAY, 1977, p. 105). Na mesma toada, relata que o Homem dos lobos teria o “desejo de gozar de uma feminilidade anal” (MONTRELAY, 1977, p. 107), porém 
estaria impedido "pela voz do lobo, que silenciosamente interdita todo gozo feminino 'homossexual'. As fezes, ou "pênis anal", não podem mais ser erotizados. A substância feminina escapou completamente" (MONTRELAY, 1977, p. 114).

Sim, homens podem ter acesso ao feminino e ao seu gozo: "no ato sexual, o pênis mergulha no gozo 'feminino", aponta Montrelay (1977, p. 151), mas a relação e a postura que eles mantêm frente a tal experiência é diferente das da mulher. Por exemplo, o homem fala de sua feminilidade ao modo de articulá-la, abrir vias, separar espaços, mas, por fim, para se afastar dela. "Um homem escreve, trabalha as palavras, colocando incialmente em jogo seu pênis [...] ele articula a substância das palavras. [...] Escrevendo, o homem se separa do Outro com palavras, se separa com a substância feminina delas [...]" (MONTRELAY, 1977, p. 152).

Pelo contrário, Montrelay considera que "uma mulher não se separa das palavras. Elas vêm às mulheres sem portarem um segredo a ser evitado”. Não são como objetos dos quais nos aproximaríamos para manipulá-los, como tende a fazer o homem que escreve. As palavras atingem-nas diretamente, sem mediação, daí ter-se considerado durante muito tempo que uma mulher não poderia criar: "um texto literário só pode existir separado de seu autor?" (MONTRELAY, 1977, p. 152). Somente trabalhar a linguagem como um homem, fazendo semblante de estar separado delas, como em textos-documentários? Montrelay acredita que não, acredita que é possível se adentrar nas palavras, contando, narrando-as, vivendo-as em seu próprio ritmo, como na escrita feminina - vocalizada, cantada, inventada, sem nenhum cerceamento, que trate da angústia, do corpo e da paixão. "Encontramos nesses textos como que um elemento onde a sensação, os pensamentos se desdobram, se abrem, desabrocham, e que te precede, no entanto. Texto-gozo, em perpétua extensão" (MONTRELAY, 1977, p. 153). Na escrita feminina, tanto as palavras quanto o ser estão concernidos, inseparáveis. As mulheres, "se, como diz Hélène Cixous em La jeune née, põem em risco todo o seu ser numa angústia quando devem "tomar a palavra", é que elas sabem do espaço onde as palavras vão ressoar, frequentemente desnaturalizado e recusado" (MONTRELAY, 1977, p. 152).

Tais textos, sugere Montrelay, não deveriam ser lidos como atestação do enfrentamento mãe-filha denunciado na histeria, mas como uma forma de dar corpo à violência intrínseca ao feminino, abertura às portas do real, tal como em Duras: solidão, abandono, angústia, sofrimento do corpo e seu desfalecimento irrompidos. "Quando nos 
aproximamos da Coisa, a sombra do próximo se perfila, diz Lacan, sobre um espetáculo de um ossuário" (MONTRELAY, 1977, p. 157).

Tal relação da mulher com o nada — a Coisa que se dá a ver do lado da mulher —, tal relação sublime, o homem, dada sua limitação fálica, deve recalcar. O homem tem de se defender de sua feminilidade e da relação direta que a mulher tem com o gozo. "O homem fica aterrorizado pela ameaça que a feminilidade faz incidir sobre 'seu' recalque" (MONTRELAY, 1977, p. 72): reatualização do homem que teme a mulher diabólica que o habita.

Escrita múltipla, misturada, gozosa, que mescla objetos naturais com manufaturados e substâncias corporais: desconcertante. "Os corpos, as palavras, os objetos da realidade decompõem-se, explodem, cuja matéria transformada revive e forma um novo tipo de substância "feminina", sublimada de gozo" (MONTRELAY, 1977, p. 158). A feminilidade fundaria a "linguagem 'delas"” (MONTRELAY, 1977, p. 163).

\subsection{Kristeva e o semiótico indomável}

Júlia Kristeva (1941-) é filóloga búlgara-francesa, psicanalista, crítica literária, romancista e professora emérita da Universidade Paris 7. Seu trabalho, vasto, aliado ao pós-estruturalismo, percorre os campos da linguagem e da arte, tingidos pela análise cultural e política. Nosso maior interesse se concentra na interface que estabelece entre semiótica e psicanálise - neste sentido, destacam-se as obras já clássicas Séméiotiké: recherches pour une sémanalyse (1969), La révolution du langage poétique (1974), Polylogue (1977) e Pouvoirs de l'horreur (1980).

Lacan demonstra entusiasmo pela obra de Kristeva. Em 17 de maio de 1977, com a própria Kristeva na plateia de seu seminário, ele diz:

Então, por ser de grande importância, eu vou anunciar a vocês o lançamento pela Seuil de um texto chamado Polylogue, que é de Julia Kristeva. Eu gosto muito desse texto. É uma coleção de certo número de artigos. Não é menos valioso. Eu ainda gostaria de me informar, junto de Julia Kristeva, uma vez que ela fez esse esforço esta manhã, de se prestar a esse incômodo, sobre como ela concebe esse Polylogue. (LACAN, 1976-77, p. 73; trad. nossa).

Lacan parecia interessado nos desdobramentos que a tese da filóloga poderia ter para a psicanálise - chegando a propor uma mixagem entre polylogue e seu 
neologismo "linguisteria", dando em "polilinguisteria" (LACAN, 1976-77, p. 73) —; assim como em saber o que Kristeva pensava sobre a metalinguagem - no caso, sobre o fato de que não há metalinguagem. Ao contrário do que se passou com Irigaray, Cixous e Wittig, o lacanismo não foi tratado por Kristeva como um inimigo a ser combatido em seu suposto ranço patriarcal e heterossexista - Kristeva se dedicou a incorporar o funcionamento do período pré-edípico e do corpo pulsional na sua proposta de revolução na linguagem.

Um exemplo de um incidente histórico entre Kristeva e Lacan é o da viagem que fariam em grupo à China. Em 1974, ao lado de Roland Barthes, Jean Wahl e Marcelin Pleynet, os dois comporiam a delegação, organizada por Philippe Sollers, da revista Tel Quel, para visitar o território chinês. Lacan estaria animado em explorar o inconsciente dos chineses, já que, segundo Kristeva, seria uma instância não estruturada como uma linguagem, mas como uma escrita. Contudo, Lacan declinou do convite (CALVET, 2012, pp. 247-8).

A proposta lacaniana de retornar a Freud fazendo uso de recursos linguísticos era importante para Kristeva na sua elaboração do conceito de linguagem poética e em sua formulação do "sujeito-escritor", que não se confunde com a noção de autor, a se furtar das leis psíquicas e linguísticas que visam normatizá-lo. O texto seria uma prática artística que visaria promover revoluções políticas:

Se existe um "discurso" que não é meramente um depósito de esguios estratos linguísticos, um arquivo de estruturas, ou o testemunho de corpos subtraídos, e é, ao invés disso, o elemento essencial de uma prática que envolve a soma das relações inconscientes, subjetivas e sociais nos gestos de confrontação e apropriação, destruição e construção — violência produtiva, em suma - é a "literatura", ou mais especificamente, o texto. (KRISTEVA, 1974/1984, p. 16; trad. nossa)

Mas, se nutria uma boa relação com Lacan, Kristeva não era unanimamente aceita pelo movimento feminista. Apesar de também questionar o modelo patriarcal atado à ordem simbólica, ela não se propunha a sustentar um edifício teórico que se dedicasse explicitamente à luta política das mulheres, mas sim à uma experiência literária que desmantelasse essências identitárias - além do mais, boa parte das suas investigações em literatura e poesia se focava nas obras de artistas avant-garde homens. (WRIGHT, 2000, p. 8). 
Kristeva se baseia "numa visão da linguagem como sistema móvel e provisório de significação, com suas categorizações constantemente perturbadas pelo ressoar de impulsos corporais primordiais" (WRIGHT in BRENNAN, 1997, pp. 193-4) — impulsos esses característicos do período pré-edípico e que poderiam retornar em todos os sujeitos, independentemente do sexo, sendo a escrita um de seus terrenos de inscrição. Segundo Wright (BRENNAN, 1997, pp. 193-4), não se pode dizer que a teoria de Kristeva seja uma teoria feminista, mas que, sem dúvida, fez muito em prol do feminino.

As práticas de significação, o conjunto sócio-político e a constituição do sujeito falante são ordens que, na visão de Kristeva, andam juntas — textualidade e subjetividade são tratadas a partir dos termos 'semiótico', 'simbólico' e 'tético', tal como se lê em La révolution du langage poétique.

O termo "semiótico" deriva da semiologia de Saussure; em Kristeva, diz respeito a uma das modalidades que participam da relação entre o mundo psíquico e o universo da significação - nesse caso, da infiltração do universo pulsional no campo da significação. O período semiótico, para Kristeva, é regido por relações imaginárias estruturadas narcisicamente a partir das identificações especulares que atam mãe e filho, cujo funcionamento se dá fora da baliza fálica que determina a organização e a hierarquização da vida pulsional. As condições semióticas não são passiveis de representação e não são regidas por ideais de coerência, unidade ou estabilidade. Essa tendência desagregadora precisaria ser reprimida para que o sujeito se tornasse um ser falante e entrasse na cultura.

Se corresponde à dispersão pulsional, a um estado indiferenciado onde a pulsão não pode ser fixada em suas vertentes oral, anal ou escópica, o semiótico fornece o espaço - intitulado de khora - em que o sujeito se constituirá: receptáculo correspondente à indiferenciação dos corpos de mãe e filho e ao momento em que ainda não se adquiriram as mínimas unidades linguísticas, prevalecendo sensações, movimentos e vocalizações - energia regida pelo processo primário. O semiótico oferece o material a partir do qual o processo de representação terá andamento.

Em outro sentido, o semiótico é caracterizado pela circulação dos impulsos sexuais por todo o corpo antes da sexualidade ser ordenada sob a primazia do genital e do corpo ser uma entidade estabelecida como unidade - a distinção sujeito-objeto ainda não pode ser feita com clareza. "O semiótico precede todas unidades, estruturas de oposição binária e formas hierárquicas de organização" (GROSZ, 1989, p. 43). 
Já o simbólico é relacionado ao pai, a uma organização social que funciona de acordo com imperativos da autoridade paterna e que vigora a partir de repressões de elementos imaginários relativos ao semiótico e ao corpo materno.

O simbólico é o que poria fim à dispersão pulsional, ao passo que tético seria justamente o espaço de intermediação entre tal ordem e o semiótico, uma antecipação enquanto ocorre a infiltração de resíduos semióticos no simbólico. O tético corresponderia ao espaço ou momento em que o processo edípico e o estágio do espelho estão em andamento, em que pulsões passam a ser formatadas e certa organização subjetiva começa a se esboçar - relações imaginárias estando em negociação com o simbólico. O próximo passo é o sujeito se submeter às leis da linguagem e o falo ser alçado ao status de significante privilegiado, a alteridade do outro ser reconhecida, a falta-a-ser instalada, levando o sujeito a se tornar um ser social e falante — linguagem, identidade e sociabilidade são os termos em jogo quando se cai sob o simbólico. "O semiótico e a khora são explicitamente maternais e femininos, na visão de Kristeva, enquanto o simbólico é paterno [...] O simbólico é 'erigido' tendo por base a repressão do materno" (GROSZ, 1989, p. 49) - Kristeva se alia ao pensamento amplamente difundido de que o feminino deve ser reprimido, que a khora deve ser silenciada, para que o perigo seja evitado e a civilização avance.

Contudo, simbólico e semiótico não devem ser pensados numa relação binária logocêntrica em que um elimina o outro - ao mesmo tempo em que o sujeito é impelido a se enquadrar em sistemas de significação, carrega-se o potencial de subvertêlos, como no retorno dos impulsos polimórficos na forma de ritmo e entonação que acompanham toda representação.

O simbólico impõe uma estrutura linguística determinada e normativa - o nascimento do eu anda ao lado da submissão às regras sintáticas e gramaticais da língua, assim como a identidade social e sexual. Contudo, todo esse cenário é constantemente ameaçado pelo rompimento dos limites do tético e do semiótico, que podem levar a colapsos psicóticos, a perversões sexuais e ao rompimento da coerência e do sentido tal como se dá na poesia, descreve Grosz (1989, p. 48), irrompendo imprevisivelmente, como numa explosão de gozo incontrolável. A infiltração do semiótico tem consequências ao nível subjetivo, mas também social; atua nas relações pessoais e na produção discursiva. Toda a questão é como lidar com a interação entre esses dois domínios. 
A ruptura do simbólico pelo semiótico se evidencia nas obras literárias de vanguarda - daí Kristeva se voltar para uma região em que teoria linguística e literária se confunde com a psicanálise, para textos que sinalizem a instabilidade do sujeito e apontem para a deformidade do sentido, para a tensão contraditória que habita ambos; nos trabalhos experimentais de Mallarmé, Artaud, Lautréamont e Joyce, principalmente, evidencia-se esta crise de representação que se dá a partir da infiltração do gozo semiótico inarticulável.

Kristeva considera que a capacidade de choque dessas obras teria efeitos políticos, prescreveria representações não assimiláveis à ordem social, mas não com fins de alimentar ideologias - trata-se de desestabilizar as subjetividades e de romper com os enquadramentos identitários —; a arte seria uma forma de legitimação do semiótico, lhe dando certa expressão simbólica. Neste sentido, seria uma forma de introduzir o gozo excessivo e sem limites do semiótico, marcado pelo ritmo e pela musicalidade, em âmbito social via produção de textos; e, com sua força subversiva, de abalar a ordem das convenções. O ponto é questionar os limites da linguagem, pois, afinal de contas, para Kristeva, não é possível escrever textos, mesmo esses, sem recursos simbólicos — o que importa é problematizar a lei e resistir a ela através de transgressões. "Semanálise" é a doutrina em que Kristeva propõe a se dedicar ao estudo da deformação dos signos e dos processos do excesso da significação - daquilo que, como resto, resiste a ser incorporado.

Em Pouvoirs de l'horreur, dá tratamento especial a esse resto, que passa a ser denominado de abjeto; que, não especulálvel, confunde as fronteiras ente eu e outro; que desvirtua os limites da representação correspondentes ao campo do desejo e adentra no pântano do gozo. Experiências abjetas não podem ser incorporadas e também apontam para aquelas subjetividades impróprias que devem ser expulsas, como um dejeto; mas que, ao mesmo tempo, servem para a constituição do campo que se convencionou como próprio ou legítimo - campo esse cujos limites simbólicos são constantemente ameaçados pelo retorno imprevisível do abjeto, tanto em nível subjetivo quanto social. A noção de abjeto de Kristeva, tão celebrada por Butler, nos parece muito próxima da de objeto $a$ de Lacan:

Nesse sentido, só o gozo faz existir o abjeto como tal. Não o conhecemos, nem o desejamos, nós gozamos dele. Violentamente e com dor. Uma paixão. E como no gozo no qual o objeto $a$ do desejo detona o espelho abatido onde o eu aliena sua imagem para se minar 
no Outro, o abjeto não tem nada de objetivo nem mesmo de objetal. Ele é simplesmente uma fronteira, um dom repulsivo que o Outro, tornado alter ego, deixa cair para que o "eu" não desapareça nele, mas encontre, nessa alienação sublime, uma existência surrupiada. Um gozo, portanto, no qual o sujeito se fagocita, mas o Outro, em contrapartida, o impede de sucumbir a ele, tornando-o repugnante. (KRISTEVA, 1980, p. 17; trad. nossa)

Por fim, tratemos da relação ambígua que se passa entre Kristeva e o feminismo. Se por um lado, fica declarado o combate ao patriarcado via crítica ao simbólico, não fica claro que a filóloga estaria lutando pelas mulheres: não há uma declaração transparente de que as transgressões semióticas nem de que a linguagem poética seriam um veículo para as reivindicações feministas. Inclusive, Kristeva critica o movimento da escrita feminina por correr o risco de essencialização da identidade feminina, ao passo que a autora quer desestabilizar toda e qualquer identidade. Privilegia-se o pré-edípico, estado em que as posições masculina e feminina não foram definidas, em que homem e mulher ainda não são categorias codificadas — para certo feminismo, a meta de dissolver identidades seria um erro estratégico para o feminismo, tal como Braidotti (in BRENNAN, 1997) aponta, não havendo como operar transformações sociais sem partir de edificações identitárias.

E a respeito do papel da mulher no projeto de operar rupturas revolucionárias, Kristeva aponta: "Se a mulher tem um papel no andamento desse processo, é o de assumir uma função negativa: rejeitar tudo que seja finito, estruturas definidas, carregadas de sentido, no estado da sociedade. Tal atitude coloca a mulher do lado da explosão dos códigos sociais: com momentos revolucionários" (KRISTEVA, 1981, p. 166). Se Irigaray adota a posição de perseguir a especificidade da mulher através da suspensão do simbólico — para que, assim, a mulher possa se representar nos seus próprios termos - Kristeva tenderia a tratar dos meios de trazer à tona o que compete ao semiótico no que tem de desintegrador de quaisquer representações estáveis, tanto para homens quanto para mulheres. Irigaray perseguia a diferença entre um sexo e outro; Kristeva, a diferença interna a cada sujeito.

Contudo, essa suposta tendência desessencialista de Kristeva convive com a crítica de que a importância que foi concebida por ela à maternidade e ao corpo materno na experiência semiótica seria um retrocesso à biologização da mulher, um retorno à natureza. 
"Num sistema falogocêntrico onde o Nome do Pai oferece a metáfora operacional para a constituição do sujeito, a ideia de uma 'função simbólica feminina' equivale à reivindicação de uma função estruturante para a mãe" (BRAIDOTTI in BRENNAN, 1997, p. 133). Se Irigaray quer reaver a relação mãe-filha sem cair na maternidade como a única saída para a mulher, via curto-circuito simbólico, Kristeva encara a posição materna de uma outra forma. Em Des chinoises (apud GALLOP, 1982, p. 115), afirma: "uma mulher não tem nada do que rir quando a ordem simbólica entra em colapso. Ela pode desfrutar disso se, ao se identificar com a mãe, corpo com vagina, ela se imaginar ser o reprimido sublime que retorna nas fissuras daquela ordem". Uma identificação materna a resguardaria e a protegeria de se desestruturar frente à desestabilização da ordem simbólica. Importante frisar que a mãe que Kristeva valoriza é uma mãe defalicizada. Neste sentido, Kristeva não incita as mulheres - como o faz Cixous, por exemplo - a tomarem o poder da mão dos homens, mas a introduzirem uma quebra nas representações do poder levando para essa esfera o que a dimensão do seu corpo carrega de polimórfico, contraditório e multifacetado - afinal de contas, na leitura de Gallop (1982, p. 121), a mulher assumir o poder como o homem o faz não abalaria a estrutura que prescreve as próprias relações de poder, só alternaria a ocupação dos lugares de comando e submissão, mantendo as representações de homem e mulher intactas. Opinando sobre a direção do movimento feminista que se sustentaria no misticismo da mãe arcaica, abarcando o aforismo lacaniano, Kristeva afirma:

\footnotetext{
É nesse sentido que nós podemos entender as advertências contra a recente invasão da paranoia nos movimentos das mulheres, assim como a escandalosa sentença de Lacan "A mulher não existe". De fato, ela não existe com a letra maiúscula $\mathrm{A}$, possuidora de uma unidade mítica - um poder supremo, no qual se baseia o terror do poder e o terrorismo como o desejo de poder. Mas que força incrível para subversão no mundo moderno! E, ao mesmo tempo, que 'brincadeira arriscada'. (KRISTEVA, 1979/1986, p. 205; trad. nossa)
}

Outro ponto de mal-estar entre Kristeva e o feminismo mais voltado às práticas sociais é ela ter considerado que o processo de mudança não se daria sem a contraparte da mulher — não só mãe-filha, mas a díade pai-filha deve se pôr em movimento com fins de evitar paralisias opositivas: deve haver uma alternância permanente, não um sem o outro (KRISTEVA apud GALLOP, 1982, p. 121). 


\subsection{Wittig e o fim de homem e mulher}

"Nós devemos tornar brutalmente evidente que a psicanálise que veio depois de Freud, e particularmente Lacan, transformou seus conceitos em mitos - Diferença, Desejo, o Nomedo-Pai etc. Eles inclusive "sobremitificaram" os mitos, uma operação necessária a eles com fins de sistematicamente heterossexualizar a dimensão pessoal que repentinamente emergiu através dos indivíduos dominados dentro do campo histórico, particularmente através das mulheres, que deram início a sua luta quase dois séculos atrás."

— Monique Wittig (1992, p. 31; trad. nossa)

O nome de Monique Wittig (1935-2003) é fortemente associado ao M.L.F. (Mouvement de Libération des Femmes) e ao que se convencionou chamar de feminismo radical e feminismo lésbico. Seu trabalho se dá tanto na forma da teoria política, como se apresenta na coletânea de textos The straight mind (1992) quanto na da literatura de L'opoponax (1964). Adepta da teoria marxista e crítica ferrenha da psicanálise, ataca tanto sua teoria, a constituição do enquadre clínico, o funcionamento da instituição psicanalítica quanto o impacto de seu discurso na cultura. Butler e, mais recentemente, Preciado são, em muito, devedoras de suas ideias. Wittig considera que a luta das mulheres deve se sustentar em um ponto de vista diferente daquele sustentado incialmente pelo movimento feminista: no caso, retirando a mulher da cena — não se deve falar mais em opressão da mulher ou em direitos da mulher; em mulheres como iguais ou diferentes, por exemplo. Wittig propõe uma mudança de perspectiva, da mulher à lésbica, para que assim o movimento feminista seja teórica e politicamente alçado a outro patamar - "lésbicas não são mulheres", segundo Wittig (1992, p. 32), já que se encontram fora do regime político heterossexual do sistema patriarcal.

É notória a crítica de que o sistema patriarcal prescreve uma ideologia que determina que a classe das mulheres deva ser subordinada à dos homens. Contudo, Wittig considera que se ater somente à denúncia do patriarcalismo é uma estratégia precária na luta feminista. O que deve ser questionado é a própria edificação das categorias "homem" e "mulher". A existência de tais categorias, que só existem uma em relação à outra, deve-se ao sistema heterossexual. Para minar a heterossexualidade, entendida por Wittig como um regime político que se apoia na submissão das mulheres, 
aquelas categorias devem ser abolidas política, filosófica e simbolicamente, e nessa empreitada a comunidade lésbica deve ser estrategicamente acionada.

Importante salientar que não se trata de criar uma nova categoria, "lésbica", ou de que esta venha a substituir a de "mulher" - essa vertente de feminismo radical quer erradicar o regime político heterossexual, não simplesmente questioná-lo; e a estratégia seria a destruição das categorias de homem e mulher e outras correlatas, como as categorias de "gênero", "sexo" e "diferença sexual", que fazem parte do arcabouço conceitual criado pela "straight mind" que formatou a elaboração dos nossos conceitos, assim como a construção de nossas instituições e da cultura ocidental. A proposta de Wittig é a de que o humano seja abordado para além de toda categoria que envolva o sexual, rejeitando toda a ciência, inclusive a psicanálise, que se fundamenta nele ao tratar do sujeito.

“A ideologia da diferença sexual funciona como um censor na nossa cultura ao mascarar, sob alegação da natureza, as oposições sociais entre homem e mulher" (WITTIG, 1992, p. 2). Recorrer a termos como 'homem' e 'mulher' (diferença sexual, no sentido biológico) assim como a 'masculino' e 'feminino' (gênero) torna invisível que as diferenças sociais são produtos de ordem econômica, política e ideológica. A diferença sexual não é um dado bruto; ela só existe enquanto determinação social submetida, segundo Wittig, à mesma dialética presente na luta de classes. O pensamento dominante determina que, em todas as sociedades, há duas categorias de sexo com diferenças constitutivas, ontologicamente expressas em termos biológicos a serem refletidos em âmbito sociológico, legitimando, por exemplo, a divisão do trabalho. $\mathrm{O}$ sexo, tomado como o dado natural determinante, tenderia a tornar invisível o papel das relações sociais subjacentes. Neste sentido, "é a opressão que cria o sexo, e não o contrário" (WITTIG, 1992, p. 2) — não é o sexo que cria a opressão nem a causa da opressão é de ordem sexual. "A categoria de sexo não existe a priori, como anterior a toda sociedade" (WITTIG, 1992, p. 5). A categoria 'sexo' é um produto da sociedade heterossexual que se baseia no modelo da reprodução das espécies - modelo esse que legitimaria a apropriação da mulher pelo homem e que estaria na base do contrato de casamento, segundo Wittig. Também não se trata, para ela, de fundar uma sociedade que se sustente no matriarcado, já que a mudança, nesse caso, seria somente quanto ao sexo do opressor. Desse contexto, conclui a autora, a mulher não tem como escapar: a mulher não tem como ser pensada fora da categoria totalitária de sexo. 
Em certo sentido, se Wittig se aproxima de Beauvoir — não se nasce mulher e nenhum fato a determina, nem biológica, psicológica ou economicamente, sendo o feminino um produto criado pela civilização - , afasta-se dela, ao considerar que não seria o mito construído ao redor da mulher a causa da opressão, mas justamente a criação da categoria 'sexo' como um dado a priori. Esse sistema que cria as categorias 'homem' e 'mulher' acaba por possibilitar a proclamação de ideais — estes que acabam por causar sofrimento às mulheres que não correspondem a "mulheres de verdade". Wittig propõe dissociar "mulher" enquanto mito, formação imaginária, de "mulheres" enquanto classe - a luta política deve mirar essa última vertente, contra mulheres enquanto classes, produto da relação de espoliação. Leguil (2015, p. 33) aponta que, para Wittig, "não se nasce mulher, é certo, mas deve se fazer de tudo para que jamais se consinta em se tornar mulher" - tornar-se mulher se sustenta numa ideia do que seria uma mulher, alimentaria o mito da mulher: ser a mulher de um homem, ser mãe ou outras qualidades associadas ao feminino - mesmo aquelas que supostamente a deslocariam dos papéis que tradicionalmente lhes foram impostos. Para Wittig não importa: qualquer atributo concedido à mulher resultaria da estratégia de dominação masculina e estaria determinado pelo regime heterossexual. Se Beauvoir queria a liberação das mulheres do encarceramento dos mitos que o homem lhes impunha, Wittig quer impossibilitar toda e qualquer construção de mitos, toda e qualquer tentativa de elaboração de discursos sobre o feminino, ao fazer a própria categoria de mulher desaparecer - afinal de contas, "mulher" só existiria dentro do sistema de submissão ao homem. Então, para se voltar contra ao regime heterossexual, há de se recorrer a um elemento fora dele e de suas determinações conceituais. A lésbica está além da categoria de sexo. A lésbica não é um homem, não é uma mulher, não seria um produto da sociedade nem da natureza, segundo Wittig (1992, p. 13). A comunidade lésbica revelaria que a divisão entre homens e mulheres é política e ideologicamente construída enquanto entidades naturais. Para recusar a heterossexualidade, a lésbica não só rejeita o papel de mulher que a sociedade lhe dita, mas todo o poder político e ideológico prescrito pelo homem.

Wittig recorre ao marxismo ao pregar que o movimento feminista deveria levar cada mulher a ter a consciência de que os problemas que enfrenta são, de fato, problemas das mulheres enquanto classe - seus problemas privados são reflexos da política ditada pelo regime heterossexual que se fundamentaria numa doutrina da diferença sexual com fins de justificar a opressão sofrida. Os indivíduos têm sua 
dimensão particular, mas uma transformação social só ocorreria à medida que passassem a se reconhecer enquanto membros de uma classe oprimida.

Além desse objetivo, Wittig, seguindo a tradição do feminismo francês, também é atenta à importância política que a linguagem contempla; e acompanha os trabalhos de Lévi-Strauss e Lacan, desenvolvidos com base no estruturalismo. Para que o sistema ideológico seja analisado, Wittig considera que se deve recorrer da semiologia ao inconsciente. "A linguística engendra a semiologia e a linguística estrutural, a linguística estrutural engendra o estruturalismo, que engendra o Inconsciente Estrutural" (WITTIG, 1992, p. 22). Os diferentes discursos se interpenetram e se reforçam sempre produzindo um elemento a ser oprimido, mascarando a real causa da opressão — nesse processo, cria-se uma intuição de a-historicidade e de invariância da realidade social, como intocada pelos conflitos de classe. O psiquismo padeceria da mesma alienação, o que exigiria que especialistas como psicanalistas surjam com seus arsenais teóricos também invariantes - a fixidez dos conceitos seria fruto de uma estratégia de poder com fins de apagar as condições históricas subjacentes, o que, consequentemente, perpetuaria a situação de opressão tida como um dado natural. Essa é uma das principais críticas de Wittig à psicanálise:

A linguagem simbólica que funciona vantajosamente com poucos elementos, como dígitos (0-9), esses símbolos "inconscientemente produzidos" pelo psiquismo não são numerosos. Portanto, tais símbolos são facilmente impostos, através de terapia e teorização, sobre o inconsciente individual e coletivo. Somos ensinados que o Inconsciente, com extremo bom gosto, estrutura-se a partir de metáforas, por exemplo, o nome-do-pai, o complexo de Édipo, castração, assassinato-ou-morte-do-pai, troca de mulheres etc. Se o Inconsciente é fácil de ser controlado, não o é por qualquer um. [...]. Só especialistas efetuam a decifração do Inconsciente. (WITTIG, 1992, pp. 22-3; trad. nossa).

$\mathrm{Na}$ perspectiva wittigiana, o enquadre psicanalítico concederia ao condutor do tratamento, especialista-mestre, o poder de impor conteúdos ao paciente. Todo discurso teórico científico - no nosso caso, o psicanalítico — inclusive, deslegitimaria outros discursos ao considerá-los irrelevantes, ou mesmo ingênuos. Wittig salienta o quanto o discurso é uma das facetas que sustentam a opressão, e o discurso psicanalítico seria um deles. 
A "straight mind" tenderia a elevar os conceitos que produz, não só os do plano da consciência, ao status de leis gerais, a serem válidos para todas as épocas e todas sociedades:

Então se fala em troca de mulheres, diferença entre os sexos, ordem simbólica, Inconsciente, Desejo, Gozo, Cultura, promovendo um significado absoluto a esses conceitos, quando na verdade são apenas categorias fundadas a partir da heterossexualidade, que produz a diferença entre os sexos como um dogma político e filosófico. (WITTIG, 1992, pp. 27-8; trad. nossa)

Ou seja, a straight mind, com sua tendência universalizante, não consegue conceber uma cultura que funcione de outra forma que não a regida pelas relações ditadas pela heterossexualidade; submetidas a processos, teóricos e práticos, para os quais especialistas teriam os instrumentos adequados para estabelecer os limites do dentro e do fora do cenário social. Para Wittig, nesse sistema de pensamento, rejeitar a obrigação do coito e as instituições decorrentes dela como parte fundante da sociedade seria impossível, já que seria o mesmo que rejeitar a possibilidade da constituição do outro e da ordem simbólica. "Então, o lesbianismo, a homossexualidade e as sociedades que formamos não podem ser pensadas ou faladas, embora sempre tenham existido. A "straight mind" continua a afirmar que o incesto, e não a homossexualidade, representa sua principal interdição" (WITTIG, 1992, p. 28).

E tratando do inconsciente:

Se entre todas as produções da 'straight mind' eu especialmente questiono os modelos do Inconsciente Estrutural, é porque: no momento histórico em que a dominação de grupos sociais não pode mais aparecer como um necessidade lógica ao dominado, porque eles se revoltam, porque eles questionam as diferenças, Levi-Strauss, Lacan e seus epígonos recorrem a necessidades que escapam ao controle da consciência e, então, à responsabilidade dos indivíduos. (WITTIG, 1992, p. 30; trad. nossa)

Nessa leitura, prescrever processos, agora inconscientes (processos inconscientes sustentam a troca de mulheres, por exemplo), seria uma forma renovada de sustentar a dominação. "Não é de admirar, então, que só haja um Inconsciente, e que ele seja heterossexual. É um Inconsciente que, conscientemente, muito se dedica aos interesses dos mestres" (WITTIG, 1992, p. 31). Haveria uma mudança tática de termos — não se fala mais em dominação das mulheres, mas em diferença sexual, com o mesmo interesse político. 
Wittig considera que, assim como as instituições psicanalíticas operam a partir de um discurso tal que faz com que os psicanalistas que estejam fora delas se sintam oprimidos,

na experiência analítica há uma pessoa oprimida, o psicanalisante, cuja necessidade de comunicação é explorada e que (da mesma forma que cabia às bruxas, sob tortura, somente repetir a linguagem que o inquisidor queria ouvir) não tem outra escolha, (se ele/ela não pretende destruir o contrato implícito que lhe permite se comunicar e do qual ele/ela necessita), a não ser aceitar dizer o que se espera que ele/ela diga. Eles dizem que esse processo pode durar uma vida inteira - contrato cruel que constrange o ser humano a revelar sua miséria a um opressor que é diretamente responsável por ela, que o/a explora econômica, política, ideologicamente e cuja interpretação reduz essa miséria a algumas figuras de discurso. (WITTIG, 1992, p. 24; trad. nossa)

Para Wittig, essa necessidade do sujeito de se comunicar não deveria ter como único espaço de expressão o enquadre psicanalítico, que molda o discurso do paciente à escuta do analista que se orienta heterossexualmente. Há inúmeros testemunhos que

enfatizam a significância política da impossibilidade que lésbicas, feministas e homens gays encontram ao tentarem se comunicar em uma sociedade heterossexual, para além do trato com um psicanalista. Quando o estatuto das coisas é compreendido, (não se está doente ou necessita ser curado, mas tem-se um inimigo), o resultado é que a pessoa oprimida quebra o contrato psicanalítico. (WITTIG, 1992, p. 24; trad. nossa)

O contrato psicanalítico, na visão de Wittig, seria uma imposição, e a psicanálise, sustentada no regime heterossexual que alicerça a sociedade, ratificaria o discurso que oprime as lésbicas, as mulheres e os homossexuais. Para que sejam ouvidos, há de se moldar sua linguagem aos termos deles (assim como os psicanalistas devem moldar seu discurso ao que as instituições psicanalíticas esperam deles). "Nossa recusa de uma interpretação totalizante vinda da psicanálise faz com que os teóricos digam que nós negligenciamos a dimensão simbólica. Esses discursos nos impede toda possibilidade de criar nossas próprias categorias" (WITTIG, 1992, p. 25). Wittig também discorre sobre o simbólico e a suposta alegação dos psicanalistas de que se trataria de uma instância transcendental:

[...] eles objetam que há uma ordem simbólica, como se estivessem falando de uma dimensão que não tivesse nada a ver com dominação. 
Pobre de nós, a ordem simbólica participa da mesma realidade que a ordem política e econômica. Há um continuum entre suas realidades, um continuum no qual a abstração se impõe à materialidade e pode formatar o corpo assim como a mente daqueles que oprime. (WITTIG, 1992, p. 58; trad. nossa)

O simbólico, nessa perspectiva, precisa ter alguma relação com a realidade — se não fosse assim, não seria possível conceber transformações sociais a partir dele. A radical negativização ou evaziamento desse registro seria uma estratégia de poder com fins de manter a estagnação.

Para Wittig, a "straight mind", base da psicanálise, necessita operar por conceitos ontologizados, como a diferença sexual, o que é inevitavelmente marcado por relações de poder essencialmente normativas - o outro, o diferente; no caso: as mulheres, mas também os negros e os escravos devem ser encarados como elementos substancializados a serem subjugados pelo homem branco dominante, tomado como 'não diferente'. Mas, segundo Wittig, "o conceito de diferença não tem nada de ontológico. Ele é somente a forma com que o mestre interpreta uma situação histórica de dominação. A função da diferença é esconder todos os níveis dos conflitos de interesse, incluindo os ideológicos" (WITTIG, 1992, p. 29). Níveis a serem escondidos também com a invenção dos conceitos em psicanálise. Por fim, para Wittig, Lacan só viu o que quis ver: "Para Lacan, por exemplo, o que ele chama de 'discurso psicanalítico', ou de 'experiência analítica', ambos o ensinam o que ele já sabia [...] Na minha opinião, não há dúvida de que Lacan encontrou no Inconsciente estruturas que ele falou que encontrou, visto que ele previamente as pôs lá” (WITTIG, 1992, p. 23).

Wittig (1992, p. 49) pontua que os primeiros filósofos gregos eram monistas: o ser era Um. Foi com a escola de Pitágoras que se passou a conceber uma divisão no contexto do ser. O que permite a Aristóteles operar com dualidades e criar sua tábua de oposições metafísicas - constrói-se a série limitado-um-direito-homemluz-bom, por um lado, e ilimitado-vários-esquerdo-mulher-escuro-mau, por outro. Séries heterogêneas que fazem com que seus conceitos, da ordem prática à abstrata, sejam diferenciados, comparados e classificados. Tais termos, enquanto dimensões metafísicas, foram retirados dos seus contextos originais, o que faz com que o sentido de termos técnicos como 'Um', por exemplo, seja modificado - agora tudo o que é bom pertence à série do 'Um'. E, consequentemente, os elementos opostos passam a ser associados entre si — "mulher" é acrescida de sentido ao se ligar a mau e escuro. A dialética opera, segundo Wittig (1992, p. 51), confrontando duas séries de conotação 
metafísica, ser e não ser. "Cada filósofo da idade moderna, incluindo os linguistas, os psicanalistas, os antropólogos, nos dirão que sem tais categorias precisas de oposição (de diferença), não se pode raciocinar ou pensar, ou melhor, que fora delas significados não podem ser estabelecidos [...]" (WITTIG, 1992, p. 52). Cria-se um jogo de forças entre os lados, o do Um-universal, mestre-homem, e do Outro, escravo-mulher. Questionar a dialética faz Wittig (1992, p. 53) pensar no tipo de transformação que poderia ocorrer se as categorias que se posicionam do lado do Um, ou do ser, passassem a ocupar o do outro. Mas Wittig sempre considera que a estratégia adequada não é a substituição - as categorias Um-homem e Outro-mulher é que devem ser descartadas (WITTIG, 1992, p. 55).

Estamos então num tipo de feminismo para além do feminismo das diferenças - mulheres devem ser reconhecidas em suas especificidades e diferenças (biológicas, inclusive, para algumas de suas teóricas) com relação aos homens -, e do que prega a desessencialização de homem e mulher - sexo e gênero como entidades sem substância. Segundo Wittig (1992, p. 60), só há um gênero, o feminino; homem não teria gênero porque sua figura é associada ao universal, ao geral, ao sujeito do discurso — incitar se falar em gênero traz à baila o feminino, o que deve ser impedido. 'Gênero', segundo Wittig, necessariamente apresenta caráter de substância — seria um "conceito ontológico que reforça na linguagem a divisão entre os sexos" (WITTIG, 1992, p. 76). Daí o feminismo radical de Wittig querer erradicar a categoria de 'gênero'.

Se, segundo, Wittig (1992, p. 77), gênero não é um conceito que foi historicamente questionado dentro da filosofia, é porque era um conceito considerado autoevidente - como se, por pertencer à natureza das coisas ou à ordem social, não fizesse sentido discorrer sobre ele. Daí Wittig louvar todo esforço feito pelas feministas norte-americanas em insistir na concepção de gênero enquanto categoria sociológica construída artificialmente, sem essência natural. O próximo passo foi fazer justamente com que o gênero prevalecesse sobre o sexo, encarado como índice linguístico que carrega a oposição entre os sexos que leva à submissão das mulheres. Contudo, Wittig considera que a estratégia é falha: "da mesma forma que o sexo, homem e mulher, gênero, como conceito, é um instrumento no discurso político do contrato social enquanto heterossexual" (WITTIG, 1992, p. 77). Deslocar o debate de sexo para gênero não resolve o problema: "gênero é a sanção do sexo na linguagem, funcionando da mesma forma que a declaração do sexo no status civil" (WITTIG, 1992, p. 79). Fortalecer a discussão em torno desse termo tem o efeito reverso de manter a mulher no 
registro do particular ou no da minoria dominada, e homem no status de universal: "o gênero é muito prejudicial às mulheres no exercício da linguagem" (WITTIG, 1992, p. 80); deve-se examinar como o gênero aparece na linguagem e como opera nela — daí Wittig ter se dedicado tanto ao estudo do uso dos pronomes como do pronome elles em Les guérillères (WITTIG, 1971).

A linguagem, para Wittig (1992, p. 80), carrega o potencial de fazer com que todos tenham acesso ao estatuto de sujeito e parte da ideia de que "as mulheres são marcadas na linguagem pelo gênero" (WITTIG, 1992, p. 82). Tratar desse assunto a partir do gênero funcionaria justamente como um impeditivo, extirpando a subjetividade do ser humano não homem, privando as mulheres de autoridade discursiva. Só há um ser, um Um, para Wittig (1992, p. 80) — tratar do ser como dividido na linguagem através do gênero seria uma armadilha ontológica, pretendendo introduzir um ser que não existe —, o que faria com que a parte mulher fosse submetida a um grau menor. Daí a proposta de Wittig de que gênero seja uma categoria a ser anulada e retirada da linguagem. A nosso ver, há aqui grande proximidade com o que pensamos ser o sujeito em psicanálise - sexuado, sempre, já que inserido na linguagem, e, como tal, falicizado, mas que não leva o fator gênero na sua constituição. "Destruir as categorias de sexo na política e na filosofia, destruir gênero na linguagem (pelo menos para modificar seu uso) é parte do meu trabalho de escrita, como uma escritora" (WITTIG, 1992, p. 81) - por sinal, a grafia “ $a$ writer" não tem gênero. Se Butler e Irigaray sugerem nos servirmos dos gêneros, parodiá-los, para que com a repetição algo subversivo venha a tona, desestabilizando as normas e o caráter substancial das identidades, a solução prevista por Wittig é a extinção do gênero — proposta essa que, por sinal, influenciou largamente trabalhos atuais como os de Beatriz Preciado.

Nesse sentido, se Wittig também é associada ao movimento da escrita feminina, ela é terminantemente contra a forma com que esse movimento foi denominado - "feminino" se liga à "mulher", termo esse a ser suprimido, já que faz alusão a formações imaginárias que comporiam o mito referente à mulher. Wittig defende que uma escrita cujo tema fosse mulher ou homossexualidade, por exemplo, faz com que grande parte do público atingido seja de pessoas que enfrentam a mesma situação das mulheres ou dos homossexuais - ou seja, continuaria sendo uma minoria que se identifica com o assunto —, além de ser encarada como mais uma obra literária dentre outras. Wittig quer retirar tal problemática do âmbito do particular para colocá-la também como um tema universal, uma realidade literária como forma de abalar a 
realidade social. Nesse sentido, uma escrita, para promover transformações sociais que visem ao reposicionamento da mulher ou lésbica na sociedade, não deve se focar nos conteúdos, mas na forma - a transgressão se daria a partir de fragmentações gramaticais, minando as regras que vigoram na linguagem, o posicionamento e a formação das palavras. Falar ou escrever recorrendo a 'homem' e 'mulher' só mantém a heterossexualidade em vigência. Claro, os sistemas de signos que usam figuras de discurso devem ser politicamente analisados, mas a grande tática é agir na materialidade da linguagem tida como elemento que participa da ilusão que mantém a suposta fixidez histórica do campo político e das relações sociais.

A escrita experimental que Wittig sustenta seria transformadora ao não se dedicar à formação sentidos. Wittig considera que, para examinar a linguagem enquanto exercício direto de poder, devemos nos voltar para suas estruturas que determinam a construção das ideologias, e não ao exame da história ou da ideologia em si — para tanto, deve-se focar a matéria-prima que constitui a linguagem, para transgredi-la e desestabilizar o leitor.

Clotilde Leguil (2015), analisando a tese wittiguiana, considera que a meta de erradicação do elemento 'gênero' só se faz necessário ao se partir do pressuposto de que se trata de um elemento rígido, fruto de uma norma inescapável prescrita pelo regime heterossexual. Mas se gênero for entendido de outra forma, tal recurso seria dispensável. Nesse sentido, Leguil propõe tratar de gênero ao lado do ser sexuado em psicanálise, que, ao contrário do ser ontologizado, é inacabado e sempre aberto. Para ela, gênero pode ser pensado não só em sua vertente política ou de luta ideológica, não só como problemática coletiva ou de classe atrelada a uma imposição social, como propõe Wittig; ou como uma paródia, na letra butleriana — gênero é "um ponto opaco da existência" (LEGUIL, 2015, p. 11). Uma interrogação que todos temos e com relação à qual cada um se posiciona, sempre inconclusivamente, de uma forma singular. Denunciar os estereótipos de gênero é um trabalho necessário, mas Leguil considera que outro olhar também deve ser levado em conta. Nenhum sujeito se sente totalmente cômodo com seu gênero - nesse sentido, homens, mulheres, hétero, homossexuais, transexuais padecem da mesma angústia e conflito frente a um mistério comum: não se sabe o que homens e mulheres são, já que se trata de significantes. Assim, uma faceta do sofrimento decorrente do gênero não se restringe aos sujeitos que não se enquadram na norma, mas a todos os sujeitos, se entendermos gênero como um efeito inconsciente que impossibilita a todo e qualquer sujeito adequar-se às normas sociais. 
Ainda segundo Leguil, cada um reage de uma forma distinta às imposições normativas, de acordo com a sua história e seu percurso subjetivo. Gênero não se confunde nem com natureza nem com construção social, pertencendo ao campo do desejo inconsciente, do gozo e do corpo. Gênero também pode ser interpretado como uma resposta que o sujeito inventa frente à questão "que queres?", creditada ao Outro - nesse caso, gênero pode ser uma construção da fantasia própria de cada um. E mais radicalmente, "tornar-se um sujeito é chegar a assumir de uma maneira singular seu ser sexuado" (LEGUIL, 2015, p. 18) — assumir um gênero faria parte do processo da constituição subjetiva.

Leguil conclui que, se os estudos de gênero se voltam à relação conflituosa do sujeito frente às normas sociais que constrangem sua vida sexual, a psicanálise se dedica ao que faz do sexo e do gênero enigmas para o sujeito - enigma esse que não tem como ser devidamente tratado somente pela vertente política. Enigma fruto da faltaa-ser que marca o ser falante e faz da exibição, na tentativa de adequação a estereótipos, mascarada ou parada sexual, uma comédia dos gêneros. O sujeito da psicanálise seria justamente o que contesta a universalidade da norma.

Podemos pensar que o "livrar-se dos mitos", na obra de Wittig, é equivalente a querer livrar-se dos significados atribuídos à mulher. Para Lacan, tais significados não encontram o significante mulher - "A mulher não existe" é o aforismo lacaniano — , "o que conduz cada uma a se confrontar com um lacuna, dessa que consequentemente pode engendrar uma questão ao nível do ser: "sou eu uma mulher?" (LEGUIL, 2015, pp. 40-1). Leguil então enxerga três pontos em Lacan para se pensar gênero: trata-se de um modo de ser (sexuado), e não norma social; homem e mulher são tomados em sua incomensurabilidade (não há relação sexual); a mulher não como um somatório de atributos - A mulher não existe. Mas, ao contrário de Wittig, a não existência d'A mulher, na lógica lacaniana, não implicaria seu aniquilamento. 


\section{GÊNERO E LACAN}

Neste capítulo trataremos, inicialmente, de Robert Stoller. Seus desenvolvimentos teóricos a respeito do núcleo da identidade de gênero, pensamos, foram o contraponto lacaniano para a elaboração da noção de 'semblante sexual' do Seminário XVIII. Se tal noção permite considerar que, através do semblante-homem e do semblante-mulher, certa modalidade da relação sexual seria possível, Lacan defende explicitamente, logo em seguida nesse seminário, que a relação sexual não existe esta, sim, uma tese que persiste. Se, por um lado, participou da importação do termo gender para o campo de pesquisa sobre a sexualidade, a ser adotado posteriormente pelos gender studuies, Stoller foi alvo de muitas críticas, seja quanto ao diagnóstico que atribuiu à transexualidade, seja quanto ao binarismo no qual operava e o caráter substancializado no qual concebia a identidade sexual. Na sequência, discorreremos sobre o trabalho de Gayle Rubin, que, além de lançar o sistema sexo/gênero, contribui para engendrar a lente pela qual Lacan foi lido em solo norte-americano, deixando profundas marcas em Judith Butler — que, por sinal, também se voltou para Lacan no desenvolvimento da sua concepção de gênero. As críticas apuradas dessa filósofa obrigaram a psicanálise a rever alguns de seus fundamentos imprecisos e pontos cegos de sua teoria, como as noções de 'simbólico', 'diferença sexual' e as deliberações edípicas heterossexuais. Por fim, as polêmicas ideias de Beatriz Preciado sobre o dildo também nos obrigam a repensar o estatuto do falo em Lacan, o que nos permitirá o anúncio do seu tratamento enquanto função dentro da lógica na sexuação lacaniana.

\subsection{Stoller e o semblante lacaniano}

Robert Jesse Stoller (1924-1991) foi um psicanalista e psiquiatra norteamericano de grande impacto, cujas teses ressoam até hoje muito além de seu país. Atuou como professor de psiquiatria da Universidade da Califórnia de Los Angeles (UCLA), fundou a Gender Identity Research Clinic-UCLA e também era filiado à Los Angeles Psychoanalytic Society. Stoller dedicou sua pesquisa notadamente à problemática do gênero sexual e aos quadros clínicos tidos por ele como distúrbios de gênero, como a transexualidade, indo até às perversões sexuais, à dinâmica da excitação sexual e à pornografia. Além da clínica e da pesquisa, voltava-se também a estudos 
antropológicos, visando investigar como se dava a constituição das identidades sexuais e a expressão dos diferentes papéis de gênero em outras culturas.

Stoller dialogava tanto com o meio médico como com o psicanalítico, preferencialmente a escola kleiniana e a psicologia do ego, na qual Hartmann era um interlocutor privilegiado. É vasta a quantidade de trabalhos em medicina aos quais se refere, principalmente os de John Money, com quem Stoller trabalhou muito de perto na Johns Hopkins University em Baltimore. Nesse universo, no qual as pesquisas científicas são marcadas por métodos quantitativos, baseadas em evidências e regidas pelo positivismo, Stoller teve a coragem de estudar o que considerava "patologias do gênero sexual" adotando referenciais psicanalíticos como parte do seu método de pesquisa e da análise de resultados. Sua teoria sobre a transexualidade, inovadora e muito contestada, serviu como ponto de partida para a construção do pensamento de importantes autores da psicanálise lacaniana que trataram desse quadro, dentre os quais Catherine Millot, Moustapha Safouan, Henry Frignet e Marcel Czermak. Além do mais, foram justamente Money e Stoller que trouxeram o termo "gênero" para dentro dos estudos sobre a sexualidade, sendo absorvido pelas ciências sociais norte-americanas nos anos 70 .

A renovada e polêmica teoria que Stoller desenvolveu sobre identidade de gênero também marcou as pesquisas de autores da psicanálise como Omo Ralph Greenson $^{11}$, Margareth Mahler, Richar Green, J. Chasseguet Smirgel e Emilce Bleichmar. Além disso, foi alvo da crítica de teóricas dos estudos de gênero do porte de Butler e, no meio psicanalítico, do próprio Lacan, como veremos à frente.

Toda dedicação a casos que intitula como 'distúrbios de gênero' tem, no fundo - e isso Stoller confessa em vários momentos —, como motivo principal descobrir o desenvolvimento da masculinidade e da feminilidade em geral - a anormalidade esclareceria a normalidade, em seus termos. Stoller desconfiava, assim como Money, da unanimidade das raízes biológicas da identidade de gênero, indo, nesse sentido, contra a vigorosa corrente organicista da psiquiatria da época.

Apesar de Freud já em muitos textos ter se dedicado ao tema da identidade sexual e suas condições de constituição, Stoller foi o primeiro a abordar esse assunto em psicanálise recorrendo ao termo "gênero", em 1968. Para Stoller, faltava ao freudismo

\footnotetext{
${ }^{11}$ Stoller cita tal pesquisador em Sex and gender (1968). A tese de "desidentificação da mãe", defendida por Greenson como processo necessário ao direcionamento do filho à masculinidade, é especialmente cara a Stoller.
} 
clássico uma categoria que permitisse diferenciar radicalmente o sexo, como determinação orgânica do homem e da mulher, do sentimento social de identidade, o "sexo social" masculino ou feminino, a ser contemplado por "gênero" (ROUDINESCO; PLON, 1998, pp. 291-2). Cabe esclarecermos: sexo, nos termos de Stoller, refere-se a estados biológicos: genética, caracteres primários e secundários do sexo, aparato anatomofisiológico, endócrino e cerebral; gênero diz respeito a um conjunto de fenômenos como sentimentos, pensamentos, comportamentos e fantasias relacionados à masculinidade e à feminilidade, e não apresentam nenhuma ancoragem biológica — é determinado culturalmente, adquirido na vida pós-natal. Sexo e gênero não andam necessariamente lado a lado e um pode se desenvolver a despeito do outro.

Stoller também é conhecido pela releitura e pelas inversões que propôs à teoria freudiana. Enquanto Freud privilegiava o investimento sexual primário como determinante para a posição sexual primária (investimento heterossexual do menino e homossexual da menina, ambos tomando a mãe como primeiro objeto sexual), Stoller valorizava a posição identificatória inicial, ambos tomando a mãe como primeiro objeto de identificação (FERRAZ, 2001, p. 123). Seria o menino, e não a menina, que teria de enfrentar o caminho mais tortuoso com vias de consolidar sua identidade como homem - ao contrário de Freud, para quem a menina padeceria mais. Para Stoller, a feminilidade, e não a masculinidade, é primária. O complexo de Édipo não seria o único — ou, talvez, nem mesmo o mais importante - processo pelo qual se daria a construção da identidade sexual.

Fazia parte do seu método de investigação a observação naturalista, a avaliação e o tratamento psicológico de pessoas com distúrbios de gênero, assim como o acompanhamento de suas famílias durante anos — inclusive, Stoller acreditava que distúrbios de gênero poderiam ser evitados se detectados precocemente, no caso de crianças que apresentassem seus traços rudimentares. Para entender as origens da masculinidade e da feminilidade, Stoller pregava que se deveria recorrer à teoria psicanalítica, às teorias de aprendizagem e à biologia - cada uma dessas áreas, se tomadas isoladamente, levaria a explicações equivocadas. Inicialmente, nos anos 50, ele parte do estudo dos casos de intersexo; depois se dedica a transexuais e sujeitos perversos, notadamente nas décadas de 60 e 70; e, por fim, ao estudo da pornografia.

De partida, Stoller estava focado em quadros clínicos nos quais questões biológicas influenciavam os comportamentos de gênero e a aparência anatômica do sexo. Segundo Stoller (1968/1984, cap. 7, p. 3), Freud nunca teria abandonado a ideia 
de que, em muitos casos, forças biológicas influem na determinação da masculinidade e da feminilidade, a despeito das expectativas sociais e do papel da nomeação. Seria o fator biológico que preponderaria nos casos de sujeitos intersexo e portadores de síndromes genéticas, como as de Klinefelter e Turner. Como fruto de 10 anos de estudo e trabalho dedicados a 85 pacientes que apresentavam distúrbios de gênero e 63 membros de suas famílias, Stoller publica em 1968 a obra Sex and gender. Nela, aborda temas referentes ao desenvolvimento, à manutenção e à manifestação da masculinidade e da feminilidade; a certas síndromes genéticas e ao tratamento de distúrbios de gênero — além de defender teoricamente a relevância do período pré-edípico. Apesar da "força biológica" em jogo, Stoller estava particularmente atento à hipótese — já levantada por Money e os Hampson, ainda nos anos 50 - de que o comportamento genérico é preponderantemente marcado pela designação do sexo do sujeito e outros fatores ambientais.

Tal tese provém das constatações oriundas do estudo clássico desses dois pesquisadores: duas crianças apresentavam determinada síndrome genética que interferia nos andrógenos. Ambas eram genética e endocrinologicamente mulheres e apresentam estrutura interna também típica do sexo feminino, contudo a genitália externa era masculinizada. Ao nascimento, uma delas foi designada como menina e a outra, como menino. Por volta dos cinco anos, a primeira acreditou ser uma menina: dizia sentir-se como tal e não levantava questões sobre isso. Da mesma forma a segunda, com relação a ser um menino. Concluíram daí que o que determinou o gênero não foi o sexo biológico, mas experiências pós-natais, um complexo processo pelo qual a sociedade rotula um ser como homem ou mulher (STOLLER, 1968/1984, p. 5). Apesar de tal evidência, Stoller discute se, em todos os casos, a atribuição do sexo é um fator a predominar sobre outros na determinação da identidade de gênero.

Ao contrário daqueles pesquisadores, Stoller sustenta que forças biológicas não só interferem como são, em alguns casos, determinantes para a constituição dessa formação identitária. Essa hipótese surgiu a partir do trabalho com uma paciente que tinha aparência anatômica feminina normal ao nascimento e foi criada como uma menina pelos pais, mas que expressava já na infância tantos comportamentos masculinos que chegou ao ponto de ser diagnosticada como portadora de distúrbio de identidade de gênero. Na puberdade, seu corpo se virilizou e passou a viver como um homem. Submetida a testes, constatou-se que a paciente apresentava um déficit na produção de determinada enzima responsável pela metabolização de testosterona — daí 
Stoller ter concluído que não é possível afirmar que o gênero designado e sob o qual a criança foi tratada prevalece sempre sobre os fatores anatomofisiológicos ou forças biológicas.

Como forma de ilustração, passemos ao relato de um desses casos atendidos por Stoller (1968/1984):

A criança foi anatomicamente reconhecida e designada como menina ao nascimento. Contudo, comia muito rapidamente, como um glutão; só brincava e participava de jogos típicos de meninos, nos quais sempre assumia papéis masculinos; era agressiva e destrutiva, sua mãe não conseguia ser próxima dela; vestia-se com roupas de homem e só requisitava a companhia deles — apesar dos esforços da família para que se comportasse como uma menina, tudo falhou. Queria, inclusive, ser reconhecida como um menino. Na adolescência, passou por exames médicos e se constatou que era um menino cromossomicamente normal. Apesar da genitália externa se assemelhar a de uma menina, no fundo se tratava de um pequeno pênis do tamanho de um clitóris. Também apresentava hipospadia, criptorquidia bilateral, escroto bífido e próstata normal. Na adolescência, dizia se sentir atraído sexualmente por mulheres e que era em torno delas que giravam suas fantasias sexuais. Tinha prazeres, preocupações, atitudes e maneirismo típicos de um rapaz. Stoller salienta que não é que ele mudou sua identidade de menina para menino, mas que esta sempre foi masculina. Consta na descrição do caso que, antes de ser aceito como homem, reagia neuroticamente às pressões do ambiente - tais sintomas teriam cessado após a comprovação familiar de que se tratava de um menino. A partir de então, passou a atuar de forma "edipicamente" comum (mãe tomada como objeto de amor e pai como rival). Stoller conclui desse caso que a tentativa de criar o filho como uma menina, e mesmo o fato de ele possuir uma genitália de aparência feminina, não foram suficientes para o desenvolvimento da feminilidade - um impulso mais poderoso conduziu a criança para a masculinidade.

Contudo, Stoller confessava não saber como tais fatores orgânicos atuavam. Talvez essa tendência biológica em direção à masculinidade e à feminilidade trabalharia em silêncio no feto, e espera-se que, na maioria dos casos, elas sejam suplantadas pelos fatores ambientais, tal como Money e os Hampson pregavam — os fatores biológico e ambiental se manifestariam mais ou menos em harmonia para produzir a masculinidade em homens e a feminilidade em mulheres. Contudo, não é sempre assim; e Stoller (1968/1984, p. 19) divaga que, em algumas pessoas, as forças biológicas são mais determinantes do que em outras e suplantam os fatores ambientais. Mas, de toda forma, 
não era a descoberta de qual seria o fator universal mais vigoroso nesse processo o que o guiava. Stoller estava voltado à pesquisa do que denominou "núcleo de identidade de gênero", elemento esse a ser constituído por fatores heterogêneos. No caso dos sujeitos transexuais, a constituição do núcleo da identidade do gênero se daria exclusivamente por fatores psicológicos e é a essa tese que Stoller dedica sua pesquisa nos início dos $\operatorname{anos} 70$.

\subsubsection{Núcleo de identidade de gênero}

Stoller (1968/1984) afirma que o esperado é que, por volta dos dois anos, desenvolva-se o senso de pertencer a um sexo: a consciência que permite que afirmemos, pra nós mesmos, "Eu sou homem" ou "Eu sou mulher". Importante frisar que isso é diferente do senso de masculinidade ou feminilidade. Este diz respeito ao que se aprende sobre como homens e mulheres agem, é marcado pelas expectativas transmitidas pelos pais sobre como devemos nos comportar, é um atributo cultural. Já a constatação "Eu sou homem" ou "Eu sou mulher" é determinada biológica e psicologicamente e começa antes do "Eu sou masculino" ou "Eu sou feminino". Nota-se tal anterioridade quando verificamos certa dinâmica presente nos travestis fetichistas, tal como Stoller denomina, que podem se vestir, comportar-se, enfeitar-se como mulheres, contudo não afirmam serem, de fato, mulheres — seus "núcleos de identidade de gênero" (STOLLER, 1968/1984, cap. 4, p. 2) são masculinos. Os comportamentos de gênero podem mudar ao longo do tempo e dependem da cultura, mas a convicção de que se é homem ou mulher, não. Cabe salientar que identidade de gênero nuclear não determina papéis ou relações objetais, ou seja, não determina comportamentos de gênero, escolha de objeto e práticas sexuais (STOLLER, 1993, p. 29).

Esta formação identitária, o "núcleo da identidade de gênero", é válida tanto para meninos quanto para meninas; e, uma vez composta, é praticamente imutável. Sua constituição se daria a partir de três fatores: o primeiro diz respeito à relação pais e filho. Trata-se de atitudes, expectativas, gratificações, frustrações que os pais e parentes enviam à criança. Também consta desse primeiro fator a designação (ou assignação) dos pais de que seu filho é homem ou mulher, a partir da visão de sua genitália externa. $\mathrm{O}$ segundo diz respeito à percepção e às sensações que o órgão sexual fornece à criança — 
tal percepção contribui para a formação do ego corporal ${ }^{12}$. O terceiro fator contempla as forças biológicas em jogo.

Stoller confessa que tem dificuldade em saber o peso de cada um desses fatores para a formação da identidade de gênero nuclear, mas aponta que se a força de um deles cresce em detrimento da dos outros, desvios genéricos podem ser provocados. Em tese, os dois primeiros fatores seriam mais 'potentes'; porém, há casos que contradizem tal hipótese. Somente em um ponto Stoller é enfático: apesar da presença do órgão genital contribuir para a constituição de tal núcleo, ela não é essencial ${ }^{13}$.

Ao lado dessas proposições, Stoller apresenta outra, tão insistentemente enfocada ao longo de sua obra: o núcleo de identidade de gênero é fixado antes da fase fálica.

Enquanto o processo de desenvolvimento da identidade de gênero vai até a adolescência, o núcleo de identidade de gênero se estabelece precocemente. Stoller nunca descartou a concepção clássica de que a ansiedade de castração e a inveja do pênis sejam fatores fundamentais para a construção da identidade de gênero; contudo, antes da ocorrência desses efeitos, segundo ele, o núcleo de identidade de gênero já estaria estabelecido (STOLLER, 1968/1984, cap. 4, p. 2). Nesse sentido, Stoller contesta a teoria freudiana. Além do mais, ele se diz espantado com o fato de como um observador do gabarito de Freud pôde acreditar que o desenvolvimento da masculinidade e da feminilidade é o mesmo nos meninos e nas meninas até a fase fálica, até que "fatores biológicos" fizessem com que elas tomassem outro caminho ${ }^{14}$.

\footnotetext{
12 Stoller também inclui nesse segundo fator o processo de imprinting, tal como se manifesta nas experiências dos gansos de Lorenz. Daí Stoller considerar que humanos respondem sexualmente a humanos, não (ou nem tanto, em alguns casos) a outros animais ou objetos, em parte por conta de uma ainda obscura ação do sistema nervoso central que é produzida ou impressa pela mãe, dada sua qualidade de ser humana e mulher (STOLLER, 1968/1984, p. 10). Em um livro escrito sete anos depois, Sex and gender II (1975), no Brasil intitulado A experiência transexual (1982), Stoller soma àquele ainda outro processo, retirado do behaviorismo, no caso o que denominou 'reforço', 'modelagem' ou 'condicionamento': alguns comportamentos de gênero são encorajados pelo meio, enquanto outros são desvalorizados. Dessa maneira, ao lado dos fatores psicológico e biológico, há um outro, designado por Stoller como "biopsíquico" (imprinting e condicionamento) que também se faria presente.

${ }^{13}$ Stoller cita o caso de dois meninos que nasceram sem pênis e que tinham desenvolvido o núcleo de identidade de gênero masculino. Apresentavam maneirismos e interesses tipicamente masculinos. Esses dois meninos, quando hospitalizados, inventaram substitutos para seus pênis com os mesmos significados de agressividade e intrusão que se costuma atribuir a eles - o primeiro colecionava garrafas; o segundo, facas. Apesar de Stoller não arriscar uma hipótese sobre a causa determinante em jogo no ato dessas crianças, aqui se mostra que quando o menino sabe que ele é um homem, se não for dotado de um pênis, ele tenderá a instituir para si um objeto que funcione simbolicamente da mesma forma que tal órgão sexual. O núcleo da identidade de gênero se constitui independentemente da genitália em si. O que Stoller nota é que ela pode simbolicamente se materializar em outros objetos.

14 Stoller se refere a esta passagem do texto de Freud: "Se agora reconsideramos a parte do desenvolvimento sexual feminino que aqui foi descrita, não podemos nos furtar a uma conclusão sobre a
} 
Passemos então ao debate Stoller-Freud e, em seguida, à vertente do pensamento stolleriano que abarca os fatores psíquicos participantes da identidade de gênero. Para essa empreitada, recorre-se à transexualidade.

$\mathrm{Na}$ leitura de Stoller, Freud tomava a bissexualidade como um dado inato e universal. Seria como uma condição constitucional de todo ser humano, cujas raízes são biológicas e psicológicas, que influenciaria tanto a escolha de objeto quanto o grau de masculinidade e feminilidade — as pessoas seriam um misto dessas duas tendências. Stoller discorda: não existiriam raízes biológicas a determinar a bissexualidade; além do mais, para ele, as pessoas podem apresentar uma mescla de masculinidade e feminilidade, mas nunca uma mistura da qualidade de ser homem e da qualidade de ser mulher - essas últimas duas referentes ao núcleo da identidade de gênero. Outra crítica que Stoller endereça a Freud é que ele tomaria a qualidade de ser homem e a masculinidade como um estado primário - a qualidade de ser mulher e a feminilidade desfrutariam de status inferior. Além do mais, a menina teria um caminho mais tortuoso a percorrer para a constituição de sua identidade sexual do que o menino. Contra tudo isso, Stoller propõe que a bissexualidade não seja nem original nem biológica; que a masculinidade não seja primária e que o percurso edípico talvez não atue como o processo mais importante para a constituição da identidade sexual. Vejamos como.

Para Stoller, na vertente masculina do Édipo freudiano, o menino, na medida em que deseja a mãe, toma o pai como rival e se vê ameaçado pela perda de seu órgão genital - angústia essa alimentada pela visão dos órgãos genitais femininos. A ameaça de castração incide tanto na perda do órgão quanto na perda da qualidade de ser homem. Por fim, seus pais vêm ao seu auxílio para solucionar essa trama e deslocar seu investimento libidinal da mãe para outras mulheres; e seu pai lhe serve de modelo de identificação. Então, podemos ver aqui que a masculinidade e a heterossexualidade são essenciais e tomadas como dados a priori.

Já a menina, ainda acompanhando a leitura stolleriana de Freud, se depararia com maiores problemas: seus genitais são encarados como inferiores, o que culmina na inveja do pênis ${ }^{15}$; seu objeto de amor original é homossexual; sua feminilidade deve ser

sexualidade feminina como um todo. Encontramos as mesmas forças libidinais que havíamos encontrado nos meninos, e pudemos nos convencer de que durante um certo tempo elas tomam os mesmos caminhos e chegam aos mesmos resultados. Depois são fatores biológicos que as desviam de suas metas iniciais e conduzem pelas vias da feminilidade até mesmo tendências ativas, masculinas em todo sentido" (FREUD, 1931/2010, pp. 216-7).

${ }^{15}$ Tal como se lê em Freud: “As consequências psíquicas da inveja do pênis, na medida em que não é assimilada na formação reativa do complexo de masculinidade, são diversas e de largo alcance. Com o 
conquistada $^{16}$, não é um atributo dado de início e teria de haver uma mudança quanto ao órgão sexual a ser priorizado. Na melhor das hipóteses - quando a inveja não é excessiva, não se fixa a uma desesperança passiva e masoquista nem sustenta a fantasia de obter um pênis ou alçar o clitóris ao papel de substituto dele —, a menina adentra na feminilidade. Daqui pra frente, ela toma o pai como seu novo objeto de amor (ou seja, há um esforço para ir da homo para a heterossexualidade), o clitóris é deslocado pela vagina como seu principal órgão de investimento libidinal e, finalmente, identifica-se com a mãe. Mesmo assim, seriam poucas as meninas que teriam o privilégio de chegar a esse final feliz no seu processo edípico. De toda forma, a feminilidade é um estado secundário e o drama edípico é mais facilmente solucionado pelo menino do que pela menina.

Para dar corpo a seu argumento, Stoller (1968/1984, cap. 6) se mune do trabalho de outros teóricos, dizendo-se acompanhado de Horney, Jones e Zilboorg. As críticas a Freud se sustentam basicamente nas suas considerações de que, num primeiro momento, não existiria diferença psicossexual entre meninos e meninas. Jones, a esse respeito, recusa a postulação freudiana de que o fator comum para meninos e meninas na fase fálica é a crença de que só existiria um órgão sexual, o masculino. Horney critica duramente a ideia de que as mulheres são descontentes com a atribuição de seu sexo e que só sob certas circunstâncias superam tal "aborrecimento". Jones aponta que a importância dos órgãos genitais femininos sempre foi subestimada pela tradição psicanalítica falocêntrica - Stoller lança dúvidas a respeito da ideia de que o clitóris seja como um pequeno pênis, masculino, e mais ativo que a vagina. Além do mais, aposta que o senso de ser mulher e se sentir feminina não está atrelado à genitália. Assim, tais autores aos quais Stoller recorre também propõem revisões à teoria freudiana e argumentam que formações como inveja do pênis e o ódio aos homens seriam secundárias - a feminilidade seria primária e só a saída da womanhood criaria os fatores necessários para que uma mulher reconhecesse e se confrontasse com a diferença masculina.

reconhecimento da ferida narcísica, produz-se na mulher - como uma cicatriz, por assim dizer - um sentimento de inferioridade. Depois de haver superado a primeira tentativa de explicar sua falta de pênis como castigo pessoal e haver apreendido a universalidade dessa característica sexual, ela começa a partilhar o menosprezo do homem por um sexo reduzido num ponto decisivo, e ao menos nesse juízo permanece equiparada ao homem" (FREUD, 1925/2011, pp. 262-3).

16 “[frente à castração] Num instante ela faz seu julgamento e toma sua decisão. Ela viu, sabe que não tem e quer ter. Neste ponto se separa o chamado complexo de masculinidade da mulher, que eventualmente reservará grandes dificuldades ao desenvolvimento prescrito rumo à feminilidade, caso não seja logo superado" (FREUD, 1925/2011, p. 262). 
Ao lado dessas críticas, o embate forte que Stoller trava com a psicanálise clássica se dá a partir da consideração de que Freud não teria dado a devida importância ao período pré-edípico. Segundo Stoller, seu conceito de identidade de gênero nuclear modifica a teoria freudiana. Haveria um estágio anterior ao Édipo, momento no qual o menino estaria "fundido com a mãe" (STOLLER, 1993, p. 35). Mãe e filho ainda não seriam objetos separados e este se sentiria como uma parte do corpo dela, o que o conformaria à feminilidade. Caso esse estado não seja superado, corre-se o risco de ser implantada na sua identidade de gênero nuclear a qualidade ou senso de ser mulher. A não separação da mãe provoca distúrbios de gênero, sendo a transexualidade seu caso mais extremo.

Essa teoria da protofeminilidade ${ }^{17}$ deslocaria a "vantagem" do menino para a menina. A qualidade do vínculo inicial com a mãe induz a menina à feminilidade, facilita a formação de sua identidade como mulher. Só que o mesmo não se dá para o menino. Então, é ele quem tem de lançar mão de um esforço maior para a constituição de sua identidade de gênero masculina. Ele deve se encontrar suficientemente separado de sua mãe para entrar no Édipo, acessar a heterossexualidade e a masculinidade, superando aquele estado feminilizante inicial. A masculinidade é uma conquista, não é um estado natural a ser mantido ${ }^{18}$.

Essa teoria stolleriana tem o mérito de questionar concepções da psicanálise tradicional que sustentam o julgamento de que as mulheres são inferiores aos homens. Stoller é contra o falocentrismo; contra a centralidade da inveja do pênis na sexualidade feminina; contra a concepção de que o clitóris é uma versão menor do pênis; contra as teses de que o acesso à feminilidade é mais duro e raro para mulheres do que a masculinidade para os homens e de que, como resultado da diferença anatômica entre os sexos, as mulheres possuem um senso ético diferente do dos homens como fruto de seus superegos ou senso de justiça $\operatorname{man} \cos ^{19}$; e, por fim, contra as suposições de que a

\footnotetext{
${ }^{17}$ Outro argumento em prol da feminilidade primária deriva da biologia: somente se o cérebro fetal for organizado pelo andrógeno, produz-se um corpo masculino e o fundamento da masculinidade (embriologicamente falando, o pênis seria um clitóris masculinizado; o cérebro masculino, um cérebro feminino androgenizado) — haja vista a síndrome de insensibilidade andrógena (feminilização testicular) (STOLLER, 1982, p. 14).

${ }^{18}$ A hipótese stolleriana de que a condição de homem é algo a ser adquirido é corroborada por estudos antropológicos analisados por ele, como os realizados junto à tribo dos Sâmbia, da Nova Guiné: um dos ritos pelos quais os meninos devem se submeter para se tornarem masculinos é ingerir o sêmen de homens solteiros, via felação (STOLLER, 1993, pp. 250-1), assim como evitar o contato com as mulheres na infância e na adolescência. Ou seja, tornar-se homem exige um longo trabalho de dedicação.

${ }^{19}$ Nesse sentido, Freud afirma: "Hesitamos em expressar isto, mas não podemos nos esquivar da noção de que o nível do que é eticamente normal vem a ser outro para a mulher. O Supereu jamais se torna tão
} 
feminilidade é algo depreciativo para elas e de que ficam decepcionadas quando constatam que não vão ter um pênis.

Depois de se dedicar ao estudo de casos de intersexo em sua pesquisa sobre as condições de desenvolvimento da masculinidade e da feminilidade e ter constatado a influência de fatores biológicos nesse processo, Stoller vai para o outro lado e passa a se interessar mais, notadamente nos anos 70, pelo papel dos fatores ambientais ou pósnatais na constituição da identidade de gênero. Para tanto, Stoller passa a focar sua pesquisa na transexualidade. O motivo para tal escolha é que se trataria de um quadro clínico de formação identitária não determinada por forças biológicas. Transexuais seriam sujeitos que não apresentariam disfunções anatomofisiológicas, endócrinas ou genéticas que levariam a um distúrbio de gênero. Ou seja, um quadro clínico que escancararia a determinação dos fatores ambientais ou pós-natais para a constituição identitária sexual. Além do mais, segundo Stoller, a transexualidade contesta as teses clássicas da psicanálise de que a ansiedade de castração e o complexo de Édipo — ou seja, processos relacionados ao tema do conflito - são os estandartes da constituição da masculinidade e da feminilidade. Stoller se pauta na hipótese de que um processo não conflitivo - segundo ele, não contemplado por Freud — é que seria determinante para a formação do núcleo da identidade de gênero.

Stoller acreditava que existiria um contínuo entre os distúrbios de gênero: um dos extremos seria a transexualidade. Enquanto perversão de identidade de gênero, travestismo fetichista - nos seus termos - e homossexualidade são frutos de conflitos e defesas, a transexualidade, não: "vejo o transexualismo como uma identidade per se" (STOLLER, 1982, p. 2).

O sujeito transexual, na ótica stolleriana, não distorce a percepção do seu corpo; tem conhecimento do seu sexo; ao mesmo tempo, relata ter a convicção ou sentimento de que pertence ao gênero oposto ao que o seu corpo indica. Um transexual masculino $^{20}$, por exemplo, é biologicamente um homem; porém, afirma que sua identidade de gênero é feminina.

inexorável, tão impessoal, tão independente de suas origens afetivas como se requer que seja no homem. Traços de caráter que sempre foram criticados na mulher - que ela mostra menos senso de justiça que o homem, menor inclinação a submeter-se às grandes exigências da vida, que é mais frequentemente guiada por sentimentos afetuosos e hostis ao tomar decisões - encontrariam fundamento suficiente na distinta formação do Supereu que acabamos de inferir. Em tais juízos não nos deixaremos influenciar pela contestação dos partidários do feminismo, que desejam nos impor uma total equiparação e equivalência dos sexos [...]" (FREUD, 1925/2011, pp. 267-8).

${ }^{20}$ Pelo termo "transexual masculino", Stoller se referia a um sujeito cujo corpo de nascença era biologicamente masculino e cuja identidade sexual era feminina, ou seja, Stoller pautava-se pelos 
Após muitos atendimentos com transexuais e seus parentes, Stoller detecta certo padrão nas dinâmicas familiares em que um filho é transexual ${ }^{21}$, no qual uma rara coincidência de fatores ocorre: a mãe é cronicamente deprimida, apresenta intensa inveja do pênis e desejo apenas parcialmente suprimido de ser homem; o pai é distante, física e psicologicamente, e passivo; estabelece-se entre mãe e filho uma simbiose feliz, vínculo mais intenso do que o que se costuma observar na maternagem comum - o contato físico é excessivo e se firma um prolongado laço sem hostilidade ou frustrações, não movido por desejo sexual, mas identificação (eles são praticamente um, o filho é o falo da mãe e abranda a depressão dela); o pai não o rompe, pelo contrário, chega a encorajá-lo; esse filho é escolhido para ser enredado nessa simbiose por apresentar uma beleza fascinante. Consequentemente, o menino não entra no Édipo, não toma seu pai como rival e sua mãe como objeto de desejo, ficando preso à feminilidade primária - a masculinidade não se desenvolve. Pode-se dizer, então, que o senso de ser mulher do transexual masculino se deu livre de conflitos ou traumas.

Usando termos comuns aos de Winnicott, como "mães suficientemente boas", Stoller aponta que "mães boas demais", e não só as que não são suficientemente boas, causam problemas aos filhos. Mães superpoderosas e superprotetoras são comuns nas dinâmicas familiares de filhos homossexuais. No caso dos transexuais, aquela longa "simbiose feliz" traz como consequência um "distúrbio profundo no ego corporal da criança, pelo que ele se sente como sendo, de alguma forma, mulher, apesar de ter conhecimento de que é um homem" (STOLLER, 1982, p. 54). E mais adiante Stoller (1982, p. 55) conclui seu diagnóstico: "essas mães não danificam o desenvolvimento das funções do ego em geral, ou mesmo do ego corporal, exceto em relação a esse senso de feminilidade". Ao contrário do que se poderia esperar, transexuais masculinos, segundo Stoller, não são meninas edipianas: não são românticas, sedutoras de seus pais, não tomam a mãe como rival e como futura fonte de identificação. $\mathrm{O}$ menino transexual

caracteres anatomofisiológicos para o estabelecimento dos termos transexuais masculinos ou femininos. Hoje em dia, a tendência é oposta, a primazia é do gênero. Então, o termo "mulher transexual", por exemplo, indica um sujeito cujo sexo de nascimento é masculino e manifesta o gênero sexual feminino. Para evitar maiores confusões de leitura, optamos seguir a terminologia do autor em foco.

${ }^{21}$ Segundo Stoller (1982, p. 223), há diferenças clínicas contundentes entre as versões masculina e feminina da transexualidade, tanto dinâmica quanto etiologicamente. A respeito do transexualismo feminino, Stoller é mais cauteloso quanto à construção de uma teoria — trata-se de um caso mais raro que o masculino, segundo ele, e ao qual se dedicou menos. 
teria como foco de dedicação a construção de uma aparência feminina (STOLLER, 1982, p. 96) ${ }^{22}$.

De toda forma, Stoller conclui que, em geral, quanto mais intensa e prolongada é a simbiose inicial mãe-bebê, mais feminino o menino será. Um pai forte e masculino deve impedir o prolongamento daquele laço e separar o menino do corpo e da psique da mãe, ajudando-o a desenvolver a identidade masculina. Separado da mãe, o filho a reconhece como um ser do outro sexo, pode passar a desejá-la e se defrontar com o conflito edípico. No caso das meninas, a simbiose mãe-filha não deve ser rompida rapidamente - ela deve ser alimentada, já que promove a feminilidade. Sem tais procedimentos, não há desenvolvimento da masculinidade nem da feminilidade (STOLLER, 1993, p. 90).

Mas existe outro ponto: para o rompimento dessa simbiose, há também de se levar em conta a contribuição que o menino deve operar: Stoller presumia que haveria forças biológicas (séries complementares de Freud) que os compeliriam, mais em alguns meninos do que em outros, a escapar da simbiose e a superar a protofeminilidade. $\mathrm{O}$ menino construiria barreiras intrapsíquicas contra seu próprio desejo de se manter fundido à mãe. $\mathrm{O}$ desenvolvimento dessas barreiras é fruto de fatores biológicos, habilidades aprendidas e prazer em tomar a via da masculinidade, que anda ao lado do encorajamento do meio ao menino tomar tal partido, incentivandoo a não só desenvolver, mas também a preservar a masculinidade. O menino criaria um escudo protetor contra a "ansiedade de simbiose" (STOLLER, 1993, p. 243).

O grau de feminilidade que se desenvolve em um menino depende também de outros pontos da dinâmica familiar a que ele foi submetido na infância, de características da mãe e do pai e da relação estabelecida entre eles. Stoller parece operar com variações sobre o mesmo tema. Os mesmos critérios que os observados nas famílias de filhos transexuais servem de referência geral. Eles, em menor grau de intensidade ou com um colorido diferente, supostamente causariam distúrbios de gênero menos graves que a transexualidade. Por exemplo, se a mãe ama o pai; se a simbiose não é tão intensa; se os comportamentos femininos do filho não são tão valorizados; se a

\footnotetext{
${ }^{22}$ Stoller também mostra que diferentes tipos de laços simbióticos estão na base das diferenças etiológicas entre o transexual masculino, o travesti fetichista e homossexual masculino. Nos travestismos não há a intensidade da simbiose transexual, mas um progressivo distanciamento da mãe e desenvolvimento da masculinidade do filho; contudo, esse processo é combatido por uma mulher (vestindo-o com roupas femininas, por exemplo), com a finalidade de dificultar a aquisição do senso de masculinidade. Já na homossexualidade masculina há um misto de excessiva gratificação e punição quando o menino expressa sua masculinidade (STOLLER, 1982, p. 159). Nesses dois quadros, o núcleo de identidade de gênero é masculino e tende a ser preservado. Na transexualidade masculina, não.
} 
mãe é feminina em alguns aspectos; se o menino é bonito, mas não lindo; se o pai não está tão ausente assim, por exemplo, produziriam graus de feminilidade inferiores aos que se nota em sujeitos transexuais.

Outro ponto a ser destacado é que Stoller evita discutir sua teoria a partir do kleinismo, pois, segundo ele, a literatura dessa corrente psicanalítica não trata do desenvolvimento da masculinidade e da feminilidade (STOLLER, 1982, p. 36). Além do mais, Klein se dedica especialmente às fantasias do bebê; Stoller, por sua vez, acreditava que não existiria, nos primeiros meses de vida, aparato psíquico estabelecido ao ponto de suportar uma intricada carga fantasística. Daí Stoller recorrer a operações como imprinting e influências condicionadoras, mais fisiológicas, que não exigem grandes desenvolvimentos psíquicos. No princípio, a mãe invade o filho e, nesse período inicial, o filho ainda não foi capaz de produzir um escudo fantasístico que funcionaria como defesa (STOLLER, 1982, pp. 51-3). Nessa relação simbiótica não se trataria de uma identificação clássica - já que esta requer recursos de fantasia e memória - mas de um tipo de transmissão da feminilidade na qual o filho a recebe passivamente, fruto da excessiva imposição dos corpos, vivida de forma tão gratificante que nenhuma forma de proteção precisaria ser erguida contra ela (STOLLER, 1982, p. $55)$.

No final de A experiência transexual (1982), Stoller parece rever sua consideração anterior de que as versões masculina e feminina do núcleo de identidade de gênero têm a mesma estrutura. Paira sobre o homem a atração a regressar à primitiva e feminilizante unidade com a mãe. Existe um conflito formado sobre o senso de virilidade, conflito esse de que as mulheres não padeceriam — o núcleo de identidade de gênero masculino não é tão imutável como Stoller acreditou incialmente (STOLLER, 1982, p. 297). E afirma: "O senso de virilidade e o desenvolvimento posterior, masculinidade, são um pouco menos firmemente estabelecidos em homens do que o senso de feminidade e a feminilidade nas mulheres" (STOLLER, 1982, p. 299). A simbiose da menina com a mãe fortalece o senso de feminidade. Já para o menino, tal laço o torna vulnerável à "tentação" de retorno e sua masculinidade pode ser posta em perigo. Stoller levanta a hipótese de que talvez seja por isso que homens sejam mais propensos à perversão que as mulheres, o que o fez enveredar para a pesquisa desse quadro, das dinâmicas da excitação sexual e da pornografia, no que tange a identidade sexual. Grosso modo, no homem, a fuga para a pornografia, a fetichização e a erotização do ódio contra mulheres seriam estratégias de proteção contra a tentação de 
retorno à fusão inicial com a mãe e sua consequente feminilização e perda de masculinidade (STOLLER, 1998, pp. 48-9).

Então, para Stoller, a constituição da identidade de gênero e a determinação da diferença sexual são explicadas por fatores relacionados ao sexo biológico, ao papel da atribuição de significados efetuada pelo outro — de que se trata de um homem ou mulher -; por expectativas do meio social, fenômenos etológicos ou de condicionamento; por formações egoicas e imaginárias e pela qualidade do vínculo simbiótico feminilizante com a mãe. Stoller defende a importância do período préedípico e, através de diversas manifestações da sexualidade, constrói sua tese a respeito do "núcleo da identidade de gênero", posta em xeque tanto por Lacan quanto por Butler.

Lacan, no Seminário XVIII se refere a Sex and gender de Stoller. Incialmente para criticar seu entendimento da transexualidade, depois para contestar a suposição de que existiria, de fato, um núcleo duro no que diz respeito à identidade de gênero. Para esse debate, Lacan recorre à noção de semblante.

\subsection{A noção de semblante}

Há, na língua francesa, variados usos para o termo 'semblante', na maioria das vezes referidos à ideia de falso, simulacro, engano ou fingimento. Expressões como faire semblant ou ainda faire semblant de rien são portadoras dessa marca negativa, de certa aparência que insiste em dissimular a verdade — nesse sentido, a verdade deveria ser procurada por trás das aparências, pois o que se mostra é sempre ilusório. Na psicanálise, as considerações sobre o semblante não tomam essa vertente do engodo.

Nusinovici (2008) aponta que semblante se refere ao que imita ou representa, de um modo fictício, uma coisa real. A partir do século XVI, o valor negativo ligado à ideia de aparência predomina. Lacan recupera, então, o sentido de semblante anterior a este período e volta a lhe dar boa aparência. O semblante não é a imitação ou a representação de uma coisa real. Nem uma aparência, um fenômeno, para além da qual haveria a coisa em si.

A noção de 'aparência' ou 'semblante' nunca foi um tema que mereceu grande destaque na obra lacaniana. Até que, no Seminário XVIII, há uma reviravolta e Lacan passa a atrelar o semblante à verdade. "A verdade não é o contrário do semblante [...]. A diz-mansão da verdade sustenta a do semblante" (LACAN, 1971/2009, pp. 256). O semblante é dialeticamente ligado à verdade, suportado por ela, sem o qual não é 
possível caracterizar o que se passa no discurso. É através do semblante que podemos tocar a verdade.

'Semblante' diz respeito ao lugar no qual constituímos autorias; o semblante se reconhece em um significante — daí sua relação com o falo e a prática de nomeação. Mas, mesmo constando na ordem significante, o semblante não se reduz a ela - seu terreno é o da interceptação entre simbólico e real.

No final do Seminário III, Lacan lança mão do exemplo do arco-íris, a ser retomado no XVIII, tomando-o, ao lado do trovão e do meteoro, como paradigma do semblante. Se o arco-íris está inteiramente em sua aparência, nosso interesse por ele só existe porque tal fenômeno é nomeado - nenhum animal se encanta pelo arco-íris: “[...] há um momento em que lhe dizemos: $O$ arco-íris, é isso. E este é isso supõe a implicação de que vamos nos comprometer nisso até que percamos o fôlego, para saber o que há de escondido atrás [...]" (LACAN, 1955-56/1998, p. 357). Contudo, não há nada escondido atrás; ele está inteiramente reduzido à sua aparência. Se o arco-íris não tiver um nome, "esse lago não tem outro recurso senão lhe mostrar as mil miragenzinhas do brilho do sol nas vagas e nos rastos de vapores úmidos que se depreendem" (LACAN, 1955-56/1998, p. 357). O arco-íris é uma ilusão da qual um significante faz semblante. O nome que sustenta a figura do semblante é o representante de um real que, enquanto tal, é sem representação.

Também há uma distinção a ser feita entre 'véu', 'máscara' e 'semblante'. Apesar de serem noções próximas, carregam profundas diferenças entre si. A noção de 'véu' designa um artifício a partir do qual o sujeito se relaciona com a falta de objeto tomando a "essência como aparência", da qual se deduz diversas manifestações perversas, tal como Lacan expõe no Seminário IV. A máscara é um recurso característico da feminilidade, no qual há "aparência como essência" — aqui a mascarada feminina descrita por Joan Rivière é lida por Lacan como um recurso fálico que velaria o nada que apontaria para o próprio da feminilidade; a mulher abriria mão de uma parcela de sua feminilidade para a construção, processo fálico, da mascarada. Já o semblante seria a "aparência como aparência", permitindo um "como se": reconhecese que por trás da aparência não há essência, mas se faz "como se" houvesse (DUNKER, 2008). A importância dessa noção chega ao ponto de Lacan, revendo sua teoria dos discursos, renomear o lugar do agente como o lugar do semblante: todos os discursos (discursos do mestre, universitário, da histeria e o do psicanalista) são 
ordenados agora a partir do semblante. Ou, em outra medida, todo discurso se dá como semblante.

Se nos laços sociais previstos pela teoria dos discursos a sexualidade estava suspensa, agora temos esta novidade: a verdade se "sexualiza" a partir do semblante. Ao mesmo tempo em que o semblante é uma noção que diz respeito à teoria dos discursos, em sua relação com a verdade introduz a diferença sexual. Dá-se o passo na direção da sexuação.

Importante frisar que a verdade não tem conteúdo. A oposição entre verdade e semblante não é a mesma que entre verdadeiro e falso. A verdade, por meio da linguagem, se aproxima do real. A seu respeito, não se trata de conhecimento, mas de indução lógica, indução de algo real. E Lacan imiscui nesse debate as categorias de homem e mulher.

Vejamos os desdobramentos de tal reviravolta em Lacan.

\subsubsection{Semblante, diferença sexual e performance}

Seguindo no Seminário XVIII, Lacan, após criticar o "caráter inoperante do aparato dialético" (LACAN, 1971/2009, p. 30) utilizado por Stoller para explicar os casos de seus pacientes transexuais - justamente por, para o psicanalista francês, ele ter negligenciado o mecanismo da foraclusão e a psicose latente de tais sujeitos ${ }^{23}$-, discorre sobre a identidade de gênero stolleriana. Trata-se de "parecer" homem ou mulher:

O importante é isso: a identidade de gênero não é outra coisa senão o que acabo de expressar com estes termos, "homem" e "mulher". É claro que a questão do que surge precocemente só se coloca a partir de

\footnotetext{
${ }^{23}$ Lacan afirma no Seminário XVIII: "Chama-se Sex and Gender [Sexo e gênero], de um certo Stoller. É muito interessante de ler, primeiro porque desemboca num assunto importante - o dos transexuais, com um certo número de casos muito bem observados, com seus correlatos familiares. Talvez vocês saibam que o transexualismo consiste, precisamente, num desejo muito enérgico de passar, seja por que meio for, para o sexo oposto, nem que seja submetendo-se a uma operação, quando se está do lado masculino. No livro vocês certamente aprenderão muitas coisas sobre o transexualismo, pois as observações que se encontram ali são absolutamente utilizáveis. Aprenderão também o caráter completamente inoperante do aparelho dialético com que o autor do livro trata essas questões, o que o faz deparar, para explicar seus casos, com enormes dificuldades, que surgem diretamente diante dele. Uma das coisas mais surpreendentes é que a face psicótica desses casos é completamente eludida pelo autor, na falta de qualquer referencial, já que nunca lhe chegou aos ouvidos a foraclusão lacaniana, que explica prontamente e com muita facilidade a forma desses casos (LACAN, 1971/2009, p. 30)". Em Corpo em obra: contribuições para a clínica psicanalítica do transexualismo (COSSI, 2011, nVersos), discutimos essa apreciação de Lacan e a relação direta que passou a ser estabelecida na tradição lacaniana entre transexualidade e psicose.
} 
que, na idade adulta, é o próprio destino dos seres falantes distribuírem-se entre homens e mulheres. Para compreendermos a ênfase depositada nessas coisas, nesse caso, é preciso nos darmos conta de que o que define o homem é sua relação com a mulher, e vice-versa. Nada nos permite abstrair essas definições do homem e da mulher da experiência falante completa, inclusive nas instituições em que elas se expressam, a saber, no casamento. Para o menino, na idade adulta, trata-se de parecer-homem. É isso que constitui a relação com a outra parte. É à luz disso, que constitui uma relação fundamental, que cabe interrogar tudo o que, no comportamento infantil, pode ser interpretado como orientando-se para esse parecer-homem. Desse parecer-homem, um dos correlatos essenciais é dar sinal à menina de que se o é. Em síntese, vemo-nos imediatamente colocados na dimensão do semblante. (LACAN, 1971/2009, pp. 30-1)

Lacan afirma que a sexualidade humana não é determinada pela anatomia, fisiologia ou pela genética, nem adota a reprodução sexual como imperativo. A linguagem também não a esgota e rituais, instituições culturais - como o casamento, por exemplo —, são ineficazes para demarcar homem e mulher. Também não é a operação de nomenação (você é uma menina! Você é um menino!) o que permite ao sujeito assegurar-se como um ou outro. A identificação sexual não consiste em se crer homem ou mulher, mas em levar em conta que há meninas, no caso dos meninos, e que existem meninos, para as meninas (LACAN, 1971/2009, p. 33). Nesse sentido, o homem só pode ser definido como tal em relação à mulher, e vice-versa — há de se levar em conta a diferença e que um só existe em relação ao outro. Os gêneros não têm substância intrínseca a eles. E aqui entra o semblante na sua dimensão sexualizada: trata-se de "parecer-homem" ou "parecer-mulher". Essa dimensão discursiva e dialética do semblante sexual questiona a ideia de que um gênero se constitui por si só, sem o seu respectivo oposto e sem o reconhecimento do outro sexo.

Lacan pontua que, no campo da etologia, também se trata do semblante: no caso dos mamíferos superiores, a copulação se dá, na maioria dos casos, suscitada por uma exibição prévia do macho em direção à fêmea. A relação sexual humana também conta com a aparência nessa função. A distinção entre eles virá por outro ângulo. Comparando o comportamento sexual humano com a exibição animal, Lacan afirma:

A única coisa que o diferencia dela é que esse semblante seja veiculado num discurso, e que é neste nível de discurso, que ele é levado, permitam-me dizer, para um efeito que não fosse semblante. Isto significa que, em vez de ter a refinada cortesia animal, sucede aos homens violar uma mulher, ou vice-versa. Nos limites do discurso, na medida em que ele se esforça por fazer com que se mantenha o 
mesmo semblante, de vez em quando existe o real. É a isso que chamamos passagem ao ato. (LACAN, 1971/2009, p. 31)

Por mais que uma vertente do comportamento sexual humano também se sustente em exibições do tipo semblante animal, o semblante humanizado é difundido em um discurso, e é nesse nível que ele é conduzido para um efeito que não fosse semblante. Deriva disso o humano ser regido por um gozo excessivo, desregulado, que pode desembocar numa violência muito particular.

Avançando na discussão, Soler aponta que a diferença entre os sexos também se faz notar no que tange ao semblante fálico, “[...] um desfila como desejante, a outra como desejável [...]. De um lado, portanto, a exibição ostentatória [...]. Do outro, a armadilha disfarçada [...]. As maneiras variam, é claro, mas persiste a estrutura que sempre envolve o ponto de falta do sujeito [...]" (SOLER, 2005, p. 32). Na mascarada feminina, trata-se de se fazer desejar, moldar-se às condições de desejo do homem - o que deseja, o que tem e quer dar as provas de sua potência —, numa parada viril. A visão de Soler permite pensar que semblante-homem e semblante-mulher estariam em relação na qual a complementariedade seria possível. Contudo, a tese da autora não leva em conta a verdade e o real em jogo do lado 'mulher' que implementam a dissimetria nesse nível.

Para o homem, nessa relação, a mulher é precisamente a hora da verdade. No tocante ao gozo sexual, a mulher está em condição de pontuar a equivalência entre gozo e semblante. É justamente nisso que jaz a distância a que o homem se encontra dela. Se falei em hora da verdade, é por ser a ela que toda a formação do homem é feita para responder, mantendo, contra tudo e contra todos, o status de seu semblante. É certamente mais fácil para o homem enfrentar qualquer inimigo no plano da rivalidade do que enfrentar uma mulher como suporte dessa verdade, suporte do que existe de semblante na relação do homem com a mulher. (LACAN, 1971/2009, p. 33)

Pode-se dizer, então, que a mulher denuncia para o homem que o gozo dele vincula-se ao semblante; denuncia que o semblante, cuja edificação é fálica, está em jogo nas relações que estabelece — esse é o seu terreno familiar. Tal cenário se desestabilizaria com a entrada da mulher, representante do teste de verdade para ele - a verdade só pode ser semidita, tem uma parcela de real, cuja infiltração, no caso, é encarnada pela mulher. Ela desequilibra os alicerces fálicos nos quais o homem se escora. Daí ser mais fácil para ele, segundo Lacan (1971/2009, p. 33), enfrentar um rival 
homem - e, nesse contexto, dar provas de sua masculinidade via semblante — do que encarar uma mulher e o desnudamento do espaço que o semblante é incapaz de recobrir.

Adiante, Lacan (1971/2009, p. 34) continua: "Ninguém, senão a mulher — porque é nisso que ela é o Outro - sabe melhor o que é disjuntivo no gozo e no semblante [...]". 'Homem' é atrelado a semblante, campo fálico. 'Mulher' é pensada em sua relação com a verdade, o que já nos parece ser um prenúncio do gozo feminino. Semblante e verdade estabelecem uma relação ao serem traduzidos para o universo da diferença sexual. Ou melhor, já anunciam uma não relação.

Se, nos anos 50, Lacan concebia a diferença sexual em termos de ser o falo (mulher) e ter o falo (homem), e no início desse Seminário XVIII fala em parecerhomem e parecer-mulher - formulações que permitem conceber a pressuposição de uma relação entre os sexos —, agora, quando entramos com a noção de semblante afetada pela verdade, Lacan dá um passo que nos parece ser decisivo e sem recuos, ao enunciar que a relação sexual não existe, já nesse mesmo Seminário XVIII — o que será, nos próximos, tratado com grande rigor conceitual.

O discurso é semblante e não importa do quê. O que ocorreria no caso onde isso não fosse semblante? Aqui entramos no campo da repetição e do gozo (LACAN, 1971/2009, p. 19). Um discurso que não é semblante é um discurso impossível, seu efeito é um mais-de-gozar e funciona como real (LACAN, 1971/2009, p. 21). Nesse mesmo ano, Lacan afirma:

Trata-se da indução de algo que é completamente real, ainda que não possamos falar disso como significantes, quero dizer, que não têm outra existência a não ser como significantes. De que estou falando? Ora, de nada além do que é chamado, na linguagem corrente, de homens e mulheres. Não sabemos nada de real sobre esses homens e mulheres como tais. [...] Homens e mulheres, isso é real. (LACAN, 1971/2011, p. 57)

Homem e mulher, cada um está no discurso a título de semblante. Mas há algo além do discurso, cujo registro é real e o campo, do gozo. "O falo é, muito propriamente, o gozo sexual como coordenado com um semblante, como solidário a um semblante" (LACAN, 1971/2009, pp. 32-3). A referência comum ao gozo sexual vem de alguma forma recobrir o mais-de-gozar singular de cada um dos parceiros. A mulher pode ser o falo para o homem, assim como o homem também pode sê-lo para ela: cada um podendo encarnar para o outro, por certo tempo, o gozo sexual, sob a suposição de 
um gozo comum - suposição, porque a disparidade entre gozo fálico e gozo Outro decreta a não relação sexual.

E como pode ser concebida essa não relação? Uma relação só existe na medida em que ela pode ser escrita, um discurso não basta para estabelecê-la. A relação sexual humana não pode ser escrita porque sua fundamentação se dá no campo do gozo. Em Freud, tudo o que é da linguagem mantém relação com o sexo, porém a relação sexual não pode se inscrever nela.

A pretensa sexualização das funções que podemos chamar de subjetivas, e que seria realizada pela doutrina freudiana, sob a condição de situá-las na ordem da linguagem, consiste essencialmente em que o que deveria resultar da linguagem, ou seja, a possibilidade de a relação sexual se inscrever nela de algum modo, mostra de forma precisa, e na realidade, seu fracasso. Ela não é inscritível. (LACAN, 1971/2009, pp. 122-3)

Cabe ressaltar que Lacan diz 'inscritível', e não 'enunciada'. Ou seja, não há a escrita dessa função na linguagem, ela não relaciona logicamente estes dois polos 'homem' e 'mulher', tal como veremos a partir dos desdobramentos dos próximos seminários de Lacan.

Por fim, retomemos: 'homem' e 'mulher' são fatos de discurso, e só há discurso de semblante. O semblante só se enuncia a partir da verdade; mas, no contexto da verdade, a relação sexual fracassa. Estamos no universo do gozo, fálico e Outro; fora da linguagem e, como tal, da escrita.

Mas a escrita em si, não a linguagem, a escrita provê de ossos todos os gozos que, por meio do discurso, mostram abrir-se ao ser falante. [...] a relação sexual falta no campo da verdade, posto que o discurso que a instaura provém apenas do semblante, por só abrir caminho para os gozos que parodiam - essa é a palavra adequada - aquele que é efetivo, mas que lhe permanece alheio. Assim é o Outro do gozo, para sempre proibido, inter-dito, aquele cuja habitação a linguagem só permite ao lhe fornecer - por que eu não haveria de empregar esta imagem? - escafandros. (LACAN, 1971/2009, p. 139)

Ao gozo Outro, que ex-siste, só cabe parodiar o gozo fálico. A escrita lógica prevê recursos para além da linguagem na tentativa de escrever a não relação sexual promulgada pela incomensurabilidade das experiências de gozo. Mais adiante tais passagens serão esmiuçadas. 
Se Stoller foi importante para Lacan no desenvolvimento de sua teoria do semblante, também o foi para Butler, para seu estabelecimento de gênero enquanto performance.

A filósofa questiona o caráter substantivo e pré-discursivo que Stoller atribui ao gênero quando pensado em termos de "núcleo". Para ela, tomar o gênero como uma substância permanente é uma ficção. Além do mais, algo sempre escapa à tentativa de delimitação do conjunto de traços adjetivos que o comporiam:

Se a noção de uma substância é uma construção fictícia, produzida pela ordenação compulsória de atributos em sequência de gênero coerentes, então o gênero como substância, a viabilidade de homem e mulher como substantivos, se vê questionado pelo jogo dissonante de atributos que não se conforma aos modelos sequenciais ou causais de inteligibilidade. (BUTLER, 1990/2003, p. 47)

A substância de gênero está na base da formulação do conceito stolleriano de "núcleo de identidade de gênero". E Butler continua:

Desse modo, a aparência de uma substância permanente ou de um eu com traços de gênero, ao qual o psiquiatra Robert Stoller se refere como o "núcleo do gênero", é produzida pela regulação dos atributos segundo linhas de coerência culturalmente estabelecidas. E resulta que a denúncia dessa produção fictícia é condicionada pela interação desregulada de atributos que resistem à sua assimilação numa estrutura pronta de substantivos primários e adjetivos subordinados. (BUTLER, 1990/2003, p. 47-8)

O que foge à coerência de gênero, o que é excluído - ou os "adjetivos dissonantes", nas palavras de Butler (1990/2003, p. 48) - poderia, em tese, ser reassimilado, chegando até a provocar alterações nas categorias substantivas de gênero. Mas não é disso que se trata. O que importa para Butler é mostrar que a coerência é contingencial, forjada a partir da regulação dos atributos adjetivos — tomar gênero como uma entidade ontológica é uma manobra artificial e de poder, que serve estrategicamente para ocultar o verdadeiro caráter do gênero. Nesse caso, para Butler, nem substância nem acúmulo de "atributos flutuantes" (BUTLER, 1990/2003, p. 48): o gênero é performativo.

Outra crítica que a filósofa endereça a interpretações do gênero como a de Stoller é a de que elas operam na binaridade homem/mulher, masculino/feminino. Partem da concepção de que o binarismo é um dado natural e pré-discursivo, o que fecha as portas para manifestações de gênero imprevisíveis e inovadoras. E mais, 
tendem a patologizar o que não se enquadra nos moldes de tal binaridade e da harmonia entre sexo e gênero.

Pensamos que combater o pressuposto stolleriano de que haveria um núcleo de identidade sexual ajuda Lacan e Butler a defender a concepção de que tal substância é uma ilusão.

"Autorizando-se por eles mesmos como seres sexuados, segundo uma expressão do seminário Les non-dupes errent, os sujeitos são coagidos a isso pela falha do inconsciente que fala. Maldição! Ela dá infelicidade [mal-heur], porque o inconsciente diz mal do Sexo [...]" (SOLER, 2005, p. 139). Se o sujeito é levado a se autorizar como homem ou mulher, a lacuna antagônica do inconsciente perturba.

Mas no espaço de representação, estaríamos no jogo dos semblantes, na teoria lacaniana, e no da performance, de Butler. Em certa medida, o semblante seria parente próximo da performance de gênero. Antes de avançarmos às ideias butlerianas, tratemos do trabalho de Gayle Rubin, de 1975 - decisivo para os gender studies - e da maneira com que o lacanismo foi recepcionado em solo norte-americano.

\subsection{Rubin e o sistema sexo/gênero}

O movimento da escrita feminina dos anos 70, contemporâneo às reivindicações das mulheres quanto ao direito de decidir sobre o seu corpo na esfera política, propunha inscrever o corpo da mulher no discurso e fundar a escrita de suas especificidades. Freud é, mais uma vez, questionado. A crítica ao falo é reincendiada sob os termos falocratismo e falogocentrismo, com a vestimenta do lacanismo e das ideias de Derrida. Inspirada em Jones, retorna a discussão a respeito de uma libido feminina, ou mesmo um inconsciente feminino. Feminismo e psicanálise estiveram intricados nos primórdios da psicanálise e não seria diferente daqui para frente. Cruzando o Atlântico, o feminismo teve papel decisivo para a implantação e a propagação da teoria psicanalítica em solo norte-americano.

A batalha entre a psicanálise e os movimentos gay e das mulheres se tornou legendário. Em parte, esse confronto entre revolucionários sexuais e clínica "estabelecida" tem sido motor da evolução da psicanálise nos Estados Unidos, onde esta tradição clínica fetichizou a anatomia. (ROUDINESCO, 1994, p. 184) 
Se, em campo francófono, um "lacanismo linguageiro" foi privilegiado, naquele país foi a retomada de Lévi-Strauss da antropologia estrutural empregada por Lacan que foi evidenciada. O trabalho de Gayle Rubin de 1975 foi fundamental nesse processo. Segundo a antropóloga, a circulação do falo não seria mais do que uma versão refinada da troca de mulheres, levando sempre ao mesmo ponto: opressão e hierarquização dos gêneros e das práticas sexuais não heterossexuais.

De onde vem a origem da opressão e da subordinação social da mulher? A resposta, complexa, está na base do feminismo e o modo como é estabelecida acaba determinando os meios pelos quais tal cenário poderia mudar em direção a uma sociedade sem hierarquia de gênero. Nosso foco aqui não é tentar dar conta desse problema na totalidade em que foi tratado pelos estudos de gêneros norte-americanos, talvez onde esse tema foi e continua sendo mais extensivamente abordado no mundo a quantidade de trabalhos, publicações, congressos, departamentos de universidades específicos é enorme - , mas analisar como o campo lacaniano foi recebido por elas. $\mathrm{Na}$ coleta dos textos fundamentais sobre o assunto, esse de Rubin, leitora de Lacan, é essencial para qualquer estudo sobre o feminismo que se queira em debate com a psicanálise.

É nesse trabalho, inclusive, que Rubin funda o sistema sexo/gênero, tão caro a Butler e à teoria queer.

Fome é fome, mas o que conta como comida é culturalmente determinado e adquirido [...]. Sexo é sexo, mas o que conta como sexo é, da mesma forma, culturalmente determinado e adquirido. Cada sociedade tem seu sistema sexo/gênero - um conjunto de arranjos pelo qual a matéria biológica do sexo humano e a procriação são moldadas pelo (como) humano, pela intervenção social e satisfeitas de modo tal como dita a convenção, sem importar o quão bizarra essa convecção possa ser. (RUBIN, 1975, p. 165; trad. nossa)

Embrião do quarteto butleriano, sexo-gênero-desejo-práticas sexuais, "sexo, tal como concebemos - identidade de gênero, desejo sexual e fantasia, concepções sobre o infantil — é um produto social" (RUBIN, 1975, p. 166). Essa é a chave de leitura de Rubin: os sistemas de parentesco são passíveis de serem analisados à luz desse sistema de sexo/gênero.

Rubin apresenta diversos relatos antropológicos como forma de demonstrar como diferentes culturas, em diferentes momentos históricos, entendem o sexo e como sua interpretação determina os lugares sociais do homem e da mulher. E que só sob 
certas condições históricas uma mulher é e faz o que caberia a uma mulher, ou seja, é o cenário social que oferece os critérios pelos quais se avaliará se um ser corresponde adequadamente a uma mulher (ou a um homem).

O sistema sexo/gênero não serve somente para se pensar tais questões na contemporaneidade, já que, por exemplo, o sexismo já estava presente em sociedades pré-capitalistas, haja vista a prática do cinto de castidade na Europa feudal. Rubin também se esforça em demonstrar que as forças econômicas não são a única engrenagem desse sistema sexual. Ele não deve ser tratado como sinônimo de "patriarcado", já que este se refere a uma forma específica de dominação masculina — existem sistemas estratificados a partir do gênero que foram organizados de outra forma, tal como se detecta em sociedades da Nova Guiné, nas quais o poder do homem não deriva do seu papel de pai, mas de certos rituais de iniciação ou cultos nos quais tal poder é incorporado. Então sexo/gênero não é sinônimo de patriarcado, não deve ser reduzido à economia e pode ser um instrumento de análise de como as relações de parentesco de várias culturas, em diferentes momentos históricos se deram.

E por que recorrer à psicanálise? Por esta poder dar conta do que a antropologia não se propõe a tratar, ou seja, como o parentesco se reproduz, como as convenções de sexo e gênero são internalizados pelos sujeitos; e, sobretudo, por se dedicar ao resíduo, ao que sobra da não adequação do sujeito às regulações da sexualidade ditadas pela sociedade (RUBIN, 1975, p. 183).

Sobre os psicanalistas, "o trabalho deles nos habilita a isolar sexo e gênero dos modos de produção, opor-se a uma tendência a explicar a opressão sexual como reflexo somente das forças econômicas" (RUBIN, 1975, p. 203). Fatores históricos, políticos, tecnológicos, econômicos devem ser levados em conta, mas também as novidades trazidas pela psicanálise. Ao contrário de Marx, que trataria do trabalhador e do capitalista como seres assexuados, tanto Freud quanto Lévi-Strauss têm o mérito de reconhecer e incorporar em suas teses as diferenças pelas quais homens e mulheres atravessam. Contudo, para Rubin, Freud e Lévi-Strauss padeceriam de ingenuidade: eles não calcularam as implicações que seus aportes teóricos poderiam ter para o feminismo, não levaram em conta o sexismo endêmico que descreviam, desconsiderando a história. Para ela, é só através da análise do elemento histórico e moral, incluindo nesse escopo a diferença sexual, que se pode delinear como a opressão sexual se estruturou - o que a psicanálise não teria considerado. 
Mesmo Estruturas elementares de parentesco tendo valor por “desbiologizar" a determinação dos papéis sociais e ligá-los ao terreno do sexual, ainda assim daria força ao mecanismo segregador do gênero:

é uma obra no qual o parentesco é explicitamente concebido como uma imposição da organização cultural sobre as evidências da procriação biológica. É permeado pela consciência da importância da sexualidade na sociedade humana. É uma descrição da sociedade que não toma o sujeito humano como abstrato, sem gênero. Pelo contrário, o sujeito humano no trabalho de Lévi-Strauss é sempre homem ou mulher, e os destinos sociais divergentes dos dois sexos podem, portanto ser traçados. Como Lévi-Strauss vê que a essência do sistema de parentesco se baseia na troca de mulheres entre os homens, ele constrói uma teoria implícita da opressão ligada ao sexo. (RUBIN, 1975, p. 171; trad. nossa)

A troca de mulheres, realizada por homens, é o que promove a conexão entre diferentes comunidades, o que pressupõe uma determinada relação de parentesco na qual o incesto é tido como tabu. Importante enxergar que, nesse sistema descrito por Strauss, a opressão à mulher — fruto de um arranjo social não determinado biologicamente - não seria restrita ao mundo primitivo, estendendo-se ao mundo civilizado, no qual a mulher ainda clama por direitos. Outro problema levantado por Rubin (1975, p. 176) é que "Lévi-Strauss argumenta que o tabu do incesto e os resultados de sua implicação constituem a origem da cultura, como se a anulação da mulher fosse um pré-requisito para a fundação da cultura". Ela defende que nem a troca de mulheres descreve ou sustenta tudo o que pode se dar num sistema de parentesco, nem toda ordem cultural nasceria dessa prática social. Além do mais, cada sociedade determina o mecanismo pelo qual as convenções referentes à sexualidade são configuradas.

Rubin, a respeito do ensaio La famille, também de Lévi-Strauss, aponta que a divisão de trabalho entre homem e mulher é vista como tabu ao preconizar duas categorias exclusivistas, que "exacerba as diferenças biológicas entre os sexos e desse modo cria o gênero" (RUBIN, 1975, p. 178). Nesse sentido, o arranjo sexual privilegiado é o casamento heterossexual, um homem e uma mulher, tido como a unidade econômica viável. Na nossa cultura, a lógica estrutural que subjaz o parentesco toma como ponto de partida a heterossexualidade obrigatória, a partir da qual o casamento entre homem e mulher é a relação de parentesco válida, a homossexualidade deve ser banida e a sexualidade feminina, desconsiderada. O gênero acaba sendo 
imposto a partir da divisão sexual e o sistema de parentesco transforma o macho e a fêmea em homem e mulher.

Para que este quadro se imponha, há de se potencializar a diferença entre os sexos. Rubin não nega que elas existam, "mas (homens e mulheres) não são tão diferentes como dia e noite, terra e céu, yin and yang, morte e vida" (RUBIN, 1975, p. 179). Na natureza, o homem é menos diferente da mulher do que o é com relação a uma árvore ou a um peixe, o que faz pensar que não é tanto a natureza que impõe essa ideia de que homem e mulher sejam elementos radicalmente opostos. "Longe de ser a expressão de diferenças naturais, a identidade exclusiva de gênero é a supressão das similaridades naturais" (RUBIN, 1975, p. 180), Nesse sentido, o entendimento de 'homem' parte da repressão dos traços que apontem para o feminino, e o mesmo para o de 'mulher', com relação ao masculino. Gênero acaba sendo a identificação com um só sexo e toda união não heterossexual é tabu.

A supressão do componente homossexual da sexualidade humana é fruto do mesmo sistema que impõe as regras que oprimem a mulher, segundo Rubin (1975, p. 180). A psicanálise, nos seus desenvolvimentos teóricos referentes ao Édipo e à constituição da identidade sexual - tal como concebe as figuras parentais, seus papéis e relações —, seria herdeira de todo esse arcabouço levistraussiano, contribuindo cegamente para a opressão e hierarquização impostas pelo patriarcado ao feminino, assim como exilando as práticas não heterossexuais.

Rubin destaca que nos EUA, pelo menos num primeiro momento, a clínica psicanalítica foi encarada como provedora duma técnica que prometia fazer com que o indivíduo avançasse as fases desenvolvimentistas sexuais em direção ao que lhe estava anatomicamente determinado, ou seja, em direção à heterossexualidade - ela ofereceria uma terapêutica aos sujeitos que não corresponderiam ao ideal genital, para reparar o erro: "a psicanálise se tornou mais do que uma teoria dos mecanismos de reprodução dos arranjos sexuais, ela é um desses mecanismos” (RUBIN, 1975, p. 184).

Por outro lado, Rubin reconhece que a teoria psicanalítica apresenta pontos positivos e úteis ao feminismo, principalmente ao descrever os mecanismos pelos quais os sexos são divididos e diferenciados a partir da bissexualidade original. Nesse sentido, "a psicanálise é uma teoria feminista manqué" (RUBIN, 1975, p. 185). Rubin também vê com simpatia os desenvolvimentos teóricos referentes ao estágio pré-edípico, cujas características (bissexualidade, pulsão parcial) podem reformular ideias referentes à heterossexualidade primordial e à identidade de gênero. Apesar das implicações de 
temas - como inveja do pênis, libido masculina, inferioridade da mulher na comparação ao homem - que tanto enfureceram as feministas, Rubin considera que o fato de o postulado freudiano do percurso da mulher em direção à feminilidade não ser biologicamente determinado deve ser visto com entusiasmo.

Contudo, ela não é tão benevolente com o lacanismo. "Lacan sugere que a psicanálise é o estudo dos traços deixados no psiquismo dos indivíduos como resultado da conscrição ao sistema de parentesco" (RUBIN, 1975, p. 188) — por aí já vemos a lente pela qual Rubin lê Lacan.

No esquema de Lacan, a crise edípica ocorre quando a criança aprende as regras sexuais decretadas nos termos da família e de seus parentes. A crise começa quando a criança compreende o sistema e o seu lugar nele; a crise é dissipada quando a criança aceita aquele lugar e acede a ele. (RUBIN, p. 189; trad. nossa)

Nesse contexto, esse sistema inibe a expressão de toda diversidade e de todas as possibilidades abertas na fase pré-edípica da criança: algumas são encorajadas, outras devem ser reprimidas de acordo com as regras culturais - edípicas, no caso em jogo.

Rubin reconhece que, em Lacan, falo não é sinônimo de pênis e que a castração tem sua vertente simbólica. Mesmo assim,

[...] o falo carrega o significado do domínio do homem sobre a mulher, e pode ser inferido que a "inveja do pênis" é o reconhecimento disso. Além disso, na medida em que os homens têm direitos sobre as mulheres que elas próprias não têm sobre si mesmas, o falo também traz em si o significado da diferença entre "trocador" e "troca(da)", quem é fornecido e quem fornece. (RUBIN, 1975, p. 191; trad. nossa)

O falo seria, na ótica de Rubin, um objeto simbólico a ser trocado entre as famílias: "em certo sentido, o complexo de Édipo é um expressão da circulação do falo nas trocas dentro das famílias, uma inversão da circulação de mulheres nas trocas entre famílias" (RUBIN, 1975, pp. 191-2). O falo, além de entrar em jogo na diferença dos sexos, incorpora o status masculino de ter direitos sobre as mulheres: se as mulheres são elementos que passam de um homem a outro, também nas trocas simbólicas nas quais o falo está presente, elas não têm participação senão a partir do que o homem lhes permite, problematizando a tese lacaniana de "ter ou não ter" o falo. 
[...] é somente através dele que ela pode entrar no sistema de troca simbólica na qual o falo circula. Mas o pai não dá a ela o falo da mesma forma que ele o dá ao menino. O falo é afirmado no menino, que depois tem de concedê-lo. A menina nunca consegue o falo. Ele passa através dela, e nessa passagem [o falo] é transformado em um filho. Quando ela 'reconhece sua castração', ela acessa o lugar de uma mulher na rede de troca fálica. Ela pode 'ter' o falo - no ato sexual, ou na forma de um filho - , mas só como um dom vindo do pai. Ela nunca o tem para poder concedê-lo. (RUBIN, 1975, p. 195; trad. nossa)

Ou seja, trocam-se os elementos e mantêm-se os princípios concebidos por Lévi-Strauss para se pensar o sistema sexo/gênero tal como se manifesta hoje em dia? É como se estivéssemos acompanhando o renovar da "expressão da transmissão da dominação masculina" (RUBIN, 1975, p. 192). Se a organização do sexo e do gênero tem implicações para além do campo da sexualidade, chegando ao extremo de organizar a própria sociedade, segundo Rubin, "o feminismo deve clamar por uma revolução no parentesco" (RUBIN, 1975, p. 199) para alcançar seus objetivos.

Contudo, Lacan apresenta esta passagem a respeito do patriarcado, anunciando que, para ele, o Édipo deve ser tratado pela lógica e pela noção de número, percurso esse que será trilhado por nós mais adiante:

O mito do Édipo faz espalhafato porque, supostamente, instaura a primazia do pai, que seria uma espécie de reflexo patriarcal. Eu gostaria de fazê-los perceber por que, pelo menos para mim, ele de modo algum parece ser um reflexo patriarcal, longe disso. Ele nos evidencia por onde a castração poderia ser tomada por uma abordagem lógica, e de um modo como eu designaria numeral. (LACAN, 1971-72/2012, p. 162)

Voltando a Rubin. Ela já havia preconizado que a estratégia feminista não deve ser a de eliminar os homens; não se trata de inverter os papéis para que as mulheres assumam o poder, já que tal estratégia alimentaria o sistema que cria sexismo e hierarquia de gênero, tal como as feministas francesas também pensavam.

$\mathrm{Eu}$ pessoalmente acho que o movimento feminista deve sonhar com mais do que eliminar a opressão das mulheres. Deve sonhar com a eliminação das sexualidades obrigatórias e dos papéis sexuais. O sonho que considero mais instigante é o de uma sociedade andrógena e sem gênero (mas não sem sexo), na qual o sexo anatômico seja irrelevante para quem se é, o que se faz ou com quem se faz amor. (RUBIN, 1975, p. 204; trad. nossa) 
O sexo deve ser desvinculado da anatomia, o que não quer dizer que a salvação seria nos atermos ao "gênero". Para Rubin, esse termo traria em si, assim como considera Wittig, a marca da opressão. A estratégia seria, mais uma vez, eliminá-lo? Eliminá-lo como substância não é sinônimo de eliminá-lo como categoria. Butler vê uma alternativa intermediária e trata de gênero como entidade performativa sem essência, ou como elemento que só adquire aparência de essência enquanto performatizado.

Tratemos então de Butler. Crucial apontar que não pretendemos dar conta de toda a teoria de Butler sobre gênero, sobre a constituição de sujeito, ou da sua intricada formulação do sujeito melancólico. O que nos interessa é sua apropriação dos conceitos da psicanálise lacaniana e o modo afiado com que os interpretou. Butler tem o mérito de oferecer uma leitura aguçada sobre pontos problemáticos da psicanálise, como o estatuto do registro simbólico e da diferença sexual, as posições de ser e ter o falo, que não à toa suscitou uma quantidade enorme de trabalhos em resposta às críticas que endereçou à psicanálise. Por isso, todo o espaço dedicado a ela e a seus comentadores. O debate que incita é extremamente útil, pois obriga os psicanalistas a enfim tratarem de fundamentos obtusos da psicanálise que costumam passar incólumes, em boa parte, nas suas instituições de transmissão.

\subsection{Butler e a problemática lacaniana}

“E o que acontece à tarefa teórica do feminismo de pensar a transformação social se nós aceitarmos que a diferença sexual está orquestrada e constrangida ao nível simbólico? Se for simbólico, é mutável? Eu faço essa pergunta aos lacanianos e eles, usualmente, me dizem que as mudanças no simbólico tomam um tempo muito, muito longo. Eu imagino quanto tempo terei de esperar."

— Judith Butler (2004, p. 212; trad. nossa)

Judith Butler é uma filósofa marcada notadamente por autores pósestruturalistas, como Foucault, Deleuze, Derrida, e por teses da filosofia crítica alemã pós-kantiana e hegeliana. Trata-se de uma expoente da teoria queer que também recorre ao french feminism de Irigaray, Wittig e Kristeva, ao passo que mantém um diálogo tenso e constante com Freud e Lacan. 
Suas apreciações a respeito da tese lacaniana da "lei do pai" constam desde seu primeiro livro, Subjects of desire (1987), e percorrem toda a sua obra, sempre sendo incrementadas, complexificadas e expandidas para diferentes contextos, desde a identidade de gênero e as condições da constituição do sujeito até as relações de parentesco e os cenários políticos atuais. Butler ilumina pontos duvidosos da teoria lacaniana, como os desdobramentos referentes ao ser e ter o falo, no que compete a mulher e homem, e a enigmática expressão "assumir o tipo do ideal de sexo", proclamada por Lacan mais de uma vez nos anos 50 .

Butler empenha-se insistentemente em questionar as condições e os processos a partir dos quais o sujeito existe, quais os fundamentos que determinam a legitimação dos gêneros, dos corpos e dos arranjos sociais, sempre guiada pelo projeto de desestabilizar categorizações fixas e naturalizadas de sexo e gênero, perseguindo o caráter contingencial e instável do sujeito e do social. Só dessa forma seriam abaladas as normas instituídas a partir da monogamia heterossexual e genital, compulsória e universal. Ao desconstruir e desfazer a essência intuitiva de identidade que percorre os gêneros, o imprevisível viria à tona, reconfigurando o que se entende por humano e suas possibilidades de reconhecimento.

Em suas construções teóricas, Butler costuma incorporar noções psicanalíticas em seu proveito, como se dá com pulsão e foraclusão. Até certo ponto "somos dirigidos por aquilo que não conhecemos e não podemos conhecer. Esta 'pulsão' (Trieb) é precisamente o que não se reduz à biologia e nem à cultura, mas sempre o lugar de sua densa convergência” (BUTLER, 2004, p. 15). O corpo pulsional não se verte completamente às normas que coagem sua materialização em corposhomem e corpos-mulher, uma das teses de Bodies that matter. A 'pulsão' traz em si tanto uma potência para a transformação quanto para a resistência, o que faz dela uma noção útil aos propósitos políticos butlerianos. O mesmo se dá com a 'foraclusão' lacaniana, mecanismo psíquico cujo funcionamento estaria na base da constituição do sujeito melancólico e dos processos de abjeção social. 'Gênero', tal como teorizado pela filósofa, também pode ser pensando ao lado do 'semblante' lacaniano, das noções de 'mascarada' e 'parada viril' desenvolvidas no Seminário XVIII.

Por outro lado, seguindo a tradição feminista norte-americana que se voltou para Lacan, Butler problematiza insistentemente alguns de seus conceitos, principalmente o de "Simbólico", instituído a partir do estruturalismo de Saussure e Lévi-Strauss, e interpretado por ela como totalitário, dualista, inflexível e mantenedor 
do universalismo masculino e da norma heterossexual. Este parece ser seu principal ponto de crítica à psicanálise lacaniana: o que é estruturado pela ordem simbólica é passível de transformação? Passemos aos desdobramentos de Butler inspirada em Rubin $^{24}$, ao tratar do simbólico lacaniano herdeiro da antropologia estrutural.

\subsubsection{Simbólico, lei e relações de parentesco}

Em Antigone's claim (2000), Butler desenvolve sua leitura da Antígona de Sófocles estabelecendo um debate acerca das análises de Hegel e Lacan sobre tal tragédia grega.

$\mathrm{Na}$ trama, Antígona era filha da união incestuosa estabelecida entre Jocasta e Édipo, até então rei de Tebas, tendo Polinice, Etéocles e Ismena como irmãos. Após Édipo dirigir-se ao deserto, Creonte, seu irmão e tio, assume o reinado. Enquanto Etéocles apoia o ato de posse de Creonte, Polinice se põe contra ele. Consequentemente, os dois irmãos travam uma batalha que resulta na morte de ambos nas cercanias de Tebas. Creonte autoriza que somente Eteócles seja enterrado com todas as honras:

Polinice sofrerá o pior dos destinos que um homem grego pode enfrentar. Não apenas será esquecido, Polinice não será rememorado, e assim é como se nunca tivesse existido. Os ritos fúnebres marcam a integração de alguém à comunidade simbólica grega. Sua ausência torna-se, assim, o mesmo que uma exclusão simbólica. (DUNKER, 2011, p. 116)

O crime de Antígona foi enterrar seu irmão, indo contra a determinação de Creonte. Denunciada pelos guardas, Antígona não desmente seu ato; pelo contrário, recusa-se a negá-lo e verbalmente assume sua autoria perante o público.

Para Hegel, Antígona representa o parentesco e sua dissolução, ao passo que Creonte representa a ordem ética e a autoridade do Estado baseado nos princípios da universalidade - o parentesco se subordina ao Estado, mesmo sendo esse dependente das relações de parentesco para sua manutenção. Lacan também operaria dicotomicamente: o parentesco é dissociado da esfera do social. Para Butler, nem um

\footnotetext{
${ }^{24}$ Butler, em entrevista com Rubin realizada em agosto de 1994, diz a ela: "E o que me interessou em "The traffic in Women" foi que você, usando um termo que provém do discurso sociológico americano — "gênero" - , na verdade o gênero menos fixo, imaginou uma espécie de mobilidade que suponho ser absolutamente impossível num contexto lacaniano. Assim, acho que você produziu uma mescla de posições que muito me agradou e se tornou um dos motivos pelos quais abordei também a questão de gênero e desenvolvi o meu Gender trouble" (Tráfico sexual - entrevista. Cadernos Pagu (21) 2003, p. 164. Recuperado em: 〈http://www.scielo.br/pdf/cpa/n21/n21a08.pdf >).
} 
nem outro: Antígona permite pensar a "noção de parentesco aprisionada estruturalmente nos termos de sua iterabilidade social, a aberrante temporalidade da norma" (BUTLER, 2000, p. 29).

Segundo Butler, Lacan está demasiadamente marcado por Lévi-Strauss, para quem a esfera social emerge da estrutura de comunicação e legitimidade fundamentada por normas linguísticas inflexíveis, denominada ordem simbólica. $\mathrm{Na}$ leitura butleriana de Estruturas elementares de parentesco, Lévi-Strauss relaciona a troca de mulheres com a troca de palavras. Esse circuito de palavras se torna a base para se pensar as relações de parentesco, não mais estabelecidas nos termos de relações consanguíneas ou arranjos sociais naturalizados, mas sim a partir da linguagem.

Dessa forma, a ordem simbólica institui uma estrutura de parentesco não maleável, congelando seus arranjos sociais. Suas relações são sustentadas por leis e proibições - no nosso caso, a proibição do incesto. As regras erigidas a partir do tabu do incesto são alçadas ao status de condição universal, impondo normas e moldando tipos de vínculos a serem legitimados ou não: "o simbólico é o que impõe limites a qualquer esforço utópico de reconfigurar e revitalizar as relações de parentesco que se distanciem da cena edípica" (BUTLER, 2000, p. 20).

No contexto das relações de parentesco, Butler sustenta a concepção de que a psicanálise só produz conformidade, impossibilitada que está de promover levantes contra a disciplinarização imposta pela heteronormatividade. Na leitura de Butler, o simbólico lacaniano é uma estrutura monolítica inalterável por contingências internas ou externas ao sujeito.

O simbólico é o "domínio da lei que regula o desejo no complexo de Édipo" (BUTLER, 2000, p. 18). A entrada no complexo de Édipo tem como condição a proibição do incesto, estabelecendo posições dentro da família alicerçadas em um mandato exogâmico. Contudo, Butler questiona se existiria um tipo de vida social que acomodaria mudanças nas relações de parentesco. Para a filósofa, Antígona apontaria justamente para esse lado. Dentro do contexto edípico, seu desejo só poderia conduzi-la à morte, já que desafiava as normas simbólicas - como se seu desejo tivesse revelado o que o simbólico não suportava (BUTLER, 2000, p. 29).

Antígona não representa os princípios normativos de parentesco por, desde sua origem, estar mergulhada em um legado incestuoso (filha da relação incestuosa Édipo/Jocasta; Édipo é, ao mesmo tempo seu pai e irmão, sendo ambos filhos de Jocasta; é devotada a certo tipo de relação amorosa com seu irmão). Em seus atos - 
tanto no de desafiar a lei, ao enterrar o irmão, quanto no de confessá-lo verbalmente Antígona é vista como masculinizada, indo contra as normas que determinam as relações e os papéis de gênero.

Antígona fala a "língua da lei" em seu desafio de ir contra a lei, ela incorpora o Estado nesse processo de se voltar contra ele. Contudo, a lei de Antígona não é escrita, não tem origem localizável. Que tipo de lei é essa? A lei de Antígona é descrita por Hegel como uma lei feminina, fora do campo político do direito público. Em seu ato, Antígona defende seu irmão sustentando uma lei que parece só se focar em uma instância de aplicação: seu irmão é único, assim como deveria ser a lei aplicada nesse caso, ou seja, sem reprodutibilidade ou transponibilidade possíveis - tratar-se-ia de uma lei focada no singular, ou de uma lei singular. Seu ato transgride as proibições normativas do parentesco, assim como expõe sua vulnerabilidade.

Nas palavras de Rodrigues:

$\mathrm{Na}$ estrutura de parentesco, o tabu do incesto organiza o jogo, que só se dá a partir da manutenção de uma diferença sexual que é binária, opositiva e responde à lei do Pai. Antígona seria, para Butler, o que aponta as singularidades da lei. À diferença do que quis Hegel - que viu na personagem trágica a passagem do campo particular do parentesco para o campo universal do Estado - e à diferença do que pensou Lacan - que viu a morte de Antígona como resultado de sua permanência em uma singularidade que recusa a ordem do simbólico - Antígona seria aquela cuja reivindicação se dá em nome de uma lei do singular, lei que não se estabelece a partir do fundamento, mas do reconhecimento do abismo do fundamento, lei que aponta o caráter abismal do fundamento da lei universal. (RODRIGUES, 2012, p. 50)

Para Butler, não se trata — como teriam pensado Lacan e Hegel — de uma figura apolítica, que representava o parentesco cuja esfera fornecia "as condições de possibilidade para a política sem, contudo, fazer parte dela" (BUTLER, 2000, p. 2). Pelo contrário, seu ato é político também por expor o caráter contingencial implicado nas determinações do parentesco, apontando seus limites. Por fim, Butler declara que Antígona, aos se situar fora do simbólico, associa-se à morte:

[...] uma das razões pelas quais ficar do lado do irmão a implica em uma morte em vida é que, assim, revogam-se precisamente as relações de parentesco que o simbólico lacaniano articula, as condições de inteligibilidade da vida. Ela não simplesmente entra na morte por abandonar os laços simbólicos da comunidade para recuperar uma impossível e pura ontologia do irmão. O que Lacan omite nesse momento, manifestando sua cegueira, talvez, é que ela sofre de uma 
condenação fatal graças à virtude de rescindir o tabu do incesto que articula parentesco e simbólico. Não é que a pura essência do irmão seja irrecuperável das antecâmaras das articulações simbólicas, mas que o próprio simbólico seja limitado pelas suas interdições constitutivas. (BUTLER, 2000, p. 53; trad. nossa)

Butler segue questionando: "Quais as consequências de se considerar certos tipos de parentesco atemporais e elevá-los ao status de estruturas elementares de legitimidade?" (BUTLER, 2000, p. 20). Por mais que normas sociais não sejam sinônimas de posição simbólica, a psicanálise se fundamentaria numa lei simbólica que põe limites ao social, decretando as relações de parentesco a serem legitimadas. Nesse sentido, o que escapa da lei simbólica e das relações de parentesco edipianas estabelecidas por ela é relegado ao limbo do inumano. A forma de combater tal cenário, Butler adverte, não seria abolir o tabu do incesto como estratégia para que o amor livre ou as relações incestuosas sejam disseminados (BUTLER, 2000, p. 24). Não é disso que se trata, mas sim de se discutir sobre o que faz com que certas relações de parentesco, certos arranjos ou práticas amorosas sejam validados e outros não; quais formas de sofrer podem ser reconhecidas e quais não: Antígona nega submeter-se a uma lei que recusa reconhecer seu sofrimento como fruto de uma perda legítima.

Mesmo a psicanálise tendo insistido que o processo de normatização é necessariamente disruptivo e contrariado por aquilo que não se curva às normas, pouco se questiona sobre como novas formas de parentesco podem surgir. Considerando que o tabu do incesto é mobilizado para estabilizar e legitimar outras formas de parentesco (BUTLER, 2000, p. 66), quais formas particulares seriam possíveis? E se a tragédia eleita como sustentáculo da psicanálise fosse Antígona, e não Édipo-Rei? - questiona Butler. Outras formas de parentesco e família seriam aceitas e despatologizadas? A heterossexualidade normativa seria desestabilizada?

Para Butler, a distinção entre a ordem simbólica e a esfera social não faz sentido, tal como o ato de Antígona aponta. Não porque o simbólico também possa ser concebido como uma sedimentação de práticas sociais, mas porque alterações nas relações de parentesco tradicionais - tal como a união de homossexuais; novas formas de famílias, nas quais filhos são adotados por mães solteiras, dentre outras rearticulariam pressuposições psicanalíticas estruturalistas que sustentam a ordem simbólica (BUTLER, 2000, p. 19). "Insistir que parentesco é estabelecido através de recursos linguísticos e simbólicos que são enfaticamente não sociais é, penso eu, perder de vista que parentesco é uma prática social contingente” (BUTLER, 2004, p. 157-8). 
As práticas sociais são contingentes, mas o simbólico também? Charles Shepherdson, autor de Vital signs (2000), obra dedicada quase que exclusivamente ao exame da interpretação do registro simbólico lacaniano por teóricas feministas, oferece alternativas a leituras como a de Butler. O simbólico lacaniano, segundo Shepherdson (2000, p. 88), não diz respeito às convenções historicamente produzidas pelas diversas culturas - entendimento esse do simbólico comum em cultural studies.

O simbólico em Lacan não seria o equivalente de qualquer forma de organização particular — o patriarcado, por exemplo, seria a forma com que cultura ocidental contemporânea elegeu como sistema social predominante, não que o registro simbólico por conta própria o tenha imposto. Por outro lado, o simbólico, se não é possível de ser transformado por eventos sociais, isto não quer dizer que ele seja ahistórico - pelo contrário, é esse registro o que permite que a experiência humana entre na dimensão do tempo e possa ser historicizada: "de fato, não se trata da questão de 'retorno à história', contra a noção de simbólico, já que é a inevitabilidade do simbólico que faz a história não só possível, mas inescapável, para o animal humano" (SHEPHERDSON, 2000, p. 35). Nesse sentido, o simbólico, em si, não é reestruturável, mas sim as organizações socioculturais criadas a partir dele; não é o simbólico que impede que novas relações de parentesco surjam, mas justamente o que fornece as condições estruturais para que quaisquer relações de parentesco sejam criadas. Assim, seria um equívoco tomar o tabu do incesto, um decreto de ordem cultural ou antropológica, como determinante para o simbólico. O simbólico não seria, na visão de Shepherdson, edificado a partir da heterossexualidade nem prescreve quais práticas sexuais devem ser aceitas e quais devem ser excluídas — o simbólico lacaniano não imputaria regras de inteligibilidade cultural.

Contudo, esse aspecto negativo e esvaziado atribuído ao simbólico traria problemas para o projeto político feminista, justamente por não dar margem a mudanças sociais.

Rubin confessa em entrevista a Butler, quando da escrita de "Traffic in women": "A psicanálise lacaniana é muito útil para lidar com estruturas de gênero e desejo, mas tem seu preço. Eu me preocupava com as tendências totalizantes em Lacan, e com o caráter não social de sua concepção do simbólico”. E essa última, em outro momento da entrevista, acrescenta: "Mas acho que essa é uma das razões pelas quais o social não tem grande expressão e, na verdade, não tem interesse para muitos dos que trabalham no domínio lacaniano" (RUBIN, 2003, pp. 165-6). 
Butler critica essa concepção psicanalítica da linguagem que se associa à transcendência e à imutabilidade das convenções. Para ela, as normas que operam como fenômenos psíquicos também circunscrevem o domínio do social. Indo além, "as categorizações sociais que estabilizam a vulnerabilidade do sujeito à linguagem são, elas próprias, vulneráveis tanto a mudanças psíquicas quanto sociais” (BUTLER, 1997, p. 21). Butler vai contra a visão de que a normatividade psíquica ou linguística, versões do registro simbólico, sejam anteriores, condicionantes ou mesmo delimitadoras do campo social: tanto o sujeito deriva de condições de poder que o precedem quanto as normas de operação psíquica provêm de operações sociais. Interpretar a lei simbólica como radicalmente afastada da norma social - cujo caráter é histórico, mutável e combatível — implica alimentar a concepção de que a lei, por outro lado, seja inabalável pelo social, o que vai totalmente contra os propósitos butlerianos.

A filósofa argumenta que os vínculos amorosos da criança a subordina a inescapáveis regulações normativas. Seus primeiros objetos (pais, parentes e cuidadores), nos quais seu amor é investido, são aqueles dos quais ela é dependente física e emocionalmente para sobreviver. Tal relação de dependência, no fundo, é uma relação de poder. Não precisamos ir muito longe para deduzirmos que é tendo isso como pano de fundo que Butler interpreta o complexo de Édipo no contexto da constituição do sujeito em psicanálise. O Édipo, para ela, é um processo de assujeitamento à lei do Pai, equiparada à ordem simbólica.

Ellie Ragland-Sullivan, cujos trabalhos sobre a teoria lacaniana são referência nos Estados Unidos, posiciona-se frente a essa interpretação de lei. A autora parte da consideração de que o Outro, entendido como o campo da linguagem, precede e concorre para o surgimento do sujeito, sendo a submissão à lei simbólica o que dá as bases de sua constituição e o acesso ao espectro do desejo. Nesse sentido, RaglandSullivan (2004) considera que, se há uma política interna ao falo, ela não diz respeito a leis sociais ou a quaisquer entidades sociológicas, mas a uma política do desejo que desvia o sujeito do campo da necessidade. Se Butler vê a lei como um instrumento de submissão, sob a ótica das relações de poder, Ragland-Sullivan considera que a lei simbólica é contemporânea da constituição do sujeito enquanto ser de linguagem, processo esse que o torna um ser desejante.

\subsubsection{Gênero e norma simbólica}


Para Butler, a noção de gênero é fundamentalmente política e só pode ser pensada a partir do aporte performativo da linguagem que deriva de Austin. A teoria da filósofa norte-americana busca investigar o gênero a partir de manifestações da sexualidade que fogem à norma, como a transexualidade e o travestismo, tal como procedeu Stoller.

Em Problemas de gênero (1990/2003), Butler revela que a norma heterossexual vigente se sustenta em uma concepção binária dos sexos e dos gêneros. A heterossexualidade compulsória exige, ainda, que caracteres sexuais anatômicofisiológicos, gênero, desejos e práticas sexuais estejam em concordância — por exemplo: corpo biologicamente homem, gênero masculino, desejo por mulheres, prática heterossexual. Os sujeitos que fogem a esse sistema ideal de coerência e continuidade não se adequam aos gêneros inteligíveis, masculino e feminino, sendo, consequentemente, relegados à invisibilidade e à patologia. Butler os denomina "seres abjetos", importando o termo de Kristeva. Estão fora do cenário social; ao mesmo tempo, garantem sua consistência. É a tais sujeitos que Butler quer dar voz como forma de denunciar que a dimensão de sofrimento e discriminação de que padecem é efeito de mecanismos histórico-sociais que visam normatizar os gêneros e a regular a produção do humano. $\mathrm{O}$ modelo butleriano também salienta que a exigência de adequação a matrizes de identidade fixa também é fonte de patologia - o que permite, então, considerar uma política pós-identitária.

Partindo do sistema descrito por Rubin, Butler mostra que, além de gênero não ter essência identitária - e também não ser fruto de meras construções sociais -, a combinatória sexo/gênero se sustenta em uma unidade ilusória. Para tanto, ela define gênero como ato performativo. Palavras, gestos e atos expressos reiteradamente criam a realidade dos gêneros e a ilusão de substância, naturalidade e a-historicidade que costumamos atribuir a eles, sempre coordenados por uma estratégia de poder que visa manter o gênero em sua estrutura binária e a ocultar seu caráter intencional e performativo. Contudo, trata-se de citações, reiterações e paródias encenadas a partir de convenções - que, por sua vez, são edificadas a partir da ilusão de um modelo original. Não há "agente" por trás do ato, não há estrutura pré-discursiva. O agente é construído a partir do ato. É como se gênero, em si, não existisse; o que existe é a paródia de gênero.

Freud já demonstrara que sexo e identidade sexual não são necessariamente elementos correspondentes, anunciando indícios teóricos que apontam para a descontinuidade entre sexo, gênero, desejo e práticas sexuais — tese salientada por 
Butler. Contudo, em Freud, a incongruência entre eles é sinal de patologia. Para Butler, a postura freudiana derivaria do modelo binário dos sexos, do qual ele parte, e que o leva a uma concepção de identidade sexual ontologizada, sustentada por uma teoria que prega uma origem naturalizada dos gêneros.

No pensamento freudiano, é a partir do Édipo que o sujeito se identifica como homem ou mulher; e a teoria lacaniana dos anos 50, numa certa leitura, corroboraria tal concepção: o complexo de castração promoveria "sua ratio, a instalação, no sujeito, de uma posição inconsciente sem a qual ele não poderia identificar-se com o tipo ideal de seu sexo" (LACAN, 1958/1998, p. 692). Esse é um ponto levantado por Butler (1993/2010) que nos parece fundamental discutir, também expresso na obscura asserção lacaniana sobre "a assunção do sexo", tal como aparece no Seminário V:

[...] o complexo de Édipo tem uma função normativa não simplesmente na estrutura moral do sujeito, nem em suas relações com a realidade, mas quanto à assunção de seu sexo - o que, como vocês sabem, sempre persiste, na análise, dentro de uma certa ambiguidade. [...] há no Édipo a assunção do próprio sexo do sujeito, isto é, para darmos os nomes às coisas, aquilo que faz com que o homem assuma o tipo viril e com que a mulher assuma um certo tipo feminino, se reconheça como mulher, identifique-se com suas funções de mulher. A virilidade e a feminilização são os dois termos que traduzem o que é, essencialmente, a função do Édipo. Encontramonos, aí, no nível em que o Édipo está diretamente ligado à função do Ideal do eu — ele não tem outro sentido. (LACAN, 1957-58/1999, pp. 170-1)

Butler propõe pensar essa "assunção" ao lado da citação da lei simbólica — a materialização do sexo se daria a partir do movimento próprio à performatividade de gênero, dependente da reiteração de práticas sustentadas em regimes sexuais reguladores. Butler entende que, em Lacan, "a lei simbólica tem uma hierarquia semiautômona que é anterior ao momento em que o sujeito assume as posições sexuadas, estas posições normativas, quer dizer, os "sexos" [...]” (BUTLER, 1993/2010, p. 36). O sexo é entendido como função simbólica que tem força de mandamento, cujo impulso normativo se dá a partir do alçamento de seu estatuto a uma lei a ser reproduzida. Contudo, ainda segundo Butler (1993/2010, p. 37), outra interpretação do enunciado lacaniano pode ser feita: 'a lei do sexo' não seria prévia à citação — ela só se produz à medida que é citada. De toda forma, a crítica se sustenta: a materialidade do sexo, que requer processos identificatórios, se dá através da apropriação das normas 
reguladoras pautadas na hegemonia heterossexual, ditando os "tipos ideais" a serem imitados $^{25}$; e o entendimento de "sexo" em psicanálise teria como condição a díade heterossexual tomada como ideal regulatório sob a qual a lei é imposta.

Butler entende o simbólico lacaniano como "o domínio idealizado do parentesco, um conjunto de relações estruturadas através de sanções e do tabu, governado pela lei do pai e a proibição contra o incesto" (BUTLER, 1993/2010, p. 115). Talvez o problema seja de definição: “a diferença com Butler é que a ordem simbólica de que fala Lacan não é um conjunto de regras de comportamento, normas sociais ou uma matriz heterossexual" (SAEZ, 2004, p. 189).

Façamos um parêntese para tratar desse ponto da lei, tão cara a Butler e a Lacan.

Shepherdson (2000) oferece outra interpretação a respeito do sentido de lei em Lacan. Trata-se de se curvar a uma lei pela qual o sujeito entra no campo da linguagem, que o faz existir como sujeito do desejo, não de se submeter passivamente à lei de cunho social como as que determinam relações de parentesco. Fazer equivalê-la à lei da proibição do incesto, no seu sentido antropológico, que toma como base o desejo heterossexual, é uma forma de imaginarização da lei em Lacan - a lei da linguagem não regula o desejo na direção da heterossexualidade, a partir do que se decretariam as práticas sexuais a serem legitimadas, nem impõem as formas de vida a serem aceitas ou rechaçadas. Opor-se à norma, como forma de não submissão a um poder consagrado, não é correlato a opor-se às leis da linguagem. "A 'lei simbólica' não pode ser confundida com a 'lei instituída', com um 'acordo contratual' produzido na história por sujeitos dados a priori" (SHEPHERDSON, 2000, p. 34).

Em Lacan, essa vertente da lei funciona como operação da linguagem que participa do universo psíquico no que tange ao brotar do desejo, nunca totalmente formatado pelo social, e da constituição do sujeito, quando, por exemplo, no Édipo, a metáfora paterna é fomentada — estamos num registro da lei muito diferente da lei jurídica ou daquela que proclama enunciados proibitivos como "não dormirás com tua mãe" no cenário imaginário do drama edípico. Shepherdson não considera que a lei, em psicanálise, seja correlata desse tipo de sanção — ou do tipo "meninos devem ser como

\footnotetext{
${ }^{25}$ Neste sentido, Lacan adverte que é da ética da psicanálise desatrelar o desejo do sujeito da busca de ideais, contudo: "É visível, ao contrário, que, para fugir dessa tarefa, há quem se preste a todos os abandonos, inclusive a tratar, como agora vemos numa obediência freudiana, os problemas da assunção do sexo em termos de papel!" (LACAN, 1959-60/1998, p. 689).
} 
o pai e desejar mulheres" —, mas daquela que institui o princípio de mediações simbólicas puras e da diferença.

Em outra perspectiva, Shepherdson infere que a estrutura da linguagem não é produto de um sujeito autônomo, não é uma lei singular, mas que cada sujeito é um efeito da maquinaria da linguagem. Dois pontos: primeiro, o sujeito da psicanálise é o sujeito do inconsciente; segundo, as experiências subjetivas não alteram a lógica que opera a linguagem. As subjetividades e as sexualidades dependem do tempo e de cada momento histórico; sujeito e sexo em psicanálise, não. As subjetividades que podem contestar normas sociais não são do mesmo registro do sujeito em psicanálise - que é efeito da ordem simbólica e da especificidade de sua lei. Ao sujeito do inconsciente não cabe alterar as leis da linguagem, o que não quer dizer que a psicanálise endosse a docilidade e considere que os indivíduos não tenham força para combater normas sociais que prescrevem tipos ideias de manifestações da sexualidade. Por sinal, seguindo a interpretação de Shepherdson, o sujeito da psicanálise é aquele que nunca se conforma às normas.

Feito esse adento, passemos agora a outro ponto controverso, o falo lacaniano tal como destacado por Butler e a sua teoria do falo lésbico.

\subsubsection{A questão fálica e a saída lésbica}

Pode-se interpretar que a passagem pelo Édipo "normalizaria" e "humanizaria" o sujeito, fazendo com que seu sexo e seu gênero fossem estruturas correspondentes. Os casos de incoerência, incongruência ou disparidade conduzem à ilação clínica de que o sujeito não atravessou adequadamente o Complexo de Édipo, relegando-o ao campo da psicopatologia psicanalítica. O movimento clínico crucial que atestaria essa passagem seria a localização do falo no campo do Outro, operação realizada por meio da metáfora paterna, no interior da qual o significante do Nome-doPai faz função fundamental. Butler recusa essa concepção do Complexo de Édipo, neurocêntrica e hetenormativa, cujo desfecho é a formação de uma identificação de gênero e uma escolha de objeto sexual específicos.

No Lacan dos anos 1953-1960, com o advento da castração simbólica, a diferença sexual é implantada a partir da instituição do falo como significante: "Ser o falo" referir-se-ia à posição feminina. No homem prevaleceria a dialética do "ter o falo" (LACAN, 1958/1998, p. 701). 
Fica evidente que essa formulação psicanalítica ratifica o tão combatido mandato heterossexista de inteligibilidade do gênero, só que agora trazendo o falocentrismo para a discussão. Butler recusa o postulado da binaridade dos sexos, expresso pela centralidade do falo como organizador único da sexualidade. Seu caráter ontológico, denunciado por expressões como "ser e "ter", constituiria uma contradição intrínseca à estratégia lacaniana:

Em termos lacanianos, perguntar sobre o "ser" do gênero e/ou do sexo é confundir o próprio objetivo da teoria da linguagem em Lacan. $\mathrm{O}$ autor contesta a primazia dada à ontologia na metafísica ocidental e insiste na subordinação da pergunta "o que é?" à pergunta "como se institui e localiza o 'ser' por meio das práticas significantes da economia paterna”. (BUTLER, 1990/2003, p. 74)

Além desse suposto "deslize ontologizante" lacaniano, essa concepção da diferença sexual pensada nos termos 'ser' e 'ter' o falo traz outro problema.

O falo freudiano, como significante, muda de função em Lacan: primeiro como significante da falta - que, além de responder à diferença sexual, representa a falta-a-ser produzida pela linguagem em todos os sujeitos (SOLER, 2005, p. 28); segundo, do ter ou não ter o pênis, caminhamos para ser o falo ou tê-lo. A falta fálica na mulher é convertida na possibilidade de ser o falo, o que falta ao Outro, ocupando o lugar de objeto (no amor, a mulher pode se converter naquilo que ela não tem) (SOLER, 2005, p. 29). Isso quer dizer que a mulher só seria passível de ser definida nos termos de "ser o falo" para o Outro, o que daria peso à crítica falocêntrica machista sofrida pela psicanálise. Ora, a mulher só é na medida em que entra na relação com o homem, nunca em si, deixando em aberto a seguinte questão: e quando ela não está na relação com o homem? De toda forma, a crítica feminista se sustenta: a sexualidade feminina, nesse momento da obra lacaniana, continua a ser abordada com referência ao homem.

O dito de Lacan nos parece dar força a essa interpretação: "Não é à toa que lhes repiso desde sempre que o amor é dar o que não se tem. É esse, inclusive, o princípio do complexo de castração. Para poder ter o falo, para poder fazer uso dele, é preciso, justamente, não o ser” (LACAN, 1962-63/2005, p. 122). Além do mais, permite-se depurar aqui um ideal de complementariedade entre tais posturas fálicas, entre homem e mulher.

Mas retomemos nosso percurso em Butler. Segundo ela, nos desenvolvimentos lacanianos o entendimento de homem e mulher parte do pressuposto 
equivocado de que há uma substância intrínseca a eles, mesmo que deslocada para a linguagem, agora sob a roupagem do falo concebido como uma referência universal a partir da qual as posições masculinas e femininas são dedutíveis.

Em Bodies that matter (1993), Butler parte de "O estágio de espelho como formador da função do eu" (1958/1998) e "A significação do falo" (1958/1998) de Lacan, ao discorrer sobre o falo. O estágio do espelho revela o momento em que o corpo imaginariamente despedaçado passa a obter um aparato morfológico especular totalizado - a integridade da imagem corporal é o que condicionaria as futuras relações epistemológicas objetivais do sujeito, assim como suas experiências narcísicas e identitárias. Já em "A significação do falo" Lacan teria introduzido que, nesse âmbito epistêmico, segundo Butler, o ponto de ligação entre a unidade simbólica e a identidade imaginária reside na função do falo, enquanto função de nó - a ideia de totalidade do corpo se sustentaria no "falo como idealização e simbolização da anatomia" (BUTLER, 1993/2010, p. 120) - nessa leitura, a psicanálise teria se pautado na matriz heterossexual, ao conceber as práticas identificatórias partindo da morfologia corporal, adotando a masculina como referência. Além do mais, é como se o simbólico passasse a prevalecer sobre o imaginário, naturalizando e reificando seus efeitos a partir da lei simbólica, como se todos os objetos a se tornassem cognoscíveis, e toda construção imaginária ficasse submetida aos avatares da significação simbólica - e, consequentemente, da posição do falo. Nesse sentido, para que um corpo em partes obtenha controle, inteireza e seja inscrito sexualmente, faz-se necessária a entrada no aparelho simbólico.

A crítica butleriana ao operador desse registro, o falo, configura-se em dois quesitos: por ter função de fundamento, único organizador da diferença sexual e instrumento da norma heterossexual; e por, de certa forma, ainda estar aderido ao pênis - o que contribui para a hierarquia de gêneros e a supremacia masculina (ROGRIGUES, 2012, p. 44).

Para Butler, a articulação freudiana entre falo e pênis é paradoxal: em alguns momentos, parecem se equivaler - por exemplo, quando se pensa na economia da angústia de castração -; mas em outros, o falo parece mais uma fantasia, uma construção imaginária que imputa ao pênis propriedades idealizadas derivadas do órgão. Butler (1993/2010, p. 123) reconhece que, em Lacan, o falo é um significante originário que gera significações, mas, ao mesmo tempo, não é efeito significante de uma cadeia prévia - o que dá a ele um status privilegiado. Além do mais, o falo confere 
erogeneidade às partes do corpo. A partir da leitura de que o falo, significante maior, mesmo em Lacan, ainda está conceitualmente aderido ao pênis — quer como extensão imaginária, quer como condição simbólica erotizadora do corpo —, Butler denuncia que se corre o risco de manter a preponderância do genital masculino como "centro erógeno", risco esse que ela quer afastar. A libido freudiana é masculina, o falo lacaniano também. Para ela, o falo não deve se restringir a nenhuma parte específica do corpo, mas ser um motor de "transferibilidade erógena". Daí Butler propor a noção de "falo lésbico" como tentativa de sobrepujar o "falo lacaniano" e o princípio de não contradição que o regeria:

Pode-se dize que o falo lésbico intervém como uma consequência inesperada do esquema lacaniano, um significante aparentemente contraditório que, através de uma mimesis crítica, põe como questão o poder ostensivamente originador e controlador do falo lacaniano, ou mais precisamente, sua instalação como o significante privilegiado do poder simbólico. O falo lésbico é o emblema de um movimento que se opõe a relação entre a lógica da não contradição e a legislação da heteronormatividade obrigatória no nível do simbólico e da morfogênese corporal. (BUTLER, 1993/2010, p. 117)

Butler entende que, para Lacan, 'falo' é um significante - e, como tal, não é sinônimo de 'pênis' - mas critica o caráter sintomático com que a psicanálise operaria tal separação. Butler volta-se para Gallop, para quem o esforço declarado e infindável da psicanálise de separar falo e pênis — que, por sinal, nunca é definitivo é um sintoma da própria psicanálise, por insistir em ter o falo e posicioná-lo como central na linguagem: a psicanálise não conseguiria controlar sua significação.

A filósofa questiona até que ponto - ao se dizer 'falo', e não mais 'pênis' - supera-se totalmente, no plano fantasístico a referência ou a "herança" deixada pelo órgão sexual. O falo não é o pênis, o falo simboliza o pênis, mas somente na medida em que se diferencia dele, negando-o em um movimento infindável.

Se o falo deve negar o pênis para poder simbolizar e significar de maneira privilegiada, $\operatorname{logo}$ o falo está vinculado ao pênis, não simplesmente via identidade, mas através de uma negação determinada. Se o falo somente significa na medida em que não seja o pênis, e o pênis é qualificado como essa parte do corpo que o falo não deve ser, logo o falo fundamentalmente depende do pênis para poder sequer simbolizar. De fato, o falo não seria nada sem o pênis. [...] $\mathrm{O}$ que devemos nos perguntar, claro, é por que se dá por evidente que o falo requer essa parte particular do corpo para simbolizar e por que não pode operar simbolizando outras partes do corpo. (BUTLER, 1993/2010, p. 132) 
O que Butler quer exterminar é a ideia de uma suposta descendência que o falo teria do pênis na simbolização primária do corpo e como motor de significações. Tratando do falo lésbico: "o potencial subversivo do falo ressignificável reside na insistência, feita por Butler, de que você não precisa ter um pênis para ter ou ser o falo; e que ter um pênis não significa que você terá ou será um falo" (SALIH, 2013, p. 122). "Ter o falo" pode ser simbolizado em qualquer parte do corpo. Assim, desarticula-se a lógica que estabelece a não contradição entre ser o falo (mulheres) e ter o falo (homens), confundindo tais posições.

O falo lésbico, e todo seu potencial de mutabilidade, ressignificaria o caráter heterossexista do falo tal como Lacan o prescreveria, abalando a convicção naturalizante que atrela falo à morfologia masculina, e que ainda vigoraria na psicanálise.

\subsubsection{A melancolia e a heterossexualidade compulsória}

Butler aponta que, assim como os vínculos primários da criança que participam de sua constituição subjetiva estão sujeitos a relações de poder, seus investimentos amorosos — tratados, agora, a partir da noção de 'pulsão sexual' — também estão. Cabe notar que a pulsão sempre se liga a um objeto. Na visão butleriana de Freud, aqueles investimentos são ordenados ao redor da proibição internalizada da pulsão (BUTLER, 1997, p. 22). Tais proibições funcionam como normas regulatórias que controlam investimentos libidinais, sendo a foraclusão [foreclosure] um dos mecanismos psíquicos em jogo. A foraclusão delimitaria quais são os objetos passíveis de investimento pulsional, ao mesmo tempo impedindo radicalmente que outros o sejam; por fim, decretando as formas de amor possíveis e impossíveis ${ }^{26}$.

\footnotetext{
${ }^{26}$ Há de se distinguir 'foraclusão' de 'repressão'. Para Butler, enquanto a repressão diz respeito a um desejo vivido ao lado de sua concomitamente proibição, com a foraclusão o desejo é estritamente barrado e o sujeito é constituído a partir de uma perda preemptiva. Butler adota o conceito lacaniano, cujo ponto de partida é a Verwerfung freudiana. "Butler claramente usa a foraclusão no sentido lacaniano de exclusão psíquica fundante que não pode ser representada no interior da economia simbólica do sujeito" (CAMPBELL, 2001, p. 43). Se na tradição da psicanálise lacaniana a foraclusão é o mecanismo determinante da psicose - marcada pela foraclusão do significante Nome-do-Pai, que acarretaria a inexistência da significação fálica e a consequente falha de inscrição do sujeito em uma posição sexuada — Butler usa a foraclusão para indicar o mecanismo que regula a instalação das normas heterossexuais e dos investimentos libidinais; e a constituição, na sequência, do sujeito melancólico.
} 
Retomando o tema do gênero sexual e seu papel na constituição do sujeito, Butler aponta que o ideal regulatório é a heterossexualidade, ao passo que a homossexualidade é foracluída. Segundo Campbell, para Butler

a proibição fundacional que forma o sujeito não é a que barra o desejo edípico incestuoso que alicerça a psicanálise clássica, para a qual o desejo já é heterossexual e, por isso, baseado na foraclusão do desejo homossexual. Antes, a proibição fundante impede os investimentos homossexuais que seriam dirigidos aos objetos do mesmo sexo [do sujeito] A identidade heterossexual é então erigida a partir da proibição primária que incide sobre os investimentos homossexuais. (CAMPBELL, 2001, p. 38; trad. nossa)

Consequentemente, a homossexualidade foracluída, vivida com uma perda preemptiva, incita a melancolia, sendo tal processo parte fundamental da constituição do sujeito. É interessante que Butler propõe reelaborar sua concepção de gênero como ato performativo a partir de sua teoria do sujeito melancólico, fruto de uma perda impossibilitada de ser sofrida ou enlutada. Butler passa a considerar que nem tudo é passível de ser performatizado, que há um resto foracluído - no caso, a homossexualidade primordial, impedida até mesmo de ser concebida como possibilidade.

Butler parece ter sido sensível a uma diferença ontológica fundamental entre recalque e foraclusão. Se, no primeiro caso, o que é negado no simbólico retorna no simbólico; no segundo, o que não é inscrito no simbólico retorna no real. Ou seja, a escolha da foraclusão aponta para o interesse nesses fenômenos verificados na descompressão entre os registros.

Recorrendo aos desenvolvimentos freudianos a respeito do luto e da melancolia, Butler sustenta que a identidade heterossexual é constituída a partir da foraclusão da homossexualidade primária, e tal perda nunca pôde ser reconhecida como tal, legitimada, nomeada e, principalmente, enlutada. Por esse motivo, a melancolia surge como efeito do não enlutamento do desejo e amor homossexuais.

Butler também demonstra que a melancolia tem papel central no processo de formação dos gêneros sexuais. Os gêneros masculino e feminino seriam adquiridos, pelo menos parcialmente, através do repúdio à homossexualidade, da proibição de sua entrada no universo discursivo e do estabelecimento do processo de luto:

Parece certo que as posições masculina e feminina, que Freud, nos "Três ensaios para a teoria da sexualidade" (1905), entendeu como 
efeitos de uma conquista laboriosa e incerta, são estabilizadas em parte através de proibições que demandam a perda de certo tipo de vínculo sexual, e demandam tão bem que aquelas perdas não são nem declaradas, e nem enlutadas. Se a assunção da feminilidade e a assunção da masculinidade procedem da realização de uma sempre tênue heterossexualidade, nós podemos entender a força de tal realização como exigência de abandono dos investimentos homossexuais, ou talvez mais insistentemente, antecipando a possibilidade do investimento homossexual, uma foraclusão da possibilidade que produz o domínio da homossexualidade entendida como paixão a não ser vivida ou perda inelutável. (BUTLER, 1997, p. 135 ; trad. nossa)

Na perspectiva butleriana, no Édipo a menina tem de abrir mão de seu amor pelo pai e transferi-lo para outros homens; mas, inicialmente, o amor da menina é pela mãe - amor esse que deve ser renunciado de tal forma que tanto o objetivo quanto o objeto sejam foracluídos. A menina não só não deve deslocar aquele amor homossexual primordial para outra figura feminina, como deve também renunciar a toda possibilidade de estabelecimento de vínculos libidinais com mulheres (BUTLER, 1997, p. 137). Os gêneros sexuais, masculino e feminino, seriam formados, ou assumidos, através da incorporação da fantasia de que pessoas do mesmo sexo ou gênero do sujeito devam ser rechaçadas como possíveis objetos de amor.

Retornando à performatividade, Butler sugere que a performance faz alegoria de uma perda que não pode ser sofrida: "gênero poderia ser entendido, em parte, como o 'acting-out' de um sofrimento não resolvido" (BUTLER, 1997, p. 146).O que não seria performatizado como gênero seria fruto do repúdio-foraclusão de um tipo de amor impossibilitado de ser vivido ou reconhecidamente perdido — daí a origem da repetição que faz parte da gramática dos processos de retorno paródico.

Anos mais tarde, em Undoing gender (2004), Butler afirmará que "a proibição de certas formas de amor se instala como verdade ontológica a respeito do sujeito: o 'sou' de 'eu sou um homem' codifica a proibição 'eu não devo amar um homem"” (BUTLER, 2004, p. 199). Ou seja, aqui se evidencia o papel da prática sexual na autodeterminação de gênero. Nessa obra, Butler esclarece que, para ela, a questão de que se a heterossexualidade é consequência, ou não, da repressão de um amor homossexual primordial não é seu principal foco de interesse. O que realmente importa é "mostrar como a teoria das disposições heterossexuais pressupõe o que lhe abate, notadamente a história erótica pré-heterossexual a partir da qual ela emerge". Mesmo reconhecendo que a triangulação edípica é a condição do desejo, tal evento só ocorreria 
a partir de proibições. "O que me interessa mais, no entanto, é desarticular o processo edípico da tese da heterossexualidade primária e universal" (BUTLER, 2004, p. 200).

Mas o sociólogo e ativista gay Javier Saez rebate, lendo o Édipo como fundador do desejo:

\begin{abstract}
Porém, sabemos que, para Lacan, o desejo não é produzido a partir de uma instância positiva, mas precisamente a partir de uma impossibilidade estrutural do sujeito para encontrar um objeto que nunca esteve ali - objeto que, em Lacan, não tem nenhum gênero específico. Dificilmente podemos assumir, como faz Butler em Bodies that matter, que Lacan está decretando a heterossexualidade como modelo para o sujeito. (SAEZ, 2004, p. 183; trad. nossa)
\end{abstract}

Como forma de apresentar algumas maneiras que esse tipo de entendimento de 'simbólico' e de 'sexo' em Lacan foi recebido, passemos a algumas críticas feitas por autores do universo psicanalítico a interpretações como as de Butler. Num segundo momento, traremos as elaborações de Beatriz Preciado. Dessa forma, analisamos outras facetas desse debate: uma, trazendo respostas vindas do campo psicanalítico aos estudos de gênero; outra, interna aos estudos de gênero.

\title{
2.4.5 Revendo o simbólico
}

Vimo que Butler contesta a noção de 'diferença sexual' fundada a partir da ordem simbólica, pois isso alimentaria a tese de que o que promove inteligibilidade é o enquadramento nas normas da heterossexualidade compulsória. Trata-se de uma teórica que acredita na estratégia de que a incitação a sucessivas repetições performativas teriam um fim subversivo: o panorama de ressignificações da norma pode trazer à tona algo imprevisível e reconfigurar o cenário social. Contudo, para ela, o simbólico lacaniano é estruturado com tal rigidez que a possibilidade de renovação dos gêneros seria inconcebível.

Shepherdson (2000) apresenta outro ponto de vista. Para ele, seria justamente o simbólico o que permite que a sexualidade humana não seja governada por instintos ou guiada pela reprodução sexual — se a sexualidade é plástica, é porque somos marcados pelo simbólico; caso contrário, estaríamos no mundo animal, regidos por períodos de cio. É o simbólico que permite ao sujeito entrar na história: “deve-se distinguir entre formas históricas particulares que uma dada cultura pode instituir para 
sexualidade (sua história), e a inevitabilidade da inscrição simbólica que é constitutiva do animal humano" (SHEPHERDSON, 2000, p. 34).

Assim, na psicanálise, a diferença sexual não é uma convenção, o que não quer dizer que ela não tenha uma história - seu entendimento varia historicamente. $\mathrm{O}$ que o autor parece querer distinguir é a 'diversidade', as diferentes manifestações da sexualidade historicamente observadas, contingentes, do que ele denomina como inevitável, o imperativo da inscrição da diferença sexual que caracteriza o humano. A lei da diferença sexual, assim como a morte, é um imperativo, "não é uma invenção humana e não deve ser colocada no mesmo nível dos papéis sociais que concernem às discussões contemporâneas de gênero" (SHEPHERDSON, 2000, p. 89) - o que faz Shepherdson se questionar se a diferença sexual seria uma diferença ontológica (SHEPHERDSON, 2000, p. 66).

Ragland-Sullivan parece estar de acordo:

A diferença é constituída na e pela ordem simbólica, apesar de hoje em dia ser equivocadamente interpretada por reducionismos biológicos e sociológicos que são, então, encarados dentro da ordem imaginária de julgamentos totalitários, nas quais platitudes opositivas moralizantes (como melhor que / pior que) assumem a direção. (RAGLANDSULLIVAN, 2004, p. 86; trad. nossa)

Não se deve confundir, alerta Shepherdson (2000), o registro simbólico em Lacan com o que se entende por 'construção social de gênero'; e 'diferença sexual', em psicanálise, com 'diferença biológica', baseada na anatomia — qualquer tentativa de enquadrar tais noções em psicanálise sob a díade cultura/natureza desconsidera o que a psicanálise tem de mais específico. A novidade psicanalítica não pode ser contemplada se nos restringirmos ao debate concernente à oposição entre essencialismo biológico e construções históricas que sustenta a disputa política em torno da prevalência de um ou de outro: "esta é precisamente a contribuição teórica da psicanálise: quando se trata de sexualidade, o feminismo não pode recorrer a argumentos triviais sobre cultura e determinação política, mais do que se verter à biologia" (SHEPHERDSON (2000), pp. 18-9). Temos sempre de levar em conta o status do corpo pulsional freudiano e dos três registros lacanianos (simbólico, imaginário e real) — o que o autor considera não ter sido devidamente contemplado pelos estudos de gênero que se verteram a Lacan, e nem mesmo a Irigaray. A diferença sexual deve então ser pensada sempre a partir daquelas três ordens, inabarcáveis pela díade sexo biológico/ gênero cultural. 
Creditar essencialismos às ideias de Irigaray, por exemplo, segundo Shepherdson (2000), seria um erro. O "retorno ao corpo da mãe", proposto por ela, não seria uma incitação à retomada ao corpo biológico; e, por outro lado, sua insistência na representação da mulher não quer dizer que, para ela, tudo se reduz à linguagem — ou que a diferença sexual é só um fato de discurso (SHEPHERDSON, 2000, p. 19). Esse mau entendimento do pensamento de Irigaray é o que teria permitido a leitura de que ela teria concebido a possiblidade da edificação de um "simbólico feminino". Para Shepherdson, nem essencialismo biológico nem essencialismo simbólico: a obra irigarayana não pode ser lida através da lente que opõe duas entidades. Além do mais, Shepherdson (2000, p. 22) também considera que a proposta da feminista de gerar outras imagens associadas à mulher não teria como finalidade alterar o registro simbólico - essa empreitada só faria sentido se se equalizassem simbólico e contexto sócio-histórico, o que não se dá em Lacan e nem na teoria de Irigaray. Ela teria pensado que, para inscrever a mulher na história, numa outra vertente que não a do humanismo do século XIX, é necessário se conceber outra forma de tempo, o que permitira outra forma de tratar a diferença sexual. Nesse sentido, Irigaray não teria tido com meta se voltar contra o simbólico em si, mas contra o patriarcado enquanto sistema sóciohistórico que impede que as mulheres sejam articuladas no discurso ou na escrita.

Ainda sobre o simbólico, Shepherdson (2000, p. 60) também considera ter sido um erro de leitura ter associado o semiótico ao feminino, e o simbólico ao masculino na obra de Kristeva, como se essas ordens pudessem ser "genereficadas" [gendered].

O semiótico não é automaticamente um domínio do maternal ou da identidade feminina, mas um domínio no qual a diferença sexual ainda não está estabelecida, e consequentemente não pode ser vertida em gênero sem retornar a uma diferença sexual dada a priori (baseada no senso comum e na anatomia) que desviam as principais questões que as categorias de Kristeva intentam endereçar. (SHEPHERDSON, 2000, p. 61; trad. nossa)

Entender 'simbólico' como 'masculino' ou como 'lugar do pai' e 'semiótico' como 'feminino' ou 'lugar da mãe' seria um equívoco, uma tentativa precária de sociologizar alicerces teóricos do edifício kristeviano - além de impedir o reconhecimento de que a autora pretendia dar peso ao período pré-edípico, no qual a divisão homem-mulher ou masculino-feminino ainda não foi estabelecida.

Mitchell \& Rose (1985, pp. 45-6) aponta que talvez um preconceito fundamental que tenha afastado as feministas de um olhar mais profundo sobre o 
simbólico em Lacan tenha sido o prisma que impôs uma restrição de leitura desse registro, limitando-o às relações de parentesco descritas por Lévi-Strauss. Talvez uma concepção de simbólico ou linguagem como mediação, troca, ou relação tenha se mantido prevalecente, em detrimento duma visão posterior, fortalecida pela concepção de cisão - cujos efeitos são sentidos, sobretudo, na sexualidade.

Em outros termos, Zizek (in BARNARD; FINK, 2002, p. 72) argumenta que Butler "hipostasiaria" o Outro como algo a priori transcendental e a-histórico. Contudo, quando Lacan afirma que o Outro não existe, o que ele quer dizer, para Zizek, é que justamente não há estrutura formal isenta de contingências históricas — por sinal, tudo o que há são contingências e configurações inconsistentes — ou que o Real é inerente ao Simbólico. Se, para Butler, segundo Zizek (in BARNARD; FINK, 2002), a norma nunca pode ser totalmente efetivada pela imposição de contingências históricas, para Lacan ela também nunca o é, o que equivaleria a dizer que o Outro é inconsistente por conta de um núcleo intrínseco a ele, resistente à simbolização.

Além do mais, Barnard (in BARNARD; FINK, 2002) também enfatiza que o funcionamento do simbólico não ocorre sem a interação com os outros registros. As novidades trazidas por Lacan no Seminário XX com relação à sexualidade feminina, o Outro gozo e o saber testemunham seu interesse sobre o tipo de relação que o simbólico e o real travam, relação essa que afeta drasticamente a regência do simbólico: se sexualidade e saber tendiam a ser pensados em termos de simbólico e imaginário, tais termos passam agora a ser explicitados a partir das relações entre simbólico e real. Ou seja, a ordem simbólica, para além de seu efeito estrutural, comporta também uma fenda, da qual o sexo participa - agora com o real e todo o seu caráter irrefreável em cena.

Zizek censura Butler por desconsiderar o registro do real, tanto no contexto estratégico de incitação a mudanças sociais quanto no papel que desempenha na diferença sexual.

Segundo Zizek, em The ticklish subject (1999), a filósofa teria superestimado o potencial subversivo das reconfigurações performativas que atingiriam o funcionamento do Outro. A estratégia de contínuas incitações performativas só promoveria mudanças parciais, não desmantelariam a estrutura. Pelo contrário, elas alimentariam o funcionamento hegemônico do simbólico, fortalecendo a resistência. A reconfiguração do campo simbólico só seria proporcionada pelo ato ético, real, "pela intervenção do real de um ato" (ZIZEK, 1999, p. 262). Enquanto o ato da fala se 
sustenta em normas simbólicas pré-estabelecidas, o ato ético implica "correr o risco de uma suspensão momentânea do grande Outro, da rede sócio-simbólica que garante a identidade do sujeito; um ato autêntico ocorre quando o sujeito arrisca um gesto que deixa de ser coberto pelo grande Outro" (ZIZEK, 1999, p. 264) ${ }^{27}$. O ato ético é imprevisível, não irrompe calculadamente nem é passível de planejamento. Assim, para que os gêneros ininteligíveis acedam a uma existência legítima e identidades sejam desconstruídas, não basta operar via simbólico, como quer Butler, mas a partir do real sempre em jogo — só assim, na perspectiva de Zizek, transformações tomariam curso.

Esse embate do simbólico em Butler e seu aparente desvio do registro do real incidem também sobre a concepção de diferença sexual. Ainda segundo Zizek (1999, p. 273), Butler não teria levado em conta que, para Lacan, em seus seminários tardios, a diferença sexual nunca pode ser propriamente simbolizada ou traduzida numa norma simbólica que fixa a identidade do sujeito. A diferença sexual, ao longo da obra lacaniana, deixa de ser uma duplicação da diferença significante e passa a ser referida a uma experiência não identitária de gozo.

Zupancic (2012) enriquece esse debate a respeito do simbólico em Lacan, apontando os efeitos exercidos nele pelo real. A filósofa eslovena valoriza a solução butleriana que revela o caráter performativo do gênero. Contudo, aponta que tal performatividade seria uma ontologia da discursividade. É claro que Lacan sempre deu importância ao universo da linguagem, mas há algo a mais. Zupancic afirma que, na medida em que o Um do significante cria seu espaço e começa a povoá-lo (o que, grosso modo, corresponde ao espaço da performatividade), alguma coisa é adicionada a ele. Esse algo a mais é inseparável daquele gesto significante fundador, mas, ao contrário dos mecanismos discursivos de nomeação e criação das essências dos fenômenos, esse algo não tem por gênese as construções simbólicas nem é um efeito destas. Zupancic localiza aqui o real, uma entidade colateral ao registro simbólico e que só é discernível enquanto efeito disruptivo desse campo. Não à toa, ao mesmo tempo em que Lacan fala do Outro como o tesouro dos significantes, também o faz como o Outro do gozo.

O real mancha a pureza do simbólico e é marca do sexo:

\footnotetext{
${ }^{27}$ Esse debate é aprofundado por Butler e Zizek em "Contingency, hegemony, universality: contemporary dialogues on the left" (2000). Para Zizek, o sujeito só pode ser compreendido nas relações topológicas estabelecidas entre os registros do real, simbólico e imaginário, aos quais é atribuída estrutura ontológica e cujo caráter é a-histórico; Butler recusa tal a-historicidade das estruturas em jogo no sujeito. Para ela, não existe estrutura anterior ao social e o sujeito só é constituído nas relações de forças retóricas resultantes da reificação de códigos sociais.
} 
A sexualidade (como o Real) não é algo que existe "além" do simbólico; ela "existe" somente como o encurvamento do espaço simbólico que surge por conta de algo adicional produzido com o gesto significante. Isso, e nada mais, é como a sexualidade é o Real. (ZUPANCIC, 2012, p. 5; trad. nossa)

Porém, Zupancic esclarece que o sexo - que, por sinal, não deve ser nunca confundido com as diferentes manifestações da sexualidade — não é o real num sentido ontológico. Pelo contrário, a psicanálise apresenta a conceitualização de um espaço topológico singularmente curvado, cujo nome é 'real'. Esse algo produzido "curva" o simbólico, o que faz com que esse registro nunca seja neutro, ou meramente estruturado por uma lógica binária que funciona a partir de puras diferenciações como significante/significado ou sincronia/diacronia, mas conflitual, assimétrico, 'não todo'. O real infecta no simbólico outra dinâmica, alterando sua dimensão.

Tais ideias se desdobram em Copjec (1994), que questiona se a diferença sexual é uma diferença especial ou só mais uma diferença dentre outras, como as diferenças de raça ou classe social. Para ela, enquanto essas últimas constam do sistema simbólico, a diferença sexual - um tipo particular de diferença - não; e nessa vertente, assim como Zizek e Zupancic, empenha-se a se contrapor a Butler.

A partir da comparação que traça entre as antinomias da razão e as fórmulas da sexuação de Lacan, Copjec (1994) aponta que a diferença sexual, longe da anatomia e dos papéis de gênero, resulta das demandas lógicas do discurso. Tais demandas lógicas levam a um impasse que é o fato de que é impossível se dizer tudo. A linguagem falha e existem dois modos de falhar: o modo masculino e o modo feminino. A não estabilidade do sexo não se deve ao fato de que os termos da diferença sexual sejam instáveis ou pelo fato de as significações estarem sempre em processo. Quando Copjec fala em 'falha da linguagem', não está se referindo à insuficiência de um objeto prédiscursivo, mas à contradição que a linguagem carrega em si própria: o sexo coincide com essa falha, essa contradição inevitável. O sexo é "a incompletude estrutural da linguagem, e não que o sexo seja em si mesmo incompleto" (COPJEC, 1994, p. 206). Copjec quer dessubstancializar o sexo, tratá-lo como entidade vazia, enquanto Butler ainda o consagraria ao campo da linguagem:

Vinculando o sexo ao significante, ao processo de significação, Butler faz da nossa sexualidade algo que se comunica a outros. Enquanto o fato de que a comunicação, sendo um processo - e, desta forma, contínuo - impede uma completa revelação do conhecimento num 
determinado momento; um conhecimento adicional, ainda assim, está colocado dentro do campo das possibilidades. Quando, pelo contrário, sexo é desvinculado do significante, ele se torna aquilo que não se comunica, aquilo que marca o sujeito como não podendo ser conhecido. Dizer que o sujeito é sexuado é dizer que não é mais possível ter qualquer conhecimento acerca dele ou dela. Sexo não tem outra função senão limitar a razão, remover o sujeito do campo da experiência possível ou do conhecimento puro. (COPJEC, 1994, p. 207; trad. nossa)

Como o sexo não pertence à ordem significante, ele não pode ser desconstruído. Copjec chega a este extremo em sua crítica a Butler: "Sexo é o que não pode ser falado pelo discurso; não é nenhum dos inúmeros significados que tentam dar conta dessa impossibilidade. Eliminado esse impasse radical do discurso, Problemas de gênero, apesar de toda sua fala sobre sexo, elimina o próprio sexo" (COPJEC, 1994, p. 211). Butler teria se restringido a circunscrever o sexo como um produto do simbólico, passível de ressignificaçõos histórico-culturais, enquanto, para Copjec, ele está além do simbólico. Nesse sentido, Butler teria sido deixada para trás por um Lacan que saltou das identificações edípicas para as fórmulas da sexuação.

Por sinal, também podemos reconhecer o simbólico como um registro marcado pela incompletude bem antes dos anos 70, haja vista o trânsito de Lacan do significante da falta à falta de significante, operado na passagem do Seminário 8 ao 9 (FARIA, 2015), crucial para o entendimento do gozo feminino e do aforismo lacaniano A mulher não existe - a partir da relação nada evidente entre simbólico e real, no caso, que contempla o significante da falta de significante no Outro: $S(\mathbb{A})$. Noções correlatas dessa falta no simbólico são "a coisa" e o objeto $a$, excluídos no interior, ex-timo, dentro e fora ao mesmo tempo, resto patológico que exige uma topologia e uma temporalidade própria para se formalizar. Tais noções serão focadas por nós no próximo capítulo.

E também, já como forma de anunciar uma das nossas futuras discussões, é comum no meio feminista o argumento de que, mesmo na sexuação de Lacan correspondente a um momento mais avançado de sua teoria —, a diferença sexual ainda estaria referida a uma binariedade: ao "lado homem" ou ao "lado mulher" das fórmulas da sexuação, ou a gozo masculino e gozo feminino. Nesse ponto, a crítica de Butler de que a diferença sexual, em psicanálise, se mantém refém da marca da binariedade ainda se sustentaria. Contra essa leitura butleriana da psicanálise, Copjec assevera: "de onde vem essa concepção de que a psicanálise opera nessa binaridade? Provém da ideia 
de que as categorias de homem e mulher são complementares, que estabelecem relações de reciprocidade e de que um depende do outro" (COPJEC, 1994, p. 202). Lacan aponta justamente para o outro lado quando diz que "A relação sexual não existe".

Por ora, vejamos como Preciado questiona o entendimento butleriano de gênero e prevê saídas para seus impasses, assim como para o controverso falo psicanalítico.

\subsection{Preciado para além do sistema sexo/gênero}

Beatriz Preciado é um filósofo espanhol cujo trabalho se insere na vertente pós-feminista que incorpora elementos do pós-modernismo e do pós-estruturalismo. Seu manifesto em prol da contrassexualidade é, no mínimo, um dos atos mais revigorantes dos estudos de gênero atuais. Preciado parte de Foucault, Derrida, Deleuze; recorre aos trabalhos Lacan; trava um debate com obras recentemente consagradas - como as de Butler, sobre a performatividade - e faz uso de elementos do feminismo radical de Wittig - que analisa a genealogia da heterossexualidade enquanto regime político. A filósofa também se volta à noção de 'tecnologia' sob a inspiração da "tecnologia de gênero", de Teresa de Lauretis, e dos trabalhos de Donna Haraway, sobre a política do ciborgue. O Manifesto contrassexual de Preciado se reporta às novas tecnologias da sexualidade com fins de romper com o feminismo do momento anterior - que, segundo ela, desconsiderou o corpo como espaço de construção biopolítica —, sem descartar, contudo, a hipótese das construções sociais ou psicológicas de gênero. As práticas contrassexuais privilegiariam ao uso do dildo, a erotização do ânus e as relações sadomasoquistas previstas em contratos como forma de denunciar a tecnologia de poder que rege o sexo.

Para além da contestação dos binários homem/mulher ou masculino/feminino já tão evidenciada, Preciado inclui na discussão a díade natureza/tecnologia, na qual a fronteira entre um e outro, corpo e máquina, é permanentemente negociada. Nesse sentido, a contrassexualidade não exige eleger a heterossexualidade ou a dominação masculina como a origem da opressão, já que se dedica ao estudo das transformações tecnológicas dos corpos enquanto sexuados e submetidos ao gênero, nas quais outra temporalidade intervém.

Preciado vai contra toda formação essencialista do gênero e diferença sexual determinada por estruturas físicas e psíquicas não historicizáveis — assim como 
questiona a potência do modelo construcionista, que prescreve as categorias homem e mulher como fabricações dadas aos moldes de normas culturais. Além do mais, o pósfeminismo dos anos 90 teria sustentado — ingênua e paradoxalmente — sua argumentação em um sistema de oposições dicotômico, ao contrapor os elementos ‘sexo' e 'gênero' como duas entidades metafísicas, o que só alimenta a estratégia de oposição binária que tanto quis combater. $\mathrm{O}$ recurso à tecnologia também permite a Preciado driblar outro par de oposições, agora inscrito no interior dos estudos de gênero e que o filósofo considera como que já devendo ter sido superado há um bom tempo no caso, a díade essencialismo/construtivismo.

Se o construtivismo toma o sexo como um elemento a ser submetido ao gênero, a dimensão corporal se torna praticamente irrelevante, o que seria um problema. Preciado quer fugir da mera confrontação entre os modelos essencialista e construtivista trazendo o corpo para a cena, mas a ser introduzido de uma forma muito particular: através de "órgãos e objetos impróprios aos quais nem o feminismo nem a teoria queer quiseram ou puderam responder" (PRECIADO, 2002, p. 76). O dildo, "oculto atrás da questão mais ampla do "falo lésbico"” (PRECIADO, 2002, p. 61) butleriano, habita uma zona intermediária entre órgãos e instrumentos, uma zona litorânea entre natureza e tecnologia: é o elemento estratégico, por excelência, na empreitada de Preciado. O corpo é encarado em seus "efeitos sócio-políticos das tecnologias do sexo" (SAEZ, 2004, p. 197).

Avançando, Preciado (2002, p. 126) pontua: "Se prestarmos atenção às práticas contemporâneas da tecnociência, veremos que seu trabalho ignora as diferenças entre o orgânico e o mecânico". O pós-humano, nos seus termos, tem seu corpo orgânico inescapavelmente submetido à influência da tecnologia: corpo/máquina, seguindo Haraway. Transplante de órgãos, implantação de próteses de silicone, ingestão de hormônios, intervenções cirúrgicas em sujeitos transexuais, inserção de chips... Preciado considera que, na pós-humanidade, “é impossível estabelecer onde terminam os 'corpo naturais' e onde começam as 'tecnologias artificiais'. [...] Mas no ponto de vista contrassexual, o que me interessa é precisamente essa relação promíscua entre a tecnologia e os corpos" (PRECIADO, 2002, p. 127), o que inevitavelmente atua sobre as estruturas sociais e a forma com que se pensa homem, mulher, gênero e diferença sexual - gênero e sexo devem ser encarados como maneiras de incorporação prostética, cujo caráter de resistência impede toda fixidez. Tudo o que abarca o sexo passa a ser questionado pela entrada no cenário do dildo enquanto prótese. 
Preciado parte da noção de performatividade de Butler, reconhece a tecnologia heteronormativa em jogo que determina o corpo como masculino ou feminino através de invocações performativas ontologizantes; contudo, afirma que

o gênero não é simplesmente performativo (isto é, um efeito das práticas culturais linguístico-discursivas), como desejaria Judith Butler. O gênero é, antes de tudo, prostético, ou seja, não se dá senão na materialidade do corpo. [...] Sua plasticidade carnal desestabiliza a distinção entre imitado e imitador (PRECIADO, 2002, p. 25; trad. nossa).

A vertente do feminismo que privilegiou o construtivismo padece por ter feito do corpo sexuado somente "uma matéria disforme ao qual o gênero viria dar forma ou significado dependendo da cultura ou do momento histórico" (PRECIADO, 2002, p. 25) - além do mais, não teria dado a devida atenção às práticas sexuais concretas, deduz Preciado.

Os órgãos reprodutivos só são considerados sexuais porque uma tecnologia do sexual operou nesse sentido - desejo e orgasmo são produtos. Tal tecnologia restritiva funciona como um impeditivo para que outras partes do corpo também sejam sexualizadas, de acordo com Preciado. "O sexo é uma tecnologia de dominação heterossocial que reduz o corpo a zonas erógenas em função de uma distribuição assimétrica de poder entre os gêneros (feminino/masculino), fazendo coincidir certos afetos com determinados órgãos" (PRECIADO, 2002, p. 22). Nesse caso, a superfície erótica seria restringida aos órgãos sexuais reprodutivos ou às clássicas zonas erógenas descritas pela psicanálise. O sistema heterossexual decreta a masculinidade e a feminilidade a partir da fragmentação do corpo; produz zonas de alta intensidade sensitiva que, posteriormente, serão encaradas como marcas naturais da diferença sexual — fruto da heterodivisão do corpo, mesmo que dissimétrica.

Preciado convoca, então, no contrato contrassexual, a forte presença do ânus; já que se trata, segundo ela, de uma região do corpo não marcada pela diferença sexual, sua erotização não se dá no contexto de reprodução sexual e está fora de uma economia heterocentrada. "No âmbito do contrato contrassexual, os corpos se reconhecem a si mesmos não como homens e mulheres, e sim como corpos falantes" (PRECIADO, 2002, p. 18) - chamados de "pós-corpos ou wittigs" (PRECIADO, 2002, p. 36) - , aos quais todas as posições de enunciação seriam acessíveis. Nessa perspectiva, os corpos seriam equivalentes. 
Como forma de desconstruir a naturalização das práticas sexuais através de tecnologias de resistência, recorre-se ao dildo. Não se trata, então, da estratégia de liberar o que supostamente estava proibido, mas de se enveredar para produção de novas formas de prazer-saber, práticas sexuais que envolvam máquinas, produtos ou instrumentos. $\mathrm{O}$ dildo revela que os órgãos que reconhecemos como sexuais não o são por uma determinação natural, mas fruto de um processo tecnológico que lhes imputa significação. O dildo, maleável, pode se deslocar para diferentes partes do corpo, sem privilegiar umas em detrimento de outras.

Na teoria queer americana e nas releituras perversas da psicanálise que esta fomentou, é preciso procurar as escassas análises do dildo nas discussões mais amplas sobre o "falo feminino", "a inveja do pênis", ou nos textos que tratam da rearticulação da noção freudiana do fetichismo com a de desejo feminino. Teresa de Lauretis, por exemplo, critica o heterocentrismo que permite a Lacan jogar permanentemente com a ambiguidade falo/pênis (para Lacan, o pênis é um órgão genital que pertence aos corpos masculinos, enquanto o falo não é nem um órgão nem um objeto, mas sim um "significante privilegiado" que representa o poder e o próprio desejo, e confirma o acesso à ordem simbólica). Para a autora de The practice of pove [A prática do amor], com Lacan se coloca a questão de ter ou não ter o falo a partir de uma perspectiva heterossexual (que a teoria e a prática psicanalíticas se empenham em encontrar ou em induzir nos sujeitos), na qual a diferença sexual homem/mulher e o ato de copular com vistas à reprodução são a norma. Neste contexto, o dildo ocupa um lugar estratégico entre o falo e o pênis. Ele atua como filtro e denuncia a pretensão do pênis de se fazer passar pelo falo. (PRECIADO, 2002, p. 75; trad. nossa)

Nessa vertente de pensamento, o dildo prestaria um grande serviço à psicanálise tal como lida pela tradição feminista: ele seria o instrumento que permitira reconhecer que falo e pênis não são sinônimos, que a origem da diferença sexual não é o pênis nem que o falo seria um instrumento herdeiro do poder heterossexista. "O dildo não é o falo e não representa o falo porque o falo, digamos de uma vez por todas, não existe", afirma Preciado (2002, p. 63). O falo seria como um elemento transcendental neutro, ao passo que Preciado quer fazer do dildo também um instrumento a ser manipulado na prática sexual - objeto inorgânico, mas que convive com o carnal; abjeto impróprio que não se iguala a nenhum órgão, que embaralha os papéis de homem e mulher e desestabiliza a identidade sexual de quem o manipula. Mas precisemos: seu estatuto não deve, de forma alguma, ser reduzido ao de um mero objeto da prática. Trata-se de um elemento que permite a erotização de diferentes partes do corpo e o 
deslocamento dos pontos orgânicos de produção sexual. Não essencializado, não fixável, ele permite o trânsito e a diferença sem se confundir com ela. Não há natureza que o determine nem órgão ou orifício posto de lado - "qualquer coisa pode se tornar um dildo" (PRECIADO, 2002, p. 65). Nesse sentido, o pênis é somente uma de suas roupagens.

No contexto heterossexual, o dildo "remete à possibilidade transcendental de dar a um órgão arbitrário o poder de instaurar a diferença sexual e de gênero" (PRECIADO, 2002, p. 64); mas, se abre tal possibilidade, o dildo também permite subverter o heterocentrismo ao denunciar o caráter negativo da sexualidade, revelando que o "pênis é um sexo de mentira" (PRECIADO, 2002, p. 68) e que a gramática por trás da significação sexual ditada pelo patriarcado deve ser depauperada. Significação sexual a ser esvaziada e mantida vazia. O dildo faz parte da espécie pós-humana, segundo Preciado (2002, p. 77).

Se Beauvoir desnaturalizou a mulher e o feminismo construtivista a transformou num produto social da diferença sexual, "esse feminismo fracassa ao não empreender as análises desconstruvistas do homem e da masculinidade enquanto gênero" (PRECIADO, 2002, p. 123). Assim como a psicanálise: “A velha canção da psicanálise lacaniana dos anos setenta e oitenta, na qual diferentes vozes, do próprio Lacan a Kristeva, ceticamente se perguntavam, 'existe a mulher?', não conheceu seu correlato, 'existe o homem?', até o aparecimento recente dos 'estudos pós-humanos"” (PRECIADO, 2002, p. 123). A introdução do órgão/máquina no universo do gênero e do sexo faz com que o homem seja deslocado do lugar de "elemento dado" para também ser posto como questão.

Preciado também contribui para a estratégia da mudança implícita ao movimento da escrita feminina:

Quando a contrassexualidade fala do sistema sexo/gênero como um sistema de escritura, ou dos corpos como textos, não propõe, com isso, intervenções políticas abstratas que se reduziriam a variações da linguagem. Os que de sua torre de marfim literária reclamam aos berros a utilização da barra nos pronomes pessoais (e/ou), ou pregam a erradicação das marcas do gênero nos substantivos e nos adjetivos, reduzem a textualidade e a escritura a seus resíduos linguísticos, esquecendo as tecnologias de inscrição que as tornaram possíveis. A questão não reside em privilegiar uma marca (feminina ou neutra) para levar a cabo uma discriminação positiva, tampouco em inventar um pronome que escapasse da dominação masculina e designasse uma posição de enunciação inocente, uma origem nova e pura para a razão, um ponto zero no qual surgisse uma voz política imaculada. O que é 
preciso fazer é sacudir as tecnologias de escritura do sexo e do gênero, assim como suas instituições. Não se trata de substituir certos termos por outros. Não se trata nem mesmo de se desfazer das marcas de gênero ou das referências à heterossexualidade, mas sim de modificar as posições de enunciação. (PRECIADO, 2002, pp. 23-4; trad. nossa)

Não é o caso, então, de se limitar a alterações da língua, mudança de pronomes ou de neutralizar o gênero das palavras, mas de focar posições de enunciação via tecnologias de escrita. Se era comum a confusão das teóricas da escrita feminina entre língua e linguagem - evidente quando propõem que, intervindo na gramática, na estrutura e formação de palavras, mudanças na ordem simbólica ocorreriam —, Preciado aqui parece reconhecer a fragilidade dessa proposta e, mais uma vez, rever e fazer avançar as estratégias feministas.

A negligência cometida pelos estudos de gênero quanto à dimensão corporal que Preciado quer retomar através da tecnologia, projeto que está além do que permite o dispositivo sexo/gênero, faz eco com o esforço de certos defensores da psicanálise para trazer a dimensão do corpo pulsional para o debate - corpo cuja experiência de gozo frustra a tentativa de enquadrá-lo como fato natural ou como um mero produto histórico.

Dez anos depois de Gender trouble, Butler parece reconhecer aquela vertente inconsciente do corpo:

Em geral, eu compartilho a visão de Shoshana Felman em The scandal of the speaking body, no qual ela afirma, seguindo Lacan, que o corpo dá origem à linguagem, e que a linguagem adota o corpo como alvo, e performatiza atos corporais que nem sempre são compreendidos por aqueles que usam a linguagem para atingir determinadas metas conscientes [...]. [...] as significações do corpo excedem as intenções do sujeito. (BUTLER, 2004, p. 199; trad. nossa)

Porchat salienta este momento butleriano de retomada do corpo psicanalítico: “o corpo não acata completamente as normas que impõem sua materialização. [...] A psicanálise lhe propõe um corpo que mostrará que as normas não exercem um controle definitivo, ao menos não sempre" (PORCHAT, 2015, p. 38).

À medida que o corpo é desvirtuado pela linguagem, outra dimensão para além da natureza é inaugurada, o que não quer dizer que ele se torne então um terreno totalmente construído por práticas discursivas ou que seja totalmente controlado por relações de poder prescritas em dado momento histórico: o resto ou excesso, fruto dessa operação, está fora do campo da significação. Mas, então, como tratá-lo? Se Preciado 
recorre ao corpo-prótese incapturável pelo sexo e pelo gênero, Lacan emprega o gozo indisciplinado.

\subsubsection{Revendo o falo}

Assim como Butler, Preciado faz a psicanálise se repensar, notadamente quanto ao estatuto do falo. A crítica de que a psicanálise é falocêntrica prepondera desde os primórdios dentro do feminismo e dos estudos de gênero. O advento da sexuação lacaniana não teria alterado tal cenário - o lacanismo dos anos 70 continuaria encarando o falo como elemento central, mas não mais exclusivo, do sexo. Outros elementos entram em jogo, à medida que o falo é alçado a outro patamar - o de uma função dentro da lógica. Mas, antes de darmos esse passo, outras perspectivas a respeito do falo devem ser mostradas, principalmente levando em conta os três registros.

Para Fink (1998), a castração exige a renúncia a algum gozo, e não ao pênis; daí tanto homens quanto mulheres terem de lidar com tal perda. Esse gozo renunciado, posto para fora do corpo, se dirige ao Outro, e é só nos alienando no campo da linguagem que podemos partilhar alguma faceta desse gozo. Se Freud falava em renúncia pulsional como condição das realizações culturais, Lacan fala em "sacrifício de gozo" (FINK, 1998, p. 126). Uma falta é gerada, a circular no Outro. Fink então reforça que a castração diz respeito à "estrutura de falta-perda em si mesmas" (FINK, 1998, p. 128) e só contingentemente, culturalmente, se associa aos órgãos genitais ou à imagem de tumescência. $O$ falo seria justamente o significante dessa perda. Em outro momento, "é o significante da falta a ser que determina o sujeito na sua relação com o significante" (FINK, 1998, p. 129), ou seja, o significante nomeia o espaço vazio no qual o sujeito advém.

Nos termos de Mitchell \& Rose (1985, p. 42), a diferença sexual se institui a partir do falo. A diferença anatômica figura, ilustra, dá imagem à diferença sexual; ou seja, a diferença sexual na sua vertente imaginária - a ser constatada a partir de uma percepção visível do órgão sexual - é um efeito secundário que só é possível se dar com o advento prévio da instituição da diferença no nível simbólico. O significante fálico, no fundo, é o operador do sistema simbólico que possibilita o mecanismo da diferenciação e da implementação da falta — o corpo se empresta como terreno para sua imaginarização. 
Para que haja constatação da falta de algo, como o pênis, por exemplo, se faz anterior a capacidade simbólica de estabelecimento da falta, a partir do que se conceberia que algo falta ali.

Eu lhes disse, em síntese, que não existe falta no real, que a falta só é apreensível por intermédio do simbólico. É no nível da biblioteca que se pode dizer: Aqui está faltando o volume tal em seu lugar. Esse lugar é um lugar apontado pela introdução prévia do simbólico no real. Por isso, a falta de que falo aqui pode ser facilmente preenchida pelo símbolo; ela designa o lugar, designa a ausência, presentifica o que não está presente. (LACAN, 1962-63/2005, p. 147)

Safouan afirma que "nada pode ser percebido sem a linguagem e é o fato de se inscrever na linguagem que fornece ao percebido uma tela propriamente falando imaginária, sem a qual a falta não pode ser capturada nem afirmada" (SAFOUAN, 2009, p. 56). Para que a privação seja real, o objeto deve ser simbólico. Para que um buraco na estante de livros, real, possa ser alçado à posição de um objeto no simbólico (o livro dito faltante), é necessário o intermédio dessa tela imaginária que consente o objeto em sua ausência, possibilitando o ato de vê-lo faltando.

Faria $(2013$, p. 6) chama a atenção para a distinção feita a partir dos três registros que Lacan opera no Seminário IV: "No real do corpo de um menino e no real do corpo de uma menina, não há falta. O órgão da menina é o que é, assim como o do menino [...] É apenas na perspectiva do registro simbólico que o órgão da menina é interpretável como falta e o do menino como presença". E o real "só será lido assim devido à função de suporte do registro imaginário, que dá consistência à dialética falocastração a partir da referência corporal: presença ou ausência de pênis”.

Nas palavras de Lacan:

Mas não é a redução da privação, sua simbolização ou sua articulação que suspenderá a falta. É isso que convém enfiarmos bem na cabeça, desde já, nem que seja para compreender o que significa, na experiência analítica, a forma de aparecimento da falta a que se chama castração. A privação é algo real, enquanto a falta, por sua vez, é simbólica. É claro que uma mulher não tem pênis, mas, se vocês não simbolizarem o pênis como o elemento essencial para se ter ou não ter, ela nada saberá dessa privação. (LACAN, 1962-63/2005, p. 151)

A privação é de um objeto real, a falta é simbólica. Tratar o objeto simbolicamente é permitir que ele seja encarado a partir da díade presença-ausência. Então só se pode acrescentar uma falta ao real do corpo na medida em que se aciona o simbólico. O imaginário do corpo se oferece como um espaço para sua expressão. O falo pode ser imaginarizado no pênis; mas, nessa leitura, ele não tem como condição 
sine qua non o pênis - apesar de os órgãos sexuais serem elementos propícios à manifestação do jogo presença-ausência. Consta também do funcionamento simbólico a atribuição de valor - o falo é sempre valorizado. Talvez tenha sido a nossa cultura ocidental patriarcalista que tenha eleito o pênis como símbolo a ser valorizado, garantido o poder ao seu portador e relegando os corpos marcados por sua ausência a segundo plano, mas não é o falo que decreta a hierarquia dessa relação — nesse sentido, pode-se pensar que ele só fornece as condições estruturais a partir das quais relações como tais possam ser criadas.

Uma outra forma de nos distanciarmos do sexo em seu registro biológico se dá ao acompanharmos o caso Dora sob a ótica de Lacan: Dora "será levada, com efeito, senão a uma questão acerca de seu sexo. Não sobre o sexo que ela tem, mas - $O$ que é ser uma mulher? (LACAN, 1955-56/1998, p. 197). A partir de então, Dora tentaria responder a tal questão identificando-se com o homem, quem tem o pênis: "O pênis lhe serve literalmente de instrumento imaginário para apreender o que ela não consegue simbolizar" (LACAN, 1955-56/1988, p. 203).

Num momento posterior, Lacan ainda insiste:

O falo, ao enfatizar um órgão, de modo algum designa o órgão chamado pênis, com sua fisiologia, nem tampouco a função que podemos atribuir-lhe, palavra de honra, com alguma verossimilhança, como sendo a da cópula. Se nos referirmos aos textos analíticos, veremos que ele visa, de maneira mais inequívoca, a sua relação com o gozo. E é nisso que eles o distinguem da função fisiológica. (LACAN, 1971/2009, p. 62)

Contudo, outros pontos de vista se mantêm, como este da importante teórica de gênero Teresa de Lauretis (1984):

Apesar das repetidas afirmações de Lacan e dos lacanianos de que o
falo não é o pênis [...], o desejo e a significação se definem, em última
instância, como um processo inscrito no corpo masculino, já que
dependem da experiência inicial - e central - do próprio pênis, de
ter um pênis. (DE LAURENTIS apud SAEZ, 2004, p. 174; trad.
nossa)

Como se vê, as interpretações a respeito do estatuto do falo são múltiplas e divergentes, especialmente na sua relação umbilical com o pênis, como querem certas feministas. Mas, quando passamos do falo como substantivo para o falo enquanto função ou enquanto adjetivo de uma experiência de gozo na teoria da sexuação, estamos ainda mais longe do registro da percepção. Nesse contexto, a confrontação com o falo é 
inevitável para homens e mulheres, e portar o pênis não dá ao sujeito nenhum privilégio.

Se a biologia se pauta numa bipartição sexual que decreta pares, o falo faz objeção a essa classificação binária: o falo faz obstáculo à bipolaridade sexual, afirma Lacan no Seminário XVIII. Nesse contexto, o falo deixa de fazer o papel de "terceiro elemento entre homem e mulher" para ser tomado como função; e devemos levar em conta que a função, segundo Le Gaufey (2007), põe em relação elementos que pertencem a séries disjuntas: "as duas séries que Lacan enlaça ou distingue mediante a função do falo não são, de nenhum modo, homens e mulheres, senão os seres falantes, por um lado, e o gozo, pelo outro" (LE GAUFEY, 2007, p. 81). A função fálica designa a relação do ser falante com o gozo, nessa perspectiva.

Segundo Fink (1998), o falo deve ser pensado nos moldes de uma função, a função fálica, função alienante da linguagem, e não ser equiparado ou imaginarizado ao pênis; nem mesmo, quando alçado ao status simbólico, ser considerado como exclusivo do homem - enquanto a mulher estaria privada dele. Homens e mulheres se referem ao falo, cuja função é crucial no estabelecimento da diferença sexual. "Tudo muda quando ampliamos nossa perspectiva para incluir o real e a significância do significante" (FINK, 1998, p. 131).

Dessa forma, avançamos para a teoria da sexuação lacaniana que trata o falo a partir de um campo nada evidente e que, a nosso ver, ainda não foi contemplado em todo o seu potencial. Novas portas se abrem ao debate entre feminismo e psicanálise. 


\section{SEXUAÇÃO}

“[...] as pessoas sérias, às quais são propostas essas soluções elegantes que consistiriam na domesticação do falo, pois bem, o curioso é que elas se recusam em aceitá-las. E por que, se não para preservar a chamada liberdade, na medida em que ela é precisamente idêntica à inexistência da relação sexual?”

— Jacques Lacan (1971/2009, p. 69)

No Seminário XVIII, é comentando a obra de Stoller — que aborda a transexualidade - que Lacan esboça sua teoria da sexuação.

A experiência transexual é uma manifestação da sexualidade que põe em relevo o dispositivo sexo/gênero estabelecido por Rubin. Fatores como identificação e identidade sexual estão em primeiro plano e prevalecem sobre o sexo biológico, ao sujeito se afirmar enquanto homem ou mulher. Trata-se de uma expressão da sexualidade na qual a escolha de objeto sexual não entra como critério de diagnóstico, haja vista existirem transexuais tanto homo quanto heterossexuais. Ou seja, é sempre importante lembrar, a transexualidade exacerba o caráter independente de sexo, gênero, desejo e práticas sexuais - elementos disjuntos cuja relação é contingencial, como bem destacou Butler.

O que significa passar de um lado para o outro, homem para mulher ou mulher para homem, nessa experiência? Muda-se de sexo anatômico, muda-se de gêneros. Nesse contexto, podemos deduzir que o entendimento que subjaz a diferença sexual, formatada aqui como fortemente binária, se dá sob as prescrições imaginárias identificação, imagem do corpo - e simbólicas — práticas de nomeação, campo discursivo, rede de significante, consentimento legal. Mas a psicanálise não leva em conta só tais aspectos para o seu entendimento da diferença sexual. No cenário psicanalítico, noções como 'desejo' e 'gozo' têm muito mais terreno que 'gênero' — por sinal, a entrada desse termo no debate sobre a sexualidade se deu em meio à psicopatologia e ao diagnóstico diferencial, tal como verificamos em Stoller. De toda forma, o que significaria passar de um lado para o outro no contexto da sexuação lacaniana? Uma coisa é o trânsito possível no universo dos gêneros, outra é no campo do gozo. O que faz emergir a questão: qual o estatuto do sexo para a psicanálise?

A elaboração da teoria da sexuação se dá predominantemente a partir da função fálica e da noção de 'gozo' no que tange à diferença dos sexos. No início do 
Seminário XVIII Lacan tratava do semblante dentro da teoria dos discursos, até que opera um giro e o semblante passa a ser sexualizado. Vamos da teoria dos discursos à teoria da sexuação, na medida em que Lacan concebe os semblantes 'homem' e 'mulher'; parecer-homem, parecer-mulher.

Detecta-se, nesse momento da obra lacaniana, um maior acréscimo de elementos da lógica aos seus desenvolvimentos teóricos. Importante frisar que a linguística não é posta de lado. Pelo contrário, ela continua em primeiro plano, como se faz notar pela recorrência à noção de escrita - acompanhamos o debate que trava com Derrida sobre a arquiescritura, a suposta precedência da escrita com relação à fala, e o caráter performativo da língua, a partir do que Lacan afirma: "a única coisa interessante é o que acontece na performance, a saber, a produção do mais-de-gozar [...]" (LACAN, 1971/2009, p. 46). Há um excedente do processo de performatização, e é esse a-mais que será tratado pelos recursos da escrita lógica. Lacan já anuncia aqui o passo a ser dado.

Sempre importa lembrar que, ao longo de sua obra, Lacan costuma se focar mais detidamente em algumas noções, e a construção de determinado modelo teórico em alguns seminários; e, nos subsequentes, a outras - o que não quer dizer que as anteriores devam ser abandonadas ou que passaram a ter menor importância. Se, inicialmente, a palavra - palavra plena e palavra vazia — é privilegiada, depois outros operadores da linguagem ganham destaque — o significante ganha mais espaço; e, na sequência, o traço e a letra. O tema de escrita, que aparece aqui no Seminário XVIII, num primeiro momento sob interesse da escrita chinesa, é correlato principalmente desse último elemento.

Se num tempo anterior a dimensão do desejo era posta em evidência, sob a égide do significante, nesse seminário temos uma mudança de foco e o real é mais bem tratado - via gozo. Essa passagem se dá ao lado da retomada dos grandes mitos da psicanálise: Édipo e Totem e Tabu. Nunca é demais apontar que Lacan não toma o segundo em detrimento do primeiro, que não dispensa o desejo em prol do gozo, ou o universo significante em favor da escrita da letra. O que temos é um enriquecimento da teoria, e não uma substituição. É importante frisarmos esse momento de passagem da obra lacaniana porque nos parece que tal salto não foi contemplado, ou devidamente contemplado, pelas teorias de gênero a respeito do lacanismo - daí toda nossa insistência e dedicação aos pontos de virada. A transição do modelo da teoria dos discursos para a teoria da sexuação abarca uma novidade a ser condensada em 
aforismos tais como "não há relação sexual" e "A mulher não existe", cujas múltiplas consequências são emblemáticas da especificidade da contribuição que o discurso psicanalítico pode trazer a respeito do tema 'sexo'.

Partimos da hipótese de que, em Lacan, a "não relação sexual” já era anunciada muito antes da ter sido decretada claramente no Seminário XVIII: ela se dava a ver nos desenvolvimentos a respeito do desejo, da falta e do falo, até ser enfaticamente divulgada nesse seminário quanto ao gozo - experiência que envolve o real do corpo, a ser vivida distintamente pelos sujeitos que se posicionam como homens ou mulheres.

Fundamental apontar que "relação sexual", aqui, não diz respeito à relação como ato sexual: o encontro de corpos de homem e mulher com fins de cópula; vem do francês rapport que abarca os sentidos de "razão" e "proporção". O sexual em psicanálise não deve ser confundido com o significado que tem em outros contextos como o da biologia, no que tange à reprodução das espécies. Sexual não se limita à sexualidade, à prática sexual, à escolha de objeto, a sentir-se homem ou mulher, ou mesmo a comportar-se de maneira tida como masculina ou feminina.

Foquemos o movimento do semblante sexual nesse Seminário XVIII. Se, contra Stoller, Lacan já havia pontuado que não existe o núcleo de identidade de gênero — ou seja, nada que assegure ao sujeito; nada que o permita ter a plena convicção de ser homem ou mulher - ; e, na sequência, havia afirmado que, no fundo, caberia ao outro sexo reconhecer se está defronte de um homem ou uma mulher, o que talvez subsumisse uma existência possível para a relação sexual; por fim, Lacan prescreve que tal relação não existe. Se já não era uma experiência individual que asseguraria ao sujeito sua identidade sexual, agora nem uma experiência dialética que envolva o outro: não há identidade homem e mulher e não há relação. Não é à toa que Lacan se volta tanto para o chinês, uma língua que parcializa o caráter de substância e permanência, quanto para a função da escrita matemática, que não se articula em busca de sentido — o que serve a Lacan como crítica espontânea da fórmula elementar da proposição sujeito-cópulapredicado, sendo a cópula representada pelo verbo "ser". Ou seja, pensar homem e mulher, enquanto seres de linguagem, em termos essencialistas é guiar-se por miragens:

Disse que o que estigmatiza essa relação, por ela ser profundamente subvertida na linguagem, é, precisamente, que não há meio - como se fez, no entanto, porém numa dimensão que me parece ser de miragem - de ela se escrever em termos de essência masculina e essência feminina. (LACAN, 1971-72/2012, p. 98) 
Recorrer à lógica e à matemática permitiu escrever $\Phi x$, o falo sendo tomado como uma função, e não um motor de promoção de atributos - homens e mulheres serão tratados também a partir da posição assumida frente à função fálica. Estamos para além de definições como "homens são agressivos" e "mulheres são sensíveis", evidentemente. Inclusive, Lacan já apresenta no Seminário XVIII os fundamentos do que virá a ser sua "lógica do não todo", desenvolvida nos dois seminários seguintes, como forma de caracterizar o mecanismo de funcionamento específico da posição feminina com respeito à função fálica.

Na sexuação lacaniana, destaca-se com clareza a tensão entre desejo e gozo, entre operadores lógicos como 'totalidade' e 'unidade', 'universal' e 'existencial'. A prescrição da diferenciação homem/mulher leva em conta um instrumento conceitual, o gozo, que não pode ser totalmente abarcado por instrumentos simbólicos ou performáticos da linguagem, mas pode ser escrito - temos uma escrita lógica a partir da qual o aforismo "não há relação sexual" será encarado. Por sinal, o tratamento dos paradoxos em que se detém a lógica clássica se sustenta na escrita. Contudo, "a relação sexual não se escreve" e temos aqui um impasse: a relação não pode ser escrita, mas e a não relação? Lacan estaria propondo uma escrita para não relação sexual, e não uma escrita da relação sexual? Nesse sentido, Lacan vai considerar que é possível escrever a função do gozo sexual, "que é propriamente o que constitui um obstáculo à relação sexual. É a função Фx" (LACAN, 1971-72/2012, p. 31). Tal passagem faz eco aos impasses da formalização que Lacan diz, no Seminário XX, lhe interessar: para tratar dos paradoxos, de impasses lógicos, é necessário escrever. A escrita não é da ordem da representação e aqui ela passa a ser o referente: fala-se sobre o que está escrito. É a escrita que permitiria uma fala sobre o sexo como não relação. Mas tal escrita lógica comporta um paradoxo intransponível. Outra lógica, para além da aristotélica, terá de ser acessada na tentativa de tratar a diferença sexual na sua vertente de real do gozo.

Lacan pontua que a experiência gozosa não é sexual no que tange à genitalidade ou à prática sexual: "gozar é usufruir de um corpo". Usufruto no sentido do Direito, de fruir de algo à vontade, nem que seja para "picá-lo em pedaços" (LACAN, 1971-72/2012, p. 31). Фx denota o que se produz da relação do significante com o gozo. Cabe apontar que $\mathrm{x}$ designa apenas um significante a ser sexuado. Se homens e mulheres não são como os animais que tendem a exacerbar suas diferenças de macho e fêmea no período do cio, é por estarem aderidos ao domínio do significante. Contudo, 
não se trata de marcar o significante-homem como distinto do significante-mulher e de chamar um de $x$ e outro de $y$, porque a questão é justamente essa - é como nos distinguimos. É por essa razão que coloco o $x$ no lugar do furo que faço no significante. Coloco o $x$ ai como variável aparente. O que quer dizer que, toda vez que eu lidar com esse significante sexual, isto é, com esse algo que se relaciona com o gozo, estarei lidando com o Фx. (LACAN, 197172/2012, p. 31)

A função é a mesma e vale para ambos os sexos - Lacan não recua no primado do falo, mas dá a ele outro estatuto ${ }^{28}$. Nós existimos enquanto significantes; e Lacan vai tratar de homem e mulher como valores sexuais, tal como o inconsciente os revela — onde não há espaço para um gênero neutro. Homem e mulher, questão de linguagem: "A linguagem é tal que, quanto a todo sujeito falante, ou é ele, ou é ela. Isso existe em todas as línguas do mundo. É o princípio do funcionamento do gênero, feminino ou masculino". Contudo, "dito isto, homem e mulher, não sabemos do que se trata. Durante algum tempo, essa polaridade de valores foi tomada como algo que sustentava, suturava suficientemente o que concerne ao sexo" (LACAN, 1971-72/2012, p. 38). Onde a teoria do conhecimento pretendia dar conta, responder do que se tratava, a psicanálise traz a castração — não se pode decretar categoricamente a verdade última sobre temas cuja abordagem é o sexo. Lacan vai avançar e pensar homem e mulher para além daquela polaridade de valores que prescreveria uma relação e que tomaria como condição a consistência da linguagem - pelo contrário, o valor do homem e da mulher não é abordável em tal sistema. Lacan considera que os instrumentos da linguagem não possibilitam a formalização da não relação sexual: "no que se refere à relação sexual, [...] em tudo o que se aproxima dela, a linguagem só se manifesta em sua insuficiência" (LACAN, 1972-73/2010, p. 116). Daí proclamar que devemos criar uma "nova lógica"

\footnotetext{
${ }^{28}$ Gallop (1982) aponta uma questão interessante: os dois trabalhos de Lacan nos Escritos (1998) que tratam mais diretamente da diferença dos sexos, "A significação do falo" e "Diretrizes para um congresso da sexualidade feminina" são separados por um ensaio que funciona como um comentário à obra "A teoria do simbolismo" de Ernest Jones, de 1916, o que talvez não tenha sido à toa, já que os Escritos de Lacan são uma coletânea cuja disposição dos textos não adotou como critério a ordem cronológica em que foram escritos, mas outro, desconhecido: “ 'A teoria do simbolismo' de Jones, tal como lida por Lacan, contém a principal questão a respeito da articulação lacaniana da diferença sexual"(GALLOP, 1982, p. 15). Jones teria denunciado que, na história, a incidência de símbolos fálicos, aqui sinônimos de órgão masculino, é maior que a incidência de todos os outros símbolos sexuais postos juntos, desproporção esta que ratificaria a injustiça a que mulher é submetida - Freud endossaria tal evidência ao tomar a libido como masculina, dai Jones pretender sanar tal injúria decretando uma libido feminina. Debatendo com Jones, Lacan alça o falo do simbolismo atrelado a ele à sua função enquanto significante e, além do mais, como significante privilegiado - Jones não teria tido acesso às teorias da linguística moderna que permitiram Lacan elevar o falo a tal estatuto, delibera Gallop (1982).
} 
que permita demonstrar "o que pode haver de real na determinação da linguagem" (LACAN, 1971-72/2012, p. 20).

Muito interessante é o episódio que Lacan teve com Beauvoir, que gira em torno dessa discussão e que já indica outro instrumento na abordagem lacaniana do sexo, a teoria dos números, a ser usado à exaustão nos seminários subsequentes:

\begin{abstract}
A função que é chamada 'sexualidade' se define, até onde sabemos alguma coisa sobre ela - e realmente sabemos muito pouco, nem que seja por experiência - , pelo fato de os sexos serem dois, a despeito do que possa pensar uma autora célebre que, na época e em razão de não sei que orientação, já que eu ainda não havia começado a ensinar, julgou que devia se reportar a mim antes de escrever $O$ segundo sexo. Ela me telefonou para dizer que precisava de meus conselhos para lhe dar esclarecimentos sobre o que deveria ser a contribuição psicanalítica para seu livro. Como lhe assinalei que seriam necessários uns bons cinco ou seis meses para que eu elucidasse a questão - isso é o mínimo, pois estou falando há vinte anos, e não é por acaso —, ela me observou que era inconcebível que um livro já em processo de execução esperasse tanto tempo, e as leis da produção literária eram tais que lhe parecia fora de cogitação ter mais de três ou quatro conversas comigo. Ao que declinei dessa honra. (LACAN, 197172/2012, p. 93)
\end{abstract}

Lacan apresenta esse relato - já precioso, por si só, enquanto história para defender a ideia de que não existe um segundo sexo. Só existe um sexo, a partir do momento em que a linguagem funciona. Heteros, presente em 'heterossexualidade', aponta para “outro" - mas 'outro' enquanto ausente, sem substância; 'outro' que está direcionado ao esvaziamento como ser na relação sexual. "É precisamente esse vazio por ele oferecido à fala que eu chamo de lugar de Outro [...]" (LACAN, 1971-72/2012, p. 93). O Outro está sempre ausente quando se trata da relação sexual, e "isto não é, de modo algum, forçosamente um privilégio do sexo feminino, mas simplesmente a indicação de que escrevi no meu grafo [...] sobre o Significante de A barrado" (LACAN, 1971-72/2012, p. 102).

Ainda seguindo Lacan, heteros se distingue de deuteros — este aponta para o que se faz em uma segunda vez, ou ao que está em segundo lugar, ou seja, não é nesse sentido que Lacan trata do heteros. Diferença: um e outro, e não dois. "A coisa de que se trata, quando se trata de sexo, é do sexo oposto, até quando se prefere o mesmo a ele" (LACAN, 1971-72/2012, p. 149). Lacan considera que a ideia de dois sexos, concernente à de bissexualidade, tem como base o modelo animal que adota o modelo da relação sexual entendido como cópula entre seres ontologicamente distintos. Pressupõe a ideia de universalidade e de duas totalidades de equivalência oposta: todos 
de um lado têm relação com todos do outro; ou o que vale para cada um (qualquer um) vale para todos os seres que se colocam desse lado, assim com se daria com os seres do outro - a partir do que se constrói a farsa do 'a cada um, sua cada uma'. "O que nos dá a ilusão da relação sexual no ser falante é tudo o que materializa o universal num comportamento que, efetivamente, é de bando, nas relações entre os sexos" (LACAN, 1971-72/2012, p. 95). Não existe a relação sexual no ser falante porque o que está em jogo aqui é a função fálica, válida para homem e mulher. A questão é como distinguir dois elementos a partir de um termo comum.

Consideramos que o tema da não relação sexual já vinha sendo prenunciado por Lacan. A dissimetria entre os sexos já se revelava a partir de noções como 'desejo' e 'fantasia'. Com o gozo, preferencialmente abarcado pela lógica e pela matemática nos Seminários XIX e XX, o caráter de não relação no que compete ao sexo em psicanálise é escancarado. Para tratarmos disso, um recuo se faz necessário. Devemos discorrer brevemente sobre o que entendemos ser a especificidade do sexo nesse contexto.

\subsection{Para o sexo psicanalítico}

"O mau encontro central está no nível do sexual." — Jacques Lacan (1964/1998, p. 65)

Poderíamos falar em uma teoria unificada a respeito do sexo em psicanálise, como questiona Dunker (2016)? Tanto em Freud quanto em seus continuadores parece que o sexo é tratado sob vários aspectos: pulsão, vida amorosa, construção do erotismo, prática sexual, chegando até a apresentar indícios de gênero sexual - quando se recorre a termos como 'masculinidade' e 'feminilidade', entendidos como identificações sexuais decorrentes do percurso edípico. Em psicanálise,

não há conceito ou tema que não possa ser remetido direta ou indiretamente à sexualidade. Mas com esse movimento, o que se verifica é uma expansão da conotação de sexualidade [...], essa teoria geral da sexualidade parece estar por toda parte e ao mesmo tempo em nenhuma, de modo claramente isolável. (DUNKER, 2016, p. 180)

Ou seja, o estatuto do sexo em psicanálise é algo completamente flutuante. Tanto tomado como chave de leitura para a pulsão freudiana quanto para a sexuação lacaniana, sexo se distancia largamente, a nosso ver, de modelos normativos que 
pregam que deva haver adequação entre sexo e gênero e que a heterossexualidade genital e o amor "complementar" devem ser o alvo almejado no itinerário libidinal. Pelo contrário, sexo, ao ser desvirtuado pela linguagem, confunde-se com desejo e gozo elementos que implementam a contingência e a intransigência no universo das normas.

Foucault nos servirá como um contraponto aqui, para apresentar um dos alicerces da teoria queer, a ser comentado posteriormente por Copjec na sua tentativa de localizar o sexo em psicanálise.

[...] o projeto de uma ciência do sujeito começou a gravitar em torno da questão do sexo. A causalidade no sujeito, o inconsciente do sujeito, a verdade do sujeito no outro que sabe, o saber, nele, daquilo que ele próprio ignora, tudo isso foi possível desenrolar-se no discurso do sexo. Contudo, não devido a alguma propriedade natural inerente ao próprio sexo, mas em função de táticas de poder que são imanentes a tal discurso. (FOUCAULT, 1976/1988, p. 80)

Para Foucault, a verdade dos corpos está intrinsecamente vinculada às práticas de poder de determinado contexto sócio-histórico. Tais práticas funcionam como dispositivos reguladores; e se, ao longo do tempo, são reconfigurados, novas verdades são produzidas - dessa forma, o entendimento da sexualidade (e da diferença sexual) depende da discursividade em jogo. Na contemporaneidade, a questão do que marca o humano passa inescapavelmente a se vincular com a temática do sexo, nos vários sentidos que este tem: o sexo biológico atribuído (assigned) no nascimento, o papel social e as funções desenvolvidas (gênero) e a atividade sexual. Sexo não deve ser entendido como "sexo-natureza" - concepção essa que, por sinal, também é resultado de um discurso sobre o sexo —, mas como "sexo-história" ou "sexo-discurso", anexado a uma racionalidade que nos imputa uma lógica dos desejos e dos prazeres do corpo.

Até o final do século XVIII, segundo Foucault, três códigos regiam as práticas sexuais: o direito canônico, a pastoral cristã e a lei civil — a partir deles, demarcavam-se o lícito e o ilícito. A referência, o foco de atenção era a relação matrimonial, marcada de prescrições, recomendações e cuidados. Romper as leis do casamento e ir atrás de prazeres que violariam as regras eram condenáveis. Com o século XIX, a sexualidade passa a ser pública; vai do ambiente privado à publicidade dos poderes médicos, jurídicos, sociais, através dos dispositivos de sexualidade. O casal detém a verdade da sexualidade, a monogamia heterossexual é a regra e o que foge a isso é tido como anormal - é daí que nasce o conceito de anomalia e anormalidade, a 
partir dos quais se funda o conceito de norma: "heterossexualidade" nasceu a partir da definição das anomalias.

Apesar de ainda persistir a manobra política de limitar o sexo à função reprodutiva e à legitimidade matrimonial (dispositivo de aliança), a partir do fim século XVIII quatro grandes conjuntos estratégicos despontam como dispositivos específicos de saber-poder a respeito do sexo. São eles: histerização do corpo da mullher; pedagogização do sexo da criança; socialização das condutas de procriação; e psiquiatrização do prazer perverso. Tais subgrupos compõem o que Foucault denomina dispositivo da sexualidade e comportam técnicas disciplinares e procedimentos reguladores. Cabe ressaltar aqui que a sexualidade não é entendida como um dado da natureza, mas como uma produção, uma "grande rede da superfície em que a estimulação dos corpos, a intensificação dos prazeres, a incitação ao discurso, a formação dos conhecimentos, o reforço dos controles e das resistências, encadeiam-se uns aos outros, segundo algumas grandes estratégias de saber e de poder" (FOUCAULT, 1976/1988, p. 117).

Na sociedade ocidental do século XVII, grosso modo, podemos dizer que era pela repressão que o poder atuava no campo do sexual. Temos aqui a famosa hipótese repressiva da sexualidade, da qual, segundo muitas teóricas do gênero, a psicanálise seria herdeira. Nos três últimos séculos, numa sociedade como a nossa marcada pela disciplina e ortopedia dos corpos - a estratégia de poder regente é outra, mais sutil e sofisticada do que a que se detém na mera repressão. O que muda na sociedade disciplinar é a forma jurídico-discursiva do poder. Essa forma é baseada na lei, que proíbe. A psicanálise, ao prescrever uma lei regida pelo simbólico, ratificaria tal submissão à lei, agora na forma de uma lei do desejo? Essas duas fases — o sistema monárquico centralizado do poder, onde prevalece a lei que pró́be; e o desejo a ela correspondente, hipótese supostamente psicanalítica, na visão de teóricas como Butler — podem ser tomadas como correspondentes? Schepherdson já ofereceu a interpretação de que a lei do sexo não se confunde com regulamentações normativas.

Mas retornemos. É importante ressaltar que essas novas práticas de poder, que não podem ser tomadas como sinônimos de 'repressão', em Foucault são entendidas como jogo de forças relacionais, micropoderes; agem por normas e têm caráter produtivo. Ao contrário da negatividade que marcava as atuações do poder até o século XVII - na qual se evidenciava a rejeição, não manifestação, censura e esquiva dos assuntos referentes ao corpo - , posteriormente a proposta é tomar a direção oposta, 
agir positivamente. Ainda mais, restringir a análise do poder somente a sua vertente de repressão tem, no fundo, a intenção de estrategicamente ocultar sua principal face de atuação. Muito mais do que um mecanismo negativo de exclusão, trata-se de um mecanismo positivo de produção de saberes - saberes multiplicadores de discursos, indutores de prazeres e geradores de poder - a ser disseminado nos corpos, postos cada vez mais a se pronunciar. Pouco a pouco, os mecanismos de poder foram se desatrelando das representações do direito e da lei para se articularem também ao funcionamento da técnica e a ideais de normalização e controle — da lei à norma.

Interessante notar que, com a nova pastoral ${ }^{29}$, o dispositivo da sexualidade prevaleceu, mas não substituiu definitivamente o dispositivo da aliança. De certa forma, unem-se um ao outro; e a família burguesa é o terreno privilegiado onde se constata tal conjugação. A família burguesa leva a dimensão jurídica para dentro do dispositivo da sexualidade, ao mesmo tempo em que provoca uma economia de prazer a ser intensificada e levada para o interior do regime da aliança. E a psicanálise é considerada o plano que une esses dois dispositivos, que acha as leis da sexualidade no centro da aliança familiar. $\mathrm{O}$ dispositivo da sexualidade recentra a família, o que produz novos personagens, como o marido impotente ou sádico, a esposa frígida e o jovem homossexual que se volta contra o casamento. Na sequência, médicos, pedagogos, "especialistas" são convocados para dar conta desse novo sofrimento sexual resultante das infelizes interferências entre os campos da sexualidade e da aliança.

Tomada como alvo de investigação médico-científica, a sexualidade é racionalizada. O sexo é observado, especificado, classificado, dissecado. Sob imperativos morais e pelas normas médicas guiadas pelo ideal da fisiologia da reprodução animal, aberrações sexuais e perversões sexuais são produzidas e as menores extravagâncias e oscilações da sexualidade são problematizadas. Investiga-se por onde passa o prazer físico dos sujeitos. Entra aqui em jogo a psiquiatria, que se pronunciaria a respeito dessas doenças mentais que se manifestavam no âmbito da sexualidade e que iam contra o imperativo da reprodução sexual. Estabelecem-se diagnósticos e propõem-se terapêuticas. Os infindáveis exames médicos e questionários incitam o mecanismo prazer-poder e sua manifestação heterogênea nos corpos, ao invés de soterrar as sexualidades errantes.

\footnotetext{
${ }^{29}$ Foucault defende a interessante tese de que o Estado moderno representa uma espécie de poder pastoral secularizado, mundanizado. Assim como o poder pastoral havia sido a matriz da produção da verdade dos próprios indivíduos, o Estado moderno poderia ser considerado a matriz moderna dos processos de individualização, como uma nova forma de poder pastoral.
} 
Ao lado da psiquiatria, também se convocava a justiça penal — afinal de contas, perversões eram também lidas como crimes ou ultrajes. Contudo, a intenção real não era simplesmente condenar ou tolerar os "desvios", mas administrar o sexual, inseri-lo num sistema de utilidades. Trata-se, então, não de excluir certas práticas sexuais, mas de observá-las insistentemente, especificá-las, distribuí-las e administrá-las através do Estado.

Ao contrário do momento anterior no qual falar de sexo era algo secreto, a partir do século XVIII fala-se cada vez mais de sexo. Tudo deve ser dito. A ciência do sexo escancara-o de forma crua com a intenção de mostrar o que estava escondido sob o véu do poder repressivo que atuava sobre as condutas irregulares e os prazeres excessivos.

No século XIX, o sexo foi constituído como o objeto privilegiado detentor da verdade do sujeito - na verdade do sexo se esconde a verdade do sujeito. A incitação a falar sobre o sexo se deu nos moldes do mecanismo da confissão. Confessase ou se é obrigado a confessar os crimes, pensamentos, desejos e prazeres individuais aos médicos, educadores e juízes em busca da verdade escondida, intencionalmente ou não, pelo sujeito.

Contudo, para acessar tal verdade, não bastava simplesmente pôr o sujeito a falar; ela não vem pronta e acabada na fala do confessante. $O$ funcionamento do sexual é obscuro e cheio de desvios, daí a necessidade de quem escuta também interpretar tal interpretador não se reduz ao papel de juiz ou do dono do perdão, mas é aquele que decifra, completa o que é lhe é enviado (aquele que tem uma chave, um saber, uma hermenêutica do sexo). Em termos clínicos, o processo da confissão, além de funcionar como instrumento de elaboração diagnóstica, promove efeitos terapêuticos - a verdade cura quando dita a tempo. Não parecem ser poucos os paralelos que Foucault induz o leitor a fazer com a psicanálise e a figura do psicanalista.

A proposta é que, para que o sexo deixe de ser reprimido, deve-se falar cada vez mais dele. Contudo, falar cada vez mais contra os poderes libertaria o sexo? Pelo contrário. A incitação a se falar cada vez mais do sexo, essa coerção a falar, é a própria repressão - funcionando como estratégia de ocultamento da vertente da sexualidade que opera como dispositivo. Na Idade Moderna, prevalecia um discurso unitário sobre o sexo, organizado sobre o tema da carne e a prática da confissão. No decorrer dos séculos, tal discurso foi multiplicado e fragmentado em discursividades distintas: biologia, medicina, psiquiatria, psicologia, moral, crítica política — ou seja, cresceram 
os aparelhos inventados para se falar sobre sexo e fazê-lo falar. Paradoxo próprio aos jogos de poder na sua vertente mais astuta: a produção discursiva e seus efeitos de poder que pretendem formular a verdade do sexo, essa vontade de saber, servem no fundo para ocular algo mais importante. Não se trata então de negar que, ainda na Idade Contemporânea, o sexo seja passível de interdições e mascaramentos, mas sim investigar o que leva tal concepção a vigorar como elemento fundamental e constituinte da sexualidade. Reduzir o sexo a tal hipótese repressiva constitui uma tática discursiva, uma técnica de poder.

Ainda mais, além de o dispositivo da sexualidade sustentar a ideia de que a verdade do sujeito está vinculada ao seu sexo, decorre desse próprio dispositivo o princípio da representação que se tem hoje de sexo. Agrupam-se sob tal termo, como uma unidade artificial, elementos anatômicos, funções biológicas, condutas, sensações e prazeres - sendo a biologia e a fisiologia os campos de saber que passaram a ditar os princípios de normalidade da sexualidade humana. A ideia de sexo opera uma reversão essencial: escamoteia as relações de poder intrínsecas a ela, constituídas a partir do dispositivo da sexualidade, tornando-as visíveis somente em sua relação com a lei e a interdição.

Trazendo Copjec (2012) para a discussão, podemos vislumbrar outro meio de visibilidade ao sexo, fora do contexto da sexualidade enquanto dispositivo. Para ela (COPJEC, 2012, p. 38), sexo não é um fator a ser libertado — porque ele não é passível de ser reprimido ${ }^{30}$, como prevê a hipótese repressiva de Foucault. Reprimidos só podem ser representações, não afetos e gozo - que, por sua vez, só podem ser deslocados. Nesse ponto, Copjec se distancia de Foucault, sem desconsiderar a estratégia de tratar do sexo biopoliticamente.

$\mathrm{Na}$ vertente foucaltiana, o sexo foi encarado como detentor de leis próprias, algo sob o qual elementos disjuntos e incomensuráveis - como os anatômicos, as funções biológicas, as condutas, as sensações e os prazeres — poderiam ser reunidos artificialmente como tentativa de ser controlado. Mas Copjec considera que sexo, em psicanálise, deve ser entendido de outra forma.

Além do mais, a invenção do sexo segundo Foucault teria favorecido a tese de que a construção do sujeito pode se dar de forma completamente individualizada. $\mathrm{O}$ múltiplo no lugar do sujeito dividido da psicanálise. A respeito do Seminário XX,

\footnotetext{
$\overline{{ }^{30} \text { Copjec usa o termo inglês repression. }}$
} 
Copjec (2012, p. 40) considera que "em retrospectiva, todo esse seminário pode ser lido como um golpe preemptivo contra a má intepretação de Foucault a respeito da problemática do sexo em Freud". Nesse momento de Lacan, sexo é tratado dentro do aforismo "não há relação sexual"; o que, por sua vez, se provocou interesse em alguns, foi posto de lado por certas teorias feministas. Acompanhamos esse mesmo efeito hoje quando nos voltamos aos estudos de gênero que se verteram à psicanálise. Mas, antes, adotemos o conselho de Copjec de retorno ao básico.

Numa certa leitura, pode-se dizer que em Freud há a consideração de que a evolução libidinal tem como meta final a genitalidade. A pulsão sexual seria totalizada ao redor do órgão sexual com fins de reprodução na conclusão do percurso edípico. A posição masculina e a feminina seriam complementares, nesse sentido. Esse Freud se fiaria ao caráter compulsório da heterossexualidade; no entanto, outra leitura é possível.

A teoria pulsional freudiana já mostrava, tal como interpretada por Lacan, que, "em relação à finalidade biológica da sexualidade, isto é, a reprodução, as pulsões, tais como elas se apresentam no processo da realidade psíquica, são pulsões parciais" (LACAN, 1964/1998, p. 166). Ou seja, o que comanda a sexualidade humana são as pulsões, que, como tais, desvirtuam a meta reprodutiva - heterossexual, portanto - a ser perseguida por uma suposta pulsão genital totalizada e integrada. Pelo contrario: "A pulsão é precisamente essa montagem pela qual a sexualidade participa da vida psíquica, de uma maneira que se deve conformar com a estrutura de hiância que é a do inconsciente" (LACAN, 1964/1998, p. 167).

A sexualidade do ser falante é instaurada no roteiro da falta. Ainda mais radicalmente, Lacan aponta que duas faltas se recobrem: uma, fruto do advento do sujeito em relação ao Outro, sua submissão ao significante; e outra, "a falta real, anterior, a situar no advento do vivo - quer dizer, na reprodução sexuada. A falta real é o que o vivo perde, de sua parte de vivo, ao se reproduzir pela via sexuada" (LACAN, 1964/1998, p. 195). Guiar-se pela reprodução implica essa perda real. Nesse sentido, a realização sexual ser equiparada à reprodução sexual é um logro, porque sexo em psicanálise é outra coisa. Entendemos que a teoria pulsional freudiana, nessa leitura empreendida por Lacan, apresenta argumentos que relativizam a consideração de que todo o arcabouço teórico da psicanálise se pauta em prescrições heteronormativas.

Se abandonarmos esse ideal da realização genital, apercebendo-nos do que ele tem de estruturalmente enganador, felizmente enganador, não haverá razão alguma para que a angústia ligada à castração não nos 
pareça estar numa correlação muito mais flexível com seu objeto simbólico e, portanto, numa abertura inteiramente diferente com os objetos de outro nível. Isso, aliás, é implicado desde sempre pelas premissas da teoria freudiana, que coloca o desejo, quanto à sua estruturação, numa relação totalmente distinta de uma relação pura e simplesmente natural com o chamado parceiro natural. (LACAN, 1962-63/ 2005, p. 288)

Como seres de linguagem, estamos no campo do desejo, o que desnaturaliza qualquer determinação biológica que impulsionaria o sujeito na busca de um parceiro heterossexual com fins de reprodução. A sexualidade, desde os "Três ensaios sobre a teoria da sexualidade" (1905) de Freud, tem sua essência polimorfa. O alvo da pulsão não é um objeto da realidade, sua satisfação "não é ave que vocês abatem, é ter acertado o tiro e, assim, atingido o alvo de vocês" (LACAN, 1964/1998, p. 170) — o alvo é um retorno em circuito, que acaba contornando o objeto, sempre faltante. A pulsão oral, por exemplo, não visa ao alimento, mas ao objeto $a$ que envolve a boca. O objeto $a$ é, nesse contexto, o objeto da pulsão, eternamente parcial, a se manifestar como oral, anal, escópico e vocal. O objeto $a$ é o objeto em torno do qual circula a pulsão, sem que o desejo seja extinto. "Esse objeto suporta o que, na pulsão, é definido e especificado pelo que a entrada em jogo do significante na vida do homem lhe permite fazer surgir do sentido do sexo" (LACAN, 1964/1998, p. 243).

Copjec tem a interessante tese de que o sexo se localiza nas lacunas da linguagem. Segundo ela, Freud pretendia pensar sexo e causa juntos, pressupondo um sujeito sob determinação (COPJEC, 2012, p. 32). Sexo como causa não pode ser localizado em fenômenos positivos, unívocos ou múltiplos, ou em objetos específicos, já que a pulsão não é instinto e não se confunde com a necessidade de ir em busca de elementos particulares. O domínio do sexo seria, então, o de fenômenos negativos como lapsos — interrupções que apontam para a descontinuidade, impondo a desordem ou desvirtuamento da cadeia causal mantida em tempo cronológico.

Isso pode ser verificado, para Copjec (2012, pp. 35-6), na experiência de Emma, paciente de Freud: num primeiro momento, quando tinha 8 anos, o vendedor de uma loja, rindo, abordou-a sexualmente tocando os genitais da menina. Tal cena, contudo, não se configurou para ela como invasão ou abuso sexual naquele momento; somente anos depois, ao entrar sozinha numa loja de roupas, Emma dali saiu correndo assustada ao ver dois vendedores rindo, pensando que riam de seu vestido. Esse segundo incidente atualiza a cena anterior, trazendo seu caráter sexual para frente, como 
se fosse a primeira vez. A origem do sexual se dá, então, em duas fases: na primeira, o sexo está ausente da experiência; na segunda, por sua vez, está ausente da ação que o provocaria. O sexo tem dimensão de enigma, como uma função de suspensão do sentido, não localizável.

Além disso, o sexo, como revela esse exemplo recuperado por Copjec, tem uma relação muito específica com o tempo. Nesse sentido, sexo não tem essência e é submetido à historia do sujeito. Sexo e tempo teriam a mesma estrutura, além de estarem originalmente relacionados. Tanto na lógica temporal que rege o funcionamento psíquico quanto na lógica sexual presente na história de Emma, na qual dois momentos são divididos por uma ruptura, a repetição falha duplamente: "o segundo repete o primeiro, mas não exatamente - essa não coincidência [...], é a falta de sincronia que a repetição repete" (COPJEC, 2012, p. 37). Anacronismo de Emma, o passado é infectado pelo presente deslocado - introduzindo, hoje, uma sexualidade muito cedo para ser experenciada na ocasião —, assim como o presente parece ser contaminado pelo passado também fora de lugar - daí a experiência atrasada do sexo como um resto da cena originária. "Muito cedo/muito tarde: esses são os tempos da sexualidade, assim como os tempos do tempo em si" (COPJEC, 2012, p. 37). Isso faz com que Emma se lembre do que ainda não aconteceu como se já tivesse acontecido - é nessa experiência temporal que se dá o brotar do sexo. Para Copjec (2012, p. 38), os estudos de gênero não levariam em conta essa problemática da repetição, que incide sobre as noções de sujeito e tempo, como intrínseca ao sexo.

Já para Saez (2004), os estudos queer não levariam em conta o real e o objeto $a$. O sociólogo espanhol que tem importante trabalho sobre a interface entre estudos queer e psicanálise, apresenta uma leitura rara da tese lacaniana em meio aos teóricos de gênero, e aponta que:

O caráter subversivo de Lacan não deriva da tentativa de produzir elementos imaginários alternativos à normalidade - ou normatividade - , mas de apontar um campo que resiste a qualquer intenção de adaptação: esse campo é denominado como "real", irredutível. Lacan critica radicalmente qualquer ideia de desenvolvimento psicossexual normal e os ideais sobre o amor implicados à psicanálise [...]. Enquanto o discurso queer denuncia a construção do sexo em suas facetas imaginárias (imagens) e discursivas (simbolicamente), Lacan situa o sexo do lado do real. (SAEZ, 2004, pp. 168-9; trad. nossa) 
Nesse sentido, ainda segundo Saez, como não há objeto privilegiado no campo do sexual, abrem-se ao sujeito do inconsciente múltiplas sexualidades que não heterossexuais, levando a "um paradigma que não é nem essencialista-biologicista nem discursivo-performativo" (SAEZ, 2004, p. 173). Não orgânico e nem discursivo: sexo em psicanálise deve ser pensado sempre junto ao real.

Ragland-Sullivan (2004) segue a leitura de Saez ao não considerar que a psicanálise lacaniana alimenta a heteronormatividade compulsória e se debruça sobre a questão de como ser homem e mulher se não há representação inconsciente de ambos. Afirma Ragland-Sullivan (2004, p. 77) que frente à falta intrínseca ao sexo, construímos precariamente mascaradas para sermos socialmente reconhecidos como homem ou mulher. Referente a Butler, Ragland-Sullivan aponta que:

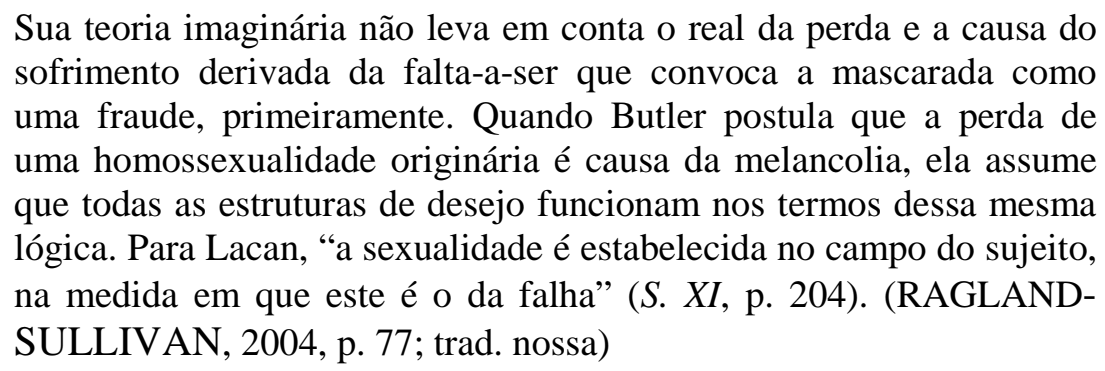

Falha essa que corresponde à estrutura de um vazio que não pode ser equacionado nem à homossexualidade nem à heterossexualidade - o sexual, em psicanálise, está para além da sexualidade; a pulsão não tem objeto pré-determinado e não se guia por atos sexuais pré-concebidos. Tal como reconhece Saez,

A visão de Lacan da sexualidade mostra que o desejo não está
determinado pelo gênero do objeto eleito, mas pelo objeto $a$, que é
algo independente do gênero. Ao separar desejo de gênero, Lacan está
separando o desejo da heterossexualidade como norma. (SAEZ, 2004,
p. 164; trad. nossa)

Importante, então, tratarmos do estatuto desse objeto em questão no sexo.

A pulsão é uma força constante que não pode ser erradicada; ela é determinada pela busca de satisfação marcada pela impossibilidade. "O gozo é interditado a quem fala como tal" (SAFOUAN, 2009, p. 41). Essa seria a consequência da descoberta freudiana a respeito do estatuto pulsional do objeto frente ao qual a busca de satisfação é marcada pela repetição da falha. Nos termos de Lacan (1964/1998, p. 71), o real é cúmplice da pulsão. Como impossível, faz obstáculo ao princípio do prazer, inaugurando esse movimento infindável: “O real é aqui o que retorna sempre ao mesmo 
lugar - a esse lugar onde o sujeito, na medida em que ele cogita, onde a res cogitans, não o encontra" (LACAN, 1964/1998, p. 52). O objeto $a$, na sua vertente do objeto pulsional, causa o desejo; ele não é um objeto capturável e sempre uma volta a mais em torno dele é convocada. Seria essa a faceta do sexo que o dispositivo da sexualidade, tal como prescrita por Foucault, tenta em vão reprimir na sua estratégia de multifacetá-lo? Fatorizar o sexo na tentativa de controlar seu caráter disruptivo e imprevisível?

“[...] o pequeno a é a causa da Spaltung do sujeito" (LACAN, 197172/2012, p. 226), no que participa da composição da fantasia. Lacan usa termos como "des-ser", "dejeto" e mesmo "abjeção" para se referir à condição desse objeto. Um objeto perdido antes de existir enquanto objeto: não é que primeiro existe o objeto e depois ele é perdido, mas que ele é perdido antes de existir enquanto objeto - e nisso Copejc (2012, p. 45) capta seu parentesco com a coisa freudiana.

Por fim, o efeito do significante no sujeito faz com que seu objeto seja marcado pela evanescência, e é essa a marca do sexo. Da necessidade ao desejo; da meta reprodutiva à meta enquanto satisfação pulsional marcada de parcialidade; do alvo heterossexual aos percalços do enquanto objeto $a$, assexual; do determinado ao indeterminado; da genitalidade à dispersão do gozo pelo corpo; da sucessão cronológica à uma lógica anacrônica. O percurso imposto pelo gozo transgride os comandos do princípio do prazer e "uma outra realidade intervém" (LACAN, 1964/1998, p. 174). "A realidade do inconsciente é a realidade sexual", afirma Lacan (1964/1998, p. 143).

Uma precisão há de ser feita: a parcialidade em Freud diz respeito à pulsão. Quem fala em objeto parcial é Lacan. Se é parcial, não é totalizável, não faz um. Como formalizar o caráter não unário do objeto? Le Gaufey considera que esse foi um problema que atormentou Lacan por longos anos.

Segundo Le Gaufey (2007), se no estágio do espelho o objeto especular cai num tipo de unidade imaginária (sujeito e objeto sairiam da mesma matriz especular). $\mathrm{O}$ das Ding freudiano, no Seminário VII, permite a Lacan conceber um objeto não narcíscico e que escapasse à representação, um objeto cuja existência rompia com a positividade. Lacan quer pensar uma unidade negativa que permaneça a mesma na repetição. Quais seriam, então, as relações do objeto com o 'um', se não se trata de unidade imaginária nem simbólica? Justamente as prescritas pelo objeto parcial, de acordo com Le Gaufey (2007, p. 66). Lacan trata então de discorrer sobre a propriedade agalmática do objeto no Seminário VIII, objeto que, nesse contexto, não se presta a nenhuma totalidade, concebido como objeto a desvinculado do pequeno outro; em 
outros termos, aproximando-se do objeto kantiano vazio, que se subtrai à unidade do conceito - o objeto que se desvincula de toda relação com o 'um', a partir da ausência do conceito.

O tratamento desse objeto $a$ e sua relação com a unidade numérica se dará com a série de Fibonacci, desenvolvida no Seminário XVI. Depreende-se dessa formalização que, quanto mais a série significante se estende, melhor se circunscreve o objeto $a$, sem tocá-lo nunca. Contudo, tal série, segundo Le Gaufey (2007. p. 77), é incapaz de fornecer o estatuto do 'um' que Lacan quer dar a seu objeto parcial estatuto esse de uma não relação. Passa-se então aos esforços topológicos de figuras não especularizáveis, tais como a banda de Moebius, a garrafa de Klein e o cross-cap. Mas em vão: nenhum recurso matemático, tal como o número irracional raiz de 2 , brindou Lacan com o material para sustentar seu objeto parcial sem precedentes, na ótica de Le Gaufey (2007, p. 78). Se Lacan distingue a unidade em ‘unário' (simbólico) e 'uniano’ (imaginário), a parcialidade desse objeto escaparia a ambas as vertentes. Teria sido justamente com a sexuação que Lacan teria conseguido tratar desse objeto na sua pretensão de não relação com o 'um'. 'Um' aqui em sua dimensão real, tal como quer Copjec.

Em outros termos, Copjec (2012, p. 42) questiona que, se o sexo não pode ser deduzido nem da biologia nem das convenções sociais, seria ele o terceiro elemento a fazer a ligação entre natureza e cultura? Não, sexo não sutura os dois; pelo contrário, é o que provoca a disjunção entre um e outro, assim como a disjunção interna a cada um deles. Sexo é justamente o que impede a relação entendida como ligação ininterrompida. 'Não há relação sexual' deve ser lida ao lado de Há-um. O sexo é o inimigo do Um totalizado.

\subsection{Diferença sexual, dois e um}

Segundo Safouan (2009), a sexualidade feminina foi, ao longo da história, a pedra no sapato da psicanálise. No entre guerras, travou-se um acirrado debate quanto a seu estatuto - sempre tendo como pano de fundo o complexo de Édipo e a castração. Podemos dizer que a oposição a Freud se dava também pelo fato de ele tratar de sexo e diferença sexual em torno do Um. A castração é um percurso único que tanto menino quanto menina deveriam percorrer enquanto sujeitos sexuados; a libido é única; só há um falo, masculino. Claro que isso provocou como reação um movimento para pensar a 
especificidade da mulher; para pensar o quanto seu corpo anatômico deveria ser levado em conta como diferença a repercutir na sua sexualização enquanto sujeito. Da tematização sobre a distinção do sexo passa-se para o que o sexo feminino traria de valoroso à Mulher (MITCHELL \& Rose, 1985, p. 20). Nos anos 20, Melanie Klein, Karen Horney, Helene Deutsch e Jeanne Lampl-de Groot foram figuras centrais nesse debate - ao lado de Ernest Jones, que ia contra a suposta postulação freudiana de que o feminino é um elemento negativo ao qual só cabe a construção. Jones pregava que se nasce mulher, e não que se torna uma. Nesse sentido, a constituição do ser sexuado envolveria dois caminhos distintos.

Safouan traz a genética para o debate: "a existência dos dois sexos é inegável e legível nos dois marcadores genéticos XX e XY” (SAFOUAN, 2009, p. 54). Contudo, por que tal resposta não decide e encerra a discussão sobre o que determina a diferença sexual? Safouan $(2009$, p. 54) chama a atenção para o fato de que a questão principal não é se há dois sexos ou não — esse nível cromossômico já o atestaria —, mas que não há universal da mulher quando se trata do ser da linguagem. Nessa leitura, geneticamente, mulher existe; já para a psicanálise, "A mulher não existe": a barra da negação nesse aforismo lacaniano não se dá sobre mulher, mas sobre $A$, como forma de grafar a não universalidade da mulher.

Não existe substância que permitiria definir o homem ou a mulher, o que não quer dizer que a diferença dos sexos manque. Safouan ainda aponta que

essa falta de essências não significa uma falha na realidade da diferença dos sexos. Essa realidade existe; ela está inscrita nos códigos genéticos. Mas essa realidade é, por si só, muda. É somente graças à linguagem que ela se inscreve como oposição e diferença. Em uma só palavra, não temos nenhum acesso a essa realidade fora das transposições linguageiras e de suas ressonâncias imaginárias. (SAFOUAN, 2009, p. 47; trad. nossa)

O próprio Lacan não fecha os olhos aos fatores biológicos do sexo. Quanto à diferença sexual no que compete a diferenças anatômicas, à "pequena diferença [...] destacada desde muito cedo como órgão, o que já é dizer tudo - organon, instrumento" (LACAN, 1971-72/2012, p. 13), Lacan não a nega. Não é que não leve em conta que não existe diferença sexual nesse nível, que poderíamos considerar como correlata da diferença sexual manifestada no nível do humano enquanto espécie.

Essa diferença que se impõe como inata é, com efeito, muito natural. Corresponde ao que há de real no fato de que, na espécie que se 
denomina homo-sapiens [...], os sexos parecem dividir-se em dois números mais ou menos iguais de indivíduos. Bem cedo, mais cedo do que se espera, esses indivíduos se distinguem, é certo. (LACAN, 1971-72/2012, p. 15)

Certo, Lacan reconhece que os indivíduos se distinguem anatomicamente: os corpos são diferentes, o animal humano é dividido em macho e fêmea. Mas delimita seu campo e adverte seus ouvintes: "Não é que eu negue a diferença que existe, desde a mais tenra idade, entre o que chamamos de uma menina e um menino. É inclusive daí que parto. Captem desde já, que quando parto daí vocês não sabem do que eu estou falando" (LACAN, 1971-72/2012, p. 13). Até porque a diferença sexual é captada antes dos shifters "menino" e "menina" serem assumidos pelo sujeito que fala.

No que compete ao humano - enquanto espécie dividida em gêneros, no plano biológico —, segundo Lacan (1971/2009, p. 194), não há representação psíquica como tal: "No psiquismo, não há nada pelo qual o sujeito pudesse se situar como ser de macho ou ser de fêmea”. Como somos seres falantes, o que se passa nesse nível biológico não basta: "eles só se reconhecem como seres falantes ao rejeitarem essa distinção através de toda sorte de identificações" (LACAN, 1971-72/2012, p. 16). É só através do semblante que o sujeito se dá a ser reconhecido, enquanto homem ou mulher, frente ao Outro.

Daí Freud ter concebido que, psiquicamente, homem e mulher aparecessem como atividade e passividade, atributos identificatórios. Freud tentou, dessa maneira, metaforizar o insondável da diferença sexual; mas a relação masculino-feminino não é passível de ser reduzida a tais termos opostos, "a oposição masculino-feminino jamais é atingida [...] - essa oposição atividade-passividade escorre, se molda, se injeta. É uma arteriografia, e as relações masculino-feminino mesmas não a esgotam” (LACAN, 1971/2009, pp. 181-2). Tratar da diferença sexual por termos atributivos que se contrapõem, como ativo e passivo, no fundo é uma tentativa de "suprir o que de modo algum pode ser dito [...], ou seja, a relação sexual” (LACAN, 1972-73/2010, p. 172).

$\mathrm{Na}$ tentativa de diferenciar sexualmente as crianças, dotando-as de traços específicos, Lacan aponta que "nós [as] distinguimos, não são [elas] que se distinguem" (LACAN, 1971-72/2012, p. 16). O outro estabelece diferenças entre menino e menina a partir de comportamentos, atitudes e preferências, comumente oriundos da pequena diferença que existe entre eles - a criança é falada nessa diferença. Por exemplo, quando, como insistiu Stoller, a partir da visão do órgão sexual do filho, os pais já passam a lhe atribuir expectativas de gênero: 
mas não é preciso isso para que o juízo de reconhecimento dos adultos circundantes se apoie em um erro. Esse erro consiste em identificá-los, sem nenhuma dúvida, por aquilo que ele se distinguem, mas em reconhecê-los somente em função de critérios formados na dependência da linguagem. [...]. (LACAN, 1971-72/2012, p. 16)

Seria um equívoco, então, decidir tratar-se de homem ou mulher a partir do corpo e imputar expectativas de gênero a partir dele; além do mais, porque tal articulação parte de recursos da linguagem.

Ao trazer para o debate a experiência de gozo, Lacan recorre à transexualidade, desvinculando-a da qualificação de mudança na experiência do eu imaginário. $\mathrm{Na}$ transexualidade, seguindo Lacan, se o sujeito reconhece que o órgão sexual não é só um pedaço de carne - mas um órgão desnaturalizado pela linguagem ao qual são destinados significados —, esse sujeito, ao querer livrar-se do órgão enquanto significante, incorreria no "erro comum que não vê que o significante é o gozo e que o falo é apenas o significado" (LACAN, 1971-72/2012, p. 17). Nesta perspectiva, passar ao outro sexo estaria, antes de um tudo, relacionado a uma mudança na experiência de gozo, o que não entraria em jogo na dinâmica do trânsito próprio à transexualidade. Daí o deslize, o não se dar conta de que a diferença sexual se manifesta também via gozo e registro real. Daí a corrente questão intrínseca ao campo psicanalítico, de se a diferença sexual via gozo tenderia, na obra lacaniana, a ser a diferença sexual por excelência, a que sobrepujaria as outras formas de conceber a diferença sexual - presumindo uma hierarquia entre os registros. Pensamos que não.

"Como homem ou como mulher, o ser humano tem sempre que aprender, peça por peça, do Outro" (LACAN, 1971/2009, p. 194), mas há um limite para esse 'aprendizado'. Falta no Outro a representação de homem e mulher: o Outro é barrado. Isso abre o campo da relação, que supostamente permitiria ao outro reconhecer tratar-se dele ou dela, dia e noite — mas não, tal como já havia apontado Fraisse (2010) a respeito desta antiga forma de se debruçar sobre a diferença sexual retomada por Lacan. A relação de oposição, ou qualquer outra forma possível de se estabelecer qualquer tipo de relação entre os sexos, só se dá mediante o falo, determinante de toda significação, o que já era anunciado por Lacan desde os anos 50.

Se lhes falei do dia e da noite é para lhes fazer sentir que o dia, a própria noção do dia, a palavra dia, a noção da vinda do dia, é alguma coisa, propriamente falando, de inapreensível em alguma realidade. A oposição do dia e da noite é uma oposição significante, que ultrapassa 
infinitamente todas as significações que ela pode acabar por recobrir, e mesmo qualquer espécie de significação. Se tomei como exemplo o dia e a noite é porque naturalmente nosso tema é o homem e a mulher. (LACAN, 1955-56/1988, p. 226)

É possível abarcar o homem através do escrito científico da biologia como "homem = portador de espermatozoides" (LACAN, 1971-72/2012, p. 28), contudo não há como se escrever o que tem relação com o real. E real aqui não tem nada a ver com a biologia ou a ciência, como defende Morel (2000). Trata-se da relação sexual tal como atrelada ao discurso psicanalítico. Então, o real é o que "comanda toda a função de significância [...]" (LACAN, 1971-72/2012, p. 29) e impossibilita a apreensão dos significantes em sua totalidade.

Antes de nos aprofundarmos nesse Lacan da não relação sexual, pensamos ser importante tratarmos mais a fundo o tema do 'um' e do 'dois' no contexto histórico da diferença sexual.

Com Freud, o atravessamento do percurso edípico, único percurso tanto para homens quanto para mulheres — sendo o falo nele participante para ambos - não revela uma simetria: "Para a mulher, a realização de seu sexo não se faz no complexo de Édipo de uma forma simétrica à do homem, não pela identificação com a mãe, mas ao contrário pela identificação com o objetor paterno, o que lhe destina um desvio suplementar" (LACAN, 1955-56/1988, p. 197). E qual seria o motivo de tal dissimetria? A diferença anatômica entre os sexos, absoluta - em certa medida, é como se Freud se pautasse somente no plano imaginário. Já para Lacan (1955-56/1988, p. 201), “[...] a razão dessa dissimetria se situa essencialmente ao nível simbólico". Num primeiro momento, teríamos em Freud um sexo - universalidade do falo, ou seja, não há determinação biológica para o reconhecimento de dois - , para que depois, atravessado o Édipo, percurso que depende de fatores históricos e culturais, a menina possa reconhecer que o seu órgão sexual por excelência é a vagina - outro órgão, não uma versão do pênis, tal como o clitóris tendeu a ser encarado. Em Freud temos um e dois, num certo sentido - isomorfismo e dimorfismo, nos termos de Laqueur, cujo trabalho "Inventando o sexo: corpo e gênero dos gregos a Freud" (2001) é indispensável à pesquisa nessa perspectiva.

Nessa obra fica evidente que, ao longo da história, não é possível conceber que o corpo sexuado esteja imune a mudanças sociais e políticas, como se tivessem limites fixos no espaço. Os corpos foram interpretados de diferentes maneiras ao longo da história. 
Laqueur vai contra a ideia de que o "dimorfismo sexual" é a verdade dos corpos; contra a concepção de que a natureza dita que existem dois corpos, corpohomem e corpo-mulher, radicalmente contrários, diferenciados pelo aparato biológico. Nem sempre na história um sinal do corpo era o que apontava para a diferença sexual. Além do mais, a genitália passou a ser a marca de tal diferença muito recentemente. Tudo depende da interpretação dos corpos e da estratégia política por trás do entendimento da sexualidade de cada momento histórico.

Da Antiguidade clássica até o século XVIII prevaleceu a ideia de que o corpo-homem e o corpo-mulher não eram opostos — vigorava o "modelo do sexo único". Galeno, no século II, demonstrava que, ao nível dos órgãos sexuais, as mulheres eram essencialmente homens, mas homens "virados para dentro". O órgão sexual feminino era visto como um pênis interno e o útero, como escroto, por exemplo. Os fluidos reprodutivos eram versões um do outro e o que diferenciava o sêmen masculino do feminino era o fator potência, a ser determinado pelo "calor vital". Basicamente, era a quantidade de calor o que diferenciava o masculino do feminino, demarcando o grau de perfeição do ser: homens tinham mais calor, eram mais potentes e tomados no final do eixo "perfeição". O padrão de tudo era o homem e a mulher era definida com relação ele. Na verdade, se o corpo da mulher não fosse encarado como uma versão do homem, ela estaria fora da categoria humana.

Ou seja, nesse período, a fronteira entre o masculino e o feminino é de grau, e não de espécie. Dois gêneros correspondem a apenas um sexo - e o gênero, anterior ao sexo, marcava o corpo. Suspeitava-se que homens frios, menos potentes, teriam maior probabilidade de ter sangramentos menstruais e de desenvolver leite, por exemplo. Inclusive, existia o receio de que homens que convivessem demais com mulheres pudessem vir a desenvolver alterações fisiológicas na direção da feminilidade.

O que se considera por gênero hoje em dia era, para Aristóteles, uma "verdade natural". Sinais físicos como o pênis, fortemente tido na contemporaneidade como marca determinante do homem, para ele eram observações contingentes e filosoficamente pouco interessantes. Homens e mulheres são distintos, mas quanto à divisão de trabalho e à atribuição específica de poder. Grosso modo, homens são ativos e mulheres, passivas; homens saem de casa e adquirem bens, mulheres permanecem em casa e os preservam. Os corpos não serviam de base para distinções ontológicas. Determinados eram os papéis políticos dos homens e das mulheres. De toda a forma, no modelo de sexo único, as fronteiras do sexo lidam com poder e legitimidade. 
Mas por que no Renascimento, período marcado pela exatidão e ilustração naturalista, ainda se insistia em pensar a anatomia e a fisiologia reprodutiva de maneira errada e contra intuitiva, tomando a anatomia genital feminina como um rascunho da masculina? Uma análise histórica sugere que nesse período perseguir a evidência dos órgãos ou dos vasos sanguíneos não era relevante - tudo dependia da política cultural de representação do sexo. Por exemplo, nesse período foi feita a constatação de que a secreção vaginal das mulheres não se parecia com o sêmen masculino, mas mesmo assim ela foi insuficiente para abalar a forma como os corpos sexuados eram encarados. A própria descoberta do clitóris por Renaldo Colombo, em 1559, foi facilmente absorvida pelo modelo de sexo único: tratava-se do pênis feminino.

É interessante notar que não existia, nesse momento, um vocabulário próprio para a anatomia genital feminina; pois, se o que distinguia o corpo-homem do corpomulher eram hierarquias metafísicas, não havia necessidade da criação de uma nomenclatura precisa que diferenciasse os sistemas reprodutivos um do outro.

Até o século XVIII, para a manutenção das fronteiras sociais entre homens e mulheres, havia de se manter estabilizadas e intransponíveis as categorias de gênero para tanto, rígidas leis suntuárias dos corpos foram criadas. Por exemplo, a mulher ativa na relação sexual — portanto, na posição considerada tipicamente masculina — corria o grande risco de ser acusada de tríbade, por violar a lei do gênero.

Em algum momento do século XVIII, o sexo tal como o entendemos hoje foi inventado e um novo modelo passou para o primeiro plano como forma de se contemplar a diferença sexual, o do dimorfismo, muito embora o modelo de uma só carne não tenha morrido - estudos do desenvolvimento fetal parecem dar crédito ao antigo modelo de androgenia, agora não mais sustentado no plano metafísico, mas no da natureza.

Definitivamente, foi a partir do século XIX, segundo Foucault (1976/1988), que passou a haver a proliferação do discurso de que a sexualidade em geral tem sua origem na biologia dos corpos. O discurso científico pauta-se no modelo reprodutivo para opor radicalmente o corpo do homem ao da mulher. Com o tempo, tal diferenciação passa a ter estatuto de fato originário e a ser encarada como determinada pela natureza. Os corpos, divididos em dois sexos estáveis e incomensuráveis, justificariam as desigualdades hierarquizadas entre o masculino e o feminino, assim como determinariam a divisão binária dos gêneros e seus respectivos papéis, lugares sociais, culturais e políticos. A partir de então, os órgãos sexuais passaram a ser 
distinguidos no campo da língua, como "ovários" e "testículos", e a vagina passou a ter um nome específico.

Com o modelo de dois sexos diferentes prevalecendo, passou-se a constatar que orgasmo feminino e fecundidade não andam juntos - se para o homem, seu orgasmo é condição para a fecundação da mulher, da parte dela tais fatores não estão ligados, como se acreditava anteriormente. A partir daí, a ciência passou a se interessar pela frigidez feminina, que não significa esterilidade, e outros temas relacionados ao prazer feminino - cabe destacar que é nesse contexto histórico que surge a figura de Freud, como alguém que se predispõe a ouvir o que as mulheres tinham a falar da especificidade de seus corpos e paixões, até então inauditos: "É somente com Freud que a fala das mulheres sobre a sexualidade, de um tempo no qual eram submetidas ao silêncio, se vê liberta" (LEGUIL, 2015, p. 78). A mudança de paradigma faz, então, que a sexualidade feminina passasse a ser assunto de cada vez mais interesse.

Importante sublinhar que então o corpo da mulher se tornou um campo de batalha para redefinir a antiga relação social entre homens e mulheres. Já no século XVIII - e, com mais ênfase, no XIX pós-revolucionário - cresciam as lutas feministas (e antifeministas) pelo poder e posições na esfera pública: o sistema de fábricas reestruturou a divisão sexual do trabalho; nasceram as classes sociais e o livre mercado. Tais mudanças andaram ao lado da reconstrução do copo sexuado. A distinção anatômica do sexo passa a dar sustentação para a legitimação das reivindicações sociais e políticas das feministas. A linha divisória entre homens e mulheres deveria se tornar mais visível: só assim elas poderiam ser reconhecidas enfática e explicitamente como diferentes - e, consequentemente, lutar para ocupar espaços na sociedade até então reservados aos homens. Se num primeiro momento do feminismo se reivindicava igualdade com relação aos homens, a tendência de acirrar diferenças foi adotada como principal estratégia da onda feminista posterior, pondo em relevo uma essencialização dos sexos com suas diferenças irredutíveis, como vimos com Irigaray. Obviamente, Wittig e os estudos queer se inscrevem na terceira onda feminista: a desessencializadora. O que nos faz considerar, nesses termos, que a teoria da sexuação lacaniana também seria desessencialista, ao contemplar existências negativas; ao passo que a teoria que se detinha em tomar o homem ao lado do ter e a mulher, do ser adotando o falo como tema universal - seria diferencialista. A sexuação, como veremos, também comtempla a fantasia; e, nesse sentido, também recorre a um modelo unicista. 
Retornando a Laqueur, constatamos que — apesar de a ciência oferecer dados que comprovariam que a diferença sexual é, em última palavra, de ordem biológica - a "diferença sexual contemporânea" não ficou mais estável, sociologicamente falando, do que a diferença sexual tal como concebida anteriormente: o modelo de dois sexos incomensuráveis é um produto cultural, assim como era o modelo do isomorfismo. Nenhum discurso sobre a diferença sexual triunfou.

Feita essa historicização do sexo, pode-se dizer que, em Freud, ambos os modelos são preservados, sem que em nenhum momento os processos biológicos fossem determinantes para cada um deles: o caráter universal do falo e o fato de ele ser masculino (isomorfismo), apesar das evidências anatômicas; e a posterior erogeneização da vagina graças à passagem pelo Édipo — percurso sem determinação biológica —, levando à constatação de mais um sexo (dimorfismo). Parece-nos que Lacan também procede da mesma forma ao preservar uma versão de ambos os modelos — "uma" função fálica e "duas" experiências de gozo incomensuráveis.

Le Gaufey (2007) também considera que a diferença sexual mescla duas possiblidades aparentemente heterogêneas: a oposição radical entre homem e mulher, duas categorias distintas; e outra que prega que só há uma categoria - o que diferenciaria homens e mulheres seria a gradação a partir de um terceiro e único elemento, indo do homem mais homem até a mulher mais mulher, passando por combinações intermediárias.

Nos "Três ensaios sobre a teoria da sexualidade" (1905), na ótica de Gaufey (2007), Freud afirma que o masculino e o feminino poderiam ser encarados em três vertentes: a da atividade e passividade; a do sentido biológico; e a do sentido sociológico. A primeira diz respeito ao caráter ativo da pulsão e passivo da meta (diferencialismo). A segunda seria definida nos termos de sêmen e óvulo; e a terceira poderia ser aferida a partir do comportamento cotidiano das pessoas (representação e fantasia). Em "Algumas consequências psíquicas da diferença anatômica entre os sexos", duas décadas depois, Freud ainda salienta a disposição bissexual presente em todos, sendo a masculinidade e a feminilidade puras elementos imprecisos. Se os aspectos sociológicos e psíquicos são mistos e incertos, hoje em dia já teríamos como argumentar que tal imprecisão não ocorre em nível orgânico: os cromossomos sexuais dos homens são XY e os da mulher, XX - determinantes para toda vindoura configuração fenotípica masculina ou feminina. Nesse sentido, os genes carregariam uma diferença sexual potencial irredutível. A genética seria o destino, então? 
Transexuais podem alterar seu corpo à vontade: nunca acederiam ao sexo oposto definido nesses termos, já que não se combate o imperativo genético. Contudo, a incerteza continua nos sujeitos.

Ainda segundo Le Gaufey (2007), por mais que hoje se possa cientificamente isolar dois pontos extremos, tensioná-los faz com que determinações sexuais escorram de um a outro. O problema se mantém: cada sexo possui uma substância singular que permite diferenciar um sexo do outro ou se trata da diferença sexual a ser definida a partir de um ponto comum, cada sexo sendo relativo ao outro? Duas substâncias separadas — o que prevê uma essência idêntica a si oposta a outra essência idêntica a si - que, fixadas, localizadas, afastam-se progressivamente? Ou o contrário: um relativo, tal como nossa experiência cotidiana atesta, psicológica e sociologicamente; e que, mais ou menos, racional ou intuitivamente, delimitaríamos um e outro sexo? Entidades ontologicamente distintas ou relativos infinitos? Com Lacan, consideramos que nem um nem outro: nem absoluto nem relativo. Aqui temos a chave da sexuação lacaniana que leva ao não todo e à não identidade - a coerção dos impasses da lógica é constante nesse terreno.

Safouan (2009) apresenta sua leitura sobre como diferenciar homens e mulheres no inconsciente. Para ele, se Freud teria concebido que se não se nasce mulher, mas se torna uma, o que não teria sido explicitamente tematizado por ele é que a mediação simbólica é aqui decisiva: "não se trata mais de ser ou se tornar mulher; trata-se de saber como um sujeito, qualquer que seja o seu sexo, venha a ter um desejo masculino ou feminino" (SAFOUAN, 2009, p. 13). Pensamos que, se o autor acerta em levar em conta o simbólico e o desejo, procede ao opor dois termos substancializados desejo homem e desejo mulher —, assim como a tão difundida dualidade 'gozo fálico' versus 'gozo suplementar', o que nos parece perigoso e incorreto. Como atesta Le Gaufey, tal procedimento se detém em um dualismo de caráter essencialista, do qual Lacan sempre quis se esquivar. Para Le Gaufey, o que interessava a Lacan era a relação sexual - "relação" no sentido matemático, quando na função dois termos se conectam de tal maneira a produzir um valor único. Como escrevê-la, se isso não ocorre entre homens e mulheres, já que a pulsão é sem objeto e nenhuma determinação natural faz com que homens e mulheres se aproximem?

Em "Diretrizes para um congresso da sexualidade feminina" (1960/1998), Lacan já havia apontado que, com a alienação ao Outro, não há natureza que determine a alteridade do sexo. $\mathrm{O}$ que não quer dizer que cada sexo tenha sua própria alteridade. $\mathrm{O}$ 
falo - já tratado como falo imaginário, simbólico, objeto metonímico, significante do desejo, significante que promove a significação, por exemplo (falo substantivo) —, nesse momento tardio da sexuação lacaniana, em que a dualidade homem e mulher está mais fortemente em pauta, tende a dar vez ao falo em seu caráter adjetivo, qualificando tanto uma função (função fálica) quanto um gozo (gozo fálico) comum a homens e mulheres. Contudo, seu status não é de mais ou menos: homens não tem mais ou menos acesso ao gozo fálico que as mulheres, nem vice-versa - tal como se diferenciavam homens e mulheres pela quantidade de calor. Dois sexos substancializados? Não. Se há um sexo, como haveria diferenciação, senão pela comparação de um relativo? Frente a essa questão, nos parece, ao lado de Le Gaufey (2007), Lacan se volta para a teoria dos números; e uma tese sobre homem e mulher é elaborada a partir do 'zero' e do 'um', que nunca chega a dois - mais que um, mas não dois: "uns".

Copjec (2012) também considera que o sexo, em Lacan, deve ser pensado a partir do número.

Se nos anos 1970, segundo Copjec (2012), a resistência do feminismo à psicanálise começa a diminuir na Inglaterra graças à publicação de Psychoanalysis and feminism, de Mitchell, e à profusão do trabalho do que veio a ser denominado "new french feminism" em solo norte americano, nos anos 80, o debate entre os campos se acirra. Se antes o foco era o status da diferença sexual e a sexualidade feminina, agora passa a ganhar terreno o que veio a ser denominado "gênero".

A diferença sexual, tal como postulada pela psicanálise, depende do Outro. Os estudos de gênero, segundo Copejc (2012, p. 35) atribuem a Lacan e ao estruturalismo a ideia de que o Outro é a-histórico, cujos efeitos são invariantes e imutáveis. Para que modificações ocorram, que supostamente apontariam para o caráter de um sujeito historicamente construído, há de se ir contra essa ideia pressuposta de diferença sexual em prol de uma tecnologia do gênero, uma maquinaria de práticas sociais, normas, relações de poder que construiriam as posições de gênero e as relações entre elas.

Contudo, Copjec (2012, p. 31) considera que, nessa passagem, algo se perdeu: não só a distinção sexual em si, mas, mais especificamente, o sexo — o próprio sexo foi posto de lado em favor de uma categoria neutra, 'gênero'. Priorizando práticas sexuais, atividades e performances, as teóricas de gênero, segundo Copjec (2012, p. 32), cessaram de se questionar sobre o que de fato o sexo é. Se nos anos 20 a estratégia feminista era o retorno a um biologismo realista para marcar a diferença, com os 
estudos de gêneros dos anos 80, o efeito foi o reverso: apagamento do corpo biológico e da diferença sexual, em favor de um sujeito sexuado somente a partir da tecnologia construtivista do gênero (COPJEC, 2012, p. 38). Outra estratégia mais recente teria sido a profusão do múltiplo:

Me parece que o futuro simbólico será um no qual a feminilidade terá múltiplas possibilidades [...] para além demanda de ser uma coisa, ou ter de ser condescendente a uma norma singular, uma norma determinada pelo falogocentrismo? Mas a base para se pensar a diferença sexual deve ser o binarismo para que a multiplicidade feminina emerja? Por que esta base não pode por si só se mover do binarismo em direção à multiplicidade? (BUTLER, 2004, p. 197; trad. nossa)

Assim, a noção de diferença sexual passou a ser problemática para os estudos de gênero porque tal termo faz, no idioma inglês, alusão direta a aspectos biológicos, parecendo implicar uma dualidade que pressupõe uma relação necessária entre os sexos, natural ou não. Falar em diferença sexual trazia novamente um ranço heterossexista ao debate. A diferença sexual ressucitava o binário num meio em que se clamava pelo múltiplo - múltiplos gêneros e múltiplos sexos; versão nominalista e individualista que produz sujeitos em particular, em defesa de uma suposta singularidade. Trata-se de uma boa estratégia? Essa proposta, supostamente revolucionária, em prol da diversidade infinita de identidades e modalidades de gozo não teria por base justamente, e paradoxalmente, negar a própria diferença, ou o processo pelo qual simplesmente um possa se diferenciar de outro? Zizek defende que sim: a produção da multiplicidade a partir do apagamento da diferença resulta na repetição do mesmo.

[...] como vamos combater a estabelecida rejeição pós-moderna da diferença sexual como uma "oposição binária"? Somos tentados a traçar um paralelo com a rejeição pós-moderna quanto à relevância do antagonismo de classe: antagonismo de classes não deve, de acordo com este ponto de vista, ser "essencializado" como o definitivo, ponto hermenêutico de referência cuja "expressão" ao qual todos os outros antagonismos podem ser reduzidos, pois hoje estamos testemunhando a prosperidade de novas, múltiplas subjetividades políticas (classe, étnica, gay, ecológica, feministas, religiosa), e a aliança entre elas é o efeito da aberta e absolutamente contingente luta hegemônica. No entanto, filósofos - de Alain Badiou a Fredric Jameson - têm apontado, em relação à celebração multiculturalista de hoje a respeito da diversidade de estilos de vida, como essa prosperidade das diferenças depende de um subjacente Um, ou seja, da destruição radical da Diferença, da lacuna antagônica. O mesmo vale para a 
estabelecida crítica pós-moderna da diferença sexual como uma "oposição binária" a ser desconstruída: "não existem apenas dois sexos, mas uma infinidade de sexos e identidades sexuais". Em todos esses casos, no momento em que introduzimos a "“multiplicidade próspera”", o que efetivamente nós declaramos é exatamente o oposto: a onipresença implícita do Mesmo. Em outras palavras, a noção de uma lacuna radical, antagônica que afeta todo o corpo social é obliterada. (ZIZEK in BARNARD; FINK 2002, p. 73; trad. nossa)

É como se a conjecturada limitação da diferença sexual tivesse de se render à multiplicidade supostamente libertadora dos gêneros ${ }^{31}$. Mas é realmente necessária a ideia de que o múltiplo é mais que dois ou que a diferença depende de dois? Daí considerarmos crucial acompanhar o percurso de Lacan pela teoria dos números e pensarmos homem e mulher a partir do Um.

O Um real deve ser pensado ao lado do universal que dispensa predicados ou atributos. O universal real, nos termos de Copjec (2012), retira dos seres individualizados qualquer predicado que possa ser universalmente aplicado nominalmente a eles. Esse Um, que marca a teoria do sexo em psicanálise, real, então se desvia do múltiplo predicativo que os estudos de gêneros bradam. O Um é indeterminado; paradoxalmente, é ele e mais que ele, ao mesmo tempo.

Neste sentido, fica evidente que o dois do sexo não se conforma com aquele número limitado que os nominalistas de hoje objetam. Diferença sexual não se concebe como uma redução do múltiplo a um múltiplo menor - somente dois — porque o 'dois' não é somente um 'um', um segundo 'um', adicionado ao primeiro. Ou: você está errado se pensa que $1+1$ te dará o 2 do sexo. (COPJEC, 2002, p. 34; trad. nossa)

Copjec, referindo-se ao trabalho de Derrida "Geschlecht: sexual difference, ontological difference", afirma:

O dois da diferença sexual deve ser pensado da seguinte forma. Não como dois uns separados e opostos, 'não como partição binária que se pode espontaneamente pensar como 'diferença sexual", uma sexualidade 'pré-dual', 'mais originária que a díade' ao qual a diferença sexual é comumente reduzida. Mais originário que a díade é o corte, a cisão, que não é uma cisão entre duas '(unidades) determinadas' [bestimmtheiten]. (COPJEC, 2002, p. 46; trad. nossa)

\footnotetext{
${ }^{31}$ Neste sentido, Levet (2014, pp. 34-5) considera que hoje em dia há toda uma facção composta por defensores da liberdade ilimitada e da indeterminação original, e que alegaria que a sociedade pretenderia monitorá-la , normalizá-la e puni-la. Contudo, a autora adverte para o risco de se confundir diferença dos sexos com inegalidade. Clamar por legitimação negando a diferença retiraria o sexo da cena.
} 
Ou seja, o Um não é aquilo que é cindido em dois, mas o que é constituído a partir da cisão. E nessa operação do corte, algo do Um é perdido. Para Copjec (2002, p. 46), o 'um' aponta para algo tanto além quanto aquém dele - e é nesse sentido que se deve pensar a afirmação de que só há uma libido. Trata-se do 'um' não idêntico a si, do ‘um' que é crítica da identidade.

O paradoxo trazido por Zenão a respeito de Aquiles e a tartaruga, tal como abordado por Lacan, serve para se pensar a diferença sexual não como duas entidades a serem contrapostas como humano versus animal ou como seres que tomam direções divergentes. Mesmo seus caminhos convergindo e se dirigindo ao mesmo limite, a tartaruga e Aquiles não se encontram - ele só pode ultrapassá-la. Nos termos de Ragland-Sullivan (2004, p. 93), também se referindo a Aquiles e a tartaruga, "eles sempre estarão em diferentes lugares um com relação ao outro, assim como os dois sexos".

Não há encontro, eles não fazem um. "Séries convergentes, que tendem a um limite comum sem encontro porque sempre permanece um número infinito de posições entre eles, cria-se uma condição positiva que tem um nome técnico: compacidade". O espaço compacto tende para um limite que funciona como impossibilidade, como uma falha de encontro; ao mesmo tempo, é um espaço de gozo. "O gozo emerge de um encontro com o impossível, ele depende de um limite" (COPJEC, 2012. p. 44) — isso faz eco ao obstáculo que há entre lado 'homem' e lado 'mulher' nas fórmulas da sexuação. Um obstáculo insolúvel é requerido na relação amorosa; a separação insolúvel que se impõe é o que incita o gozo, e não sua dissolução. As fórmulas da sexuação escreveriam uma não relação marcada por um obstáculo, um desencontro que passa no terreno que vai do 'zero' ao 'um'. Mas, antes de darmos prosseguimento a isso e ao enfoque deste "sexo compacto", vejamos alguns momentos em que esse tema da não relação já era anunciado por Lacan anteriormente.

\subsection{Não há relação sexual: antecedentes}

"[...] o discurso está aí como aquilo que permite a aposta do mais-de-gozar, [...] como aquilo que é proibido no discurso sexual. Não existe ato sexual. Já o expressei várias vezes e o abordo aqui por um outro ângulo."

— Jacques Lacan (1971/2009, p. 32) 
Em "Instância da letra no inconsciente ou a razão desde Freud" (1957/1998), Lacan apresenta a cena na qual dois irmãos, dentro de um trem, se defrontam com portas de banheiro da estação, acima das quais há os escritos "homem" e "mulher", respectivamente:

Um trem chega à estação. Numa cabine, um menino e uma menina, irmão e irmã, estão sentados um em frente do outro, do lado em que a vidraça dando para o exterior descortina a visão das construções da plataforma ao longo da qual o trem parou: "Olha!, diz o irmão, chegamos a Mulheres!; "Imbecil, responde a irmã, não está vendo que nós estamos em Homens?" (LACAN, 1957/1998, p. 503)

Lacan já parecia atento a certas questões: como um sujeito assume a imagem de homem ou mulher? Quando e como se constata que se "está em homem ou em mulher"? O outro é necessário para essa operação? Várias leituras podem ser empreendidas dessa passagem.

\section{HOMENS MULHERES}

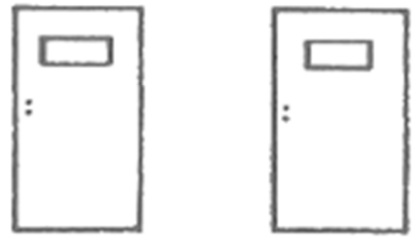

Os significantes são diferentes (homem e mulher), acima da barra, e se dão a ver; mas o que vem abaixo, o desenho das portas, o significado, está sob recalque. Anúncio de que o que diferencia homens e mulheres não são conteúdos do plano do sentido, mas os significantes.

Outra indicação da não relação, nesse mesmo texto:

[...] Homens e Mulheres serão para essas crianças duas pátrias para as quais a alma de cada uma puxará sua brasa divergente, e a respeito das quais lhes será tanto mais impossível fazer um pacto quanto, sendo elas em verdade a mesma, nenhum deles poderia ceder da primazia de uma sem atentar contra a glória da outra. (LACAN, 1957/1998, p. 504) 
Temos um dualismo sem trégua: homens e mulheres se encontrando numa situação até hierarquicamente implicada numa batalha em torno da terra do outro terras que, no fundo, são a mesma, pode-se considerar. De toda forma, evidenciam-se nessa cena que homem e mulher são posições opostas e dissimétricas, e que os pontos de vista são diferentes: o menino não vê a mulher do mesmo ponto que a menina vê o homem.

Os significantes sobre a barra dos banheiros permitem que se tome uma decisão de por onde entrar, mas os significados estão abaixo da barra, recalcados; os atributos não definem nada: nenhum significante, pelo menos na sua versão de shiftersemblante - que é da ordem do reconhecimento - determina um saber ou uma verdade sobre o sexo.

O falo pode ser considerado, nesse episódio dos banheiros, o único referente, daí as posições a partir das quais se é "visto" serem comensuráveis. Por sinal, cabe assinalar que entendemos que, mesmo com os desenvolvimentos do Seminário XVIII e o reposicionamento do falo na teoria, Lacan nunca deixou de creditar a ele seu protagonismo no que tange ao sexo - o falo passa a ser abordado a partir de outras perspectivas, dentro do universo do gozo sob a escrita lógica no estabelecimento da diferença sexual, sem nunca ser posto de lado.

Se antes, a partir do falo, se podia conceber uma relação entre os sexos - o homem e mulher extinguindo suas faltas para assumir o lugar do falo para outro outra perspectiva permite, agora, considerá-lo como justamente o que faz barreira.

Homem e mulher se relacionam com o falo como terceiro termo, Lacan (1971/2009, p. 132) precisa, e não meio-termo - não é que ele esteja entre os dois. Ou seja, homem e mulher não entram em contato direto, eles entram em contato com o falo, cada um a seu modo e com diferentes finalidades. Constatação já anunciada no Seminário X:

O campo abarcado pelo homem e pela mulher, no que poderíamos chamar, no sentido bíblico, de seu conhecimento um do outro, só coincide em que a zona a que seus desejos os levam, para que se atinjam, e na qual eles poderiam efetivamente superpor-se, caracteriza-se pela falta do que seria seu meio. $\mathrm{O}$ falo: é isso que, em cada um, quando ele é atingido, justamente o aliena do outro. Do homem, em seu desejo da onipotência fálica, a mulher certamente pode ser o símbolo, e justamente na medida em que não é mais a mulher. Quanto à mulher, está muito claro em toda parte que o que descobrimos com o termo Penisneid é que ela só pode tomar o falo pelo que ele não é - quer por $a$, o objeto, quer pelo pequeníssimo phi 
dela, que lhe dá apenas um gozo aproximado do que ela imagina do gozo do Outro, o qual ela decerto pode compartilhar por uma espécie de fantasia mental, mas só mediante uma aberração de seu próprio gozo. (LACAN, 1962-63/2005, p. 292)

O homem assume a onipotência fálica via mulher; esta se volta ao falo sob a forma de outros elementos que lhe permitiriam acesso a uma experiência muito particular.

Referindo-se a "referentes impossíveis de encontrar", Lacan (1971/2009, p. 44) trata macho e fêmea a partir dos caracteres chineses yang e yin. O significante evoca um referente, "sempre real”, afirma Lacan (1971/2009, p. 43); portanto, impossível de ser designado. Mais adiante, ainda a respeito dos princípios masculino e feminino, Lacan menciona que essa dualidade não pode ser mantida, justamente porque o falo está em jogo: "essa função do falo torna insustentável, doravante, a bipolaridade sexual; e insustentável de uma forma que literalmente volatiza o que acontece com o que se pode escrever dessa relação" (LACAN, 1971/2009, p. 62). Ou seja, não há dois polos que, se houvesse, permitiria que a relação sexual fosse escrita. Mais uma vez, o falo é justamente o que faz obstáculo a tal relação - em outros termos, é como se o falo derrocasse a bissexualidade freudiana, impondo um caráter negativo à diferença sexual, ao mesmo tempo em que permite pensar em duas experiências verdadeiras de gozo assimétricas. Nesse sentido, a existência da relação sexual que pode ser deduzida da ideia de bissexualidade é relegada ao campo da fantasia.

A relação sexual também pode ser pensada a partir do desejo e de seus objetos, tal como se apresenta no Seminário X. Se partirmos da consideração de que o que o homem tenderia a buscar do lado da mulher o que lhe falta e que diz respeito ao que ele não é, a mulher se dirigiria a ele atrás do que ela não tem. Mas ela não é objeto de desejo, de fato, do homem - ele se dirige ao objeto $a$. Já a respeito da mulher, o que ela visa é ao desejo do Outro, mas como meio de acesso. "No homem, o objeto é a condição do desejo. O gozo depende dessa questão. [...] Para a mulher, o desejo do Outro é o meio para que seu gozo tenha um objeto, digamos, conveniente" (LACAN, 1962-63/2005, p. 210). Claro que a mulher também tem que lidar com o objeto $a$, mas "é na dependência da demanda que o objeto $a$ se constitui para a mulher" (LACAN, 1962-63/2005, p. 221). Já no Seminário X, no quadro do desenvolvimento de sua teoria da fantasia, Lacan acrescenta elementos que vão além do desejo no seu entendimento de homem e mulher - acrescenta a noção de objeto $a$ e gozo, anunciando o real que se implica na relação sexual. 
Lacan questiona se, indo atrás do desejo dele, "o que ela encontra como resposta não foi a procura do desejo por ela, mas a procura de $a$, o objeto, o objeto verdadeiro, daquilo de que se trata no desejo, que não é o Outro, mas esse resto, a?" (LACAN, 1962-63/2005, p. 219). O objeto da busca do homem só diz respeito ao objeto a. Ou seja, o objeto da busca pelo qual o desejo dele é movido não tem nenhuma correspondência com o que falta para ela, ou melhor, com como a falta se apresenta nela. A não relação sexual, nesse prisma da fantasia, também revela um encontro faltoso, um equívoco de posições — não há uma fantasia masculina oposta à fantasia feminina que estabeleça algum tipo de complementariedade.

Tal dissimetria também se mostra no Seminário XVIII quando Lacan aponta que homem e mulher apresentariam formas distintas de desejo: "Desejo do homem, escrito $\Phi(a)$ [...] E o desejo da mulher se escreve A( $\varphi$ )" (LACAN, 1971/2009, p. 78). O desejo do homem põe em jogo o objeto $a$; já do lado da mulher, há a falta do Outro como motor - o que permite pensar em uma propulsão metonímica da fantasia no homem, e outra metafórica, na mulher.

A negativização do falo, no centro do desejo do homem, é determinante para a especificidade de sua relação objetal; já para a mulher, nem tanto, "uma vez que ela se revela superior no campo do gozo - uma vez que o vínculo com o nó do desejo é bem mais frouxo" (LACAN, 1962-63/2005, p. 202). A função fálica impõe limites mais rígidos ao homem; fiar-se assim ao desejo restringe seu campo de gozo. Já a mulher:

[...] fica sob a exigência e, eu diria, quase sob a condenação de só amar o Outro masculino num ponto situado além daquilo que a detém, também a ela, como desejo, e que é o falo. Esse além é almejado no amor. E um além, para dizê-lo corretamente, ora transverberado pela castração, ora transfigurado em termos de potência. O Outro masculino não é o Outro como um Outro a quem se trataria de estar unido. O gozo da mulher está nela mesma. Não se conjuga com o Outro. (LACAN, 1962-63/2005, p. 331)

A mulher se volta ao Outro para além daquilo que a conteria, o falo. E mais: não se trata de uma conjunção de união com esse Outro, o que supostamente declararia uma relação sexual, já que o gozo próprio à mulher escapa ao Outro.

Nessa perspectiva, no Seminário XVIII, Lacan salta da teoria dos discursos à sexuação; e, nos seminários seguintes, reforça a passagem do semblante ao gozo:

quando ousamos, como se faz todo dia, rotular nossos parceiros por seu sexo, é impressionante que tanto o homem quanto a mulher 
simulam [font semblant], cada qual, seu papel. Mas o importante, pelo menos quando se trata da função da fala, é que os polos sejam definidos, o do semblante e o do gozo. (LACAN, 1971-72/2012, p. 68)

Já no Seminário XVIII, Lacan revela o impacto da distinção desses dois polos. Quando o semblante fracassa, manca, o que vem à tona não é a verdade, mas justamente o real. A verdade só é falada desde o semblante, daí não se falar toda a verdade. Se o semblante homem tende a se restringir ao falo, o semblante do lado da mulher aponta para esse campo da verdade, além, que bordeja o real. E é como se A mulher fosse a figura maior dessa verdade que não pode ser totalmente abarcada. Ideia essa já presente em embrião no Seminário XI, sob os desenvolvimentos sobre a máscara e o olhar: "[...] é por intermédio da máscara que o masculino, o feminino, se encontram de maneira mais aguda, mais ardente" (LACAN, 1964/1998, p. 105). No nível do semblante, duplo, invólucro, "esse tigre de papel que ele dá a ver" (LACAN, 1964/1998, p. 104), o homem pode cogitar encontrar a mulher. Mas o sujeito vai além da captura imaginária do visível, ele joga com a máscara — aqui podendo ser associada ao anteparo à frente do objeto — , apontando para um mais além na dimensão do olhar, faceta privilegiada do objeto $a$ : “[...] o anteparo restabelece as coisas em seu estatuto real” (LACAN, 1964/1998, p. 105).

Homens e mulheres se colocam uns frente aos outros assumindo o lugar do semblante, mas desproporcionalmente. Os homens tendem a se restringir ao semblante e à problemática fálica, já a posição da mulher é outra: a mulher, além da sua própria vertente fálica, sempre em jogo, também adota o semblante na medida em que suporta a verdade para um homem. O homem está para a mulher de uma maneira dessimétrica à qual a mulher está para o homem. Temos aqui a não relação sexual no nível do semblante. Lacan afirma que o semblante é "assez phalle", "bastante falo", homófono de acéphale, acéfalo - se vertido predominantemente ao coito sexual, impede-se de "subordinar o chamado gozo sexual ao que, sub rosa, especificaria a escolha do homem e da mulher [...]" (LACAN, 1971/2009, p. 138). Ou seja, o semblante, no que veste o falo, não é o único elemento em jogo no contexto da escolha sexuada do ser falante; e, além do mais, potencializá-lo bloqueia o acesso à mulher.

Importante frisar que a teoria do gozo não deve ser encarada como substituto para a do semblante. Como pensamos, Lacan acrescenta, não descarta. No Seminário XX, Lacan ainda afirma que o gozo, assim como o amor, só é interpelado, perseguido, a partir de um semblante. Se, ao nos dirigirmos ao Outro, passamos 
necessariamente pelo objeto $a$, tal objeto é revestido de um semblante de ser - um semblante de ser é suposto a este $a$, imaginariamente. Emprestamos uma imagem ao $a$, i(a), e é ela que nos serve de alvo. Contudo, aqui estamos no nível imaginário e Lacan quer avançar ao real, para além dos revestimentos imaginários e da vertente do semblante restrita ao falicismo que configuram as relações objetais. O gozo, como abordá-lo? Já vimos que aquilo de que o discurso psicanalítico trata no que tange a homens e mulheres é, em ultima instância, a dissimetria, seja quanto à falta, o falo ou o desejo. Tal dissimetria, agora, na perspectiva do gozo, culminou no decreto "não há relação sexual" — que tem como terreno a lógica matemática.

$\mathrm{O}$ foco muda para além daquele em que homens e mulheres eram tomados como significantes. O gozo invade - e estamos, aqui, no campo do real. "É aí que se distingue o que pode nos vir a dizer o Real, [...] o Real não poderia inscrever-se senão por um impasse de formalização" (LACAN, 1972-73/2010, p. 186).

Quando se fala de escrita matemática, recorre-se a letras, e não a significantes - o que já acena para um além da linguagem, que, no entanto, não pode dispensá-la. Isso nos levaria em direção de uma verdade, que, como não toda, só pode ser semidita "[...] o verdadeiro dá testemunho de que, prevenindo-se como ele o faz, contra o imaginário, ele tem muito a ver com a $a$-natomia" (LACAN, 1972-73/2010, p. 189). Anatomia do objeto $a$, a letra $a$.

\subsection{Não há relação sexual: gozo e lógica}

"Eu não gostaria de terminar dando-lhes a ideia de que sei o que é o homem. Certamente há pessoas que precisam que eu lhes jogue esse verde. Posso jogá-lo para elas, afinal, porque isso não conota nenhuma espécie de promessa de progresso... ou pior. Posso dizer-lhes que, muito provavelmente, é uma relação completamente anômala e bizarra com seu próprio gozo que especifica essa espécie animal."

— Jacques Lacan (1971/2011, p. 67)

O gozo aponta para “outra satisfação" (LACAN, 1972-73/2010, p. 123): na medida em que somos seres falantes, nossas necessidades são deturpadas, contaminadas por essa outra satisfação que só pode ser atendida no nível do inconsciente. O gozo não decorre da descarga da tensão acumulada, guiada pelo princípio do prazer, mas de uma 
experiência de intensificação de certas tensões. "Onde é que isto habita, o gozo? Do que ele precisa? De um corpo. Para gozar, é preciso um corpo" (LACAN, 1971/2011, p. 28). O gozo requer um corpo, mas "a realidade é abordada com os aparelhos de gozo [...]: aparelho, não há outro senão a linguagem” (LACAN, 1972-73/2010, p. 127). Gozar leva em conta o corpo e suas diferentes zonas erógenas, assim como a maquinaria simbólica, o que permite que o gozo também esteja no coração da repetição do sintoma e convoque fantasias. No Seminário XX, Lacan afirma que só há gozo no corpo a corpo e só se goza tendo o corpo do outro como meio - goza-se em ser gozado, inclusive (LACAN, 197273/2010, p. 136).

Fica saliente a transição na obra lacaniana: "O significante é a causa do gozo”. De um lado, simbólico e linguística, de outro, real e lógica, mas sem abrir mão do que foi dito antes: "Sem o significante, como até mesmo abordar essa parte do corpo? Como, sem o significante, centrar esse algo que, do gozo, é a causa material?” (LACAN, 1972-73/2010, p. 80). E mais, o significante é o que frustra a disseminação avassaladora do gozo.

Contra a ideia de ser prevista pela tradição filosófica, e um suposto gozo ligado ao Ser supremo, Deus —, Lacan introduz o ser da significância. O ser da psicanálise é o ser falante que, como tal, é marcado por uma "pura perda" (LACAN, 1972-73/2010, p. 177), com a participação do objeto $a$.

"O gozo não conhece o Outro senão através desse resto, $a$ " (LACAN, 196263/2005, p. 192). O $a$ resiste a qualquer tentativa de assimilação ao significante, daí ser o índice do que, nessa esfera, se apresenta como perdido. Por mais que o sujeito se empenhe em fazer que esse gozo entre no lugar do Outro, que busque freneticamente o gozo, o sujeito se precipita enquanto desejante. Daí a angústia se situar entre o desejo e o gozo.

Lacan, para se contrapor a uma filosofia do ser, da essência no sentido de ousia, volta-se a uma topologia que contemple a ruptura. Na medida em que o ser em questão é atravessado pelo Outro, ele é um ser sexuado e está embebido em gozo - e, como tal, fraturado. O ser sexuado só pode ser tratado por "desvios em impasse, por essas demonstrações de impossibilidade lógica" (LACAN, 1972-73/2010, p. 24).

A experiência de gozo, ao contrário de outros eventos corporais apreensíveis pela ciência, não é comensurável. Estamos distantes da finalidade genital da pulsão freudiana: “[...] nada indica especialmente que seja para o parceiro do sexo oposto que se deve dirigir o gozo, caso este seja considerado, mesmo por um instante, como o guia 
da função de reprodução" (LACAN, 1971/2011, p. 33). Lacan vai, mais uma vez, afirmar que o sexual em psicanálise não se confunde com sexualidade ou práticas sexuais entre seres de sexos opostos com fins de reprodução; trazendo, agora, a noção de gozo e seu famoso aforismo para a discussão:

Vemo-nos diante do esfacelamento da ideia, digamos, de sexualidade. A sexualidade está, sem nenhuma dúvida, no centro de tudo que se passa no inconsciente. Mas está no centro por ser uma falta. Isso quer dizer que, no lugar de seja o que for que pudesse escrever-se da relação sexual como tal, surgem em substituição os impasses gerados pela função do gozo sexual. (LACAN, 1971/2011, pp. 33-4)

O falo "designa um certo significado, o significado de um certo significante completamente evanescente, pois, no que tange a definir o que se dá com o homem ou a mulher, a psicanálise nos mostra que isso é impossível" (LACAN, 1971/2011, p. 33). Trata-se então da indução de algo real, que ratifica que homem e mulher seja inarticuláveis, destinando-os à não relação:

De que estou falando? Ora, de nada além daquilo que é chamado, na linguagem corrente, de homens e mulheres. Não sabemos nada de real sobre esses homens e mulheres como tais. Não se trata de cães e cadelas. Trata-se daquilo que são realmente só aqueles que pertencem a cada um dos sexos a partir do ser falante. Aí não há sombra de psicologia. Homens e mulheres, isso é real. Porém, não somos capazes de articular na alíngua a mínima coisa que tenha a menor relação com o real. A psicanálise só faz repisar isso. É o que enuncio quando digo que não há relação sexual para os seres que falam. (LACAN, 1971/2011, p. 57)

Homens e mulheres podem ser distintos quanto à experiência de gozo. No campo do gozo, a relação sexual, no que compete ao ser falante, não se escreve - e os impasses gerados só podem ser tratados a partir dos recursos da lógica.

Lacan (1972-73/2010, p. 91) aponta que é preciso ler, “do que se lê para além do que vocês incitaram o sujeito dizer". O discurso analítico, isso se escreve. Para ler e escrever, precisamos de letras, que comporão fórmulas escritas a partir de produções lógico-matemáticas.

A linguagem não se reduz ao universo discursivo que levou ao discurso filosófico: ela apresenta muito mais recursos do que a ontologia que opera a partir do verbo copulativo 'ser'. Como se esquivar desse discurso, se não há realidade prédiscursiva, como afirma Lacan? (1972-73/2010, p. 98). Através de outro discurso, o 
analítico, cujo fundamento é a não relação sexual. O discurso analítico rompe com o caráter substancial que impregna a função do ser, produzindo falhas, descontinuidades e rupturas: do ser à letra, de l'être a lettre. Pretende-se ir em direção a um efeito que só pode ser acessado através da escrita, ideal da matemática, de acordo com Lacan (197273/2010, p. 114) - afinal de contas, como não há metalinguagem, um elemento anômalo na tentativa de abordar a linguagem é requerido.

Três letras: a, $\Phi$ e $S(A)$. "[...] o lugar Outro é simbolizado pela letra A" (LACAN, 1972-73/2010, p. 94) Contudo, este A é barrado, o que denota que no lugar de A, há uma falha ou buraco. $\mathrm{O}$ objeto $a$ vem a funcionar em relação a essa perda. $\mathrm{O}$ mesmo se dá com o falo, que a partir de sua designação com letra $\Phi$, abre-se uma nova dimensão, para além de sua vertente significante, tomado agora como função dentro da lógica. O significante foi introduzido pela linguística; a letra-escrita é tratada por Lacan a partir da lógica matemática. Mas como a relação sexual não existe, ela não pode ser escrita: “[...] não há relação sexual, eu volto a dizer isso [...], ela só se sustenta pelo escrito, e pelo escrito por isso: porque a relação sexual não pode se escrever" (LACAN, 1972-73/2010, p. 101).

Constata-se que "o que deveria resultar da linguagem, ou seja, a possibilidade da relação sexual se inscrever nela de algum modo, mostra de forma precisa, e na realidade, seu fracasso. Ela não inscritível” (LACAN, 1971/2009, p. 123). Inscrever aqui denota escrever-se também, mas com a sutileza de "fazer parte, entrar, registrar-se", como se a relação sexual não se filiasse à linguagem por não ter se escrito como participante dela, e não simplesmente que ela não é prevista na linguagem. A inscrição, se tivesse ocorrido, teria se dado pela escrita. "Se digo inscritível é porque o exigível para que haja função é que, pela linguagem, possa produzir-se algo que seja expressamente a escrita, como tal, da função [...], F(x)" (LACAN, 1971/2009, p. 122). A relação sexual não pode ser escrita - lógica falha aqui. Se o essencial de toda relação é a operação de implicação $(\mathrm{a} \rightarrow \mathrm{b})$, tal como Lacan considera no Seminário XVIII, a relação sexual não pode ser escrita na forma de $\hat{\sigma} \rightarrow q$, ou melhor, a escrita desta relação não contempla a relação entre o que é homem e o que é mulher, já que inexistente.

E mais: "tudo o que está escrito está condicionado de tal modo que parte do fato de que será para sempre impossível escrever como tal a relação sexual e que a escrita como tal é possível, ou seja, que há um certo efeito de discurso e que se chama a escrita" (LACAN, 1972-73/2010, p. 101). Dois pontos cruciais podem ser destacados 
aqui: a relação sexual não se escrever é atemporal, ahistórico — "o real de que não há relação sexual se depositou ao longo das eras", cita Bárbara Cassin (2013, p. 33) uma passagem de $O$ aturdito. A não relação diz respeito a pontos de sem saída entre simbólico e o real desde sempre, o que muda é a forma com que se lida com tal impossibilidade. Tentativas foram feitas na forma do amor cortês na história ocidental ou tal como Van Gulik prescreve em A vida sexual da antiga China, quando se apostava que um gozo da polaridade sexual seria possível, segundo Lacan (1971-72/2012, p. 69).

Talvez tenha havido algum lugar, talvez até ainda existam lugares em que se passe entre o homem e a mulher essa conjunção harmoniosa que os faria ficarem no sétimo céu. Mas, coisa muito curiosa, trata-se sempre de lugares em que é realmente, seriamente preciso dizer a senha para entrar. Nunca se ouve falar deles, a não ser de fora. (LACAN, 1971-72/2012, p. 69)

Em suma, cada cultura tenderia a lidar de uma forma específica com a não relação sexual.

Segundo ponto: a escrita é um pressuposto que sustenta o discurso. 'Homens' e 'mulheres' são significantes e um procura o outro a título de significante e do que se situa a partir do discurso; mas, quanto à mulher, "há sempre alguma coisa nela que escapa do discurso" (LACAN, 1972-73/2010, p. 99). Outro impasse.

Não há metalinguagem. "Nesse próprio fracasso, entretanto, pode-se denunciar o que se passa com a articulação que tem, precisamente, a mais estreita relação com o funcionamento da linguagem, ou seja, a seguinte articulação: a relação sexual não pode ser escrita" (LACAN, 1971/2009, p. 126). O que nos faz considerar que o discurso, se estranho à relação sexual, por outro lado, faz discurso em torno de sua impossibilidade.

Além de não haver metalinguagem, para que a própria linguagem entre em funcionamento, a relação sexual deve não ser escrita. Mais interessante ainda é a afirmação: "a linguagem [...] tem seu campo reservado na hiância da relação sexual, tal como o falo a deixa aberta" (LACAN, 1971/2009, p. 63).

Tomemos como exemplo a sequência proposicional "Todo homem é bom; alguns animais são homens; logo, alguns animais são bons" (LACAN, 1971/2009, p. 127). Tal dedução não faz sentido, se nos atemos ao enunciado, já que animais não são homens. Contudo, e é isso o que interessa Lacan, tal equivalência só pode ser declarada se for passível de ser escrita, enquanto letra — o conteúdo não é elevado em conta, mas 
a relação. Importante frisar isso porque, na função $\mathrm{F}(\mathrm{x})$, o x é uma variável, podendo ser qualquer coisa - homem, mulher, animal, abajur. A proposição deve ser examinada como verdadeira ou falsa na medida em que respeita, ou não, a função à qual está submetida, por critérios lógicos, e não na medida em que faz sentido. E é nessa perspectiva que Lacan vai tratar da relação sexual e o papel do falo nela. Lacan toma o $\mathrm{x}$ como o falo - no caso, terceiro termo, e não meio-termo - a se infiltrar entre o homem e a mulher. Não à toa, um texto célebre de Lacan sobre o tema se chama "A significação do falo" (1966/1998). Significação, Bedeutung, deriva da lógica de Frege. Esse termo também pode significar denotação, o que é preciso para que uma fala denote alguma coisa. Significação do falo: é uma significação que o falo tem (genitivo subjetivo), ou o falo é submetido à significação (genitivo objetivo)? Segundo Lacan, "o falo denota o poder de significação" (LACAN, 1971-72/2012, p. 54): é o que permite que um significante possa ser atrelado a um significado; é aquilo pelo qual a linguagem significa.

Rabinovich, em trabalho dedicado justamente ao estudo desse texto de Lacan, relaciona a diferença significante à diferença sexual: "aqui a diferença intervém como metonímia da diferença sexual [...]. A diferença significante substitui, assim, a diferença sexual, a especificidade perdida do biológico, perda que é consequência da captura do corpo do ser falante pelo significante" (RABINOVICH, 1995, p. 23).

No ser humano, a cópula sexual biológica, instintiva, falha. O que supriria tal falta seria a cópula lógica: "O falo suprirá o que o significante faz a sexualidade humana perder de natural, suprirá enquanto marca e, ao mesmo tempo, como cópula, como o que faz laço lógico entre os sexos" (RABINOVICH, 1995, p. 41). O falo seria como que a marca tipográfica dessa cópula lógica.

Significação - "e só existe uma, a significação do falo" (LACAN, 197172/2009, p. 159). Lacan aponta a importância de se diferenciar Sinn e Bedeutung; e, para tanto, "sem uma referência lógica, que obviamente não pode bastar, à lógica clássica, aristotélica, é impossível encontrar o ponto correto nas questões que proponho" (LACAN, 1971-72/2009, p. 159). Exemplo: Vênus = estrela da manhã. Em certa medida, podem ser substituídas, tendo o mesmo sentido; em outra, não, pois são nomes diferentes. Se o nome é aquilo a que se chama a falar, por mais que se chame o falo, “ele continuará a não dizer nada" (LACAN, 1971-72/2009, p. 160). No nosso caso, o argumento da função assume a significação de homem ou de mulher. 
"O que ele introduz não são dois termos que se definem pelo masculino e pelo feminino, mas a escolha que há entre termos de natureza e função muito diferentes, que se chamam ser e ter" (LACAN, 1971/2009, p. 63). Importa o falo como função nesse caso, diferentes funções. Ser estaria do lado da relação sexual, função matemática (todo x é y, implica atribuição). Ter estaria do lado da lei sexual, campo do desejo e da proibição, diferencia Lacan; e não que "ser o falo" seja sinônimo de mulher ou feminilidade ou "ter o falo" de homem ou masculino - trata-se tanto de atribuição lógica (relação sexual) quanto do campo do desejo. Ou seja, a antiga fórmula 'ser o falo $=$ mulher' $\mathrm{e}$ 'ter $\mathrm{o}$ falo $=$ homem' passa a ser vista em outra perspectiva, também $-\mathrm{o}$ que pode ser abarcado pela ordem do desejo e pelo domínio do gozo, linguística e lógica, com o falo em ambos os terrenos. $\mathrm{O}$ falo, inclusive, é fator que regula o gozo: ordena, aproxima e afasta o sujeito dessa experiência. Há uma passagem, então; e essa lei sexual, que pretende articular a relação de cada sexo com o gozo, será escrita agora a partir das proposições universais e particulares afirmativas e negativas.

Tal como já apontamos, a diferença sexual pode ser abordada a partir da heterogeneidade do desejo e do mapa fantasístico em 'homem' e 'mulher'. Agora, tomando a lógica como referência, a dissimetria entre os sexos se dá a partir da lógica interna a cada um.

Já no Seminário XVIII, Lacan começa a discorrer sobre os fundamentos da lógica aristotélica que sustentam sua teoria da sexuação. Parte-se das categorias proposicionais: universal afirmativa, particular negativa, universal negativa e particular afirmativa.

Posteriormente, acrescenta elementos da lógica matemática regida pela quantificação: derivada da lógica dos predicados, depreende-se a quantificação universal (para todo, $\forall$ ) e a quantificação existencial (existe, $\exists$, algun(s)), atrelada ao $\operatorname{particular}^{32}$. A importância de se pensar os quantificadores lógicos 'todos' e 'algum' se desnuda em Lacan no enunciado "O homem é uma função fálica na qualidade de todo homem" (LACAN, 1971/2009, p. 132). As articulações matemáticas, a partir da lógica, passam a ser relacionadas ao valor de verdade. As proposições são avaliadas como verdadeiras ou falsas. Neste contexto, costuma-se ponderar se somente a proposição

\footnotetext{
${ }^{32}$ Não pretendemos, aqui, fazer um acompanhamento passo a passo dos progressos, revisões e correções que Lacan fez da lógica para a composição da sua teoria da sexuação ao longo dos Seminários XVIII e XIX, mas discorrer sobre seus alicerces já prismados pela nossa interpretação e interesse de pesquisa. Para o "passo-a-passo" da lógica que rege a sexuação, indicamos o vigoroso trabalho de Guy Le Gaufey (2007).
} 
verdadeira poderia fundar outra proposição verdadeira — se tal fundação também competir à proposição falsa, o princípio da não contradição que rege tal análise deveria ser revisto. Isso vai interessar a Lacan, pois se todo x $\Phi$ x (universal afirmativa), como poderia existir um $\mathrm{x}$ que negasse tal proposição universal? Teríamos aqui uma contradição. Lacan contesta o princípio da não contradição aristotélica em sua incursão na lógica. Cabe pontuar que já é aqui, nesse mesmo Seminário XVIII (LACAN, 1971/2009, p. 131), que Lacan implementa a novidade que é negar o quantificador universal, fundamento do que pode ser denominado como sua inovadora "lógica do não todo".

A essas formalizações, Lacan adiciona operadores da lógica modal: necessário, possível, impossível e contingente. Então, parte-se da lógica proposicional aristotélica, adicionam-se os elementos da lógica dos quantificadores e da lógica modal, culminado no reposicionamento do princípio da não contradição, marca da posição masculina, assim como a negação do quantificador universal, uma das marcas da posição feminina.

E é nesse contexto que Lacan (1971/2009, p. 104) anuncia: "Pois bem, justamente em torno disso que se articula o que acontece com a relação sexual”. Aqui, a nosso ver, Lacan revela qual será seu foco de interesse a partir de então: tratar o aforismo "A relação sexual não existe" a partir da lógica e depurar suas consequências, que culminarão tanto na construção (ou na escrita) das fórmulas da sexuação apresentadas de forma definitiva no Seminário XX - quanto na persistente implicação, feita por ele, de tal aforismo no discurso do psicanalista. No Seminário XIX, ao discorrer sobre as proposições existenciais do lado 'mulher' e o lado 'homem' da tábua da sexuação, Lacan (1971-72/2012, p. 133) afirma: "Nas duas superiores destas quatro fórmulas que reescrevi no quadro [...] tento fixar o que vem suprir o que chamei de impossibilidade de escrever o que vem a ser a relação sexual”. As fórmulas da sexuação teriam esta finalidade principal, tratar da não relação sexual, e não seriam a escrita de uma suposta essência de homem e mulher — não pretendem definir homem ou mulher, sob quaisquer critérios (biológicos, de gênero ou quanto à escolha de objeto), mas focam uma não relação. Outro ponto: a relação sexual impõe um limite aos discursos, cabendo só a um deles enfrentar o indecidível que constitui esse aforismo. Se existe um discurso que mira a não relação sexual, esse discurso é o discurso do psicanalista: “[...] o ponto mais importante que somente o discurso analítico revela, ou seja, o que só pode se articular graças a toda construção do discurso analítico: é que muito precisamente 
não há relação sexual" (LACAN, 1972-73/2010, p. 101) - a associação entre estes dois, tal aforismo e tal modalidade de discurso, é exaustiva nos Seminários XIX e XX.

Mais uma vez, vejamos o avanço de Lacan com relação ao Seminário XVII. Insistimos nessa passagem porque nos parece que ela não foi examinada pelo feminismo que se voltou a Lacan. Há algo para além do que o discurso sexual, fálico, comporta. Contudo, "o mais-de-gozar só se normaliza por uma relação que se estabelece com o gozo sexual, exceto que esse gozo só se formula, só se articula a partir do falo como seu significante" (LACAN, 1971/2009, p. 32). O falo não é designado como falta de significante ou significante da falta, mas atrelado ao "gozo sexual como coordenado com um semblante, como solidária a um semblante" (LACAN, 1971/2009, pp. 32-3). O falo não perde seu status, mas algo é acrescentado. Outro exemplo de avanço: "O pênis, ele sim, pauta-se pela lei, isto é, pelo desejo, isto é, pelo mais-de-gozar [...]" (LACAN, 1971/2009, p. 65). Estamos passando da lei da metonímia do desejo para o campo do gozo. Outra forma disso se mostrar é na grafia "acoisa" no Seminário XVIII, que Lacan adota várias vezes: da Coisa, das Ding, do Seminário VII, conceito grafado em maiúscula, passamos para sua escrita acoplada a este "a", como forma de revelar seu caráter de ausência sem anulação: acoisa ocupa um lugar ao manter-se ausente. Como tal, não pode ser mostrada, só cabe ser demonstrada. Pode-se também dizer que a escrita à qual Lacan se refere visaria escrever acoisa. Esse avanço do desejo ao gozo, do falo ao objeto $a$, é correlativo da reconsideração da Lacan a respeito dos operadores em jogo na diferença sexual e de um elemento que apontaria para uma especificidade da mulher. Esse passo é correlato da retomada dos mitos fundadores da psicanálise no Seminário XVIII e impulsiona outra passagem decisiva: “é preciso inverter: em lugar de 'um' significante que se interroga, interrogar o significante Um [...]” (LACAN, 197273/2010, p. 75), a partir do que Lacan esmiúça seu Há-do-Um [Y a d' l’Un].

No Seminário XVIII Lacan retoma, para contrapô-los, os mitos fundadores de Édipo e de Totem e Tabu: "do menino, da mãe ou do trágico da passagem do pai para o filho - passagem do quê, senão do falo? - de tudo isso que serve de estofo para o primeiro mito, não há nenhum vestígio no segundo". Não são versões do mesmo mito. Enquanto o primeiro gira em torno do conflito incestuoso, o segundo ilumina outro ponto. Neste se destaca, principalmente, o pai da horda: "o pai goza de todas as mulheres, até ser abatido pelos filhos [...], de modo que nenhum deles sucede ao pai em sua glutonaria de gozo" (LACAN, 1971/2009, p. 148). Esse pai é caracterizado como hommoizin, ao menos um que diz 'não', escapando da castração, impondo que esta 
recaia sobre todos os homens, decretando uma barreira, condenando-os à eterna "esperança" de reabsorção daquela parcela perdida de gozo. Sobre a leitura desse mito por Lacan:

Isso tem ainda mais interesse na medida em que ali não se trata de gênese nem de história, nem de seja o que for que se assemelhe a um acontecimento, embora pareça, em certos momentos, que teria sido anunciado por Freud nessa categoria. Aquilo que nos é apresentado como anterior a toda história não poderia ser um acontecimento. Não há acontecimento senão a partir do que se conota em algo que se enuncia. Não se trata de acontecimento, mas de estrutura. O mito de Totem e tabu foi feito, de maneira mais patente, para podermos falar de todo homem como estando sujeito à castração. (LACAN, 197172/2012, p. 195)

Estrutura lógica, então - ao menos um —, e não antropologia. Se no Édipo se trata da origem do desejo, circulação do falo, identificação sexual e escolha de objeto; em Totem e Tabu, do gozo. A retomada desses mitos centrais permitiu a elaboração de outros elementos da sexuação lacaniana: “[...] Totem e tabu foi feito exatamente para nos apontar que é impossível dizer $A$ mulher" (LACAN, 1971/2009, p. 99), já que é impossível se tomar todas as mulheres, a não ser em mito.

Esse ao menos um que nega, ao mesmo tempo une "todas as mulheres". Mas Lacan propõe uma modificação nisso: "Ele as une, com certeza, mas não todas" (LACAN, 1971-72/2012, p. 206).

Totem e tabu foi o que se pôde fazer para dar ideia dessa condição lógica, da abordagem individual que a mulher pode fazer do homem. Por si só, já não é extraordinário que o enunciado desse mito não pareça ridículo, ou seja, a história do mito original que usufruiria de todas as mulheres, o que não é possível, não simplesmente por estar claro que temos nossos limites, mas porque não existe um todo das mulheres. (LACAN, 1971-72/2012, p. 44)

Ou seja, o mito não é anterior à articulação lógica ${ }^{33}$. Como acredita Safouan (2009, p. 77), a passagem do pai da horda para o 'ao menos um' teve como finalidade esvaziar o caráter imaginário do Édipo - e das figuras de pai nas instituições — em prol do uso dos fundamentos da lógica em psicanálise. Além disso, não há como

\footnotetext{
${ }^{33}$ Comentadores apresentam visões diferentes sobre esse ponto. Soler aponta que, nas fórmulas da sexuação, "Lacan teria refutado o Édipo como mito e comédia do 'Pai-Orango, do peronte Otango, para reduzi-lo unicamente à lógica da castração" (SOLER, 2005, p. 28). Ao contrário de David-Ménard, que defende certo aspecto sociologizado: “A interpretação das fórmulas do lado 'homem' é então a seguinte: somente as aventuras particularizantes de seu desejo por mulheres que encarnam o que, dele mesmo, não pode se refletir no simbólico, fazem do homem, um homem" (SOLER, 1998, p. 106).
} 
conceber um todo da mulher, que seria de usufruto do Pai imaginarizado nesse 'ao menos um': mesmo a denotação de homem estando atrelada ao todos frente à função fálica, existe um ‘ao menos um’ para quem a verdade dessa denotação não se aplica, ou seja, a função fálica seria subvertida nesse nível - estamos aqui numa lógica que incorpora o princípio da contradição como um caso particular. Na citação acima também aparece "todas as mulheres" - proposição fundamental, na medida em que Lacan pretende refutar sua universalidade.

O estatuto necessário desse 'ao menos um' possibilita a existência do homem como valor sexual. Tal necessidade surge da suposição de uma inexistência, "não no sentido de não ter existência, mas a de só ser existência a partir do símbolo que a faz inexistente, e que, ele sim, existe" (LACAN, 1971-72/2012, p. 50). Essa inexistência não é o nada. Esse símbolo existe como o número zero - e aqui Lacan recorre ao estatuto de número em Frege.

A necessidade lógica supõe a inexistência como tal: em Frege, o número 1 pressupõe o conceito de inexistência, conceito esse que não é conceito de nada, mas de um conceito cujo número é igual a zero e que poderia ser definido a partir do argumento $x$ diferente de $x$. O 'zero' é tratado como conceito e número: o 'zero' é o número cujo conceito é vazio. Para os nossos fins, interessa a constatação de que é só através da necessidade lógica do fundamento da inexistência que se chega à gênese do 1 . O que existe, o que se transfere do 'zero' para o 1? Isso é que nos parece ter, de fato, interessado Lacan. A questão é como inserir essa elaboração na discussão que diz respeito a homem e mulher.

Podemos dizer que o sexo, em psicanálise, é encarado como justamente o que os discursos desconhecem. Se se considera a vertente do gozo como prevalecente, se o que define, em última instância, em psicanálise, homem e mulher é uma prática de gozo, "desta forma ficariam cortadas as amarras para uma eventual teoria psicanalítica do gênero? Ou, então, teríamos de definir gênero sem associá-lo a uma prática de gozo?” (DUNKER, 2016, p. 182). Por fim, este nos parece ser o avanço que Lacan propõe no tratamento de 'homem' e 'mulher': "não há relação sexual”, aforismo a ser abordado sob instrumentos da lógica e da teoria dos números, ao contemplar formas distintas de posicionamento frente à função fálica e diferentes modos de gozo. 


\subsection{A relação sexual falha de duas maneiras}

A relação sexual não existe, ela não pode ser escrita. Mas a não relação poderia ser escrita? “[...] essa não relação, se assim posso me exprimir, é preciso escrevê-la. A todo custo, é preciso escrevê-la. Refiro-me a escrever a outra relação, a que tampona, a que barra a possibilidade de escrever a primeira" (LACAN, 197172/2012, p. 30). Nessa passagem, Lacan incita a que se escreva a não relação; mas como, se a ausência da relação sexual seria "única parte do Real que não pode vir a se formar por letras" (LACAN, 1972-73/2010, p. 119)?

Existiriam duas maneiras de lidar com este 'não há relação sexual', duas formas de falhar a relação sexual, ou duas formas distintas de nos relacionarmos com esse aforismo: a masculina e a feminina. Segundo Lacan, “[...)] o universo é onde dizer tudo tem êxito" [...] Tem êxito em quê? [...] tem êxito em fazer malograr a relação sexual, do modo masculino" (LACAN, 1972-73/2010, p. 130). A falha da relação sexual no homem passa pelo seu tratamento do universal. E da mulher, também, justamente ao não constituir universal:

Há duas maneiras de fazer malograr essa história, a relação sexual. [...] Que haja, pois, a maneira masculina de girar em torno e depois a outra, que eu não designo de outro modo, porque é isso que estou elaborando este ano, ou seja, como, do modo feminino, isso se elabora pelo não todo. (LACAN, 1972-73/2010, p. 130)

E por que não há relação sexual? "[...] se há um ponto de onde isso poderia se esclarecer, pois justamente há algo ali que não se junta, é justamente do lado das mulheres, na medida em que se trata da elaboração do "não todo"' (LACAN, 197273/2010, p. 131). Esse não todo impede que 'algo se junte' — impeditivo de universalidade - ao universal constituído do lado 'homem'.

Não há relação sexual, ela falha de duas maneiras; e mais: essas duas maneiras de falhar, cada uma a seu modo, não estabelecem entre si nenhuma relação. $O$ que se perpetua não se escrevendo. Isso pode ser tratado a partir dos operadores da lógica modal.

Temos quatro categorias modais: necessário, possível, impossível e contingente. O necessário é o que não cessa de se escrever; o impossível é o que não cessa de não se escrever; possível é o que cessa de se escrever; o contingente é o que cessa de não se escrever. Lacan aqui não opõe necessário a contingente, como seria o esperado, mas necessário e impossível: “o necessário está conjugado ao impossível, e 
esse 'não cessa de não se escrever' é sua articulação" (LACAN, 1972-73/2010, p. 133). O impossível é que o não pode ser escrito de forma alguma, correlato da relação sexual: a relação sexual não cessa de não se escrever. Contudo, a contingência pode 'atuar', correspondendo à necessidade da função fálica, fazendo com que cesse esse 'não cessa' do impossível, levando a cessar de não se escrever, contingencialmente, como se daria "no regime de um encontro fortuito" (LACAN, 1972-73/2010, p. 189), no amor.

$\mathrm{Na}$ sua relação com o sexo, o real como impossível se traduz na impossibilidade da relação sexual enquanto ausência de sentido:

Assim, o impossível, logo, o real, está correlacionado com ab-senso, nomeadamente a ausência de toda relação, o que quer dizer a ausência de todo sentido sexual. [...] Mas a ausência de sentido quer dizer positivamente senso ab-sexo, isto é, finalmente, o real como tendo essa ausência de sentido que é que não há relação, neste caso, relação sexual [...]. (BADIOU; CASSIN, 2010/2013, pp. 67-8)

Ausência de sentido marcada pelo real que faz com que a não relação sexual se imponha, frente a qual homem e mulher se posicionam de forma heterogênea - é aqui que localizamos o ponto mais agudo da incondicionalidade da diferença dos sexos.

\subsection{A mulher não existe: tensões}

[...] o que falta a Freud aí, como sabemos, é o que falta em seu discurso. É aquilo que, para ele, sempre se manteve em estado de pergunta: o que quer uma mulher? [...] É aí que está o ponto cego. Freud quer que ela lhe diga tudo, a mulher.

— Jacques Lacan (1962-63/2005, pp. 144-5)

O aforismo lacaniano "A mulher não existe" é correlativo da inexistência da relação sexual, dai consideramos importante nos determos também nele. Além do mais, seu enunciado provocativo foi recebido de maneiras distintas pelo meio feminista - do entusiasmo ao rechaço.

Inicialmente traremos várias passagens de Lacan a respeito da mulher. Nossa intenção é demonstrar o quanto o psicanalista francês pretendia tratar das especificidades do feminino para além da mirada do homem. 
Lacan reconhece e denuncia a depreciação dos ditos a respeito das mulheres ao longo da história: "A gente diz a mulher [on la dit-femmel diffâme]. O que de mais notável restou das mulheres na história é, propriamente falando, tudo o que se pode dizer delas de infamante" (LACAN, 1972-73/2010, p. 176).

$\mathrm{Na}$ tradição da psicanálise, a histérica foi tida como um sujeito que pretende "bancar o homem", identificando-se ao falo ou atestando uma impossibilidade de aceder a uma experiência de gozo não fálico. Mas a experiência do feminino aponta justamente para o não idêntico a si, este que a histeria tenderia a falicamente neutralizar. Tal descrição da histérica toma como referência central o falo, que, se equacionado ao masculino, pode levar à crítica de que a visão psicanalítica da histeria é masculinamente falocêntrica. $\mathrm{O}$ homem no centro, como apontava Irigaray. Mas histeria não é sinónimo de feminilidade - pelo contrário, seria seu apagamento. Lacan se esforça em separar a posição da mulher da histeria. Nesse sentido, Lacan estaria se propondo a remediar esse ‘erro', ver a mulher a partir de outro olhar, para além da formatação fantasística masculina a ela imposta.

Há algo de essencial no que trago como complemento ao que foi bem visto pelas vias que isso esclareceria ver, o que foi visto só do lado do homem. Ou seja, que aquilo com que o homem tinha a ver, era com o objeto pequeno $a$, que toda sua realização dessa relação sexual conduzia ao fantasma [...]. (LACAN, 1972-73/2010, p. 178)

Em outro momento, Lacan aponta o limite de Freud sobre a mulher e todo o campo que foi negligenciado:

O que abordo esse ano é muito precisamente aquilo que a teoria, a articulação teórica de Freud, e muito precisamente o que em Freud é deixado de lado expressamente, de uma maneira confessada, o was will das Weib?, "o que quer a mulher?" que a teoria de Freud, como tal, expressamente confessa ignorar. Freud afirma que só há libido masculina. O que dizer disso, senão que um campo que, de todo modo, não é sem importância (se acha assim ignorado)? (LACAN, 1972-73/2010, p. 170)

Lacan adverte contra a exclusividade da castração na orientação analítica. Há de não se restringir ao Pai para ir em direção à mulher.

Quando eles [os analistas] não saem daí, não saem do que se passa do lado do Pai, isso tem uma causa muito precisa: é que seria preciso o sujeito admitir que a essência da mulher não está na castração [...] É a partir do momento em que é pelo impossível como causa que a mulher 
não está ligada essencialmente à castração, é a partir daí que o acesso à mulher é possível, em sua indeterminação. (LACAN, 1971-72/2012, pp. $19 ; 45)$

Aqui não estamos no registro do falo. Essa parcela de real que a mulher pode acessar, "impossível como causa", abre o campo do gozo, já previsto no Seminário $\mathrm{X}:$

O desejo da mulher é ditado pela questão, também para ela, de seu gozo. Que do gozo ela não apenas está muito mais perto que o homem, mas é duplamente dominada por ele, é o que a teoria analítica nos diz desde sempre. (LACAN, 1962-63/2005, p. 289)

Duplicidade essa ratificada no Seminário XIX: "Se a mulher não é toda, é porque o seu gozo é duplo" (LACAN, 1971-72/2012, p. 101). Aqui, sim, relacionando o gozo dito propriamente feminino - além do gozo fálico, também acessível a ela — à especificidade lógica que o retrataria.

Estamos no campo do gozo feminino marcado pela indeterminação, uma experiência de não identidade. A mulher não existe. Não se nasce mulher, nem se torna mulher. Não há substância; se ela existisse, talvez a questão de o que é a mulher não tivesse surgido:

Tornar-se uma mulher e interrogar-se sobre o que é uma mulher são duas coisas essencialmente diferentes. Eu direi mesmo mais - é porque não nos tornamos assim que nos interrogamos, e até certo ponto, interrogar-se é o contrário do tornar-se. A metafísica de sua posição é o subterfúgio imposto à realização subjetiva da mulher. Sua posição é essencialmente problemática, e até certo ponto inassimilável. (LACAN, 1955-56/1988, p. 204)

Curiosamente, se hoje em dia estamos em meio à proposta de fluidez de gênero, há quem pregue, como a feminista e filósofa francesa Sylviane Agacinski (2012), que o último fator a distinguir homem e mulher seria a capacidade de procriação. Tal tese, já classicamente combatida por Badinter, ressurge na pena de Agacinski, que defende essa vertente de um feminismo essencialista que se sustenta na maternidade como ponto irredutível da diferença sexual - o que faz pensar no que aconteceria então com as mulheres impossibilitadas no que se refere à fecundação ou à procriação, ou mesmo que não as desejam: não seriam mulheres ou o seriam menos? Agacinski, segundo Leguil (2015, p. 121) propõe às mulheres que retornem a seus corpos num assujeitamento à procriação obrigatória. Justamente o que Lacan quis evitar. Mas como tratar da mulher, enquanto inexistente, sem fazê-la desaparecer? "A 
feminilidade [...] excede as normas, não somente sociais, mas mesmo as normas da lógica" (LEGUIL, 2015, p. 125). Lacan quer desatrelar mulher dos atributos inferiorizantes que lhe foram imputados, sem fazer com que ela suma, preservando seu caráter subversivo também quando recorre à lógica — ou para formalizar logicamente a transgressão intrínseca à posição feminina.

'A mulher não existe' quer dizer que não ela não deve ser tomada substancialmente e, como veremos à frente, que não existe o conjunto da mulher. Contudo, tal aforismo, para alguns, "seria como mais uma estratégia de silenciamento e incitação do falar feminino numa nova versão da produção e expropriação de sua identidade" (DUNKER, 2011, p. 514). Nas palavras de Ragland- Sullivan (2004, p. 174), "a insistência de Lacan na não essência do feminino, não significante para Mulher qua Mulher no inconsciente, foi desvirtuada pelas feministas a ponto de considerá-lo um falocrata que desdenha as mulheres".

Por outro lado, Saez considera que a posição de Lacan de decretar uma não identidade não denigre a mulher - isso cabe à cultura, não ao lacanismo:

Os problemas de identidade são paradoxais e é impossível reduzi-los a equações biológicas mais generalizadas: "sexo/gênero/prazer". Lacan demonstrou que as estruturas podem reconstruir-se, mas não é possível liberar-se delas completamente. A linguagem da sexualidade e do desejo só podem ser perseguidas através de seus caminhos paradoxais. Se A mulher (com maiúscula) é impossível de identificar porque não existe, isso não impede que exista a condição feminina, $\mathrm{e}$ as diferentes misérias que a sociedade submeteu as mulheres. Mas se assumimos a tese de Lacan, um sujeito pode alienar-se do lado feminino e ser anatomicamente homem ou mulher, o que deveria conduzir a um processo de desidentificaçao e desfalicização. Essa perspectiva tem consequências transcendentais de ordem ideológica e de ordem política [...] e é um dos principais pontos de debate entre a teoria queer e a psicanálise. (SAEZ, 2004, p. 59; trad. nossa)

Várias autoras feministas, dentre elas Irigaray, citam a seguinte passagem como argumento do "machismo" lacaniano: “[...] a mulher nunca será tomada — é isso o que o discurso analítico põe em jogo - a não ser quoad matrem, o que quer dizer que a mulher não entrará em função na relação sexual, a não ser enquanto mãe”. A nosso ver, contra Irigaray, Lacan não está reduzindo a mulher à mãe, mas apontando que se tal redução fosse atingida, a relação sexual poderia se escrever. Mais adiante, Lacan diz que o gozo da mulher se sustentaria na suplência do não todo, nisso que "a faz ausente dela mesma, ausente enquanto sujeito": "ela encontrará aí a rolha desse pequeno $a$ que 
será seu filho" (LACAN, 1972-73/2010, p. 102). O que isso quer dizer? O seu filho tamponaria o buraco que o objeto $a$ escancara e que descentra falicamente a mulher. Se a mulher se reduzisse à mãe, se ela entrasse totalmente como tal nessa função, talvez a relação sexual pudesse existir - pensamos que esse é o ponto que Irigaray perde ao considerar que Lacan endossaria a redução da mulher à mãe ditada pelo patriarcado. Reduzir-se à mãe equivaleria a uma restrição fálica, um suplente ao não todo do seu gozo, ou seu abafamento. Mas a relação sexual não existe; ela só existiria se só girasse ao redor do falo.

Do lado homem, a condição seria a de que, "ali onde ele entra em jogo como significante, ele só entra quoad castrationem [...]” (LACAN, 1972-73/2010, p. 102), já que completamente atrelado ao gozo fálico - esse seria o homem, na medida em que a relação sexual fosse passível de ser escrita num discurso. Homens e mulheres são significantes e, como tais, adquirem sua função. Dito de outra forma, tratar 'homem' como 'castrado' e 'mulher' como 'mãe' é associá-los a atributos, querer defini-los por qualidades, recorrer à empiria - o que é justamente do que Lacan quer se furtar ao recorrer à lógica.

Outro momento sobre esse ponto:

[...] se o desejo, a libido é masculina, pois bem, a querida mulher, é justamente de onde ela é toda, isto é, de onde o homem a vê, e somente dai, que ela pode ter um inconsciente, não é? E para que isso lhe serve? Bem, isso lhe serve, como todos sabem, para fazer falar o ser falante, aqui reduzido ao homem, ou seja - não sei se vocês observaram bem isso, na teoria analítica - para existir apenas como mãe. (LACAN, 1972-73/2010, p. 194)

Lacan reconhece que equalizar e restringir a mulher à mãe é fruto de uma atitude do homem, a ser corroborada pela tradição psicanalítica, mas defende que essa não é a sua. Aquela concepção desconsidera a relação da mulher com o Outro que "faz com que ela nada saiba, porque ele, o Outro, isso é muito claro, sabe menos ainda" (LACAN, 1972-73/2010, pp. 194-5). Saber sobre o gozo da mulher, disso não se sabe — nem homem nem mulher. Nesse sentido, Lacan retira o poder subsumido pelo saber masculino que pretendia ditar o que cabia à mulher, o papel que a definiria, apontando para um não saber a ser verificado por sua experiência de gozo. Esse não saber referente ao gozo da mulher poderia ser uma reatualização do mistério que Freud revelou ter frente ao desejo feminino, e não uma resposta a ele. Daí a questão a respeito do caráter da existência dessa modalidade de gozo. 
Se na tradição filosófica, segundo Fraisse (2010), ao homem cabia o exercício do pensamento, dedicando-se à essência, o corpo dominaria o espírito da mulher, exigindo o cultivo da aparência que a distanciava da verdade. Mas

somente a mulher mística faz exceção nessa história de acesso à verdade. Sem dúvida porque seu acesso à verdade é um acesso direto, sem mediação. Deus fala em Santa Thereza que, por sua vez, transcreve. Nesse caso, a verdade não se encontra nem se revela. A mulher mística deixa transparecer, passar a verdade através dela. Assim a verdade não é contrariada pelo sujeito feminino (FRAISSE, 2010, p. 18; trad. nossa).

Não à toa Lacan cita no seminário XX esta experiência de Santa Thereza como emblemática do gozo feminino. É como se Lacan estivesse restituindo à mulher o encalço à verdade, o que se daria em meio a um processo atípico no qual o corpo, também revalorizado, participa.

Performatizar o gênero feminino ou ser biologicamente mulher são de uma alçada bem diferente da experiência do gozo feminino. Esse gozo outro - que, por sinal, não é acessível a todas as mulheres - ela pode não saber dele, "a não ser que o experimente", e "isso ela sabe [...] quando [...] acontece". Mas, "as psicanalistas mulheres - que tentassem ao menos nos dizer algo, abordar isso. Pois bem, nada! Nem uma palavra! Nunca podemos tirar nada delas". Daí "chamamos isso como podemos: gozo vaginal, o polo posterior do focinho do útero e outras bobagens, é o caso de dizer" (LACAN, 1972-73/2010, p. 152). A mulher como não toda implica um tipo de gozo fora do campo da linguagem independentemente do ponto de vista: a mulher não é um enigma só para o homem.

No Seminário XX, Lacan traz uma interessante colocação a respeito do estatuto do Outro gozo, que a nosso ver condensa o que pode ser dito da relação entre essa experiência gozosa e o gozo fálico: "se houvesse outro, não seria necessário que fosse aquele" (LACAN, 1972-73/2010, p. 133) — "qu'il ne fauxdrait pas", ele diz. Lacan brinca então com a sonoridade de défaut (falha), il faut (é preciso) e faux (falso) no neologismo criado.

A primeira parte da expressão permite a interpretação de que não há outro. Seria necessário supô-lo? Ou há, mas trata-se desse do qual nada nem ninguém tem o que falar. A primeira parte da expressão pode ser falsa, não há outro, mas a segunda pode ser verdadeira. Mas não é porque não há outro que isso implica que ele não seja marcado pela falta, "que a lâmina cortante [deixe] de cair sobre aquele que não é outro" 
(LACAN, 1972-73/2010, p. 134). O gozo que é preciso e que falta: falloir e faillir. Esse gozo falta porque senão se conceberia um ser totalizado - na medida em que somos seres falantes, ele tem que faltar: não há relação sexual... ou pior.

Le Gaufey (2007) também se volta para a obtusa frase de Lacan. Se o gozo fálico é universal, já que de acesso ao sujeito por ser inscrito na linguagem, essa seria a única experiência do gozo? Se há outro, qual é o regime de sua existência? Se houvesse outro, não faria falta que fosse aquele. Primeiro problema: esse "aquele" se refere a quem, ao outro cuja existência supõe a prótase (primeira parte da expressão, marcado pelo condicional) ou àquele de que se parte para designar o outro como outro, ou seja, o fálico?

Le Gaufey (2007, p. 50) propõe: "supondo que existisse outro distinto do fálico, então este já não seria conveniente". Tal gozo dever ser sustentado em sua não existência. Partindo do operador de implicação presente na prótase-apódose, Lacan deduz que de um antecedente falso se pode ir a um consequente verdadeiro - é falso que haja outro, o que não impede que a consequência seja verdadeira, ou seja, não faria (haveria) falta que fosse aquele. O paradoxo é nítido: esse gozo não existe, mas a linguagem confere existência a tudo aquilo que passa pelo dizer — a significação abriga tanto o que existe quanto o que não existe, como no objeto fictício 'círculo quadrado'. "Aquele que não está não deixa de se inscrever no dizer como aquele que não conviria" (LE GAUFEY, 2007, p. 52), e assim cairíamos no trabalho do gozo fálico no que compete a fartar o dizer.

É comum a leitura de que as mulheres se associariam ao gozo feminino e os homens, ao gozo fálico; mas 'se houvesse o gozo feminino, não seria necessário (não faria falta) que fosse esse'. Haveria mais que um gozo, mas não dois. "O Outro gozo designaria assim, à sua maneira, o excesso de referência sobre a significação, da Bedeutung sobre o Sinn fregeanos" (LE GAUFEY, 2007, p. 52). Esse tipo de gozo se inscreve como uma teologia negativa, só pode ser evocado enquanto ausente: é central no ser falante, ao mesmo tempo é nada. Está além do gozo fálico, ao mesmo tempo em que não pode se desvencilhar dele. Não tem lugar próprio, mas sua ausência é crucial para a consistência do gozo fálico em sua universalidade.

A diferença dos sexos não pode ser contada da mesma forma que a diferença de gêneros: se aqui se pode dizer que há dois, o masculino e o feminino, atribuindo consistência a eles, 'homem' e 'mulher' não podem ser contados da mesma maneira — seus termos não podem ser substancializados: “A diferença (sexual), 
inegável, não permite por si só substancializar os termos que opõe, produzir gênero consistentes" (LE GAUFEY, 2007, p. 53). Pela via do gozo, temos um, o fálico, e outro cuja existência é problematizada em Lacan: falta, mas é preciso. Um mais um não é dois: “o 'não existe a relação sexual' com que Lacan formula o dito implícito de Freud significa que, na relação sexual em si, apesar do amor e do desejo, o gozo, enquanto fálico, não dá acesso algum a nenhum gozo Outro" (SOLER, 2005, p. 139).

Apesar disso, o sujeito neuroticamente tenta fazer a relação sexual existir. $\mathrm{Na}$ sua relação imaginária com a mulher, é comum o homem tender a alçá-la ao significante do Outro, a partir de um modelo imaginário que conceberia um Outro do Outro na forma d'A mulher. Inclusive, na leitura astuta de Zizek (1995), esta seria a perspectiva correta na qual as fórmulas da sexuação lacaniana deveriam ser encaradas: a partir da posição da Mulher enquanto exceção, a partir da figura da dama no amor cortês, que compõe a fantasia masculina por excelência. Nesse caso, a dama faria as vezes do pai primordial, que goza sem entraves. Ela seria um dos nomes-do-Pai, uma versão daquele pai sem interditos.

"O homem só apreende a mulher nos desfiladeiros do objeto $a$, ao cabo que supostamente só se encontra no Outro" (RÉCANATI in LACAN, 1972-73/2010, p. 212). Seria na retomada impossível de suas versões do objeto $a$ que o homem alcançaria o Outro e a mulher se verteria ao significante do Outro barrado. Segundo Zizek (1995), o $S(A)$ aponta para a impossibilidade do significante do Outro — não há Outro do Outro. Considerando-se a inconsistência do Outro, o falo entra em cena dando forma a essa impossibilidade, o que pode ocorrer nas figuras que fogem à castração e gozam sem limites, como o pai da horda e a dama no amor cortês, na fantasia que o homem cria: "o homem crê criar ele crê, crê, crê, bom! Ele cria, cria, cria a mulher! Sim!" (LACAN, 1972-73/2010, p. 257).

Apesar das controvérsias a respeito das fórmulas da sexuação, "a única constante entre os comentadores é a de que a introdução do gozo feminino, como não todo, significa o reconhecimento radical de experiências de indeterminação ou de não identidade no núcleo mesmo da sexualidade" (DUNKER, 2011, p. 513). E é a essa perspectiva desidentificatória que Drucilla Cornell (1995) vai recorrer como forma de convencer suas colegas feministas da utilidade de Lacan para seus propósitos. Interessa a ela investigar a maneira com que construções simbólicas como Mulher se atam a fantasias que, inconscientemente, comporiam o que se considera como feminilidade dentro dos moldes da norma heterossexual. Lacan importa pela potente teoria do 
inconsciente tratado a partir de instrumentos da linguagem, pela consideração de que esse é um campo inconsistente, e pelas consequências políticas que podem ser depuradas do seu aforismo "A mulher não existe". Essencializar a mulher leva ao seu congelamento em figuras secundárias ditadas pela ordem masculina, na ótica da feminista. "O apelo a uma identidade estabelecida e compartilhável pode obscurecer a significância desse processo inconsciente de cisão e transitoriedade" (CORNELL in BENHABIB, 1995, p. 77). Na leitura de Cornell, Lacan não dava ênfase às construções sociossimbólicas que sustentariam a ideia de feminilidade, nem se vertia a aspectos biológicos para o entendimento da diferença sexual, mas apresentava uma teoria sobre a lacuna que há entre esses dois polos, "e é nessa brecha que o feminismo deve operar" (CORNELL in BENHABIB ,1995, p. 86).

Ainda nas palavras da autora, "a realidade só se sustenta nas estruturas da fantasia, é o que Lacan quer dizer quando escreve que não há significado fixo para as mulheres dentro da ordem simbólica" (CORNELL in BENHABIB, 1995, p. 86). O estatuto lacaniano da não existência da mulher, segundo Cornell, implica o fracasso da tentativa de fixar absolutamente o que significaria Mulher, permitindo possibilidades transformadoras inesgotáveis - como não existe significado definitivo a estabelecê-la, “ela pode 'ser' qualquer coisa" (CORNELL in BENHABIB, 1995, p. 87). Nesse sentido, o aforismo lacaniano viria ao auxílio do feminismo que pretende derrocar as teorias que se prestam a decretar a verdade da diferença sexual - e que levam ao aprisionamento das mulheres, conclui Cornell.

Agora em outro contexto, Brousse (1991) pensa o aforismo lacaniano em certas manifestações clínicas que visariam contrariamente a estabelecer A mulher. Se el'A não existe, isso não quer dizer que não se tente alcançá-la. Brousse (1991) considera que a clínica forneceria exemplos da mirada de dar consistência ao Outro sexo e fazer a relação sexual existir: no campo da fantasia, teríamos a mascarada e a maternagem; no campo do amor, a erotomania e a homossexualidade.

Mascarada e maternagem seriam processos dados a partir dos recursos em jogo no lado 'homem' das fórmulas da sexuação. A mascarada seria uma manifestação fálica que tenderia a suturar da falta do Outro ao proclamar "Mulher como o Outro absoluto: o Outro do Outro" (BROUSSE, 1991, p. 123). A aproximação d'A mulher se daria aos moldes da fantasia masculina e poderia levar ao fetichismo. A maternagem seria outra resposta fálica — frente à falta de significante do Outro, A mulher seria atingível ao sujeito enquanto mãe de um filho investido falicamente em fantasia. 
$\mathrm{Na}$ erotomania psicótica, $\mathrm{A}$ mulher encontra $\mathrm{O}$ homem. $\mathrm{O}$ amor garantiria a essa mulher ser alçada ao status universal, ao mesmo tempo em que ela lhe proporcionaria acessar o gozo sem limites que teve de renunciar para fazer parte do conjunto dos homens. Em certa vertente da homossexualidade, o amor ao Outro sexo se daria aos moldes do ideal do amor cortês, tal como Freud descreve no caso da jovem homossexual — aqui faz eco à tese de Zizek (1995), de a dama no amor cortês ser um dos nomes-do-Pai. De toda forma, Brousse (1991, p. 122) salienta que tais quadros clínicos seriam formas inevitavelmente vãs, marcadas por uma série de desvios, que se pretendem dar consistência ao Outro sexo e fazer A mulher existir.

Apresentadas algumas leituras deste polêmico e potente aforismo, passemos à escrita lógica da sexuação.

\subsection{As fórmulas da sexuação}

A teoria que fundamenta as fórmulas da sexuação começa a ser elaborada no Seminário XVIII. No XX, Lacan apresenta sua tábua:

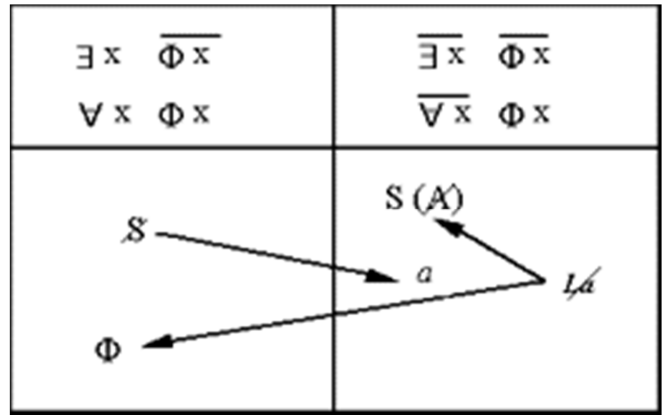

A parte de cima pode ser lida da seguinte maneira:

Lado esquerdo como posição homem: existe x que nega a função fálica; todo $x$ se submete à função fálica.

Lado direito como posição mulher: Não existe x que negue a função fálica; não todo x se submete à função fálica.

Como já salientamos, elas devem ser lidas a partir da combinação de elementos da lógica proposional de Aristóteles ao lado do quantificador universal, $\forall, \mathrm{e}$ do existencial, $\exists$ : particular negativa, universal afirmativa, particular afirmativa e 
universal negativa. Num momento posterior, discorreremos sobre a adição das modalidades lógicas 'necessário', 'possível', 'impossível' e 'contingente'.

Como forma de melhor entendermos a lógica que rege tais fórmulas, tratemos duas proposições, exemplificando-as a partir de "árvore" e "alta". Proposição afirmativa: a árvore é alta; proposição negativa: a árvore não é alta. Do ponto de vista da quantidade, as proposições podem ser de três tipos: universais, particulares e singulares — Lacan recorre às duas primeiras. Proposição universal: toda árvore é alta (universal afirmativa); proposição particular: alguma árvore é alta (particular afirmativa). Suas vertentes negativas seriam: nenhuma árvore é alta (universal negativa); alguma árvore não é alta (particular negativa).

A partir de então, Lacan, no Seminário XVIII, retoma em parte o que pôde extrair de Peirce e a função fálica será cifrada pela letra $\Phi$.

Podemos afirmar que, do lado 'homem', opera o seguinte funcionamento lógico: "existe $\mathrm{x}$ (algum $\mathrm{x}$ ) que não phi de x" é uma proposição particular negativa e "todo x se submete a phi de x" é uma proposição universal afirmativa. Disso, então, deduziríamos que a particular afirmativa e a universal negativa poderiam ser aplicadas ao lado mulher? Não. Lacan aqui opera subversões na lógica aristotélica. "Não existe x que não se submeta a phi de x" não equivale à proposição particular afirmativa "algum $\mathrm{x}$ se submete a phi de $\mathrm{x}$ " — a dupla negação não equivale a uma afirmação. Outra subversão diz respeito à universal negativa: "não todo x se submete a phi de x" não é o mesmo que "nenhum x se submete a phi de x". "Não é por eu ter-me servido de uma formulação feita da irrupção da matemática na lógica que me sirvo dela exatamente da mesma maneira. [...] a maneira pela qual a utilizo é tal que de modo algum é traduzível em termos de lógica das proposições" (LACAN, 1971-72/2012, p. 99).

Crucial discorrermos sobre o regime de existência em Lacan. Há uma coletânea de enunciados negativos sobre a existência: O Outro não existe; não existe metalinguagem; A mulher não existe; A relação sexual não existe. Fica evidente que, para Lacan, a existência - além de atrelada ao particular - comporta a experiência do negativo: tal como lemos nas fórmulas da sexuação, 'existe um que não' e 'não existe um que não' - ou seja, a existência não é composta de um conjunto de experiências positivas nem se liga ao universal. Tal existência não prevê uma essência, daí não se tratar do homem e da mulher enquanto substância. "Esse existe não é, por exemplo, nada além de um número para satisfazer uma equação" (LACAN, 1971-72/2012, p. 21), sendo que "o número não tem nada a ver com a linguagem, e é mais real do que 
qualquer coisa [...]" (LACAN, 1971-72/2012, p. 198) - Lacan recorre ao conceito de número em Frege e ao Um de Parmênides, contrários ao Um que a metafísica de Aristóteles associa ao ser.

O universal, no lado homem, só é constituído na medida em que um particular o negue, tal como se lê em "O aturdito" (LACAN, 1973): o particular em Lacan não é generalizável, e é dele que se parte para se fundar o universal. Isso é fundamental para a teoria da sexuação porque aqui Lacan também procede por outra subversão ao ir contra o princípio da não contradição. Afinal de contas, se toda árvore é alta, como pode existir uma árvore que não o seria? Esse particular que se furta ao universal é o ao-menos-um lacaniano ${ }^{34}$.

O universal aqui não suscita nenhuma necessidade — a necessidade está do lado da existência. $\mathrm{V}$ deve ser lido como letra que indica pertencimento a um conjunto determinado. Segundo Le Gaufey (2007, p. 89), Lacan recorre ao modelo de Russell — que contempla o paradoxo "conjunto que não pertence a si mesmo" — para dar o passo seguinte: pensar em elementos que escapem à coletivização (o 'ao menos um', elemento necessário para a constituição do universal).

Do lado mulher, Lacan apresenta a novidade da negação do quantificador universal. A negação determina que tais elementos não são passíveis de serem escritos; o não todo da mulher pressupõe algo que não pode ser escrito: "podemos dizer que elas não são a escrever, porque não é de todo $x$ que se pode postular a função $\Phi$ de x. É por esse não é de todo $x$ que se postula a mulher" (LACAN, 1971/2009, p. 137). Importante frisar que esse não todo não é um partitivo, pois todos os elementos estão sujeitos ao mesmo regime fálico - não se trata, então, de que alguns elementos são submetidos à função fálica e outros, não. O passo lógico não evidente é que, mesmo com todos os elementos se submetendo à função fálica, não se chega jamais a um todo.

Há uma disparidade entre o universal e o não universal próprio ao feminino. O 'não todo' não é o universal negativo. O 'não todo' não é sinônimo de 'nenhum'. A partir da negação do "todas as mulheres", fica impossibilitada a escrita da relação entre uma entidade que possui um conjunto de certos valores (homens) e outro que não os possui (mulheres). Não há o conjunto das mulheres tal como se funda o conjunto dos

\footnotetext{
${ }^{34}$ Cabe destacar que a exceção não deve ser confundida com singular (proposição singular iniciado por "este"), um indivíduo, tal como representaria a figura do pai totêmico - com o termo 'ao menos um', há a possibilidade de vários elementos sustentarem a exceção. Em "O aturdito", Lacan (1973) situa o "ao menos um' no lugar do zero na função hiperbólica 1/x. Zero aponta para o limite - a função tende ao infinito, à medida que $x$ tende ao zero, mas nenhum valor $\mathrm{o}$ atinge.
} 
homens a partir do paradoxo de Russell. É justamente essa função que torna impossível o acesso à relação sexual.

Lacan pontua algo que nos parece fundamental: a proposição na qual o não todo opera é a de uma dupla negação, dupla negação essa que não implica uma afirmação de existência: "não basta negar o não todo para que, de cada um dos dois pedaços, se me posso exprimir dessa maneira, seja afirmada a existência" (LACAN, 1971-72/2012, p. 21). A existência nesse contexto é de um regime diferente da que está em jogo no outro lado das fórmulas. Comparando com o regime de existência da proposição que apresenta o 'ao menos um’ e à lógica aristotélica, Lacan afirma: “Ao propor os dois termos da direita no meu grupo de quatro termos [...], ouso enunciar algo que patentemente falta à referida lógica. Se posso fazê-lo, é na medida em que o termo existência mudou de sentido nesse intervalo. Não se trata da mesma existência [...]" (LACAN, 1971-72/2012, p. 135). Temos, então, dois tipos de existência, e outra lógica rege a existência do lado mulher: "a lógica porta a marca do impasse sexual" (LACAN, 1971/2009, p. 133).

Le Gaufey (2007) adverte que a particular, no contexto utilizado por Lacan, deve ser lida como a particular mínima aristotélica, ou seja, que desse ‘algum’ (alguns), indeterminado, nunca se chega a 'todos' - particular e universal nunca se confundem, a não ser na particular máxima. Se a particular está ligada à existência, assim se barra a possibilidade de uma particular, como máxima, acessar a existência: o todo fica desprovido de existência e o não todo passa a ser encarado como uma "existência sem essência" (LE GAUFEY, 2007, p. 103). Tal expressão não quer dizer que Lacan está negando a existência de cada mulher, assim como Russell não nega a existência de conjuntos que não pertencem a si mesmos — o que acontece é que "nenhum conjunto os coletiviza" (LE GAUFEY, 2007, p. 115).

Do lado 'homem', com a negação da existência (particular), chega-se a 'todo' (universal). Já do lado 'mulher', da negação da existência, não se pode concluir o 'todo'. Se, na leitura de Gaufey (2007), ao lado do não todo x, existisse um x que negasse a função fálica, a conjunção entre os que possuem determinada propriedade e os que não a possuem poderia levar ao 'todo' - o que Lacan quer evitar, daí negar o quantificador existencial na dupla negação 'não existe x que não $\Phi$ de x': "aqui reina o não todo, no sentido de que não há nenhum x para não satisfazer a função $\Phi$; e que, no entanto, os que a satisfazem não constituem o conjunto de todos os elementos que a satisfazem" (LE GAUFEY, 2007, p. 103). Os elementos possuem um traço comum, mas 
não se agrupam num conjunto no qual cada um seria um elemento. Então não há exceção, não existe x que não $\Phi$ de x, e aqueles que satisfazem a função não compõem um universal. A negação do universal produzir a existência, negada, é um processo logicamente complexo.

Já no Seminário XVIII, Lacan (1971/2009, p. 133) afirmava que todo homem é um significante: "todohomem, [touthomme]". Mas, para que isso se inscreva, algo tem que ser posto de fora, foracluído. Ou seja, o universal se funda a partir de uma operação que se passa no nível existencial, todohomem só pode ser pensado junto à existência de um que diz 'não', ao menos um. Quanto à mulher, a operação é outra, "[...] discordancial. Não é por haver um para todo $x, \forall \mathrm{x}$, que posso escrever ou não escrever $\Phi x$. Não é por existir um $x$, $\exists$ x, que posso escrever ou não escrever $\Phi x "$ (LACAN, 1971/2009, p. 132).

Le Gaufey (2007, pp. 92-3) afirma que, em Damourette e Pichon, discordância "é uma maneira não tanto de negar, que seria o trabalho do foraclusivo, mas de marcar uma diferença, uma distância, como se detecta na introdução da palavra francesa " $n e$ "'. Enquanto esta serve para reforçar um subjuntivo, o foraclusivo se aproximaria de complementos indispensáveis da negação, como 'pas', 'rien' ou 'jamais'. Daí o fato de que o não todo, do lado da discordância, "não expressa que não haja nada, senão que aquilo que há não se conforma a nenhum todo" (LE GAUFEY, 2007, p. 93). Já a negação foraclusiva entra em jogo no 'existe um que não'. A confrontação entre discordância e foraclusão é importante por revelar o caráter do intercâmbio entre universal afirmativa e universal negativa, que não se dá pela simples oposição como verdadeiro/falso ou pela pura contrariedade entre os elementos.

Outro ponto: se do lado esquerdo é preciso essa exceção, 'ao menos um', para que todos os outros possam funcionar, do direito o 'não todo x não $\Phi x$ ' é "fundado" sem aquela exceção constitutiva - nesse sentido, nada na mulher nega a função fálica. Se o modo de negação do lado 'homem' é a foraclusão e a do lado 'mulher' é a discordância, "nosso não todo é a discordância" (LACAN, 1971-72/2009, p. 22). Ou seja, "não podemos nos servir da negação de um modo tão simplesmente unívoco quanto fazemos na lógica das proposições, na qual tudo que não é verdadeiro é falso" (LACAN, 1971-72/2012, p. 36). Lacan anuncia o indecidível no contexto do valor de verdade: não se pode dizer se se trata de verdadeiro ou falso, não há como decidir. Se do lado homem - entre os níveis existencial e universal — temos uma 
contradição (o ‘existe um' que contradiz o universal); do lado 'mulher', entre esses dois níveis se imiscui o indecidível.

Dessa forma, podemos dizer que as fórmulas da sexuação contemplam a negatividade não deduzida da simples oposição, inversão ou anulação de um dos elementos em jogo. Estamos no embate entre a negação predicativa ('não é submetido à função fálica') e a negação ontológica ('não existe' e 'não todo'), que acabam determinando os diferentes modos de gozo, tal como se veicula no lado 'homem' e no lado 'mulher'.

Le Gaufey apresenta uma interpretação no mínimo inusitada para a universal negativa: sua escrita seria 'não existe x que não $\Phi$ de x'. Lacan teria escrito a universal negativa com a negação do quantificador existencial. Contudo, o 'não alguns' deveria ser lido com sinônimo de 'nenhum' — "aqui radica indiscutivelmente o ponto culminante de sua invenção, muito mais que pelo lado do não todo" (LE GAUFEY, 2007, p. 112). Lacan quer definitivamente romper com a simetria a partir da universal negativa que afirma que "ninguém diz 'não" sendo que, justamente, "não todos dizem sim'. Todo esse malabarismo para fugir da armadilha que permitiria opor o 'todo homem' com um suposto 'todo' da mulher. Mas, na leitura de Ayouch:

Sem entrarmos em detalhes, observemos também que, no Seminário
XX (Lacan, 1998), as fórmulas da sexuação definem uma postura
feminina e masculina na relação com o falo e o gozo, mas, se elas
abandonam a referência a um sexo definido "naturalmente", elas
invocam os grupos universais dos "homens" e das "mulheres",
distinguidos de forma binária pela convocação do pai da horda
primitiva. Porém, tanto estes grupos "universais" quanto o pai da
horda primitiva são constituídos e reconhecidos de forma
irredutivelmente historicizada, inscrita no postulado de um dualismo
de gênero apresentado como inquestionável e ahistórico - lá onde se
poderia pensar, além do dualismo, numa diversidade múltipla.
(AYOUCH, 2014, p. 62)

A nosso ver, as fórmulas da sexuação não pretendem reestabelecer uma dualidade que funcione por pares de opostos — pelo contrário, é disso que Lacan quer fugir quando recorre aos termos 'gozo fálico' e 'Outro gozo'. O que se escreve no lugar da universal negativa aponta justamente para um não capturável pelas redes da função fálica. Não temos dois universais a serem pareados. Pensamos que recorrer à lógica permite a Lacan se esquivar das marcas históricas que o binarismo de gênero comporta, 
além de lhe fornecer um meio de conceber a diferença para além daquela intrínseca ao dualismo dos gêneros.

Relembremos nosso terreno.

Se, segundo Lacan (1971-72/2012, p. 39), o objeto da lógica era tratar da rede articulável do discurso, verificou-se que tal campo não poderia ser totalmente abarcado pelo conhecimento. Nas articulações lógicas, premissas, axiomas nos quais a aritmética se baseia como forma de demonstração ou refutação, algo resta inapreensível: "nesse ponto [...] pomos o dedo no que se opõe à captura completa do discurso no esgotamento lógico, o que introduz nela uma hiância irredutível. É aí que designamos o real" (LACAN, 1971-72/2012, p. 39). O real se afirma nos impasses intrínsecos à lógica. Essa hiância lógica aponta para o passo dado por Gödel ao mostrar a incompletude dos sistemas. Sempre existe algo que não pode ser abarcado pelo modo de demonstração aceito: "o real pode se definir como o impossível, é como ele se revela no assentamento do discurso lógico. [...] ele é o paradigma do que questiona o que pode sair da linguagem" (LACAN, 1971-72/2012, p. 40). E é munido dessa incursão lógica da linguagem que Lacan vai em direção do que a exploração do inconsciente revela, ou seja, que não há simbolismo sexual universal, tal como Jung pregava, mas castração "rigorosamente fundamental naquilo que não instaura, mas impossibilita o enunciado da bipolaridade sexual como tal" (LACAN, 1971-72/2012, p. 41). Os dois polos, homem e mulher, não podem ser enunciados, nem uma suposta relação entre eles. Todo esse exercício dentro da lógica é requerido para formalizar a não relação sexual, a partir do que Lacan propõe diversas subversões: contesta-se o princípio de não contradição (lado 'homem'); duas negações não implicam uma afirmação, nega-se o quantificador universal sem que esse procedimento se confunda com o universal negativo (lado 'mulher'). Lacan recorre a dois tipos de negação (foraclusão e discordância), dois regimes diferentes de existência, e a só um universal.

Avançando em sua incursão na lógica, Lacan acrescenta os operadores da lógica modal. Nesse sentido, só há universal, 'todos', no nível do possível. O necessário recai sobre o um-a-menos - é necessário este que negue a função fálica para que o todo se constitua. Do lado 'mulher', negação do quantificador universal, 'não todo', relacionado agora ao impossível.

A mulher se situa a partir de que não todas podem ser ditas com verdade em função do argumento no que se enuncia da função fálica. $\mathrm{O}$ que é esse não todas? É isso que merece ser interrogado como 
estrutura. Com efeito, ao contrário da função da particular negativa, ou seja, que há algumas que não o são, é impossível extrair tal afirmação do não todas. Fica reservado ao não todas indicar que a mulher tem, em algum lugar ${ }^{35}$, relação com a função fálica, e nada mais. (LACAN, 1971-72/2012, p. 44)

Em outra perspectiva, é impossível que a mulher não tenha relação com a função fálica (não existe nada que a negue). Se do lado 'homem' o 'ao menos um' serve de exceção (que acaba por funcionar como um ponto ideal a partir do qual os homens tendem a mirar, via identificação), do lado direito temos um sem exceção (inexistência de x). O 'não existe x não $\Phi x$ ' implica ausência de limite: “o fato de não haver exceção também não garante o universal da mulher" (LACAN, 1971-72/2012, p. 107) — o sem exceção impede qualquer consistência ao não todo.

Mas falar que a mulher é não toda não quer dizer que ela não se submeta à função fálica, pelo contrário. Nos termos de Zizek (1995), no lado 'homem', enquanto a cisão é externalizada, aqueles que caem sob a função fálica são separados daquele que não cai (exceção); no caso da mulher, a cisão é internalizada: cada mulher é dividida em si, parte dela se submete à função fálica e parte, não. Esse seria um dos paradoxos da sexuação na visão do filósofo: do lado 'mulher' não existe x que não se submeta, não há como resistir à função fálica (não há exceção), ao passo que algo nela não se submete (esse algo faz exceção). "Há um curto-circuito e falo coincide com sua própria autolimitação, com o estabelecimento de uma exceção não fálica” (ZIZEK, 1995).

Para existir a relação sexual, dois universais seriam requeridos; contudo, não existe toda mulher. "A mulher só pode ocupar seu lugar na relação sexual, só pode sê-lo, na qualidade de uma mulher" (LACAN, 1971/2009, p. 133). Nesse sentido, a mulher só existe como toda aos olhos do 'ao menos um'.

Nesse mesmo Seminário XVIII, Lacan (1971/2009, p. 65) já decretava que "uma mulher só tem um testemunho de sua inserção na lei, daquilo que supre a relação, através do desejo do homem”. Se considerarmos aqui 'lei' como da alçada do universal, seria através do homem que o particular da mulher seria elevado ao universal, A mulher. O homem faz A mulher - o desejo do homem seria orientado para el' A, não para essa ou aquela. Se o universal do homem tem como condição o "um que não", o suposto universal da mulher requereria o desejo do homem como mediação. Mas A mulher não existe e não há relação sexual, a não ser em fantasia.

\footnotetext{
${ }^{35}$ A Versão da Staferla do Seminário XIX adota, na página 43, ao invés deste "em algum lugar", "alguma parte, e não mais".
} 
Apesar de também já ter sido anunciada nos seminários anteriores, é no Seminário XX, que Lacan estabelece com maior rigor o tema dos parceiros do homem e da mulher, parte inferior da tábua da sexuação. O homem só se liga ao objeto $a$, compondo sua cena fantasmática:

O objeto, que se coloca no lugar daquilo que, do Outro, não poderia ser percebido. É na medida em que objeto $a$ desempenha em algum lugar e de um ponto de partida, de um só, o do homem, o papel do que vem no lugar do parceiro faltante, que se constitui aquilo que costumamos ver surgir no lugar do Real, ou seja, o fantasma. (LACAN, 1972-73/2010, p. 138)

Do lado esquerdo, a mulher é tomada como objeto na fantasia do homem, do direito - ela busca o falo ao lado do homem. Mas, ao mesmo tempo, a mulher acessa o significante da falta do Outro e, nesse processo, alcança um gozo suplementar. Importante frisar que se trata de um gozo suplementar, e não complementar ao falo estamos num terreno de gozo além do prescrito pelo falo, onde justamente Lacan havia indicado que deveríamos buscar a diferença entre homem e mulher.

Lacan faz a ressalva de que a disposição do sujeito (\$) do lado esquerdo não se deu como forma de dar prevalência ao homem: "desse homem que, certamente não para privilegiá-lo, de modo algum, eu inscrevi aqui com $\$$ e com esse $\Phi$ que o sustenta como significante [...], esse $\$$ nunca tem de lidar, enquanto parceiro, senão com essa $a$ inscrito, como tal, do outro lado da barra" (LACAN, 1972-73/2010, p. 169).

Do lado da mulher, as coisas se passam de outra maneira, "diferença radical do que se produz do outro lado" (LACAN, 1972-73/2010, p. 138): a A mulher não acessa o objeto $a$ - é o homem que vai buscá-lo do lado dela. Esse A mulher se relaciona com esse $S(A)$ : esse Outro, onde se inscreveriam todos os significantes, na verdade não é esse, é Outro. A Mulher tem relação com o "significante desse Outro, na medida em que, como Outro, ele só pode permanecer sempre Outro" (LACAN, 197273/2010, p. 170), radicalmente Outro. Não há Outro do Outro, mas é possível conceber um significante justamente desse Outro barrado: significante da falta de significante, simbólico com real, cujo acesso pode proporcionar um gozo suplementar — mas não só ou não toda, já que também aciona o $\Phi$. Gozo Outro e gozo fálico são incompatíveis, decretam experiências inconciliáveis que impossibilitam a complementariedade homem-mulher. 


\subsection{Políticas da sexuação}

Se as fórmulas da sexuação revelam que a função fálica vale para ambos os parceiros, somos levados a pensar sobre o que os diferenciaria:

Revela o fato de que a função fálica domina igualmente os dois parceiros, isto, no entanto, não os torna diferentes, persiste o fato de que é primeiro em outro lugar que devemos procurar a diferença. E é nisso que as fórmulas escritas no quadro merecem ser interrogadas nas duas vertentes, opondo-se a vertente esquerda à vertente da direita, opondo-se o nível superior ao nível inferior. (LACAN, 1971-72/2010, pp. 98-9)

Dessa comparação se detecta que lado 'homem' e lado 'mulher' não se voltam à função fálica da mesma forma, o que traz consequências no plano do gozo. "Entre o que funda simbolicamente a função argumental dos termos $o$ homem e $a$ mulher, persiste a hiância da indeterminação de sua relação comum ao gozo. Não é a partir da mesma ordem que eles se definem em relação a ela" (LACAN, 1971-72/2012, p. 44).

Lado 'homem', lado 'mulher' não se acessam: "Em ambos os casos, nesses dois níveis, que como tais são independentes, e não se trata, em absoluto, de fazer de um a negação do outro, mas ao contrário, de fazer de um obstáculo ao outro" (LACAN, 1971-72/2012, p. 99).

A nosso ver, o que interessa a Lacan, ao discorrer sobre a sexuação, é principalmente tratar do que leva um a não ter acesso ao outro. "O gozo fálico é obstáculo pelo qual o homem não consegue, eu diria, gozar do corpo da mulher, precisamente porque aquilo de que ele goza é desse gozo, o do órgão" (LACAN, 197273/2010, p. 19). O homem não alcança a mulher porque a experiência de gozo que lhe cabe o impede.

Os elementos subsistem, como negados (existe - não existe; todo - não todo), distribuindo os sujeitos, repartindo-os em homem e mulher, de modo a não se relacionarem. Não tem como, as posições são só estas: "quem quer que seja dos seres falantes se inscreve à esquerda, ou então à direita" (LACAN, 1972-73/2010, p. 168).

É nesse momento que Dunker (2011, p. 513) considera surgir a articulação política da sexuação. Entre os comentadores de Lacan, há uma diversidade de entendimentos sobre o escopo ao qual se deve aplicar a noção de homem e de mulher, contempladas pelas fórmulas da sexuação. A duplicidade do gozo seria uma atualização 
da bissexualidade freudiana? As posições masculina e feminina seriam, como os discursos, permutáveis: ora em uma, ora em outra? Ou cada sujeito teria uma vertente masculina e outra feminina? Outros fatores podem ser pensandos nessa teoria, tais como escolha de objeto sexual, desejo, ou mesmo identificação? Qual o estatuto político dos aforismos "não há relação sexual" e "A mulher não existe”? Reforçam a submissão feminina na sociedade? A divisão em lado 'homem' e lado 'mulher' ratifica a binaridade tão combatida pelos estudos de gênero? Nesse sentido, pretendemos agora apresentar diferentes leituras e interpretações da sexuação. A forma como é encarada define seu alcance político.

\subsubsection{Para além da anatomia, da prática sexual e do binarismo.}

Lacan relata que as posições 'homem' e 'mulher' não são exclusividade de homens e mulheres, anatomicamente falando. Quando ele vai tratar da mulher, ao negar o quantificador universal, afirma: "a negação incidindo sobre o não todo e não sobre a função... quando digo isso: que se coloque, se posso me exprimir assim, que se coloque sob a insígnia das mulheres um ser falante qualquer" (LACAN, 1972-73/2010, p. 150).

Então 'homens biológicos’ podem se colocar do lado mulher. “[...] como São João da Cruz... sim, porque não se é obrigado, quando se é macho, a se colocar do lado $\forall x$.Фx, pode-se também se colocar do lado do 'não todo'. Há homens que estão nesse lugar tanto quanto as mulheres [...]" (LACAN, 1972-73/2010, p. 154). O aparato biológico não só não determina os gêneros, como, na sexuação lacaniana, não prescreve a modalidade de gozo do sujeito.

Essa passagem de Lacan dá indícios de que o posicionamento do lado 'homem' das fórmulas não exige coerência com a expressão do gênero masculino: “A qualquer ser falante é permitido, quem quer que ele seja, provido ou não dos atributos da masculinidade - atributos que restam a determinar —, provido ou não desses atributos, inscrever-se do outro lado" (LACAN, 1972-73/2010, p. 169).

Quanto à prática sexual, a função fálica não exige exclusividade:

Quantificador $\forall x$, isto é, todo $x$ é função, função matemática de $\Phi$ de $\mathrm{x}$... Isso quer dizer que do lado em que (o homem) se coloca, em suma, por escolha... as mulheres são livres de aí se colocarem também, se isso lhes der prazer, hem? Todos sabem que há mulheres fálicas! É claro que a função fálica não impede os homens de serem 
homossexuais, mas é também ela que lhes serve para se situar como homens e abordar a mulher. (LACAN, 1972-73/2010, p. 149)

Se sexo biológico, gênero - sob o termo "atributos" e escolha de objeto sexual - não são fatores que andam lado a lado, o gozo entra aqui como um quarto elemento a também não exigir coerência nessa cadeia. As diferentes experiências de gozo não determinam nem são determinadas por aqueles elementos.

Se a mulher é não toda fálica, Lacan nos lembra que: "ela tem diversos modos de abordar esse falo, e de ficar com ele, hem! $\mathrm{E}$ isso importa, porque não é por estar 'não toda' na função fálica, que ela não está ali de modo algum. Ela está ali, não de modo algum, só que existe algo a mais" (LACAN, 1972-73/2010, p. 151). Lacan considerou que tal desdobramento teórico interessaria ao feminismo:

Há um gozo - já que nos limitamos ao gozo, gozo do corpo — que é... se posso me exprimir assim, porque afinal, por que não fazer disso um título de livro?... seria para o próximo da coleção Galilée: "Para além do falo" [Au-delà du phallus], seria bonito, hem! E depois, isso daria outra consistência ao M.L.F [Mouvement de Libération des Femmes, 'Movimento de Liberação das Mulheres']!. Um gozo para além do falo, hem? (LACAN, 1972-73/2010, p. 151)

Mas a feminista Márcia Arán aponta para a limitação dessa proposta de ir "além do falo":

[...] torna-se fundamental contextualizar historicamente esse debate e afirmar que a teoria da diferença sexual na psicanálise, tanto em Freud quanto em Lacan, é a forma masculina de se inscrever na história conflitiva que marcou a diferença entre os sexos na cultura ocidental. Além disso, deve-se considerar a existência do lado feminino, sem defini-lo apenas como negativo. A positivação do feminino exigiria pressupor não apenas um além do falo, mas, antes de tudo, uma outra forma de erotismo que não tenha no falo a sua referência. (ARÁN, 2009, p. 662)

O que nos faz pensar se não seria justamente este 'além do falo', que Áran reconhece como próprio ao feminino, o que permitira à mulher uma outra forma de erotismo, já que vinculada ao outro gozo - mas, de acordo com Lacan, não há como prescindir do falo. Outro ponto de discórdia diz respeito à "positivação do feminino", justamente o que Lacan implode com seu aforismo "Não há relação sexual". Um tipo de gozo, ou um tipo de erotismo, a nosso ver, não deve ser atrelado à positivação nem do masculino nem do feminino. Pensamos que essa positivação desejada só se sustentaria 
no semblante ou na performance, que há muito sabemos só ter contorno enquanto atuados. Áran também considera que a teoria da diferença sexual em psicanálise teria se dado aos moldes masculinos. David-Ménard apresenta interpretação correspondente.

Para David-Ménard (1998), a disjunção estabelecida entre lado 'homem' e lado 'mulher' a partir da função fálica só seria estabelecida a partir da visão do homem sobre a mulher, não a que ela possa ter sobre si própria. Nesse caso, as fórmulas da sexuação seriam uma construção masculina.

A mulher não está fora da linguagem, mas como inscrever sua relação ou sua afinidade com aquele ponto de falha do Simbólico nas fórmulas da sexuação? Segundo David-Ménard, tais fórmulas

\begin{abstract}
parecem talhadas sob medida para formalizar certos aspectos da sexualidade masculina [...] Lacan ousou, depois de Freud, ir mais longe. Mas em matéria de descrição do ponto impossível que polariza o encontro dos sexos, ele sem dúvida fracassou em fazer do feminino outra coisa que o limite interno do masculino. (DAVID-MÉNARD, 1998, p. 113)
\end{abstract}

A partir de tais considerações, David-Ménard desenvolve sua teoria a respeito do que retrataria uma mulher (não A mulher, ela destaca): "é que no gozo ela não pode não saber que o pênis não é o falo. Uma mulher não pode partilhar da certeza da sua unidade [...]" (DAVID-MÉNARD, 1998, p. 114). Tem de saber que o pênis de um homem que a faz gozar não é o falo; além do mais, há de se reconhecer que o falo não é o emblema de todo acesso à simbolização do desejo. “[...] ao confundir, como faz talvez necessariamente um homem, pênis e falo, Lacan inscreve uma dependência das mulheres com relação ao Simbólico, que consistirá neste fato de que elas seriam, enquanto mulheres, indefiníveis no simbólico" (DAVID-MÉNARD, 1998, p. 116).

David-Ménard segue enfatizando que, no gozo, uma mulher não pode não saber que o pênis não é o falo. O pênis só a faz gozar na medida em que representa aspectos decisivos do que possibilita a essa mulher ser desejada. Há de se separar o erótico e o simbólico, sempre sob esse risco de que o simbólico seja erotizado naquela equação perigosa para as mulheres. Elas têm de saber o que esperar do homem; e, se se mantiverem fiéis àquela equivalência, necessariamente se decepcionarão, obrigando-as a simbolizar por conta própria — ou lançando mão de outros recursos — a parcela da vida sexual que não recai sob o falo.

Por fim, David-Ménard conclui sua posição de contestação: 
Com efeito, ao descrever os trajetos próprios das experiências de perda, de perdição e de substituição de objetos do lado da mulher, não se faz da sexualidade feminina uma entidade independente de sua relação com o masculino. Lacan tem razão em dizer que o feminino não é uma natureza, mas ele não é por isso um mais-além do masculino, nem um posição sexuada menos marcada pelo objeto $a$ e diretamente em relação com o que falta ao Outro. (DAVIDMÉNARD, 1998, p. 116)

A formalização do todo, do não todo e o enunciado 'A mulher não existe' podem ser lidos como uma versão mais astuta do tomar o homem como referência e subjugar a mulher. Arán, assim como David-Ménard, defende tal interpretação:

[...] para Freud, o destino da sexualidade feminina é a inveja do pênis, tendo na sua versão positiva a maternidade e, na negativa, a renúncia e a virilização. Já para Lacan, considerando-se as suas fórmulas de sexuação, o lado feminino acaba sendo um limite interno ao masculino, onde a mulher aparece como "não toda" inscrita na função fálica. A própria escolha do falo como significante do desejo significa uma posição sexuada de quem só pode conceber o feminino a partir da exclusão. $\mathrm{O}$ que se observa nesse contexto é uma espécie de versão psicanalítica para o modelo da dominação masculina em que, como diz Lacan, "a mulher não existe”. (ARÁN, 2009, p. 659)

É como se as fórmulas da sexuação fossem uma forma renovada de sustentar que o homem só se constituiria a partir da negação da mulher. Nesse caso, tais fórmulas teriam sido compostas a partir da perspectiva do homem. Dai pensar-se "todo"; e, em referência a isso, a mulher é "não todo". Se as fórmulas não tratam de anatomia nem gênero; se a diferença sexual em Lacan é só formal, sem conteúdo; ainda assim, "por que cabe às mulheres o lugar do "não todo", já que apenas se trata de um affaire lógico?" (ARÁN, 2009, p. 661). “A mulher não existe”, nessa perspectiva sociologizada, seria indício da submissão da mulher ao macho dominador.

Em outro momento, Arán afirma:

[...] o que propicia uma abertura nessa fórmula fechada do universal ou do simbólico é exatamente o fato de o lado feminino ser "não todo". Porém, para sustentar essa abertura, que garante, ao mesmo tempo, um limite ao simbólico e um acesso ao gozo, é necessário pressupor que "a mulher não existe". (ARÁN, 2009, p. 600)

Será mesmo que o universal, lado homem, fechado, para que se constitua como tal, como um conjunto com limites, necessita que a mulher seja posta de fora? Além do mais, há um pressuposto espinhoso aqui, subterrâneo, que atrela homem a 
simbólico - já vimos como a leitura de Schepherdson tenta dessociologizar o registro simbólico. Retornando a Arán: para que o lado homem tome forma, a mulher deve ser excluída. Por outro lado, são numerosas as vezes que Lacan marcou que, para que o homem como tal exista, não é condição sine qua non - nem contraponto - que a mulher não exista: é necessário o 'ao menos um', justamente o que faria A mulher existir. Além do mais, a nosso ver, o universal e o simbólico não são "fórmulas fechadas": o universal comporta uma exceção e falta o significante que daria consistência ao simbólico.

Se a mulher é não toda fálica, isso quer dizer que ela esteja excluída do universo simbólico? Não,

ela tem um lugar negativo (porque não fixo) na ordem simbólica [...], não todo se refere ao fato de que nenhum sistema de representação é completamente totalizante ou inclui tudo nele, porque abriga o reconhecimento de sua própria limitação, mesmo que pretenda se furtar a esse saber traumático. (BRONFEN in SALECL, 2000, p. 178; trad. nossa)

Desconfiamos dessa ideia de que é a mulher o que proporciona uma abertura intrínseca ao registro simbólico. Ela aponta para uma forma específica de se relacionar com a função fálica, para além da permitida pela lógica que rege o lado esquerdo das fórmulas; mas daí deduzir que isso traz consequências para a forma como o simbólico é estruturado nos parece uma passagem rápida demais.

Bronfen (in SALECL, 2000), oferecendo sua interpretação da sexuação lacaniana, pensa que a função fálica prescreve um limite exclusivo. O gozo feminino estaria fora do mapa das representações, como que prescrito por uma lógica de exceção. Isso promoveria a promessa de um gozo sexual ilimitado? Não, o gozo feminino, ao contrário do fálico, é assexual, já que aponta para uma posição além da lei prescrita pela castração simbólica. Trata-se de um gozo assexual, asexual? Bronfen (in SALECL, 2000) considera o outro gozo como fora do sexo ou do saber sexual; consequentemente, não regido pelo falo. Tal leitura levanta a questão a respeito do estatuto do Outro gozo — se seria próprio ou ainda seria "dependente" do falo. Fink apresenta outra versão: para ele, esse tipo de gozo assumiria um lugar dentro da ordem simbólica, mas permaneceria inefável.

Fink (1998), quanto às fórmulas, propõe pensar x como gozo. Lado 'mulher': não todo gozo dela é fálico, mas não há nenhum gozo que não seja fálico. $\mathrm{O}$ 
foco cai no verbo 'haver', 'existir'. "Todo gozo que existe é fálico, o que não quer dizer que não possa haver alguns gozos que não sejam fálicos — é que eles não existem: ele ex-sistem" (FINK, 1998, p. 39). Interessante essa ideia de que gozo fálico e Outro gozo não possam ser pensados, na mulher, desatrelados, já que o Outro gozo ex-siste, sendo a sua parte que existe vinculada ao falo.

Por que Outro gozo com O maiúsculo? Porque, para Fink, não se trata de qualquer significante, mas do $S_{1}$, o significante unário, o que permanece radicalmente Outro, diferente dos outros significantes. Enquanto o $S_{1}$ (o "não" do pai) funciona para o homem como um estabelecedor de limites, “o $S_{1}$ é um 'parceiro' eletivo para a mulher - sua relação com ele a possibilita ultrapassar as fronteiras estabelecidas pela linguagem e a escassez do prazer que a linguagem permite. Um ponto final para os homens, o $S_{1}$ serve como uma porta aberta para as mulheres" (FINK, 1998, p. 135). Adiante, Fink (1998, p. 143) sugere que o S(A), que é designado de diversas formas ao longo da obra de Lacan, pode constar, ou ser representado, como o significante da primeira perda, a perda do desejo do Outro materno, necessária para a instituição da ordem significante, tendo, portanto, o status de significante que estabelece o limite entre o simbólico e o real - algo tem que ser excluído, $\mathrm{S}_{1}$, para que o conjunto se constitua. Então, é como se essa perda ou exclusão real encontrasse um significante. Curioso: o que pode vir a acontecer se uma faceta do real, insignificável, encontrar um significante? $\mathrm{O}$ objeto pode ser elevado à dignidade da Coisa, como se este encontrasse, num encontro fortuito, um significante, como Deus ou Arte? De toda forma, pensar que o Outro gozo ex-siste põe em questão seu regime de existência, atrelado ao fálico, mas não numa relação que implique simples negação, exclusão ou submissão - talvez aqui possa se pensar numa relação discordancial, não foraclusiva, já que não se passa para outro registro. Tratar de 'homem' e 'mulher' a partir do $S_{1}$ de cada um também contribui para nos esquivarmos de repisar um tipo de relação hierarquizada entre eles.

Passemos à inspirada interpretação das fórmulas da sexuação feita por Zupancic (in SALECL, 2000), que nos permitirá tratar dos conjuntos 'homem' e 'mulher' sob os termos 'finito' e 'infinito'.

O lado 'homem' das fórmulas da sexuação traz um paradoxo: existe um que não se submete à função fálica, ao mesmo tempo em que todos se submetem a ela. A constituição do todo tem como condição sua exceção. Cabe apontar que não se trata do 'todo' mais o 'um' da exceção, com algo a ser adicionado ao conjunto, mas algo que 
tem de ser subtraído dele para que se constitua como conjunto - e tais eventos são contemporâneos.

Como meio de ilustração, a exceção funciona como uma chapa ou folha perfurada: o buraco a partir do qual olharíamos. Daí nunca ser possível olhar o todo, mas somente fragmentos da realidade. $O$ todo em Lacan não corresponderia a uma totalidade englobante. "Tudo o que aparece através do buraco, aberto com o Um-amenos da exceção, é passível de desejo" (ZUPANCIC in SALECL, 2000, p. 284).

Para Zupancic, há três condições: as duas fórmulas, a de cima e a de baixo, devem ser lidas juntas; o todo deve recair sobre a função de desejabilidade; a totalidade deve ser concebida não como uma totalidade englobante, mas como uma forma de sucessividade, uma série. O todo, o lado 'homem', não é incompatível com a ideia de não todo ou infinito - e não por conta do efeito que o lado feminino não todo poderia ter sobre o lado homem. Tratar-se-ia de uma "totalidade aberta: apesar do fato de que tudo que aparece através do buraco da exceção ser passível de ser desejado, ele nunca é todo, daí a série poder ser sempre contínua" (ZUPANCIC in SALECL, 2000, p. 284). Aqui uma exceção, não uma exclusão. A exceção não é excluída da série, mas participa do mecanismo da criação do todo que cai sob certas condições. E a exceção não é necessariamente a mulher, não deriva do lado feminino nem depende dela, mas sim do que, do lado 'homem', não existe. O que contraria o argumento de Arán e DavidMénard de que o conjunto do homem, para se constituir, exige a exclusão da mulher.

O homem só pode se dirigir ao outro sexo uma por uma (ou parte por parte), como numa aproximação serial - o que não se deve ao fato de que a mulher não exista ou que ela seja não toda, mas sim a uma característica da lógica do desejo que rege a posição ‘homem', essencial, por sinal, ao seu movimento metonímico.

A instituição da exceção faz com que o conjunto "todo" possa ser passível de ser "excepcionalizado", ou seja, o que pode ser visto através do buraco é encarado como uma exceção. Desde que caia sob certas condições, ela pode ser vista como uma exceção e entrar na série. Ou seja, no final das contas, entra como "o mesmo", já que respeita tais circunstâncias para fazer parte da série - uma mulher seria "especial" porque entra na série.

O universal particularizado é um conjunto do todo que é constituído pela operação de subtração do Um, que funcionaria como seu suplemento; a singularidade universal opera através da inclusão do Um, operação que tornaria o conjunto infinito: não é que o infinito seja imanente ao finito, "é a exceção que se torna imanente ao todo 
do finito e, consequentemente, introduz uma abertura nesse finito, tornando-o não todo, tornando-o infinito" (ZUPANCIC in SALECL, 2000, p. 289).

Se, para Lacan, de acordo com Zupancic (in SALECL, 2000, p. 290), o gozo feminino é o "gozo definido como o infinito inacessível dentro do qual o processo de determinação do gozo castrado opera", para ela o infinito (ou o mal infinito, aproximando-se sem fim do limite e sendo constituído através da exclusão de um ponto virtual do universo finito), deve ser pensando do lado 'homem'.

Exemplo disso é a leitura de Zupancic da fábula de Aquiles e a tartaruga, que Lacan aborda no Seminário XX, na qual aponta que Aquiles só alcançaria a tartaruga no infinito. Aquiles só pode ultrapassá-la: com seus pés finitos, ela permanece inacessível a ele. Tal fábula, para Zupancic, não seria uma alusão à máxima A relação sexual não existe, nem a tartaruga é uma representação da mulher. O que é inacessível para Aquiles não é o gozo feminino, mas o gozo não castrado. A tartaruga representa o ponto de exceção que promove a subjetivação correspondente ao lado 'homem'. A tartaruga é o objeto $a$. É só dele que o homem pode se aproximar, não da mulher: o gozo fálico é um obstáculo ao homem poder gozar do corpo de uma mulher, já que ele se limita ao gozo do órgão. 1+1 não é 2 , mas permanece duas vezes 1 - tal inacessibilidade é relacionada ao conceito de alef zero. "2" pode ser pensado como o inacessível infinito, ou como o Outro inacessível.

Quanto à mulher, o "2" pode ser um ponto de partida, permitindo a ela se relacionar com o Outro de duas maneiras. "Se ela fosse limitada somente a uma relação com o falo, ou seja, se ela adentrasse somente o campo do desejo, ela seria tão completa (toda) como um homem na sua relação com o objeto $a$. Mas ela, em primeiro lugar, tem uma relação com o Outro $(\rightarrow S(A))$. [...] Paradoxalmente, a mulher é Um com o Outro, e é exatamente isso o que a torna não toda” (ZUPANCIC in SALECL, 2000, p. 293).

Retomando a fábula. O enunciado "Aquiles só pode passar a tartaruga" cabe ser pensado como uma das formas de fazer alegoria d'A mulher. Só pode passá-la, porque alcançá-la, só no infinito. Parece, aqui, que Lacan atribui caráter existencial axiomático ao infinito.

Ora, a partir do momento em que vocês estão diante de um conjunto infinito, vocês não poderiam estabelecer que o 'não todo' comporta a 'ex-sistência' de alguma coisa que se produza de uma negação, de uma contradição. Vocês podem, a rigor, vocês podem estabelecê-lo como de uma existência inteiramente indeterminada (LACAN, 197273/2010, p. 221). 
Ou seja, não é a existência de um conjunto infinito que Lacan está negando, mas sim a consequência existencial de uma exceção ao nível deste conjunto que ele denomina não todo. Não é a existência do não todo que está em jogo, mas a existência da exceção ao não todo. Nesse conjunto infinito, é possível retirar ou adicionar partes partes, não elementos - e sempre será possível chegar ao mesmo conjunto inicial. Não todo x é submetido à função fálica: isso não que dizer que há um que não seja castrado, como no homem, mas que o não todo não pode ser deduzido a partir da existência de um que é produzido pela operação de negação. Não há exceção, já que estamos lidando com o infinito, levando em conta o tipo de infinito ao qual Lacan se refere. 'Não todo' como próximo de 'singularidade universal': não há um, exceção, para quem a função fálica não se aplique; mas estamos aqui no infinito, então não há totalidade do campo. Não se acessa, ou se deduz o outro gozo negando o gozo fálico (a negação sustenta o gozo fálico e o mantém no terreno do finito) — ou seja, não se deduz o feminino do masculino.

É somente do lado 'mulher' que a castração se aplica sem exceção, enquanto perde toda a referência ao "todo". Ao se tornar universal, a função de castração se torna não toda. Como não toda, ela suporta adições, subtrações e gozos suplementares. Para Zupancic (in SALECL, 2000), o que definiria o gozo feminino é sua possibilidade de assumir um suplemento (ou um déficit) de gozo sem perder sua referência à castração, enquanto o gozo fálico sempre se atém a ela. Importante levar em conta que o termo infinito não se refere a algo tão grande ou intenso que não haveria palavras para falar dele, não diz respeito a uma qualidade ou quantidade. Deve ser levado em conta seu sentido na matemática: “o infinito é o que diz 'não' à exceção do finito" (ZUPANCIC in SALECL, 2000, p. 296).

Barnard (in BARNARD; FINK, 2002) inclui nessa discussão a respeito da sexuação a lei simbólica. Se do lado 'homem' a exceção corresponde à fantasia masculina de transgressão à lei, do lado 'mulher' o não todo da mulher "denunciaria" que a função de ancoragem do significante fálico é contingencial, revelando a impotência da lei. O sujeito feminino habitaria o simbólico não como ausência, mas como um modo de presença que emerge desde "além do véu" da presença fálica — ela estaria alienada no simbólico, mas estabeleceria outra relação com seus limites.

Homens e mulheres estabelecem relações específicas com o infinito: no caso deles, o infinito está em prol da produção do conjunto finito; do lado 'mulher', o 
infinito impõe um limite à produção contingencial da lei, infundindo algo novo e que se furta ao circuito repetitivo pulsional. No caso, seria a relação que se estabelece com o Outro via $\mathrm{S}(\mathrm{A})$ o que aponta para a contingência e falha da lei. A estrutura feminina denuncia que a consistência do simbólico é afetada pelo real. Então, para que o simbólico, do lado 'homem', possa se constituir, algo não simbolizável deve funcionar como exceção ao conjunto - um externo é necessário. E do lado mulher, a sua configuração derivaria não do que estaria fora, mas do que haveria dentro. Um significante mestre que viria de dentro e que seria produzido através da contingência. "No gozo feminino, o real encontra-se com um significante" (BARNANRD in BARNARD; FINK, 2002, p. 179).

Ainda segundo Barnard (in BARNARD; FINK, 2002), nesse momento mais avançado da obra de Lacan, a recorrência à teoria dos números e dos conjuntos, à topologia e, por fim, à teoria dos nós põe por terra a forma geográfica plana e binária que formata o sistema de pensamento ocidental - o que permite revigorar o entendimento da diferença sexual. A estrutura seria não homóloga, a relação de causalidade comum seria subvertida: a banda de Moebius, por exemplo, confunde o dentro com o fora, estabelecendo uma relação circular não recíproca. Nessa perspectiva, Lacan passa a pensar o corpo não através da geometria euclidiana, mas no decurso de outras figuras topológicas; e, nessa reformulação, traz novidades para se pensar a sexualidade feminina - proposta essa também levada a cabo por Irigaray. O imaginário e o simbólico não dão conta do corpo. Há o real, o que faz com que o corpo ex-sista em sua pretensão de materialidade e inscrição em termos sexuais: há algo do corpo que não é sexualizável, o ser da letra, que não se atrela à significação e aponta para o Outro gozo, não fálico. A mulher ex-siste ao simbólico e está ao alcance da letra. Nessa vertente, Barnard sustenta a ideia de que as fórmulas da sexuação escrevem as formas masculina e feminina com que os sujeitos se relacionam com o real, "como as estruturas masculina e feminina são - cada uma à sua maneira - uma manifestação do sujeito como uma resposta desde o real" (BARNARD in BARNARD; FINK, 2002, p. 176). O sujeito seria uma resposta, masculina ou feminina, ao real. Nessa perspectiva, homem e mulher não seriam distintos enquanto sujeitos tomados como entidades específicas - o que os diferenciaria seria a particularidade de reação frente à irrupção do real e a forma com que a lei intervém em cada um deles.

Safouan (2009) defende que há um saber flutuante a respeito do que seriam homens e mulheres: atributos, papéis e expectativas de gênero variam de cultura a 
cultura. O par de opostos homem/mulher é fabricado assim como outros o são: forte/fraco, par/ímpar, ativo/passivo. O bebê é designado como homem ou mulher, num primeiro momento, a partir da visão do seu órgão sexual. Contudo, dizer que um homem é um homem não encerra a questão; pelo contrário, o ato de nomeação subverte a realidade. Daí Safouan considerar que é a resposta frente ao desejo do Outro a respeito do pertencimento a esse ou aquele sexo que é passo decisivo: "a questão da diferença do sexo como uma questão de escolha entre desejo masculino e desejo feminino" (SAFOUAN, 2009, p. 52). E mais adiante: "as fórmulas da sexuação de Lacan [...] não concernem aos dois sexos, o sexo masculino e o sexo feminino, mas a seus desejos". Safouan considera que um indivíduo do sexo masculino pode ter um desejo de tipo feminino, e vice-versa. Ao contrário da assunção acrítica e cegamente normativa do sexo, tal como certas feministas consideram que a psicanálise opera, "a questão é: como um sujeito masculino ou feminino pode vir, ou não, a adotar uma posição em conformidade com seu sexo biológico?" (SAFOUAN, 2009, p. 58). Posição essa que, para Safouan, diria respeito a um tipo de desejo, masculino ou feminino; e que, a nosso ver, se tem o mérito de desviar o sexo de determinações biológicas, alimenta um essencialismo dualista do qual Lacan sempre se esquivou. Ragland-Sullivan (2004) também adotaria essa postura de opor dualidades.

Existe toda uma crítica a respeito da leitura que certas feministas empreenderam dos registros lacanianos, e tais críticas também devem ser estendidas à forma com que certos psicanalistas os leram. Ellie Ragland-Sullivan é uma das principais vozes do lacanismo em solo norte americano; além de estabelecer um longo debate com os estudos de gênero, tem lugar central na difusão do pensamento de Lacan.

Para Ragland-Sullivan (2004), as identificações masculina e feminina não são determinadas pelo sexo anatômico nem por significantes, o que faz deles um enigma. A entrada na linguagem faz do sexo em psicanálise um tema marcado por perda, falha, descontinuidade e indeterminação. $O$ inconsciente não opera por harmonias: "além disso, ele [Lacan] critica o Um como ideal, ou o ideal do casal heterossexual harmonioso, [...] dado o desenvolvimento dissimétrico de homem e mulher no nível da identificação e da relação a uma lógica do todo e do não todo" (RAGLAND-SULLIVAN, 2004, p. 32). Tais lógicas, todo e não todo, "categorias irredutíveis ao gênero" (RAGLAND-SULLIVAN, 2004, p. 125), não seriam complementares. 
Ragland-Sullivan (2004) considera que as lógicas intrínsecas à sexuação pretenderiam dar conta de como as identificações são construídas; tratar-se-ia de uma suposta identificação sexuada masculina ou feminina. Essa tese também seria sustentada por Miller, estabelecida a partir, primeiramente, com referência ao falo entendido como significante da diferença sexual, um significante sem significado, e que agrega valor a determinados traços (RAGLAND-SULLIVAN, 2004, p. 105). A autora opõe identificações, contrasta simbólico e real, amar e ser amando e o saber referente ao gozo no tratamento de homem e mulher. Também considera que a sexuação comporta uma diagnóstica própria. Quanto aos registros:

Como não há o universal da Mulher [...], os traços femininos [...] não se tornam significantes abstratos ou princípios que garantam a lei da ordem simbólica, como faz o pai primevo do lado masculino. $\mathrm{Na}$ lógica feminina, a dupla negação cria uma dupla função não inscritível — ou seja, o real. (RAGLAND-SULLIVAN, 2004, p. 44; trad. nossa)

Ragland-Sullivan faz uma associação entre simbólico e lógica masculina (todo), por um lado; e real - sinônimo de modalidade do impossível para ela - e lógica feminina (não todo), por outro. O feminino, real, escaparia das regras do simbólico, em parte; enquanto a identificação masculina, ao contrário, tenderia a se esvair do real. "O feminino, pelo contrário (em relação ao masculino) é constituído pela lógica não toda enclausurada na ordem simbólica" (RAGLAND-SULLIVAN, 2004, p. 147). Em outro momento: "o masculino se identifica predominantemente com a ordem simbólica da linguagem e com as convenções sociais, enquanto o feminino se identifica com o real do afeto, perda e trauma" (RAGLAND-SULLIVAN, 2004, p. 179) - real esse "repleto de segredos de agonia e êxtase, um reino de conflito, excitação, descontinuidade, e impasses desarmoniosos" (RAGLAND-SULLIVAN, 2004, p. 183).

Ragland-Sullivan, assim como boa parte das feministas que se verteram a Lacan, procede, de forma contestável, atrelando o simbólico à identificação masculina e o real e o trauma ao feminino, partindo de um processo predicativo dos registros.

Outra tese defendida por Ragland-Sullivan (2004, p. 75) é que Lacan teria traduzido as duas posições freudianas, ativo-homem / passivo-mulher, em amante e amada — homens amam, mulheres são amadas —, mesmo que isso não configure uma totalidade, dados os impasses próprios à não relação sexual.

A psicanalista norte-americana considera que a sexuação lacaniana pode trazer elementos diagnósticos para a clínica psicanalítica, sem que se baseiem em 
comportamentos sexuais. O elemento que serviria como critério diagnóstico seria a interpretação dada ao sujeito do inconsciente a respeito da diferença sexual, mas não aquela depurada da percepção dos órgãos sexuais. Quatro possibilidades: neurose, perversão, psicose e mascarada normativa. Para Ragland-Sullivan (2004, p. 143), as estruturas de desejo a partir das quais a sexuação seria dedutível se ergueriam a partir de quatro situações. A produção de um desejo "normativo", baseada numa forte crença em um Nome-do-Pai e na repressão do inconsciente; a neurose, que nega a diferença sexual que funda o inconsciente; a perversão, que repudia a diferença; e a psicose, que a foraclui. Ragland-Sullivan (2004, p. 85) também aponta, em outro momento, que essas seriam quatro atitudes possíveis frente ao falo: o significante fálico é negado na neurose, foracluído na psicose, fetichizado na perversão, ou temos o abafamento normativo da diferença que caracteriza a mascarada construída para se moldar socialmente. Cabe apontar que, para Ragland-Sullivan, o falo é o significante da diferença sexual.

Outra contribuição que a autora (RAGLAND-SULLIVAN, 2004, p. 31) vê na sexuação é que, nesse modelo teórico, mesclam-se sexualidade e epistemologia. Lacan também teria pensado 'homem' e 'mulher' a partir de lugares epistemológicos estabelecidos como respostas masculina ou feminina à falha ou à perda. A diferença sexual também se revelaria em diferentes formas de saber: "as fórmulas da sexuação que conectam a sexualidade a modos de saber" (RAGLAND-SULLIVAN, 2004, p. 62). Lacan, no Seminário XXI, fala em "saber masculino", inclusive.

Ragland-Sullivan afirma que, se a masculinidade e a feminilidade possuem conteúdos incertos, Lacan teria demonstrado como tais conteúdos são formatados logicamente em uma estrutura predicável, e dá seu recado ao feminismo:

E como tais estruturas são a-históricas no sentido do universal, determinando, antes, posições de saber de gozo na linguagem, não o saber enquanto conteúdo, é crucial a todo feminismo considerar que, apesar dos atributos que caracterizam as especificidades do masculino ou feminino variarem de um momento histórico a outro, a lógica que rege sua dissimetria permanecerá constante. (RAGLANDSULLIVAN, 2004, p. 79; trad. nossa)

Nesse sentido, Ragland-Sullivan considera uma limitação o feminino, por exemplo, ser reduzido ao "performativo, referido ao poder sociológico pelo construcionismo histórico foucaultiano" (RAGLAND-SULLIVAN, 2004, p. 133). A importância de se voltar para a lógica moderna é que esta desloca homem e mulher de suas atribuições, o que faz pensarmos se gênero também pode ser tratado assim, para 
além de aspectos atribuídos a 'homem' e 'mulher' em termos de oposições binárias — gênero só pode ser um aglomerado de atributos em atuação ou significantes a serem confrontados?

Por fim, para Ragland-Sullivan, a oposição entre masculino e feminino não é binária. O significante fálico, como terceiro termo, organiza toda uma dialética do desejo em torno daqueles elementos. Não há binaridade porque há uma dissimetria entre os sexos. Como não há a representação de 'homem' e 'mulher', eles não têm como ser postos numa relação dialética que implique em oposição dos termos: "isso significa que o masculino e o feminino não são simples binários, coleções intercambiáveis de palavras e letras que constituem um logos, tal como argumentava Derrida" (RAGLAND-SULLIVAN, 2004, p. 66).

Essa questão da binaridade é alvo de longa discussão em Le Gaufey (2007).

Nunca é demais mencionar que, na teoria da sexuação, exprime-se uma confrontação, antiga em Lacan, entre ser e existência. A inexistência da relação sexual prevê desessencialização, já que inclui nela um universal inconsistente; e, do lado da universal consistente, não se instaura nenhuma existência - a particular afirmativa indicaria uma essência, consequentemente. Nesse percurso, Lacan procura uma existência sem essência na forma do objeto $a$ e para os desdobramentos do seu famoso aforismo 'não há relação sexual'. Para Le Gaufey, o não todo e o gozo feminino não devem ser encarados como essências do feminino.

Le Gaufey aponta para a importância de se distinguir 'diferença', contrário de 'identidade', de 'próprio', contrário de 'impropriedade'. 'Diferença' diria respeito, por exemplo, ao fato de que um dos lados, 'homem', apresentaria traço fálico, tendo correspondência com o outro, 'mulher', pela sua ausência de traço: homem e mulher seriam contrapostos a partir de um único elemento. $O$ que nos faz lembrar dos quadrantes de Peirce, para se pensar o lado 'mulher'. Ao levar em conta os dois quadrantes superiores, podemos afirmar que "todo traço é vertical", mas temos um subgrupo vazio - é como se esse universal carregasse em si um conjunto vazio. Temos uma presença adicionada à possibilidade do vazio ${ }^{36}$.

Já quanto ao 'próprio': o que seria próprio do homem não seria o mesmo que qualificaria a mulher como tal - temos dois elementos distintos. Ao negar 'homem', passamos para o lado 'mulher'; mas, ao negar esse lado, nada garante que

\footnotetext{
${ }^{36}$ A descrição de Lacan do esquema de Peirce, no contexto da composição da teoria da sexuação, se dá a partir da página 64 do Seminário XVIII (LACAN, 1971/2009).
} 
voltemos para o lado 'homem': "se, de fato, nego a presença de um traço dado, obtenho sua ausência; mas se nego sua ausência, como posso saber se volto a reencontrar esse traço ou qualquer outro, ou nada em absoluto" (LE GAUFEY, 2007, p. 134). O que não está de um lado não está necessariamente no outro - isso só ocorreria se 'homens' e 'mulheres' fossem dois subconjuntos de um mesmo conjunto. Dessa forma, Lacan quer rechaçar o dualismo, qualquer ideia de complementariedade entre 'homem' e 'mulher', na qual se sustentava, por exemplo, a psiquiatria clássica - que encarava homens e mulheres como complementares, ao adotar o modelo biológico e heterossexual da reprodução - , abrindo um campo que funcione a partir de outro mecanismo. Pode-se pensar a diferença a partir de um ponto comum, mas sem simetria ou relativizações, o que não nos obriga necessariamente a adotar o recurso de contrapor "próprios" específicos ou dois universais.

[...] supondo que todos dizem 'sim' (todo x phi de $\mathrm{x}$ - por notação) e que não há ninguém que diga 'não' (não existe $x$ não phi de $x$ ), aqueles que dizem 'não' (existe $\mathrm{x}$ não phi de $\mathrm{x}$ ) e aqueles que dizem 'sim' (não todo $\mathrm{x}$ phi de $\mathrm{x}$ ) vêm a esquivar-se duplamente dos enunciados universais que pretendem governá-los. (LE GAUFEY, 2007, p. 145)

Do lado direito, Lacan afirma que não há exceção, o que impede que os que existem formem um todo; e, por outro lado, faz com que nenhum elemento escape do não todo - aqui no lugar da particular negativa. Tal proposição também pode ser contradita pela universal negativa (não existe um que não), o que, por sua vez, leva a universal a não funcionar como uma clausura. Para Le Gaufey, se em ambos os lados o particular contradiz o universal, também um lado objeta o outro - na medida em que um afirma a existência, enquanto o outro a nega. Assim Lacan foge da coletivização que levaria à essência dos dois lados, indicando a falta parcial do universal. Não temos em ambos os casos uma totalidade englobante que apontaria para uma unidade compacta e homogênea: sempre há algo que não se inclui no universal.

As quatro proposições se sustentam juntas quando nos referimos àquele quadrado lógico da sexuação, oriundo dos quadrados lógicos das proposições da particular máxima e da particular mínima, como quer Le Gaufey ${ }^{37}$. O importante é que no quadrado - que não funciona por uma mera oposição de fatores, mas também a partir de outras maneiras de se estabelecer relações — há um movimento de escritura específico entre as quatro fórmulas de cada quadrado e as relações entre as fórmulas são

\footnotetext{
${ }^{37}$ Tais quadrados se encontram escritos na orelha deste livro de Le Gaufey (2007), El notodo de Lacan.
} 
de contrariedade, compatibilidade, explicação, contradição e equivalência. As quatro fórmulas podem ser lidas como compondo um conjunto: "convém, pois, aproximar-se de outro modo de consistência global do conjunto dessas quatro fórmulas, se pretendermos evitar a armadilha de lê-las como escrituras de fundo dualista" (LE GAUFEY, 2007, p. 107).

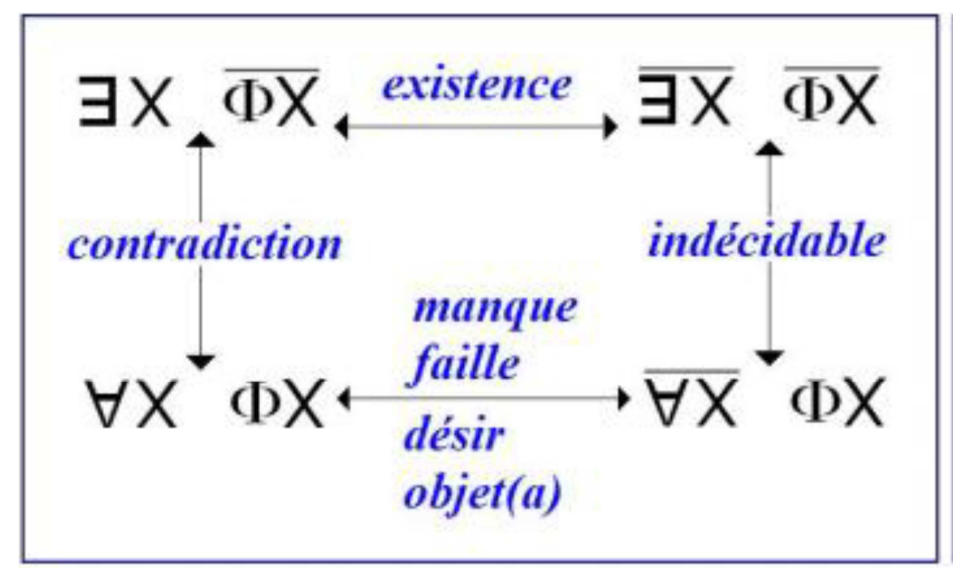

Se o quadro lógico aristotélico revela certa simetria, já que a particular afirmativa está de acordo com a universal afirmativa, contradizendo a universal negativa, Lacan tende a se focar mais no lado direito, priorizando o não todo. Le Gaufey (2007, p. 144) chega a afirmar, inclusive, que o fato de a particular afirmativa entrar em contradição com a universal afirmativa se deve à afirmação anterior do não todo - o não todo, como particular negativa, nega a universal afirmativa, permitindo a particular afirmativa. O não todo, particular negativa, na leitura que Le Gaufey empreendeu da proposição lacaniana, contesta tanto a universal afirmativa quanto a negativa, esvaziando seu caráter ontológico. Mas o que está pressuposto aqui? Que as quatro proposições funcionam em conjunto.

Lacan, ao descrever a relação entre as quatro proposições, aponta: "Agora, a questão é saber como, em meio a tudo isso, funciona algo que possa assemelhar-se a uma circulação" (LACAN, 1971-72/2012, p. 199) - circulação cujo movimento pensamos que Lacan tenha esboçado:

Quanto àquilo que necessita da existência, partimos da hiância do indecidível, entre o não todo e o não uma. Depois disso, isso chega à existência. E então, depois disso, chega ao fato de que todos os homens estão em poder da castração. Isso chega ao possível, porque o universal nunca é outra coisa. Quando vocês dizem que todos os homens são mamíferos, isso quer dizer que todos os homens possíveis 
podem sê-lo. E depois, isso vai para onde? Vai para o objeto $a$. É com o objeto $a$ que nos relacionamos. E em seguida, vai para onde? Vai para onde a mulher se distingue por não ser unificante. Já não resta senão completar aqui, para voltar à contradição e voltar ao não todas, que, em suma, não é nada além da expressão da contingência. (LACAN, 1971-72/2012, p. 202)

Em outra perspectiva, este 'existe um que diz 'não', Lacan acrescenta às outras três fórmulas: 'todo'; 'não existe x que não' — “não é verdade que seja a função fálica que domina a relação sexual", ou não é verdade que a função fálica domine o que concerne à relação sexual, não há nenhuma mulher que se oponha a isso; e a função do não todo, que prevê um tipo específico de relação com a função fálica. As quatro proposições poderiam ser encaradas como um único conjunto. "É isso que faz das quatro inscrições um conjunto" (LACAN, 1971-72/2012, p. 195). As posições 'homem' e 'mulher' seriam parte do mesmo conjunto, ou do mesmo sujeito: "O conjunto nada mais é que o sujeito" (LACAN, 1971-72/2012, p. 198) - cumpre lembrar que o conjunto vazio é um elemento do conjunto. O sujeito poderia, assim, passar de uma posição, 'homem' ou 'mulher', à outra. As fórmulas poderiam ser lidas como um movimento circular intrínseco — em potência, pelo menos - a todo sujeito. Qualquer sujeito poderia circular em ambos os lados. Tal leitura seria mais um argumento contra a ideia de que as fórmulas são binárias por opor radicalmente homem e mulher; nessa perspectiva, as fórmulas não se pautam em duas posições, identificações, atitudes ou inscrições.

Se é o mesmo x que se escreve de um lado e do outro — não é x e y —, trata-se do mesmo ser falante lidando com o mesmo elemento, enfrentando o gozo que se liga à linguagem. A bipartição sexual resultaria, então, de disposições enunciativas, numa "perspectiva performativa”, tal como afirma Le Gaufey (2007, p. 188): “o $x$ que se excetua do todo em que se é colocado como o lugar de seu pertencimento será chamado 'homem'; o $x$ que existe sem pertencer a nenhum todo será chamado 'mulher"'. Se os dois lados podem ser acessíveis a todos os sujeitos, seria um caráter performativo — ou de nomeação — da sexuação a diferenciá-los em homem e mulher ${ }^{38}$. A declaração de Le Gaufey parece prever a possibilidade da passagem do gozo ao semblante.

\footnotetext{
${ }^{38}$ Aqui Le Gaufey considera que, na fantasia do homem, atribui-se um aspecto imaginário ao 'ao menos um', a partir do que 'cada um' dos homens faria performaticamente exceção. Já do lado 'mulher', como não há todo, 'cada uma' não é bem 'uma', estando ou em excesso ou em falta com relação à unidade: "por esse motivo é que nenhum valor, nem simbólico nem imaginário, será correto para qualificar um elemento, na medida em que nenhum será idêntico a si mesmo" (LE GAUFEY, 2007, p. 186).
} 
De toda forma, se as fórmulas partem do universal, elas também o fazem esmorecer num local preciso,

\begin{abstract}
desconstruindo o par de oposição sexual que, num primeiro momento, tinha servido para construí-las. Todo o ardil radica em fazer com que esse desequilíbrio não gere nenhuma simetria, que esse traço presente à esquerda (que funda a totalidade) e sua ausência de traço à direita (que obriga ao não todo) não compartilhem nenhum espaço já delimitado. (LE GAUFEY, 2007, p. 137; trad. nossa)
\end{abstract}

Dissimetria: os conjuntos que não se pertencem a si mesmos não podem ser contabilizados como o conjunto dos conjuntos que pertencem (LE GAUFEY, 2007, p. 140).

A composição, tanto do lado esquerdo quanto do direito, se dá a partir da exceção: há exceção de um lado e não há exceção do outro. Seria esse elemento o que faria um lado oposto ao outro? Não, não se trata de um par de oposição simples, baseado na ausência ou presença de um elemento a ser tomado como exceção ou não. Não se trata de opor 'limitado' — no lado 'homem', a exceção decretaria o limite — a 'ilimitado' - não exceção, não limite. Um todo finito ilimitado (nenhum ponto funciona como limite) pode ser representado pela figura da esfera, sugere Le Gaufey (2007, p. 106), ao passo que o todo infinito limitado, pela reta real $[0,1]$. Os lados diferentes seriam representados por figuras incomensuráveis tal como contemplam limites e finitudes. Le Gaufey considera que Lacan quer, a todo custo, fugir do binarismo. Temos que nos lembrar das diferentes formas de negação (foraclusão e discordância), dos diferentes regimes de existência e da unilateralização do universal. Lacan não quer fazer de um todo a negação do outro, mas tratar do fato de um ser o obstáculo do outro - ou do que faz barreira entre eles. Lacan não estaria indo atrás de um traço pertinente que diferenciaria homem e mulher, mas do que impede um de ter acesso ao outro.

Os lados se sustentam na medida em que há um obstáculo entre eles. Procedendo assim, Lacan quer sufocar as dualidades homem/mulher, ying/yang, XX/XY, com membro/sem membro (LE GAUFEY, 2007, p. 114). Se a lógica que rege o gênero pressupõe uma articulação sem falha entre duas entidades distintas - na forma de masculino/feminino, por exemplo — , sem resto, as fórmulas da sexuação são regidas por uma lógica que não permite bipartições usuais e exatas que ponham em relação predicações essencializadas. Se "há uma homologia dos valores de verdades e a bivalência das posições sexuais entre as quais se repartem os humanos”, segundo 
David-Ménard (1998, p. 110), Le Gaufey (2007, p. 144) aponta que sempre há um resto - e, nesse caso, a falha sexual e a falha lógica se afetam mutuamente.

Por fim, a dualidade dos sexos pode ser pensada a partir da realidade anatômica, cromossômica, psicológica ou sociológica, tanto pela operação de oposição entre termos incompatíveis ou levando em conta o mesmo termo numa cadeia de relativos. A nosso ver - no que o discurso psicanalítico contribui para o tema -, nem uma nem outra, isoladamente: se, por um lado, podemos pensar que o homem quer fazer A mulher e a relação sexual existirem, o lado direito das fórmulas não o permite: temos um ponto em comum, a função fálica, mas dois funcionamentos lógicos incompatíveis. Temos dois elementos distintos, gozo fálico e gozo Outro, mas que não podem ser comparados ou tomados independentemente um do outro. Nenhuma relação pode ser concebida entre os sexos, nem de simples enfrentamento de elementos opostos nem de relativização entre um termo comum. A diferença é absoluta: ela é tão radical que impossibilita estabelecer qualquer tipo de relação entre os dois lados.

\subsection{Há-do-Um}

"Só a matematização alcança o Real."

— Jacques Lacan (1972-73/2010, p. 258)

Aqui pretendemos fazer uma incursão pelo tema 'homens' e 'mulheres' a partir dos números, o que traria subsídios para uma fundamentação matemática da não relação sexual ${ }^{39}$.

Focando este 'ao menos um' que se localiza do lado 'homem', Lacan afirma: "Observem o que está escrito à esquerda [...] o Фx com o sinal de negação em cima. Trata-se de que é na medida em que a função fálica não funciona que existe uma chance de relação sexual" (LACAN, 1971-72/2012, p. 101).

$\mathrm{O}$ ao menos um, hommoizin - que, em mito, goza de todas as mulheres - , faz dessa forma o universal da mulher existir. Nesse caso, ao lado do universal do homem haveria dualidade, dois sexos, e não um sexo e o Outro vazio. Só

\footnotetext{
${ }^{39}$ Cabe lembrar que tratar dos sexos a partir dos números não é exclusividade de Lacan. Já se lê em Fraisse (2010, p. 109): "Outra figura ilustraria a transformação possível do simples jogo da dualidade ou da binaridade dos sexos, [é] aquela da relação entre o particular e o geral. Aqui se encontra de fato uma das perversões do pensamento filosófico e do pensamento em geral, aquela que subsume o dois da diferença sob o Um sem respeitar cada parte".
} 
nesse nível, porque, para existir tal relação, dois universais, dois todos deveriam estar em jogo. Só que do lado direito das fórmulas temos um não todo: há uma divergência lógica no nível das universais. Quanto às existenciais, temos o 'ao menos um (1)', de um lado e a inexistência — não há um (zero) —, do outro. Ou seja, uma relação do 'um' com o 'zero' - dois no sentido de dois números. Nesse caso, só podemos falar de um sexo; ele só existe como um de um só lado; do outro, ele não existe: "O gozo, enquanto sexual, é fálico, isto quer dizer que ele não se refere ao Outro como tal" (LACAN, 1972-73/2010, p. 21). O gozo sexual é marcado por esse impasse, só sendo acessível pela via fálica. Em outros termos, o Outro está ausente.

[...] o desvanecimento da existência de um dos parceiros, que deixa um lugar vazio para a inscrição da fala, não é privilégio de nenhum lado. Só que, para haver fundamento do sexo, como se diz, é preciso que ele seja dois, Zero e um, isso certamente dá dois no plano simbólico, isto é, desde que concordemos que a existência se enraíza no plano simbólico. É isso que define o ser falante. (LACAN, 197172/2012, pp. 102-3)

Nessa citação vemos em que medida as fórmulas da sexuação são construídas como dois: elas operam com dois - 'zero' e 'um' são dois números. Tratase então de se pensar 'homem' e 'mulher' a partir do que se dá entre 'zero' e 'um'.

Para tratar do Um, Lacan recorre ao diálogo Parmênides de Platão, no que se distancia do 'um' em Aristóteles, ao conceito de número em Frege e à teoria dos conjuntos, forjando a expressão "Yad'lun" (LACAN, 1971-72/2012, p. 123). Há-um, contra a tese filosófica 'o Um é'. "Somos 'falasseres' [parlêtres], palavra vantajosa para substituir o inconsciente, porque joga com o equívoco da falação [partole], por um lado; e pelo fato de que é da linguagem que nos vem essa loucura de que há ser" (BADIOU; CASSIN, 2010/2013, pp. 28-9). Acompanhamos aqui o passo dado por Lacan na direção de um 'ser sem ser', contra a ontologia do ser aristotélico, na medida em que se encaminha ao ser da significância enganchado à escrita matemática e ao real.

Esse ser além da linguagem, nós pressentimos que ele só pode ser matemático, só pode ser número, e, a pretexto disso, imagina-se que se trate de quantidade. Mas talvez não seja ao número propriamente dito, em toda sua realidade, que a linguagem dá acesso. Talvez ele seja capaz somente de reter o zero e o um. Seria por aí que se fiaria a entrada desse real, esse real que é o único que pode estar além da linguagem, único domínio onde se pode formular uma impossibilidade simbólica. (LACAN, 1971-72/2012, p. 104) 
As coisas vão se passar para Lacan, a partir de Frege, na hiância entre o 'zero' e o 'um'. E quanto a esse 'um', Lacan adverte que ele não deve ser confundido com a tendência de Eros de que dois se fundissem em um — nas relações entre homens e mulheres, "nada se assemelha a não sei que tendência espontânea para o Um [...]". Nem com a mística de que o mundo tenderia ao Um: "não há nada mais perigoso do que as confusões quanto ao que vem a ser o Um" (LACAN, 1971-72/2012, p. 104). Com a lógica matemática e a teoria dos conjuntos, o 'um' pôde ser concebido para além desse sentido intuitivo e fusional - desatrelado, por exemplo, da ideia de que no amor se faz um. Esse tema foi amplamente tratado na filosofia e o discurso psicanalítico pode contribuir para ele - como não há relação, "Há Um e Um sozinho" (LACAN, 197273/2010, p. 143). Um inteiramente só, já que não faz relação com o Outro que passaria como o outro sexo. É somente na discórdia que se determina a ligação entre os sexos, já que 'homem' e 'mulher' não se instituem a partir de um universal.

O ‘zero' não é a negação do 'um', e sim “a verdade da falta que consiste em que em 2 falta 1. [...] Mas o que ele indica é que, quando é preciso haver 2, nunca há senão 1, e isso é uma verdade". O 0 que implica 1 não é sinônimo do falso que implica o verdadeiro, "mas como dois verdadeiros, um implicando o outro" (LACAN, 197172/2012, p. 169). O 0 tem uma relação tal com o 1 que não resulta em 2, o que só se revela no nível do alef zero, do infinito atual.

[...] quanto a tudo o que concerne aos números inteiros a partir de 2, não há nenhum número que não se possa produzir por uma dessas duas operações [adição ou relação exponencial], a partir de números menores que ele. Comecem no 3. O 3 se faz com 1 e 2. O 4 pode ser feito com um 2 elevado a sua própria potência. E assim sucessivamente. É justamente isso que falta no nível do 1, e é por isso que se produz no nível do alef zero essa falha de inacessibilidade. (LACAN, 1971-72/2012, p. 171)

Ou seja, não é possível se produzir números menores que 2 - o 'zero' e o 'um' não levam a ele: não há 'dois' que se gere por 0 e 1. Pra quê tudo isso? Para tratar da bipartição homem/mulher a partir de haver-um [d'lun].

Será que tudo que não é homem é mulher? Tenderíamos a admitir que sim. Mas, já que a mulher é não todo, por que tudo o que não é mulher seria homem? Essa bipartição, a impossibilidade de aplicar o princípio da contradição nessa matéria de gênero, que seja preciso nada menos que admitir a inacessibilidade de alguma coisa além do alef zero, para 
que haja consistência ${ }^{40}$ e seja pertinente dizer que o que não é 1 é 0 e o que não é 0 é 1 - isto é o que lhes aponto como sendo o que deve permitir ao analista entender um pouco além das lentes do objeto $a$, o que se produz de efeito, o que se cria de Um, por um discurso que repousa tão somente na base do significante. (LACAN, 1971-72/2012, pp. 171-2)

Entre 'zero' e 'um', numa reta orientada, cabe o infinito. Entre 'homem' e 'mulher' há um tropeço do princípio da não contradição. Para Le Gaufey (2007, p. 47), numa primeira leitura da passagem acima, de Lacan, 'homem' e 'não mulher' poderiam se equivaler, mas negar 'mulher' (ou seja, negar o (não homem)), não faz com que retornemos a 'homem', segundo a lógica intuicionista. Além disso, os dois sexos não compartilham o gênero, pensando extensivamente, de tal modo que tudo o que não se localizasse de um lado, se localizaria do outro. Lacan, nesse momento, trata de 'homem' e 'mulher' recorrendo ao número dos sexos e ao sentido lógico da contradição. Não há dois universais a se contraporem - 'zero' e 'um' não tem a consistência intrínseca a dois universais que se contradiriam.

O dois "não está fundido em Um nem o Um é fundado por dois" (LACAN, 1971-72/2012, p. 173), contra a fábula de Aristófanes em O banquete de Platão. Não há dois: não há relação sexual. 'Il y a d'lun', ou pior. Estamos aqui no Um de Parmênides, que não tem qualquer relação com Ser. A existência desse Um é matemática: um argumento, esvaziado de sentido, satisfaz uma fórmula, "é simplesmente o Um como Um" (LACAN, 1971-72/2012, p. 181).

"Está muito claro que não há nenhum meio de separar duas séries quaisquer - eu disse quaisquer - de atributos que componham uma série masculina, de um lado, e a série feminina, do outro" (LACAN, 1971-72/2012, p. 178). Ou seja, não nos detemos na oposição ou separação drástica entre gênero masculino ou gênero feminino. Lacan não está interessado em pensar 'homem' e 'mulher' a partir de atributos, ou como somatórios de identificação. Por exemplo, ele considera que equalizar 'homem' à atividade e 'mulher' à passividade — ou definir um ou outro a partir dessas qualidades, respectivamente - figura a "[...] inépcia do que é chamado de ativo, se é nisso que vocês se baseiam para distinguir o homem da mulher. [...] Não é tão evidente que na vida adulta, na vida normal, o ativo e o passivo se distribuam como nos dizem"

\footnotetext{
${ }^{40} \mathrm{Na}$ versão da Staferla, este "para que haja consistência" vem como "para que a não contradição seja consistente" (Seminário XIX, p. 110).
} 
(LACAN, 1971-72/2012, p. 179). Não há uma separação clara entre esses termos. Em outro momento:

Se algum dia vocês tiverem ouvido falar, pelo menos em nossa época, de um varão que o seja [que seja viril] mostrem-mo, porque isso me interessará. Se o homem é tudo o que vocês quiserem no gênero virtuose, virar a bombordo, virar por davante, virar o que você quiser, o viril fica do lado da mulher. Ela é a única a acreditar nisso. (LACAN, 1971-72/2012, p. 197)

A respeito da mulher, "castração quer dizer o quê? Quer dizer que tudo deixa a desejar, não quer dizer outra coisa. Para pensar isso, ou seja, pensá-lo a partir da mulher, é absolutamente necessário que haja um para quem nada deixe a desejar" (LACAN, 1971-72/2012, p. 200). É através do homem, na figura do Don Juan — aquele que não tem como ser submetido à privação, aquele que nada deixa a desejar —, que se tem a certeza do seu desejo pela mulher: é através do desejo desse homem, fantasia feminina, que ela acederia ao A mulher. "[...] A mulher não existe. A existência dela é um sonho de mulher, e é o sonho de que saiu Don Juan. Se houvesse um homem para quem A mulher existisse, seria uma maravilha, teríamos certeza de seu desejo. Isso é um elucubração feminina" (LACAN, 1971-72/2012, p. 70).

Referente ao Um, questiona-se sua existência: como pode haver Um? 'Existência' aqui não é sinônimo de 'essência': nós não somos um bando de 'uns', indivíduos como 'uns'. 'Il y a de l'un' teria como tradução literal 'Há algo de um': é importante destacar a função do partitivo em francês, o que denota que o 'um' tem partes. O Um tem caráter bífido, não é unívoco, e se distingue do Ser. Isso é crucial para dizer por que a existência gira em torno do Um, e não do Ser. Lacan vai se preocupar com "o que existe ao não ser" (LACAN, 1971-72/2012, p. 131), daí seu entusiasmo com o Um composto de partes.

A partir desse ponto, Lacan introduz a teoria dos conjuntos como contribuição aos desenvolvimentos das fórmulas no que tange ao 'existe' e ao 'não existe'. Avança-se com relação ao entendimento atributivo da classe, pois, com aquela teoria, há como se conceber o conjunto vazio como elemento - quando a classe se esvazia, não há mais classe. Trata-se do Um no registro da lógica dos números, ao qual o real estaria ligado, não da realidade natural ou material. Com Cantor, "o Um, que existe, do conjunto é distinto do Um do elemento" (LACAN, 1971-72/2012, p. 138). A classe, que se atrela ao atributo, pode proclamar a relação sexual; já a "função do 
conjunto, é que há Um distinto daquilo que, como atributo, unifica uma classe" (LACAN, 1971-72/2012, p. 181). Nas classes, pode haver uma correspondência biunívoca (cada um para sua cada uma), mas nunca nos conjuntos.

Conjunto tem elemento: ser um elemento num conjunto é ser algo que não tem nada a ver com pertencer a um registro qualificável de universal, isto é, a algo que se enquadre no âmbito do atributo.

Como forma de ilustrar a diferença entre classe e conjunto, acompanhemos Lacan ao falar em esfregões e guardanapos (LACAN, 1971-72/2012, p. 182). Em cada uma delas, esses objetos podem ter atributos diferentes, como "robusto", "duradouro" ou "barato" - aqui temos o Um como atributo, que só serve para definir uma classe. Contudo, num conjunto em que esfregões e guardanapos façam parte, o atributo não conta, nada distingue um esfregão do outro ou um guardanapo do outro: eles só valem enquanto ideia, "esfregões" e "guardanapos", daí concebermos que só existe 'um' aqui temos o Um como pura diferença. Então, no conjunto - tanto dos homens quanto no das mulheres - , seus atributos são desconsiderados, o que importa é a diferença que comportam entre si. Por isso falamos em diferença dos sexos. Interessa-nos pensar 'homem' e 'mulher' nessa perspectiva, e não na diferença atributiva das classes nesses termos, talvez aqui, ao lado das classes, possa ser pensada a estratégia do recurso ao gênero.

O Um da diferença funda o conjunto. Esse Um contado a mais se mostra, nesse existe, um que nega a função fálica. Esse Um (ao menos um) é o único elemento característico a fundar o homem. O próximo passo é conceber como, a partir dele, se chega ao não enumerável, ou à "impossibilidade de enumerar" (LACAN, 197172/2012, p. 138). O homem não é enumerável, um-a-um, com o uma-a-uma da mulher — todos os elementos do lado esquerdo que caem sob a função são submetidos à castração e temos um conjunto finito, com uma exceção. A existência desse negativo desempenha aqui o papel do limite, considera Lacan (1971-72/2012, p. 196). Nessa perspectiva, a teoria dos conjuntos faz, “[...] no que concerne aos homens, inteiramente finitos. [...] Quanto às mulheres, elas são enumeráveis" (LACAN, 1971-72/2012, p. 192). Já do lado das mulheres, o conjunto seria infinito e aberto — "o não todo não resulta de que nada o limite, porque nele o limite é situado de outra maneira" (LACAN, 1971-72/2012, p. 198).

O Um não se fundamenta na mesmidade, mas, com a teoria dos conjuntos, "na pura e simples diferença" (LACAN, 1971-72/2012, p. 139). Ele só é designado 
enquanto distinto, é relacionado com o alef zero e tem seu nascimento referido à passagem pelo conjunto vazio, "constitui-se do conjunto vazio cuja transposição é justamente aquilo de que o Um se constitui” (LACAN, 1971-72/2012, p. 141).

A teoria dos conjuntos concebe que um conjunto pode ser um elemento (de um outro conjunto) e que exista o conjunto vazio (sem elemento, mas que, como tal, pode ser elemento de outro conjunto) - o vazio indica tanto um conjunto, o conjunto vazio, quanto o não conjunto, aquilo que não é idêntico a si —; nesse sentido, o 'zero' denota o vazio que se conta como um conjunto. É partir disso que se pensa o 'ao menos um' lacaniano.

O Um, marcado como o Um de uma falta, como conjunto vazio, participa do princípio da repetição:

\begin{abstract}
A teoria analítica vê despontar o Um em dois de seus níveis. Primeiro nível: o Um é o Um que se repete. Por outro lado, [...] o que se produz no chamado estágio do mais-de-gozar é uma produção significante, a do $S_{1}$. Outro nível do Um [...]. O Um de que se trata no $S_{1}[\ldots]$ é, ao contrário do que se trata na repetição, o Um como Um só [Un seul]. É o Um na medida em que, seja qual for a diferença existente, sejam quais forem todas as diferenças que existem e todas as quais se equivalem, existe apenas uma: é a diferença. (LACAN, 1971-72/2012, p. 159)
\end{abstract}

Existe a diferença radical, e a mesmidade da diferença. O que é diferente de um elemento a outro é sempre a mesma coisa. $\mathrm{O}$ fator que promove a diferenciação de um elemento a outro, ao longo da cadeia, é o mesmo; ele se repete.

"Que o sexo é real, não há a menor dúvida. E sua própria estrutura é o dual, o número dois. O que quer que pensemos, existem apenas dois, os homens e as mulheres" (LACAN, 1971-72/2012, p. 149). A estrutura dual é real, correlata da não relação sexual. Vamos do sentido de caráter de essência, ao sentido sexual enquanto privação de sentido, significação, equívoco e aturdimento (BADIOU; CASSIN, 2010/2013, p. 16). Onde se pregava que a ontologia regulava a linguagem... com Lacan, na linguagem se apresentam efeitos de estrutura motivados pela incidência do real ${ }^{41}$.

Só há dois, 'homem' e 'mulher', mas enquanto ‘zero' e 'um'. Além do mais, acontece que de dois não se faz Um, não há fusão movido por Eros. Lacan propõe um paralelo com a genética. O sexo, na sua vertente de não relação, também se dá a ver nas duas espécies de gametas, espermatozoide e óvulo, dessemelhantes, o que também seria

\footnotetext{
41 "Dizer que faço ontologia, de qualquer modo, é engraçado. E colocá-la nesse grande Outro que mostro como devendo ser barrado, e destacado pelo próprio significante dessa barragem, é curioso" (LACAN, 1971-72/2012, p. 214).
} 
indicativo de uma não relação. "Quando os gametas se juntam, o que resulta não é a fusão dos dois [...]. E aquilo que é um novo, para que isso se faça, é preciso que cada um dos dois tenha largado um certo número de destroços" (LACAN, 1971-72/2012, p. 151), via meiose. Também há um resto.

Se o conjunto dos homens é um conjunto consistente marcado pela incompletude decorrente da perda de um fragmento de gozo, "a lógica da sexualidade feminina não está baseada na incompletude, mas na inconsistência [...] e só pode ser apreciada pela radical diferença e singularidade" (DUNKER, 2016, p. 186) — daí sua experiência de gozo não ser encarada como algo que visaria preencher o que estava em falta (estratégia do homem), mas como um suplemento.

O gozo do Outro, do corpo do outro, é marcado pela infinitude, tal como no paradoxo de Zenão - de Aquiles e a tartaruga — : o passo da tartaruga é cada vez menor, nunca chega ao limite (face real do número). Por outro lado, Aquiles só pode ultrapassá-la, nunca alcançá-la, a não ser no infinito (o limite do número está no infinito). Na empreitada de tratar de homem e mulher a partir do 'zero' e do 'um', Lacan se volta para a noção de 'compacidade' em lógica.

\subsubsection{Para uma compacidade sexual}

Tratemos brevemente da noção de compacidade em topologia geral e do uso que Lacan fez dela - tomamos como base o resumo publicado na edição do Seminário XX da Letra Freudiana, a partir das explicações de Jean-Michel Vappereau. Ao leitor interessado, indicamos seu livro Étoffe: les surfaces topologiques intrinsèques (1988). O que nos interessa é a novidade proposta por Lacan como forma de conceber esse gozo do Outro lado, a partir de um espaço fechado, limitado e compacto, onde se desenrola uma sequência infinita da qual é possível ser extraído algo de finito, um por um, dentro da topologia da reta numérica real $\mathrm{R}$ (cada ponto da reta corresponde a somente um número real).

Isso nos permitirá tratar logicamente termos usados no lacanismo que se relacionam à mulher, como 'não todo', 'gozo Outro' e 'uma-a-uma'.

Partimos das noções de 'limite' e 'continuidade', 'espaço aberto' e 'espaço fechado'. Por exemplo, numa determinada reta, o espaço fechado [0,1] compreende os pontos 0 e 1; já o espaço aberto ]0, 1[ não os compreende. No intervalo fechado [0,1], compacidade, numa primeira definição, diz respeito a recobrir um espaço fechado com 
espaços abertos — "recobrir" aqui tem o sentido corriqueiro, como recobrir o teto de uma casa com telhas. Um espaço é compacto se for possível extrair de todos os recobrimentos abertos, infinitos, um sub-recobrimento finito. "O conjunto desses espaços abertos se oferece sempre a um sub-recobrimento de espaços abertos, todos eles constituindo uma finitude, ou seja, que a sequência dos ditos elementos constitui uma sequência finita" (LACAN, 1972-73/2010, p. 22). Nas palavras de Lacan a respeito da compacidade:

[...] esse mesmo espaço delimitado, fechado, recoberto de conjuntos abertos, isto é, daquilo que se define como excluindo seu limite, do que se define como maior do que um ponto, menor do que um outro, mas em caso algum igual ao ponto de partida nem ao ponto de chegada, para lhes dar uma imagem rápida, o mesmo espaço sendo, pois, suposto recoberto por espaços abertos, é equivalente dizer, isso se demonstra, que o conjunto desses espaços abertos se oferece sempre a um sub-recobrimento de espaços abertos, todos eles constituindo uma finitude, ou seja, que a sequência dos ditos elementos constitui uma sequência finita. (LACAN, 1972-73/2010, pp. 21-2)

Estamos no intervalo [0,1], concebendo seus recobrimentos. Partimos da sequência infinita do tipo ]1/n , 1], ou seja, os recobrimentos ]1/2,1]; ]1/3,1]; ]1/4,1;....; ]1/n,1]. Num intervalo [0, $\Sigma$ [, sendo $\Sigma$ um número entre 0 e 1, onde 'recobrimento' se escreveria assim: $\mathrm{G}=\{] 1 / \mathrm{n}, 1],[0, \Sigma[$ : onde $0<\Sigma<1$ e $n \in \mathrm{N}$, com $n>1\}$.

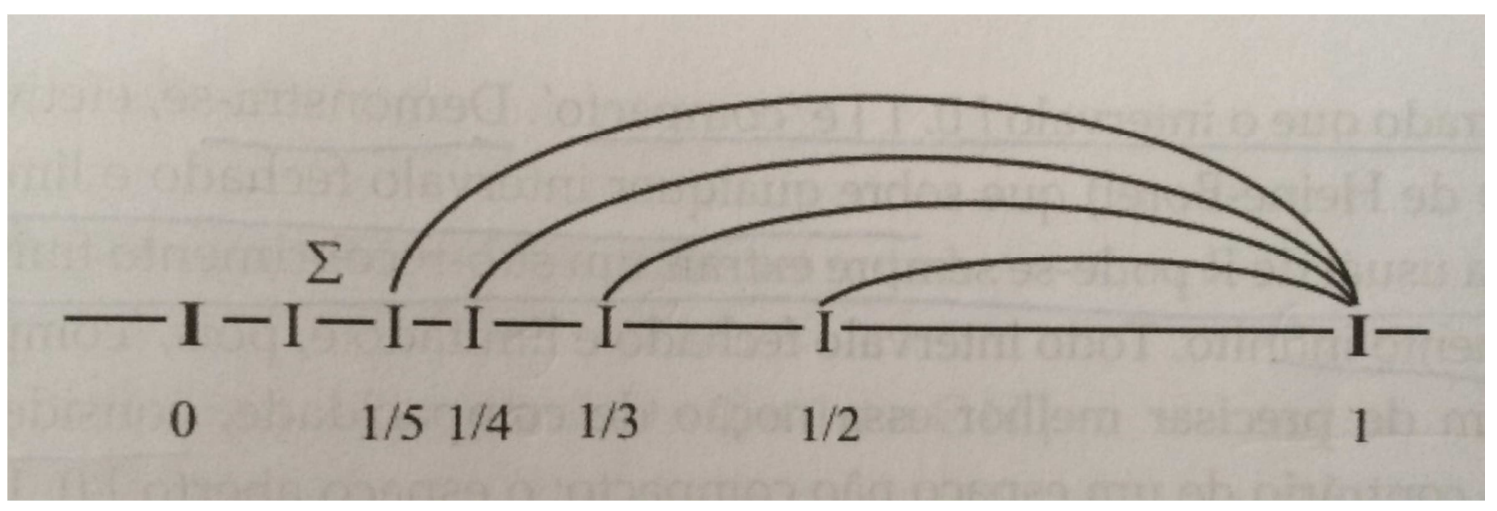

A sequência ]1/n , 1] é infinita - quando $\mathrm{n}$ tende para o infinito, $\mathrm{n}$ tende para o 'zero', sem jamais alcançá-lo. O recobrimento, infinito, só é possível acrescentando o espaço $[0, \Sigma[$ a tal sequência infinita. E um sub-recobrimento finito é possível capturar desse recobrimento infinito $\mathrm{G}$. 
Acabamos, pois, de demonstrar que sobre o intervalo fechado $[0,1]$ podíamos extrair um sub-recobrimento finito de um recobrimento infinito. Se pudermos proceder a essa extração a partir de qualquer recobrimento infinito, teremos demonstrado que o intervalo $[0,1]$ é compacto. (LACAN, 1972-73/2010, p. 30)

Conclui-se que é possível capturar um sub-recobrimento finito de um recobrimento infinito de um intervalo fechado e limitado.

Se partíssemos do contrário, do espaço aberto ]0, 1[, chegaríamos à conclusão de que não se trata de um espaço compacto, pois não é possível a extração de um sub-recobrimento finito a partir do recobrimento infinito.

Também existe a definição de compacidade em termos de fechado, dada pelo próprio Lacan:

Nada mais compacto do que uma falha, se está bem claro que, em algum lugar, está dado que a intersecção de tudo o que aí se fecha sendo admitida como existente, num certo número finito de conjuntos, disso resulta, é uma hipótese, que a intersecção existe num número infinito. Isso é a própria definição de compacidade. (LACAN, 1972$73 / 2010$, p. 20)

Tal definição permitiria admitir que é possível concluir sobre o infinito a partir do finito. Contudo, a nosso ver, o ponto forte desse percurso lacaniano sobre a compacidade é a tentativa de fundamentar topologicamente a ideia de que se pode extrair o finito do infinito. No campo do gozo Outro, relacionado a uma sequência infinita que se dá dentro de um espaço fechado e compacto, pode-se extrair algo de finito; uma a uma, já que estamos na posição feminina no que aponta para um gozo não fálico:

a finitude demonstrável desses espaços abertos [...] capazes de recobrir esse espaço delimitado, fechado, no caso do gozo sexual, o que implica, em todo caso, é que os ditos espaços - e já que se trata do Outro lado, vamos colocá-lo no feminino - podem ser tomados um por um, ou ainda, "uma por uma"'. (LACAN, 1971-72/2012, p. 22)

O ser sexuado da mulher, como não todo, partindo da compacidade do gozo sexual, só pode ser tomado isoladamente, um por um, ao encarnar o Outro, afirma Lacan (1972-73/2010, p. 22). Don Juan toma as mulheres uma a uma; é um desejo feminino: "Ele pode fazer uma lista delas e [...], a partir dos nomes, pode-se contá-las" (LACAN, 1972-73/2010, p. 23). Ao contrário do 'ao menos um', que as toma 
indiscriminadamente - a todas, como sendo uma coisa só - , Don Juan credita especificidade a cada uma.

\subsubsection{Homem e mulher entre zero e um}

A lógica pode ser denominada como a ciência do real, 'real' aqui entendido como o impossível relativo aos impasses lógicos, na medida em que é imanente à ordem simbólica. Esse real aponta para uma inconsistência lógica, mas que deve ser alvo de um constrangimento lógico objetivo - a impossibilidade é logicamente objetiva. E o real pulsional, substância lógica do vivido, encontra sua expressão conceitual mais potente na noção do Um, algo que se conte sem ser.

Frege, filósofo e matemático alemão, questiona como se nomeia a sequência natural dos números inteiros. Nesse contexto, ele se dedica a pontos subjacentes como a natureza do número, o que venha ser o 'zero' e o 'sucessor'. O número aqui não representa uma coleção, não é um conceito empírico. A unidade pode ser referida a um elemento indiferenciado do conjunto, mas também pode ser tomada como nome, como número $u m$ - o número pode portar uma significação nova, não simplesmente se referir à repetição de uma unidade. "Em Frege, o Um pode ser encarado a partir de algumas perspectivas: enquanto número cardinal, enquanto cifra, nome próprio, designando o objeto número Um, como unidade, conceito" (CARDOSO, 2010, pp. 131-2). Nesse processo, Frege vai contra toda a tradição empirista que pressupõe um sujeito psicológico intrínseco às operações ou métodos usados para a construção da identidade do objeto, para se verter a leis puramente lógicas não oriundas da empiria: representações objetivas são desdobradas no que denomina como 'conceito' e 'objeto', que devem ser tomados como equivalentes. O número deve se referir ao 'conceito' e o 'zero' deve contar como um número. Exemplo:

"Vênus possui nenhuma lua". A partir dessa frase, a que atribuir 'nenhuma'? Frege - segundo Yves Duroux, no Seminário XII de Lacan — diz que não se atribui o 'nenhuma' ao objeto lua, já que não há; contudo, a numeração 'zero' é uma numeração. O que é atribuído não é ao objeto 'lua', mas ao conceito 'lua de Vênus'. 'O conceito 'lua de Vênus' é referido a um objeto que é o objeto 'lua' — a relação do conceito 'lua de Vênus' ao objeto lua é tal que não há lua. Daí se atribui ao conceito 'lua de Vênus' o número zero” (DUROUX in LACAN, 1964-65, p. 129). 
Segundo Miller, nesse mesmo Seminário XII, o objeto é definido somente a partir da propriedade que lhe permite cair sob o conceito - estamos longe da empiria —, entrando em jogo a dimensão lógica do conceito que não opera por determinações, mas sim a partir do conceito da identidade a um conceito. Não se trata do objeto 'lua da terra', por exemplo, mas sim do conceito 'idêntico ao conceito lua da terra': "o que cai sob o conceito não é a coisa como tal, mas somente a coisa como uma" (MILLER in LACAN, 1964-65, p. 165) - nesse caso, o objeto que cai sob o conceito passa a ser uma unidade. A coisa é transformada em objeto pela função da identidade na determinação de sua unidade. Passamos da função do agrupamento à função da identidade: "o número como nome não é mais então o nome unificante de uma coleção, mas o nome distintivo de uma unidade" (MILLER in LACAN, 1964-65, p. 166). Assim, o 'um' todo número tem, já que constituído como unidade (o 2 é uma unidade, o 3 é uma unidade etc). Mais uma vez, o x é o objeto que cai sob o conceito idêntico a x (se falamos em x, é porque essa função do 'um' é universalizável); o número um será atribuído a essa coisa tornada objeto nessa transação. E o 'zero' é justamente o número ao qual se atribui o conceito "não idêntico a si ${ }^{42}$.

O número pertence a um conceito. 'Zero' é um número. Partindo da verdade analítica de que cada objeto independente é idêntico a si mesmo, 'zero' é o número que cabe ao conceito 'não idêntico a si mesmo' e nenhum objeto recai sobre esse conceito. Temos então um conceito contraditório cuja extensão é vazia, e o 'zero' se define pela contradição lógica que é a garantia da não existência do objeto. Já “o número 1 é o número que cai sob o conceito de todos os conceitos cujo elemento é o 'zero' (0), assim como 2 é o número atribuído ao conceito de todos os conjuntos equivalentes ao conjunto cujos elementos são 0 e 1, e assim sucessivamente" (CARDOSO, 2010, p. 133). Assim vemos como o 2 , inclusive, pode ter sido encarado por Lacan quando recorre a esse número para se pensar o homem e a mulher: 2 parte do conjunto de zero e Um.

Então o 'zero' designa o conceito de um objeto logicamente impossível, por seu aspecto autocontraditório, ao mesmo tempo em que conta como Um, elemento positivo que participa da sucessão numérica. Esta é a lógica que interessa a Lacan, a que parte de proposições cujo valor lógico é indeterminado e que se furta de soluções

\footnotetext{
${ }^{42}$ Para um maior aprofundamento nesse tema, indicamos o livro O significante, o conjunto e o número a topologia na psicanálise de Jacques Lacan, de Paulo Marcos Rona (2012).
} 
metalinguísticas, preservando seus paradoxos. A que parte da consideração de que a rede simbólica é inconsistente.

E como se daria a sucessão ao 'um' a partir do 'zero'? Pela aparelhagem de dupla contradição. A um deve ser atribuído o conceito 'igual a zero', na medida em que 'zero' "é o objeto que cai sob o conceito de zero ao mesmo tempo que não é igual a zero" (DOUROUX in LACAN, 1964-65, pp. 132-3); na medida em que reitera o vazio no interior de cada extensão - ele é sempre a mesma extensão vazia que está no âmago do avanço na sucessão. O conjunto vazio é repetidamente acrescentado a cada número cardinal, sucessivamente.

O 'um' se concebe a partir do 'zero' tomado como conceito e primeiro objeto. Processo: parte-se do conceito 'idêntico ao conceito de número zero', o objeto que cai sob esse conceito é o objeto 'número zero' e disso se produz o 'um': “Temos o conceito do número zero, e o número zero torna-se objeto para produzir, enfim, o número um” (MILLER in LACAN, 1964-65, p. 168). O 'zero' conta como 'um', e tal propriedade do 'zero' é o que possibilita a série dos números. A fórmula do sucessor é: número atribuído ao conceito 'membro da série dos números naturais terminados por n'. Se partirmos de $\mathrm{n}=3$, por exemplo, segue Miller (in LACAN, 1964-65, p. 169), o número que se pode atribuir a esse conceito é 4 . Conta-se 1, 2, 3 e mais o 0 , levando a 4. Já que o 0 conta como 1 . O 0 , além de ser o número atribuído a um conceito sob o qual nenhum objeto é subsumido, é suporte do 1 - cujo caráter é decisivo para que haja progressão.

O que nos leva a outra consideração: é a mesma inexistência que é reiterada; ela é, ao mesmo tempo, Uma e a Mesma, na medida em que conduz à diferenciação de cada número entre si - na sucessão, o que faz um número diferir do outro é a inserção de um elemento que aponta para uma não diferença, uma diferença idêntica a si mesma. Dois tipos de diferença, então: uma relativa e outra absoluta ou radical. Seria a mesma diferença que se repete ao diferenciar uma mulher da outra? E dois tipos de 'um' em Lacan.

Barros (2012) localiza naquela vertente absoluta da diferença o que denominou como "diferença feminina" ou "alteridade" — diferença não relativista e que não exige oposição de termos. Trata-se, então, de "uma diferença que permita situar a mulher como diferente no absoluto, o que implica que ela é diferente de si mesma; portanto em um plano que excede a comparação, a começar pela comparação com ela própria. Esta seria a diferença feminina [...]" (BARROS, 2012, p. 6). Nas palavras de 
Lacan: "A alteridade do sexo descaracteriza-se por essa alienação. O homem serve aqui de conector para que a mulher se torne esse Outro para ela mesma, como o é para ele. [...] na dialética falocêntrica, ela representa o Outro absoluto" (LACAN, 1960/1998, p. 741).

Se há dois tipos de diferença, há dois tipos de 'um' em Lacan. O primeiro diz respeito a este 'um' como simples sucessor do 'zero', na sucessão dos números inteiros, marcando a diferença relativa entre os números (números esses que, por outro lado, carregam o fato de serem idênticos entre si em sua diferença relativa no interior da série); segundo, o 'um' tido como extensão de um conjunto vazio. "Isto é, a inexistência do resíduo contraditório que se reitera sempre como Um Mesmo Nada" (CARDOSO, 2010, p. 136). É sempre a mesma impossibilidade que se reitera: "é esta mesmidade do Um da inexistência que não cessa de se repetir" (CARDOSO, 2010, p. 138). Temos o ‘um' que se repete, 'um' enumerável, e o ‘um' da inexistência, o ‘um' da falta, no interior da sucessão dos números inteiros: contradição lógica que faz eco, em Lacan - a ordem significante se funda a partir de uma contradição interna à própria ordem simbólica. Porém,

a reiteração da mesmidade como sendo o fundamento dos objetos lógicos não implica de forma alguma sua indiferenciação. Ao contrário, é unicamente na ordem simbólica que, entre as diferenças relativas dos elementos, podemos ver aparecer um tipo inteiramente novo de valor diferencial e que consiste nesta singularidade da diferença enquanto tal. (CARDOSO, 2010, p. 140)

A questão é como transpor isso para a psicanálise no que Miller (in LACAN, 1964-65, p. 163) denomina como a "lógica do significante", para a qual os conceitos são o sujeito e o significante. Para Miller, o progresso da série dos números inteiros só se dá com a função do sujeito, aqui profundamente relacionado ao 'zero'. No empirismo, para que se passe da coleção de unidades para à unidade do número é necessário o sujeito, cuja função pode ser reduzida à nomeação (o número funcionaria como o nome da coleção). O que se concebe aqui por 'sujeito' é o sujeito caracterizado por seus atributos psicológicos, detentor de um poder - é esse tipo de sujeito que Frege quer excluir do campo em que o conceito de número se dá. Miller parece considerar que se trata de um outro sujeito a participar da gênese da série: o sujeito, em psicanálise, é esse 'zero', mas como elemento positivo cujo conceito aponta para a inconsistência do simbólico. 
O que nos importa: o 'zero' é um número, o número deve se referir a um conceito (o objeto é o conceito, e não uma representação objetiva ou subjetiva); o 'zero' é o número que convém ao conceito "não idêntico a si”" ou 'diferente de si mesmo'; a sucessão se estabelece a partir do 'zero' enquanto número, do 'um' que se repete e do 'um' enquanto falta — da diferença relativa à diferença absoluta —; a marca metonímica do objeto $a$ é efeito do 'zero', é um efeito do número; o sujeito se sustenta na série dos números, mas não esse sujeito psicológico que Frege pretendia neutralizar, mas o sujeito do inconsciente. O 'um a menos' da sexuação lacaniana é o 'zero' que conta como 'um'. Tentemos agora levar essa discussão do 'zero' e do 'um' para 'homem' e 'mulher' segundo a interpretação de Récanati presente na versão da Letra Freudiana do Seminário XX de Lacan.

Lado 'homem': trata-se do "existe x que diz 'não"”, o que aponta para um limite. Isso sustenta o universal "para todo x $\Phi$ de x" — é o envolvimento pelo Um o que leva o conjunto a se afirmar quanto à castração. Já na mulher, a posição não é simétrica com relação ao homem frente ao pai. Nada nela diz 'não' à função fálica (não existe $x$ que nega a função fálica), o que leva a pensar que ela está plenamente dentro dessa função, só cabendo a ela o que de suplementar a ultrapassa. A mulher não se situa a partir do limite, mas a partir de outro ponto - no caso, o A. Dessa forma, com relação à função fálica, ela só pode se inscrever como não toda.

A função do pai do lado 'homem', existência necessária, é atrelada a uma alteridade radical fora do terreno coberto pelo $\Phi$. Tal esvaziamento faz com que nenhuma verdade lógica possa ser declarada sobre ela - nada permite avaliar se se trata de verdadeiro ou falso, segundo Récanati. Do outro lado, como a função é mais do que preenchida (ou super saturada), é dada a mesma impossibilidade de analisar em termos de verdadeiro e falso - , mas de maneira não simétrica à do homem. “A disjunção entre os dois é radical. Ambos não estão desligados um do outro, mas ambos estão desligados com relação a $\Phi$, e os dois desligamentos estão, eles próprios, em discordância. De forma alguma, eles são comensuráveis" (RÉCANATI in LACAN, 1972-73/2010, p. 210).

Se, lado homem, o Um é associado ao 'existe um que nega', o 'zero' pode se ligar ao 'todo x é submetido a $\Phi$ ' - o primeiro, Um, necessário, torna o segundo possível a título de 'zero'. Enquanto a mulher, marcada por $\mathbb{A}$, pertencer ao registro do 'não existe x que não $\Phi x$ ', Récanati (in LACAN, 1972-73/2010, p. 210) afirma que "ela 
se situará entre o 'zero’ e o ‘um', entre centro e ausência, e não será mais numerável”, distanciando-se de Lacan quando caracterizou a mulher como enumerável.

HOMEM MULHER

\begin{tabular}{|c|l|}
\hline $\begin{array}{c}\text { Um (existe } x \\
\text { que não) }\end{array}$ & $\begin{array}{l}\text { Zero } \\
\text { existe } \quad x \quad \text { que } \\
\text { não) }\end{array}$ \\
\hline $\begin{array}{c}\text { Zero (todo x } \\
\text { se submente) }\end{array}$ & $\begin{array}{l}\text { Um (não todo } \\
\text { x se submete) }\end{array}$ \\
\hline
\end{tabular}

A mulher, ela não se liga ao Um da forma com que o 'zero' se liga ao Um, sob recusa, tal como se passa do lado homem. Récanati propõe, inversamente à leitura mais difundida, que o "não existe x tal que não $\Phi$ de x" permite a origem do "não todo x $\Phi$ de x". No caso dela, ao contrário do homem, é o "não existe x tal que não $\Phi$ " que se associa ao 'zero', já apontando para uma indeterminação. O 'zero', ou melhor, algo que não seria exatamente 'zero', é tratado antes de sua constituição pelo Um - o 'um' determinaria o 'zero' do lado 'homem'; do lado 'mulher', o contrário. Nesse ponto de vista, é "o não todo x $\Phi$ de x" que desempenha o papel do Um e torna possível certa suplementariedade, "um Um a mais possível” (RÉCANATI in LACAN, 1972-73/2010, p. 211). Contudo, esse Um a mais é indeterminado, já que referenciado à não existência do 'não existe x que não $\Phi$ de x', o que torna seu status uma fantasia.

O 'não todo' está do lado do infinito. Para considerarmos que a afirmação 'não todo x $\Phi$ de x' fosse verdadeira, teríamos de partir do finito, da exceção particular que fundaria o universal. Assim, o 'não todo' da mulher não pode ser deduzido da negação do particular do 'ao menos um', como acontece do lado homem - temos outro regime de existência, fundado a partir da indeterminação.

O homem, tal como "todo x $\Phi$ de $\mathrm{x}$ ", sustenta-se a partir do Um, na alteridade de sua existência. Já do lado da mulher, ela não é e nem se aproxima do Um. Por quê? Porque entre o 'não existe $\mathrm{x}$ que não $\Phi$ de $\mathrm{x}$ ' e 'não todo $\mathrm{x} \Phi$ de $\mathrm{x}$ ' há $\mathrm{o}$ indecidível. Mas não é pelo fato de não ser o Um que isso implica que ela seja o Outro - sua relação é com o A.

Se o 'todo' do homem se deve à essência do Um, na mulher "o 'não toda' é sustentado pelo "não Um"” (RÉCANATI, in LACAN, 1972-73/2010, p. 211). Aqui cabe uma distinção a ser feita: a negação do Um não se dá da mesma forma. De um lado, 
temos a existência necessária do um que funda o conjunto, delimitando o espaço de $\forall x$ ao negar $\Phi x$. Do outro, temos uma inexistência, uma negação da própria existência do Um, o que acaba sustentando esse indecidível que marca a relação da mulher com o A. 


\section{CONCLUSÕES}

Na modernidade que a psicanálise surge, segundo Braidotti (in BRENNAN, 1997, p. 123), operou-se uma mudança histórica a partir da qual a visão clássica de sujeito é abalada e o outro passa a ser signo da diferença, sob a proliferação de múltiplas imagens - o significante 'mulher', como outro absoluto, é então locus dessa crise de valores sustentada pelo masculino. Nesse sentido, a diferença passou a ser sexualizada a ponto de se conceber uma diferença feminina — ou, se há diferença, ela só pode ser feminina; o feminino seria o outro diferente. Contudo, "as orientações específicas que marcam a formulação da questão da diferença sexual na teoria feminista estão sendo sistematicamente apagadas na corrente do pensamento convencional pós-moderno e desconstrutivo sobre a diferença sexual" (BRAIDOTTI in BRENNAN, 1997, p. 124). $\mathrm{Da}$ mulher enquanto sujeito empírico se foi na direção do gênero, entidade dessexualizada - acompanhamos todo o esforço de Irigaray em defender a importância para o feminismo de preservar a diferença.

Este ponto é essencial, é o que distingue a psicanálise dos estudos de gênero. [...] Não há cena psíquica de um homossexual, homem ou mulher, onde o outro sexo não se imponha em sua presença, sua exigência, seja ela por imitação, pela penetração anal, na posição papai-mamãe ou com um pênis artificial. (ANDRÉ, 2016, p. 6)

A alteridade do outro sexo sempre se pronuncia - o inconsciente ignora a igualdade. Na perspectiva de André, Zizek e Copjec, clamar pela multiplicação dos gêneros é um projeto político interessante, mas que pode levar ao afogamento da diferença e do que se entende por sexo em psicanálise, justamente o que não pode ser abarcado pela díade sexo biológico - gênero - "não é uma questão moral, é uma questão de método" (ANDRÉ, 2016, p. 7). Nessa perspectiva, segundo Saez:

A diferença fundamental e irredutível entre o queer e a psicanálise é que o queer faz uma leitura das práticas sexuais não normativas como forma de resistência simbólica e política, nunca como posições subjetivas de origem psicológica ou psicanalítica, nem como estruturas do desejo. (SAEZ, 2004, p. 193; trad. nossa).

Se se dá ênfase ao sexo em seus aspectos de construção sociocultural e se foca o dispositivo da sexualidade foucaltiano, a diferença sexual é entendida como pretexto que cria sistemas de gênero heterocentrados e binários do sexo. Por outro lado, 
a psicanálise se volta aos três registros, ao inconsciente e proclama que não há relação sexual.

Acompanhamos a denúncia de Butler de que o Édipo tem função normativa, permitindo ao sujeito assumir seu sexo. Ao homem cabe a virilidade; à mulher, um tipo feminino - enunciado problemático de Lacan. O Édipo implanta a diferença sexual e a identificação com seu gênero correspondente. Podemos entender aqui que Lacan opera binariamente: dois sexos, dois gêneros. Essa forma de pensar tem consequências clínicas importantes - a não correspondência entre sexo e gênero é sinal de patologia, critério esse adotado por Stoller frente ao sujeito transexual.

Em outro contexto, no Édipo lacaniano - abordado a partir dos elementos da linguagem — o falo, significante primordial, decreta duas posições: "ser o falo" se refere à posição feminina; "ter o falo", à masculina. Mais críticas a Lacan: ter eleito o falo como o único ou o principal organizador da sexualidade, sendo que a ideia de falo sempre se articula à figura do pênis, para alguns; ter prescrito, mais uma vez, somente duas possibilidades (homem e mulher) às quais se acoplariam somente dois predicados possíveis - ser o falo ou ter o falo no plano simbólico. Daí muitas feministas considerarem que o simbólico lacaniano decreta a diferença sexual aos moldes heterossexuais. Não só esse desenvolvimento teórico de Lacan mantém a binaridade como, segundo Butler, incorreria no erro de querer definir homem e mulher, atribuindo a eles status ontológico - deslize este também de Stoller, ao perseguir incansavelmente o "núcleo de identidade de gênero". Nessa perspectiva, a psicanálise então confirmaria a heteronormatividade vigente: dois sexos, dois gêneros como um ideal a ser atingindo.

Nos anos 70, na vanguarda do lacanismo, as fórmulas da sexuação apresentam o lado 'homem' e o lado 'mulher', o que, para alguns, ratificaria aquele condenado binarismo hierarquizante.

\footnotetext{
Assim, cabe a pergunta: em que medida as fórmulas da sexuação não descreveriam uma forma específica de subjetivação que tem como paradigma o desejo masculino em uma sociedade que se estrutura a partir das relações de dominação entre os gêneros, onde a mulher não é considerada sujeito? (ARÁN, 2009, p. 662)
}

Mas se há dois lados nas fórmulas da sexuação, pensamos que a relação entre eles não é dicotômica.

Segundo Elizabeth Grosz (1989), dicotomia é o sistema em que dois elementos existem um em oposição a outro, ou seja, um sistema construído a partir de 
termos binários ou pares de opostos mutuamente exclusivos e mutuamente exaustivos. Por exemplo, só há A e não-A; se não se é A, necessariamente se é não-A — a relação entre esses elementos se dá a partir do princípio da não contradição. Nesse caso, um termo é positivamente definido e o outro é o seu negativo, sem contorno próprio, ao passo que serve para delimitar positivamente o primeiro. Como diz Grosz (1989, p. xvi): “dicotomias são não reversíveis, estabelecem uma relação de hierarquia não recíproca e prescrevem sistemas de dominação". Nesses termos, há o homem e a mulher como não-homem.

E o que podemos entender por 'diferença'? A diferença não privilegia um termo e define o outro como seu contrário, tal como se procede com as oposições binárias; além disso, não se reduz a dois elementos, pois outros podem ser admitidos. "Onde dicotomias partem de A/não-A, diferenças assumem a forma de relações A/B" (GROSZ, 1989, p. xvii). Ou seja, essa concepção da diferença é interessante para se pensar a diferença sexual por nos levar para fora do binarismo. Não estamos nos pautando no princípio da não contradição, mas numa forma de diferenciar que não implique subordinação de um termo pelo outro - o que faz rever a proposta de Wittig quanto à urgência da anulação do sexo para que a política do sexual seja reinventada.

Assim, se em psicanálise se rejeita a ideia de um sujeito sexualmente neutro — ao se proclamar a diferença dos sexos —, isso não quer dizer que se concorda com a lógica binária que rege normativamente homem e mulher e que estabelece uma relação hierárquica entre eles, assim como se dá no terreno dos gêneros. Haveria outra maneira de se conceber a relação entre homem e mulher sem ser aquela prescrita pelo modelo heterossexual que se pauta na ideia de complementariedade entre os sexos. Percorremos a sexuação lacaniana nesse ponto, ao se munir da teoria dos números, dos conjuntos e de todo seu arsenal lógico: como não há representação de homem e mulher no inconsciente, entra-se no universo dos semblantes - conceito, a nosso ver, muito próximo da performance de gênero butleriano e da mimesis de Irigaray. As fórmulas da sexuação apresentam duas experiências de gozo incomensuráveis; e, na sua parte inferior, escrevem-se os parceiros fantasísticos não recíprocos de homem e mulher não há relação sexual.

"Diferença dos sexos" em Lacan retoma aquela antiga tradição de tratar de homem e mulher focando a relação assimétrica que se estabelece entre eles. A teoria lacaniana evidenciou, desde o começo, o desencontro e a disparidade: seja na posição 
assumida frente à falta e à estratégia de desejo, seja no que se estende às duas lógicas incompatíveis frente à função fálica e ao Um.

A teoria da sexuação é marcada pelo não todo e, como tal, seria no mínimo um contrassenso considerar que ela pretenderia dizer tudo sobre sexo e o que compete a 'homem' e 'mulher'. Ela nem mesmo possibilita uma leitura unívoca sobre suas próprias prerrogativas: acaso tratar-se-ia da pretensão de conceber um sujeito masculino e um sujeito feminino; posições rotativas de gozo, assim com seriam as dos discursos; identificações; diferentes maneiras de se capturar a fala? A interpretação sobre o estatuto da sexuação define o tipo de contribuição a ser oferecida aos estudos de gênero. Para nós, ela não se sustenta na biologia dos corpos, não prescreve gênero nem quais práticas sexuais devem ser legitimadas - a sexuação consagra a indeterminação no coração do sexo. Sobretudo, a nosso ver, revela que a relação sexual falha, e falha de duas maneiras distintas e inconciliáveis.

Outro aforismo de destaque é "A mulher não existe", que tendeu, para alguns, a ser encarado como uma forma renovada de afirmar a inferiorização da mulher; já para outros, no que compete à edificação de identidades, tal declaração lacaniana é a que verificamos ser a mais elogiada no que se presta à desidentificação, como vimos com Cornell e Saez. Enquanto entidade negativa, a mulher escapa ao imaginário ocidental que a engessa.

Wittig quer decretar o fim do gênero. A sexuação se verte ao gozo.

[...] sua capacidade subversiva se evidencia em que Lacan não teoriza a sexualidade em termos de gênero, e sim em termos de gozo. Se um dos esforços principais da teoria queer é pensar a sexualidade fora das categorias de gênero, aqui temos um exemplo desse tipo de pensamento. (SAEZ, 2004, p. 184; trad. nossa)

A sexuação lacaniana apoiaria um tipo de feminismo ou de teoria queer antigênero? A relação entre gozo e gênero nos parece ser um vasto campo de pesquisa.

A teoria da sexuação não é uma teoria essencialista que visa decretar o que homens e mulher são, mas como se relacionam com a função fálica e o gozo, com o semblante e a fantasia. A diferença com que homens e mulheres lidam com esses elementos faz com que a relação sexual entre eles seja impossível. Se nos anos 50-60 'ser o falo' e 'ter o falo' poderiam ser entendidos como essências de 'mulher' e 'homem' - o que permitiria estabelecer uma relação —, na sexuação o gozo fálico impede a relação sexual, impede que o homem chegue à mulher: "esse tópico da 
necessária impotência fálica, que aparece ao logo do Seminário XX, está de acordo com a análise feminista a respeito do funcionamento e deficiências do falocentrismo" (GALLOP, 1982, p. 34).

Grosso modo, Lacan quer tratar dos sexos em sua incomensurabilidade: "assim, com Lacan, lembremos, não se trata, ao reconhecer a diferença dos sexos, de fazer da psicanálise a guardiã das normas de gênero, mas de sobretudo sublinhar o que separa os seres sexuados apesar de todos os encontros sexuais e amorosos" (LEGUIL, 2015, p. 67) - "entre o homem e a mulher há um mundo" (LACAN, 1972/2011, p. 90).

Contudo, há outro nível de problema. A questão, para Braidotti (in BRENNAN, 1997), é como tornar essa diferença de sexos um lugar de enunciação, e mesmo como tratar da mulher feminista enquanto mulher que comporta um excesso disruptivo e que excede as premissas falogocêntricas - como pensar a identidade da mulher feminista levando em conta o a-mais da mulher? É aí que as discordâncias se tornam mais evidentes.

Por mais que fique impressionada com a argumentação dos críticos lacanianos da lógica do falogocentrismo, estou convencida de que o desafio conceitual do feminismo é radicalmente diferente do projeto da psicanálise. Ele tem a ver com a dimensão epistemológica mencionada acima: como articular a 'diferença dentro' de cada mulher com a prática política que exige a mediação das 'diferenças entre' as mulheres, de modo que represente e implemente a diferença sexual. Dentro do feminismo, a questão político-epistemológica de conseguir transformações estruturais do sujeito não pode ser dissociada da necessidade de efetuar mudanças nos referencias sociomateriais, o que é um dos pontos de divergência entre as 'cenas' feminista e psicanalítica. (BRAIDOTTI in BRENNAN, 1997, p. 132)

Se à corrente do feminismo psicanalítico francês - como vimos com o movimento da escrita feminina de Cixous e Montrelay e com o texto semiótico de Kristeva - interessava dirigir-se a um lacanismo que fornecesse os substratos da linguagem a auxiliar na construção de uma experiência literária inovadora a ponto de ser capaz de abalar a ordem social falogocêntrica e o patriarcado, ainda segundo Braidotti, a psicanálise, mesmo trazendo elementos importantes para uma compreensão mais afiada a respeito da diferença sexual,

pouco ou nada fez para mudar as condições sociais concretas das relações de sexo e de estratificação do gênero. Esta última é precisamente o alvo da prática feminista; o feminismo não trata da sexualidade feminina nem do desejo - ele tem a ver com mudança. 
Essa é a mais importante diferença individual que existe entre os movimentos psicanalítico e feminista: a definição de mudança e como proceder para efetuá-la. A psicanálise e o feminismo parecem abordar a questão da transformação política a partir de ângulos radicalmente diferentes e extremamente incompatíveis. (BRAIDOTTI in BRENNAN, 1997, p. 135)

Mas Gallop pensa diferente: "a psicanálise, por exemplo, pode desestabilizar a tendência feminista de aceitar um eu tradicional, unificado, racional, puritano - um eu supostamente desprovido da violência do desejo. O feminismo pode estremecer a tendência psicanalítica de se pensar apolítica (GALLOP, 1982, p. xii). A primeira sentença foi a aposta de Mitchell.

Lacan diz que as pulsões são sempre parciais, elas se encontram tanto nos meninos quanto nas meninas e nada dizem a respeito da diferença sexual. Além do mais, como sustenta Mitchell (1985), a sexualidade humana, a ser assunto do inconsciente, não pode ser equacionada à genitalidade — a pulsão não é enquadrável em nenhuma norma: "há normas sociais, na falta de qualquer norma sexual" (LACAN, 1973-74, p.6).

Ragland-Sullivan enxerga o serviço que o lacanismo poderia prestar:

Para entender a contribuição de Lacan ao feminismo, deve-se considerar que ele lê Freud tendo revelado uma lógica do inconsciente que toca o Real, cujo axioma fundamental é: a cultura deriva do fato de que não há relação sexual, nenhum significante adequado para representar a diferença dos sexos. Com esta teoria, a mudança feminista proposta deve ir do projeto de luta contra as opressões sexistas sustentadas em conceitos totalizantes como gênero e patriarcado em direção aos impasses do Real e da satisfação pulsional. (RAGLAND-SULLIVAN, 1992, p. 206)

Se o feminismo escancara conceitos problemáticos da teoria psicanalítica como 'falo' e 'registro simbólico' —, traz à luz as edificações políticas de suas instituições, assim como obriga os psicanalistas a se posicionarem de outra forma no meio social, para além das quatro paredes do consultório. Já o real lacaniano e as consequências de enunciados como 'Não há a relação sexual' ou 'A mulher não existe' poderiam colaborar com o projeto feminista. Além do mais, há o corpo, nem todo biológico nem meramente construído socialmente - superfície libidinal onde um campo de forças é posto em operação. Preciado segue a empreitada de restituir através da tecnologia o que não seria performatizável no gênero, a dimensão corporal. Em 
outros termos, o corpo pulsional da psicanálise, reconhecido mais tarde por Butler - e que se põe como terreno às experiências de gozo — , é outro ponto comum de interesse.

Kirsten Campbell enxerga outra utilidade da psicanálise para o feminismo: o discurso psicanalítico serviria para a revisão da epistemologia feminista.

Campbell propõe relocar Lacan para dentro do campo da epistemologia feminista e se volta para a teoria dos discursos: "sem esta reconfiguração, a epistemologia lacaniana permanece fora da política feminista" (CAMPBELL, 2004, p. 27) - essa seria uma forma do lacanismo contribuir para a prática social. Se, para a autora, o domínio discursivo da cultura ocidental se dá sob a forma do discurso do mestre, a configurar um saber masculino, a teoria feminista não escaparia a isso. Para que renovadas posições de enunciação epistemológicas possam ser concebidas, diferentes posições discursivas devem ser ocupadas: "eu sugiro que a teoria lacaniana oferece à epistemologia feminista um modelo para uma prática transformadora a partir da descrição de seu discurso analítico" (CAMPBELL, 2004, p. 106), o que talvez permita falar em num novo discurso, "discurso feminista", que não se preste a representações totalizadas, mas que incorpore a contingência que impossibilita fixações identitárias, ou mesmo funde um novo contrato social, uma nova ordem sóciosimbólica, segundo Campbell (2004, p. 4).

Ainda na perspectiva da prática, se o debate entre feminismo e psicanálise é antes de tudo teórico, ele não deixa de ter um eco clínico. "Qual psicanálise permitiria lidar com os "gêneros não inteligíveis" de maneira não "patologizante"”? (KNUDSEN, 2007, p. 147). Pensamos que a sexuação lacaniana, como orientação clínica que dá destaque ao real, nos auxilia nisso.

Suas fórmulas apontam que o discurso ou as normas do Outro declinam frente o campo do gozo no terreno do sexual, cabendo a tais normas somente fornecer as bases para a edificação dos semblantes fálicos, "aparecências" de homem e mulher. Escolha de gozo também não tem nada a ver com escolha de objeto e estamos longe do padrão edipiano da heterossexualidade; gênero, anatomia ou prática sexual não são critérios a determinar onde o sujeito se localizará nas tábuas da sexuação. Além do que — e insistimos muito nesta tese - elas não apresentam aquele famigerado ranço do binarismo sexual. Daí se considerar uma clínica que adotasse como referência a sexuação lacaniana, furtando-se a rótulos que estigmatizam as múltiplas expressões da sexualidade como desviantes - ao operar a lógica do não todo e sua indecidibilidade e imprevisibilidade intrínsecas. 
Se a cultura patriarcalista tende a negativizar a mulher e a prescrever relações de dominação entre os gêneros, assim como a sua inteligibilidade, não consideramos que as fórmulas sejam uma tradução, via lógica, desse cenário. Como já defendemos, as fórmulas da sexuação revelam preferencialmente a estrutura do funcionamento lógico presente no aforismo "A relação sexual não existe", e não aquela que rege o cenário das relações de poder dadas historicamente entre os gêneros. Se, como afirmou repetidas vezes Lacan, as fórmulas da sexuação são uma tentativa de escrever a não relação sexual, é o discurso psicanalítico que aqui entra em cena.

Por fim, gostaríamos agora de insinuar novos caminhos de pesquisa: homem e mulher podem ser pensados também a partir do amor, do saber a da teoria dos nós. Se no Seminário XXI, Lacan (1973-74, p. 39) segue afirmando que "essa função que faria a relação, essa função do homem em relação à mulher, essa função da mulher em relação ao homem...não existe o que possa se escrever", e que o dizer verdadeiro é a "ranhura" por onde passa a ausência decorrente da impossibilidade de escrever a relação sexual - como a prática do discurso psicanalítico demonstra - tal ranhura não é vazia, passa-se algo ali. Às vezes, "entre dois sujeitos", passa-se "alguma coisa que lembra uma relação, alguma coisa cessa de não se escrever, para alguns casos raros e privilegiados" (LACAN, 1973-74, p. 50): o amor viria suprir a verdade da relação sexual. Nesse sentido, Badiou afirma, a respeito da não relação sexual: "frente à insuficiência dessa situação, uma suplementação se faz necessária, não por uma terceira posição estrutural, mas por um evento singular - esse evento inicia o processo amoroso: chamemo-lo de encontro" (BADIOU in SALECL, 2000, p. 267). E mais adiante: “A diferença sexual só é concebível ao se lançar mão do amor como um critério diferenciador" (BADIOU in SALECL, 2000, p. 279). O amor diferenciaria homem e mulher. Naquele mesmo Seminário XXI, na aula de 12 de fevereiro, Lacan afirma que o amor do homem vai sem dizer, já lhe ele é embebido em gozo, ao passo que o da mulher não vai sem dizer, sem o dizer da verdade.

No Seminário XXI, Lacan inclui outro modelo aos seus desenvolvimentos, a teoria dos nós, e recorre a ele ao tratar do homem, da mulher e do saber.

o saber masculino, no ser falante, é irremediavelmente unário, um corte dando início a um fechamento [...] esse saber masculino, no ser falante, é o elo de barbante. Ele gira em volta. Nele há o Um de saída, como traço que se repete - aliás, sem se contar —; e, de girar em torno, ele se fecha, sem mesmo saber que, desses elos, há três. Como ele pode, como podemos nós supor que ele chega a conhecer um fim 
dessa distinção elementar? Bom, felizmente para isso há uma mulher. Eu já lhes disse que a mulher [...] "A mulher não existe", mas uma mulher, isso, isso pode se produzir quando há um nó, ou trança. (LACAN, 1973-74, p. 44; trad. nossa)

Anuncia-se que o aforismo "Não há relação sexual” também será tratado a partir dos nós: "especialmente por não se escrever jamais a relação sexual em si mesma, senão na falta de seu desejo, a qual não é nada senão seu aperto no nó borromeano" (LACAN, 1973-74, p. 45). E à frente: "eu me coloco a questão, que relação há entre o nó borromeano e aquilo que enunciei das quatro [fórmulas da sexuação]... eu diria opções, ditas de identificação sexuada" (LACAN, 1973-74, p. 94).

Já no Seminário XXIII Lacan continua abordando 'homem' e 'mulher' a partir da não relação entre eles, recorrendo ainda a outro prisma: se o mulher é o sinthoma do homem, “ há necessidade de encontrar um outro nome para o que o homem é para uma mulher, posto que o sinthoma se caracteriza justamente pela não equivalência" (LACAN, 1975-76/2007, p. 98), o que Lacan vai denominar como 'devastação'. A não relação lacaniana tem vida longa. 


\section{REFERÊNCIAS}

AGACINSKI, S. (2012) Femmes entre sex et genre. Paris: Seuil.

AMBRA, P. (2015) O que é um homem - psicanálise e história da masculinidade no Ocidente. São Paulo: Annablume editora.

ANDRÉ, S. (2016) “Que gênero de sexo?" Conferência proferida em Sociedade Brasileira de Psicanálise - São Paulo.

ARÁN, M. (2009) A psicanálise e o dispositivo da diferença sexual, Revista de estudos feministas. Florianópolis, 17(3): 312, setembro-dezembro/2009, pp. 653-673.

AYOUCH, T. (2014) A diferença entre os sexos na teorização psicanalítica: aporias e desconstruções, Revista Brasileira de Psicanálise, vol. 48, n. 4, 58-70, 2014.

BADIOU, A.; CASSIN, B. (2010) Não há relação sexual: duas lições sobre o "Aturdito" de Lacan. Rio de Janeiro: Zahar, 2013.

BARNARD, S.; FINK, B. [Org.] (2002) Reading seminar XX: Lacan's major work on love, knowledge and feminine sexuality. EUA: State University of New York Press.

BARROS, R. R. (2012). Da diferença sexual à diferença feminina. Opção Lacaniana online nova série. Ano 3, número 9, novembro.

BEAUVOIR, S. (1949) O segundo sexo - fatos e mitos, $4^{\text {a }}$ ed. São Paulo: Difusão europeia do livro, 1970.

BENHABIB, S [et.al] (1995). Feminist contentions: a philosophical exchange. New York/London: Routledge.

BERENI, L.; TRACHMAN, M. (2014) Le genre, theories et controversies. Paris: Presses Universitaires de France.

BRENNAN, T. [Org.] (1997) Para além do falo: uma crítica a Lacan do ponto de vista da mulher. Rio de Janeiro: Record / Rosa dos tempos.

BROUSSE, M-H. (1991) Feminism with Lacan. NFF spring/fall, vol. 5, nn. 1-2, pp. 123-136.

BUTLER J. (1987) Subjects of Desire: Hegelian Reflections in Twentieth-Century France. New York: Columbia.

(1990) Problemas de gênero - feminismo e subversão da identidade. Rio de Janeiro: Editora Civilização Brasileira, 2003.

(1993) Cuerpos que importan. Sobre los límites materiales y discursivos del «sexo». Buenos Aires: Paidós, 2010. 
(1997) The psychic life of power: theories in subjection. California: Stanford University Press.

(2000) Antigone's claim: kinship between life and death. Nova York: Columbia University Press.

. (2004) Undoing gender. Nova York/Londres: Routledge.

BUTLER, J; LACLAU, E.; ZIZEK, S. (2000) Contingency, Hegemony, Universality: Contemporary Dialogues on the Left. Londres/Nova York: Verso.

CALVET, L-J. (2012). Lacan e a escrita Chinesa: um inconsciente estruturado como escrita?, Alea : Estudos Neolatinos, 14(2), 245-259. Disponível em: <https://dx.doi.org/10.1590/S1517-106X2012000200007>.

CAMPBELL, K. (2001) The Plague of the Subject: Psychoanalysis and Judith Butler's, Psychic Life of Power. International Journal of Sexuality and Gender Studies, vol. 6, Nos. 1/2, 200, pp. 35-48.

Routledge.

(2004) Jacques Lacan and feminist epistemology. Londres/Nova York:

CARDOSO, M. J. E. (2010) Lacan e Frege: sobre o conceito de Um, Revista Psicologia USP, São Paulo, janeiro/março, 2010, 21(1), pp. 127-144.

CIXOUS, H. (1975) "The laught of the Medusa". In: MARKS, E.; DE COURTIVRON, I. New french feminism. USA: Schocken Books, 1981.

. (1975). The newly born woman. Theory and history of literature (Book 24). University Of Minnesota Press, 1986.

(1979). Vivre l'orange. Des femmes: Paris

COPJEC, J. (1994) Read my desire_Lacan against the historicists. Cambridge MA/ Londres: MIT Press.

(2002) Imagine there's no woman: ethics and sublimation. Cambridge MA: The MIT Press.

. (2012) The sexual compact, Angelaki: journal of theoretical humanities, vol. 17, n. 2, jun. 2012. Nova York/Londres: Routledge - Taylor \&Francis Group.

COSSI, R. K. (2011) Corpo em obra: contribuições para a clínica psicanalítico do transexualismo. São Paulo : nVersos editora.

DAVID-MÉNARD, M. (1998) As construções do universal: psicanálise e filosofia. Rio de Janeiro: Companhia de Freud. 
[Org.] (2009) Sexualités, genres et mélancolie: s'entretenir avec Judith Butler. Paris: Édtions Campagne Première

DUNKER, C.I.L. (2008), Véu, semblante e mascarada - o teatro histérico e o cinema feminino. São Paulo [capturado em 16 de junho de 2008]; Disponível em: <http://stoa.usp.br/chrisdunker/files/1872/10607/2008+-

$+\mathrm{V} \% \mathrm{C} 3 \% \mathrm{~A} 9 \mathrm{u}+$ Semblante+e+Mascarada+-

+ Ana+Luc\%C3\%ADlia+Rodrigues+\%28pref\%C3\%A1cio\%29.pdf>.

. (2011) Estrutura e constituição da clínica psicanalítica: uma arqueologia das práticas de cura, psicoterapia e tratamento. São Paulo: Annablume.

(2016) Por que Lacan? São Paulo: Zagodoni.

FAJNWAKS \& LEGUIL, C.(org.) (2015). Subversion lacanienne des theories $d u$ genre. Paris: Éditions Michèle.

FARIA, M. R. (2013) Castração. Publicado por Lalíngua no Caderno de Reuniões Clínicas: III Seminário Clínico. Ribeirão Preto, SP, 23 de novembro de 2013.

(2015) Do significante da falta à falta de significante: A dimensão da causa no fundamento do desejo e do objeto na passagem do Seminário 8 ao Seminário 9, Stylus (Rio de Janeiro), (31), 63-70. Recuperado em 01 de novembro de 2016, de $<$ http://pepsic.bvsalud.org/scielo.php?script=sci_arttext\&pid=S1676$\underline{157 X 2015000200007 \& \operatorname{lng}=\mathrm{pt} \& \ln \mathrm{l}=\mathrm{pt}>}$.

FERRAZ, F. C. (2001) A erotização do ódio na perversão (resenha de Robert J. Stoller Perversion: the erotic form of hatred). Recuperado em: <http://revistapercurso.uol.com.br/pdfs/p26_leitura06.pdf $>$.

FINK, B. (1998) O sujeito lacaniano: entre a linguagem e o gozo. Rio de Janeiro: Jorge Zahar Ed.

FLAX, J. (1990). Psicoanálisis y feminismo : pensamientos fragmentarios. Madrid: Ediciones Cátedra, 1995.

FOUCAULT, M. (1976) História da sexualidade I: A vontade de saber. Rio de Janeiro: Edições Graal, 1988.

FRAISSE, G. (2010). À côté du genre : sexe et philosophie de l'égalité. Lormont : Le bord de l'eau.

FREUD, S. (1905) "Três ensaios sobre a teoria da sexualidade". In: Obras completas, vol. 7. Rio de Janerio: Imago, 1997.

- (1925) "Algumas consequências psíquicas da diferença anatômica entre os sexos”. In: Obras completas, vol. 16. São Paulo: Companhia das Letras, 2011.

(1931) "Sexualidade feminina”. In: Obras completas, vol. 18. São Paulo: Companhia das letras, 2010. 
FROSH, S. (1994) Sexual Difference: Masculinity and Psychoanalysis. Londres-Nova York: Routledge.

FUENTES, M. J. S. (2009), As mulheres e seus nomes: Lacan e o feminino. Tese de doutorado, Instituto de Psicologia da Universidade de São Paulo.

GABRIEL, A. B. (2009) A casa da diferença: feminismo e diferença sexual na filosofia de Luce Irigaray. Dissertação de mestrado, Universidade de Brasília.

GALLOP, J. (1982). The daughter's seduction - feminism and psychoanalysis. Ithaca: Cornell University Press.

(1985) Reading Lacan. Ithaca: Cornell University Press.

GEERTS, E. (2010-11). Luce Irigaray: the (un)dutiful daughter of psychoanalysis - a feminist 'moving through and beyond' the phallogocentric discourse of psychoanalysis. Recuperado em: 〈http://philpapers.org/rec/GEELIT>.

GROSZ, E. (1989). Sexual subversions: three french feminists. Austrália: Allen \& Unwin.

IRIGARAY, L. (1973) Le langage des déments. Paris: Mouton / De Gruyter.

(1974) Speculum of the other woman. Ithaca: Cornell University Press, 1985. [Publicação original: Speculum: de l'autre femme. Paris: Les éditions de Minuit].

(1977) The sex which is not one. Ithaca: Cornell University Press, 1985. [Publicação original: Ce sex qui n'en est pas un. Paris: Les éditions de Minuit].

(1984) An ethics of sexual difference. Ithaca: Cornell University Press, 1993. [Publicação original: Éthique de la différence sexuelle. Paris: Les éditions de Minuit].

IVES, K. (2013). Cixous, Irigatay, Kristeva: the jouissance of the french feminism. USA: Crescent Moon Publishing.

KNUDSEN, P. P. P. S. (2007). Gênero, psicanálise e Judith Butler: do transexualismo à política. Tese de doutorado, Instituto de Psicologia da Universidade de São Paulo.

KRISTEVA, J. (1969) Séméiôtiké: recherches pour une sémanalyse. Paris: Edition du Seuil. 1984.

(1974) Revolution in poetic language. Nova York: Columbia Press Univesity, (1977) Polylogue. Paris: Edition du Seuil.

(1979) “Women's time”. In: MOI, T. [Ed.] The Kristeva reader. New York: Columbia University Press, 1986.

. (1980). Pouvoirs de l'horreur: essai sur l'abjection. Paris: Éditions du Seuil. 
(1981) "Oscilation between power and denial". In: MARKS, E.; DE COURTIVRON, I. New French Feminism. USA: Schocken Books, 1981.

LACAN, J. (1949). "O estádio do espelho como formador da função do eu”. In: Os escritos. Rio de Janeiro: Jorge Zahar, 1998.

1988.

(1955-56) O seminário, livro 3 - as psicoses. Rio de Janeiro: Jorge Zahar Ed.,

(1957) "Instância da letra no inconsciente ou a razão desde Freud". In: Os escritos. Rio de Janeiro: Jorge Zahar, 1998.

(1957-58) O seminário, livro 5 - as formações do inconsciente. Rio de Janeiro: Jorge Zahar Ed., 1999. 1998.

(1958) “A significação do falo". In: Os escritos. Rio de Janeiro: Jorge Zahar,

(1959-60) “Observação sobre o relatório de Daniel Lagache: 'Psicanálise e estrutura da personalidade"”. In: Os escritos. Rio de Janeiro: Jorge Zahar, 1998.

(1960) "Diretrizes para um congresso da sexualidade feminina". In: Os escritos. Rio de Janeiro: Jorge Zahar, 1998.

2005.

. (1962-63). O seminário, livro 10 - a angústia. Rio de Janeiro: Jorge Zahar Ed.,

(1964) O seminário, livro 11 - os quatro conceitos fundamentais da psicanálise. Rio de Janeiro, Jorge Zahar Ed., 1998.

(1964-65). Problemas cruciais para a psicanálise. Publicação não comercial centro de estudos freudianos do Recife.

(1971) O seminário, livro 18 - de um discurso que não fosse semblante. Rio de Janeiro: Jorge Zahar Ed., 2009.

. (1971). Estou falando com as paredes: conversas na Capela de Sainte-Anne. Rio de Janeiro: Jorge Zahar Ed., 2011

2012.

(1971-72) O seminário, livro 19 - ...ou pior. Rio de Janeiro: Jorge Zahar Ed.,

(1971-72) Le séminaire, livre XIX - Ou pire...[Versão Staferla].

(1972-73) Encore. Versão Escola da letra freudiana. Rio de Janeiro, 2010.

. (1973) “O aturdito”. In: Outros Escritos. Rio de Janeiro: Jorge Zahar, 2003.

(1973-74) Le séminaire, livre XXI - Le non dupes errent [Versão Staferla]. 
.(1973-74) "Interview de Jacques Lacan sur France Culture à l'occasion du $28^{\text {ème }}$ congrès international de la psychanalyse". In: Le coq-Héron $\mathrm{n}^{\circ} 46-$ 47, Paris, 1974, pp.3-8. Recuperado em http://espace.freud.pagesproorange.fr/topos/psycha/psysem/fcultu.htm

2007. . (1975-76) O seminário, livro 23 - o sinthoma. Rio de Janeiro: Jorge Zahar Ed., (1976-77) Le séminaire, livre XXIV - L' insu que sait de l'une-bévue s'aile à mourre [Versão Stafela].

LAGO, M. C. de S. (2010) "A psicanálise nas ondas dos feminismos". In: Diversidades: dimensões de gênero e sexualidade. Ilha de Santa Catarina: Ed. Mulheres.

LAQUEUR, T. W. (2001) Inventando o sexo: corpo e gênero dos gregos a Freud. Rio de Janeiro: Relume Dumará.

LE GAUFEY, G. (2007) El notodo de Lacan: consistencia lógica, consecuencias clínicas. Buenos Aires: El cuenco de plata.

LEGUIL, C. (2015). L'être et le genre - homme/femme après Lacan. Paris: Presses Universitaires de France.

LEVET, B. (2014). La théorie du genre ou le mode rêvé des anges - l'identité sexuée como malédiction. Paris: Bernard Grasset.

MITCHELL, J. (1974) Psychoanalysis and feminism: a radical reassessment of Freudian psychoanalysis. Nova York: Pantheon Book.

MITCHELL, J.; ROSE, J. (1985) Feminie Sexuality: Jacques Lacan and the école freudienne. Nova York/Londres: Norton and Pantheon Books.

MONTRELAY, M. (1977) L'ombre et le nom : sur la feminité. Paris: Ed. De Minuit.

NUSINOVICI, V. (2008) Notas sobre o semblant. Recuperado em: <www.tempofreudiano.com.br/artigos/detalhe.asp?cod=81>.

MOREL, G. (2000). Ambiguités sexuelles - sexuation et psychose. Paris: Ed. Anthropos.

PORCHAT, P. (2015) Um corpo para Judith Butler, Periódicus: revista de estudos indisciplinares em gêneros e sexualidades, Salvador, n. 3, v. 1, mai.-out. 2015, pp. 3751 .

PRECIADO, B. (2002). Manifiesto contra-sexual - prácticas subversivas de identidad sexual. Madrid : Editorial Opera Prima.

RABINOVICH, D. (1995). A significação do falo - uma leitura. Rio de Janeiro: Companhia de Freud. 
RAGLAND-SULLIVAN, E. (2004) The logic of sexuation: from Aristotle to Lacan. Albany: Sunny University of New York Press.

RONA, P. M. (2012) O significante, o conjunto e o número - a topologia na psicanálise de Jacques Lacan. São Paulo: Annablume

RODRIGUES, C. (2012). Antígona: lei do singular, lei no singular, Sapere Aude, v. 3, n. 5. Belo Horizonte.

ROUDINESCO, E (1994). História da psicanálise na França. Rio de Janeiro: Zahar.

ROUDINESCO, E.; PLON, M. (1998). Dicionário de psicanálise. Rio de Janeiro: Jorge Zahar Ed.

ROTH, M. (2000) Freud: conflito e cultura: ensaios sobre sua vida, obra e legado. Rio de Janeiro: Jorge Zahar.

RUBIN, G. (1975) The traffic in women: notes on the "political economy" of sex. Recuperado em: <https://genderstudiesgroupdu.files.wordpress.com/2014/08/therraffic-in-women.pdf $>$.

(2003) Tráfico sexual - entrevista, Cadernos Pagu (21): pp. 157-209. Recuperado em: 〈www.scielo.br/pdf/cpa/n21/n21a08.pdf $>$.

SALIH, S. (2013) Judith Butler e a Teoria Queer. Autêntica Editora: Belo Horizonte.

SAEZ, J. (2004). Teoría queer y psicoanalisis. Madrid: Editorial Sintesis.

SALECL, R. (org.) (2000) Sexuation. Durham/Londres: Duke University Press.

SAFOUAN, M. (2009) Le langage ordinaire et la difference sexuelle. Paris: Odile Jacob.

SHEPHERDSON, C. (2000) Vital signs: nature, culture, psychoanalysis. Nova York: Routledge.

SOLER, C. (2005) O que Lacan dizia das mulheres. Rio de Janeiro: Jorge Zahar Ed.

STOLLER, R. J. (1982) A experiência transexual. Rio de Janeiro: Imago.

(1968) Sex and gender: the development of masculinity and feminility. Londres:

Karnac Books, 1984.

Artes Médicas.

(1993) Masculinidade e feminilidade: apresentação de gênero. Porto Alegre: . (1998) Observando a imaginação erótica. Rio de Janeiro: Imago Ed. 
VAPPEREAU, J-M. (1988) Étoffe: les surfaces topologiques intrinsèques. Paris: Topologie en extension.

WHITFORD, M. (1997) "Releitura de Irigaray". In: BRENNAN, T. [Org.] Para além do falo: uma crítica a Lacan do ponto de vista da mulher. Rio de Janeiro: Record / Rosa dos Tempos.

. (1991) The Irigaray reader. Malden/Oxford: Blackwell Publishers Ltda.

WITTIG, M (1964). L'Opoponax. Paris: Union générale d'éditions. (1971) Les guérillères. New York: Viking Press. (1992) The straight mind and other essays. Boston: Beacon Press books.

WRIGHT, E. [Ed.] (1992) Feminism and psychoanalysis - a critical dictionary. USA: Blackwell Ltd.

Publishers.

(2000) Lacan and the postfeminism. USA - UK: Icon Books/ Blackwell

ZIZEK, S. (1995) Woman is one of the names-of-the-father. Disponível em: <www.lacan.com/zizwoman.htm>.

. (1999). The ticklish subject: the absent centre of political ontology. Londres/Nova York: Verso.

ZUPANCIC, A. (2012). Sexual difference and ontology, E-flux journal \# 32. 